BEATRIZ EVRARD

\title{
Espaço em movimento: cenografia e circo
}

\author{
MESTRADO EM ARTES CÊNICAS
}

DEPARTAMENTO DE PÓS-GRADUAÇÃO EM ARTES CÊNICAS ESCOLA DE COMUNICAÇÃO E ARTES (ECA)

UNIVERSIDADE DE SÃO PAULO

$$
\text { SÃO PAULO - } 2017
$$




\section{Espaço em movimento: cenografia e circo}

Dissertação apresentada à Banca Examinadora do Departamento de Pós-Graduação em Artes Cênicas da Escola de Comunicação e Artes da Universidade de São Paulo, como exigência parcial para obtenção do título de Mestre em Artes Cênicas, sob a orientação do Professor Doutor Fausto Roberto Poço Viana. 
BANCA EXAMINADORA 
Dedico este trabalho a minha família, que se formou $e$ se constituiu concomitantemente à elaboração desta pesquisa. Dedico este trabalho, que fala de circo e de amor, ao meu amado companheiro Daniel e a nossa pequena filha Clarice, que formam a minha tão sonhada trupe da vida. Obrigada pela paciência e companheirismo, obrigada pela inspiração. 


\section{AGRADECIMENTOS}

As pessoas que passaram pela minha vida, deixaram marcas, paixões, inspirações e amores profundos são inúmeras, e certamente agradeço a todos que me inspiraram de alguma forma.

Aos meus pais Francisca e Franklin pelo amor incondicional, pela força e ajuda inexplicáveis.

Ao Professor Doutor Fausto Roberto Poço Viana, por me guiar nos mares e descobertas desta pesquisa.

E aos meus amados companheiros de palco, os ícaros de nome e alma: Marco Vettore, Erica Rodrigues, Leticia Doretto, Celso Reeks, Álvaro Barcellos e Roberto Haartner, pelos lindos e inspiradores anos de voos e suspensões.

A todos os mais sinceros e amorosos agradecimentos. 


\section{RESUMO}

EVRARD, Beatriz. Espaço em movimento: cenografia e circo. 2016. 161 p. Dissertação (Mestrado em Artes Cênicas) - Escola de Comunicação e Artes da Universidade de São Paulo, São Paulo, 2016.

Este trabalho investiga o espaço da cena onde há a presença de elementos aéreos do circo e ilustra, por meio da trajetória e das criações de uma das primeiras companhias cênicas circenses na cidade de São Paulo, o que é um espaço em movimento. Um breve resgate da história das artes do circo, com ênfase na suspensão dos corpos e nas acrobacias aéreas, é desenvolvido para abordar as questões sobre os desenhos e formas específicas e circenses de habitar o espaço da cena. Uma escritura no espaço tridimensional, que é constantemente modificada pela relação do movimento dos corpos no ar, é exemplificada através do histórico da Companhia Cênica Nau de Ícaros. Um olhar íntimo da pesquisadora, a imersão em diversos espetáculos dessa Companhia e a gênese do espetáculo Tirando os pés do chão descrevem uma forma peculiar de ocupar a cena e desvendam os caminhos de um espaço da cena que sofre influência direta do movimento gerado pelos atores-performers e pela cenografia específica circense.

Palavras-chaves: Espaço da cena. Artes do circo. Suspensão. Cenografia. Movimento. 


\begin{abstract}
EVRARD, Beatriz. Space in motion: scenography and circus. 2016. 161 p. Dissertation (Master Degree in Performing Art) - Escola de Comunicação e Artes da Universidade de São Paulo, São Paulo, 2016.

This work investigates the space of the scene where there is the presence of aerial elements of the circus and illustrates, through the trajectory and creations of one of the first circus performing companies in the city of São Paulo, what is a space in movement. A brief rescue of the circus arts history, with emphasis on body suspension and aerial acrobatics, is developed to address questions about the specific circus designs and ways of inhabiting the scene space. A writing in three-dimensional space, which is constantly modified by the relation of the motion of bodies in the air, is exemplified through the history of the Scenic Company Nau de Ícaros. An intimate look of the researcher, the immersion in several spectacles of this Company and the genesis of the spectacle Taking the feet off the floor describes a peculiar way of occupying the scene and unveils the paths of a space of the scene that undergoes direct influence of the movement generated by the actors-performers and the specific circus scenography.
\end{abstract}

Keywords: Space of the scene. Circus arts. Suspension. Scenography. Movement. 


\section{LISTA DE ILUSTRAÇÕES}

Figura 1 - Circus Maximus (50 a.C.).

Figura 2 - Figura acrobática.

Figura 3 - Performance de saltimbancos realizando número de icários.

Figura 4 - Le bon genre (Paris, 1816).

Figura 5 - La célèbre hollandaise (ilustração de Mauron Delin).

Figura 6 - Família Les Caroli. Número equestre de piramide humaine.

Figura 7 - Cartaz de divulgação do Astley’s Royal Amphitheatre (1850).

Figura 8 - Jules Léotard (1850).

Figura 9 - Cartaz Descente d'Absalon par Miss Stena (1890).

Figura 10 - Cartaz Female trapeze acrobats at circus (1890).

Figura 11 - Cartaz Downie Bros Aerialists (1931).

Figura 12 - Cartaz de Lilian Leitzel (1929).

Figura 13 - Cartaz Os Codonas de J. Pöhm (1925).

Figura 14 - Isabelle Vaudelle no espetáculo Quidam do Cirque du Soleil.

Figura 15 - Reportagem sobre grupos que trabalham elementos de circo.

Figura 16 - Quadro La caída de Ícaro (1636-1638) de Jan Carel van Eyck.

Figura 17 - Cena do espetáculo Nau de Ícaros.

Figura 18 - Cena do espetáculo $O$ pallácio não acorda: atores Marco Vettore, Erica Stoppel e Juliana Neves.

Figura 19 - Apresentação em balão, São João Nepomuceno, MG.

Figura 20 - Cartaz Jupiter the balloon horse do Barnum \& Bailey Circus (1909).

Figura 21 - Reportagem sobre o Galpão Nau de Ícaros.

Figura 22 - Espetáculo-festa.

Figura 23 - Espetáculo Quase uma... 
Figura 24 - Os atores-acrobatas Alex Marinho e Erica Rodrigues, como Pietro e Lina.

Figura 25 - Passarela de concreto e ator em deslocamento suspenso.

Figura 26 - Descida da Igreja Matriz de Bragança Paulista.

Figura 27 - Espetáculo El grand circo carnaval na $1^{\text {a }}$ Virada Cultural, no Vale do Anhangabaú, São Paulo, 2005.

Figura 28 - Espetáculo $O$ CirCo: cena da velha.

Figura 29 - Espaço da cena com imagem projetada à frente dos atores.

Figura 30 - Cena de Don Icário suspenso.

Figura 31 - Cena do espetáculo E agora...: Leticia Doretto na perna-de-pau, Beatriz Evrard dentro da Gota no tecido acima à direita e Erica Rodrigues no chão.

Figura 32 - Cena dos Eixos, suspensões com equipamentos de alpinismo.

Figura 33 - Cena do trapézio duplo.

Figura 34 - Estrutura cenográfica do espetáculo Cidade dos sonhos.

Figura 35 - Espetáculo Cidade dos sonhos.

Figura 36 - Espetáculo De um lugar para o outro.

Figura 37 - Espetáculo De um lugar para o outro: uso de cordas de alpinismo.

Figura 38 - Espetáculo De um lugar para o outro: uso de pernas de pau.

Figura 39 - Espetáculo De um lugar para o outro: projeção e acrobacia aérea.

Figura 40 - Cena final do espetáculo Menor que o mundo.

Figura 41 - Casa da cenografia do espetáculo Menor que o mundo.

Figura 42 - Cena do espetáculo Menor que o mundo, com todos os atores no espaço da cena.

Figura 43 - Entrevista realizada entre os integrantes e amigos da Companhia.

Figura 44 - Flyer do espetáculo Tirando os pés do chão.

Figura 45 - Entrevista, suspensão do entrevistado, gesto do entrevistado impresso no corpo do ator-performer e gesto observado durante ação performática. 
Figura 46 - Gestos obtidos através das entrevistas sendo imprimidos pelo portô no volante.

Figura 47 - Gestos e movimentos obtidos durante as entrevistas.

Figura 48 - Primeira ação performática na unidade Pinheiros do Sesc São Paulo.

Figura 49 - Relação triangular durante entrevista realizada na unidade Santana do Sesc São Paulo.

Figura 50 - Movimento criado a partir do gesto de colocar a mão nos cílios, obtido em entrevista durante a "ação performática".

Figura 51 - Entrevistas como lugar de interação e espaço da cena.

Figura 52 - Gesto, entrevista e improvisação a partir do gesto replicado durante a ação performática.

Figura 53 - Suspensão de um espectador participante durante a ação performática.

Figura 54 - Gestos de entrevistas das ações performáticas do projeto Tirando os pés do chão.

Figura 55 - Espetáculo Tirando os pés do chão: cena dos eixos ou fantoche na corda.

Figura 56 - Cena em que portô carrega o volante no espetáculo Tirando os pés do chão.

Figura 57 - Cena em que se misturam elementos de dança e acrobacia no espetáculo Tirando os pés do chão.

Figura 58 - Cena inicial do espetáculo Tirando os pés do chão.

Figura 59 - Exercício e improvisação Fantoche.

Figura 60 - Ligth painting da cena da lira e da cena dos eixos.

Figura 61 - Suspensão no espetáculo Tirando os pés do chão.

Figura 62 - Cena utilizando o aparelho aéreo lira e projeções de margaridas ao fundo.

Figura 63 - Cena do espetáculo Tirando os pés do chão.

Figura 64 - Disposição espacial das cadeiras no espetáculo Tirando os pés do chão.

Figura 65 - Computador e mesa de som ao fundo da cena, disposta na lateral do palco. 
Figura 66 - Contrarregragem revelada durante cena do espetáculo Tirando os pés do chão.

Figura 67 - Cena utilizando trapézios no espetáculo Tirando os pés do chão.

Figura 68 - Cena utilizando lira no espetáculo Tirando os pés do chão. 


\section{SUMÁRIO}

INTRODUÇÃO

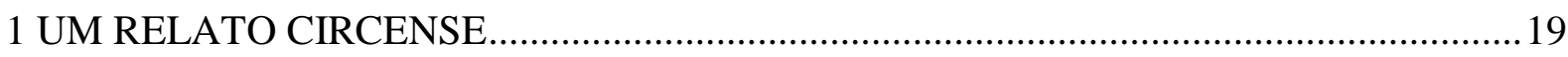

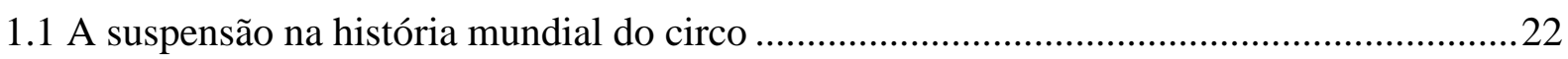

2 COMPANHIA CÊNICA NAU DE ÍCAROS: HISTÓRIAS DE DESENHOS

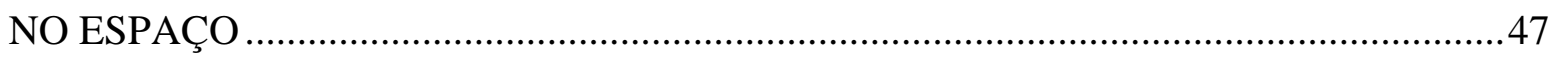

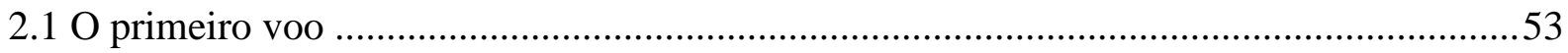

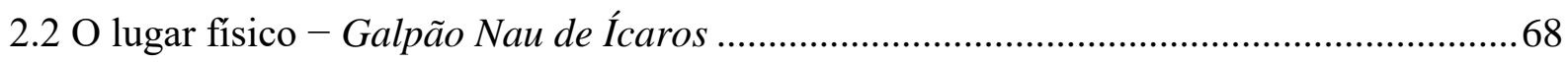

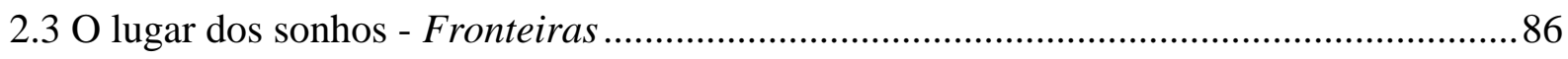

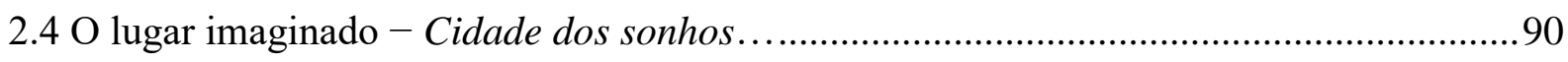

2.5 O lugar do sagrado - De um lugar para o outro............................................................. 92

2.6 O lugar no mundo - Menor que o mundo...................................................................96

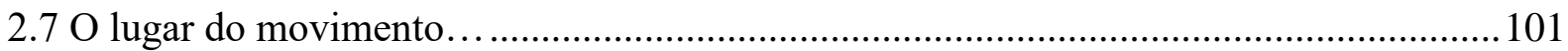

\section{O LUGAR DO AMOR - GÊNESE DO ESPETÁCULO}

TIRANDO OS PÉS DO CHÃO.

3.1 Nelson Rodrigues coloca que o amor é eterno. E que o verdadeiro amor só acontece

uma vez na vida. Você concorda? O amor e a realidade de Myrna ..................................104

3.2 Você gostaria de participar de uma entrevista sobre o amor?

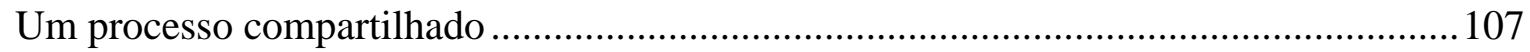

3.3 Onde você sente o amor fisicamente no seu corpo? As ações performáticas ...................112

3.3.1 O amor faz a gente perder a cabeça? Ele cega ou esclarece? As entrevistas ...............114

3.3.2 Você acha o amor físico, emocional, racional ou irracional?

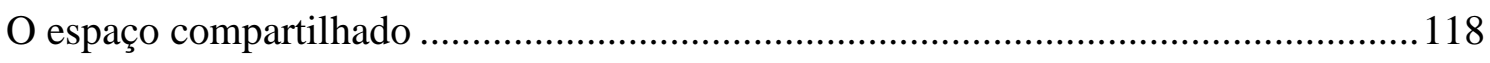

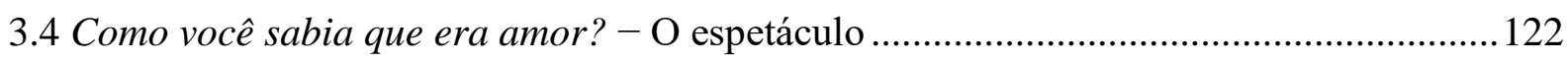

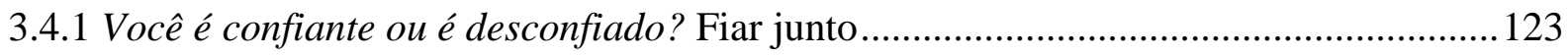

3.4.2 Somos todos fantoches não escolhemos nem certo nem errado porque simplesmente não escolhemos... o que você acha? O espaço em movimento .....................................125

3.4.3 Você conduz, ou é conduzido? Uma cenografia em movimento..................................131

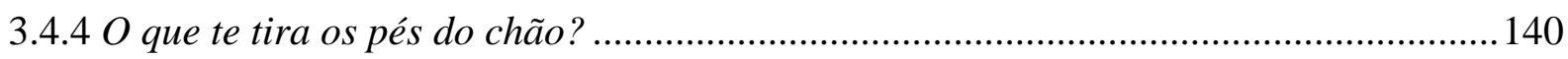


CONCLUSÃO.

REFERÊNCIAS

ANEXO 1 - FICHAS TÉCNICAS

ANEXO 2 - ENTREVISTA TIRANDO OS PÉS DO CHÃO

161 


\section{INTRODUÇÃO}

Falar sobre circo é transitar por diversos espaços e compreensões do que é a palavra circo. Além de um lugar físico, pode remeter a técnicas corporais, a um modo de vida e a uma forma de estar no espaço. Os territórios nos quais o circo transita, e aos quais daremos destaque aqui, são imagens que giram em torno desse universo e estão relacionadas a liberdade, superação e sublimação, tanto objetivas, no que se refere aos corpos que habitam o ar, como subjetivas, relativas aos diversos símbolos e signos que o circo carrega.

Pode se dizer que uma pesquisa circense, assim como a história do circo, se constrói por meio do conhecimento aliado à prática, e desde os primórdios das artes cênicas em geral se sustenta no movimento dos corpos e no deslocamento das trupes nômades. Os artistas que hoje inovam a cena traçam maneiras particulares de nela estar, e aqui destacaremos algumas companhias e pessoas que utilizam elementos aéreos do circo como forma de expressão. A presença dos elementos aéreos do circo pode ser considerada um diferencial, ou um ponto de escape para o trivial e o comum, a busca de algo novo, ou simplesmente uma maneira de alcançar o inalcançável e de preencher o espaço vazio no ar.

Como parte do estudo sobre a presença dos elementos aéreos do circo no espaço da cena brasileira, iremos evidenciar a história particular de uma trupe de marinheiros circenses: a Companhia Cênica Nau de Ícaros.

Mas quem são os ícaros? Um grupo de pessoas que buscam atingir o sol com a ajuda de uma asa feita de penas e cera? Ou um grupo de artistas que através do conhecimento, na metáfora do sol, dão sentido para a vida, como se a única forma de estar vivo fosse rompendo os limites da cena?

Assim como no mito de Ícaro, os artistas aqui descritos se suspendem em direção ao sol, extrapolam os seus conhecimentos e caminham para uma possível sublimação da cena. Saltam, levantam, caem, e novamente se levantam, em um movimento cíclico que já dura mais de vinte e cinco anos. Como artistas de circo, levam suas vidas para o picadeiro e o picadeiro para as suas vidas. Como dançarinos e atores, almejam a sutileza e transmitem nos seus espetáculos uma sucessão de intenções, um rastro no espaço, criado e ampliado pelo circo, diante de um universo de novas possibilidades. 
$\mathrm{Na}$ forma de um relato histórico-pessoal, os acontecimentos aqui apresentados se misturam também com um relato artístico pessoal. $\mathrm{Eu}$, como artista cênica e circense, farei alguns comentários relacionados à minha experiência dentro desse universo. Podemos também definir essas "intervenções" como uma forma de viver uma história já narrada, ou uma ousadia artística pesquisada, na qual a pergunta que norteia esta narração seria: $\mathrm{O}$ que tira os nossos pés do chão?

Essa pergunta foi vivida e pesquisada durante o processo de criação do espetáculo de dança cênico-circense, o Tirando os pés do chão, durante a minha permanência nos doze anos em que estive na Companhia Cênica Nau de Ícaros. Ouso dizer que, como artista circense, minha história com o circo começou de forma inconsciente, assim que tirei os pés do chão pela primeira vez.

Os elementos aéreos do circo e os corpos dos atores-performers, assim como todos os elementos dramáticos presente no espaço da cena, serão tratados nesta pesquisa como materialidades da cena. $\mathrm{O}$ termo materialidades, utilizado por Hans Ulrich Gumbrecht ${ }^{1}$, foi emprestado e nos possibilitou agrupar em uma mesma expressão todos os elementos que estão presentes no lugar onde a cena acontece, sejam eles objetivos ou subjetivos. Segundo o autor, o termo materialidades da comunicação surgiu como tema do Colóquio de Dubrovnik (Croácia) de $1985^{2}$, e foi criado para sanar a necessidade teórica de dialogar sobre as humanidades como "uma cultura mais despida de descrições complexas tal como víamos nas ciências". E, no colóquio de 1988, o termo foi definido como "todos os fenômenos e condições que contribuem para a produção de sentido, sem serem eles mesmos sentidos" (GUMBRECHT, 2010, p. 27 e 28). O autor ainda expõe que os frutos das materialidades de comunicação podem ser descritos como "produção de presença" e que o efeito palpável

\footnotetext{
${ }^{1}$ Nasceu em Wuerzburg, na Alemanha, em 1948. É professor de literatura na Universidade de Stanford. Publicou no Brasil, entre outros livros, Modernização dos sentidos (1998, Editora 34) e Em 1926: vivendo no limite do tempo (1999, Record). (Disponível em: <http://www.companhiadasletras.com.br/autor.php?codigo=02449>. Acesso em: 19 out. 2014).

${ }^{2}$ Os Colóquios de Dubrovnik, aconteceram entre 1981 e 1989, num total de cinco encontros. Tiveram o intuito de redinamizar as teorias e uma possível reforma dos pensamentos das Humanidades e causaram um grande impacto nessa geração de humanistas alemães. Os três primeiros Colóquios apresentaram o princípio de que era possível aprender verdadeiramente com o passado, de que as disciplinas acadêmicas eram em grande parte centradas em estudos literários e linguísticos, mas, segundo Hans Ulrich Gumbrecht, os resultados foram decepcionantes, por serem ligadas a uma história passada muito diferente da presente na época, não apresentando sugestões de mudanças significativas em termos de convenções e práticas. No Colóquio de 1985, foi proposto o tema "materialidades da comunicação", abandonando os títulos tradicionais ligados estritamente aos estudos literários. Ambos os conceitos, de materialidade e comunicação, pareciam fugir da "perpetuidade da interpretaçã o" e serem diferentes dos conceitos do passado (GUMBRECHT, 2010, p. 27).
} 
(espacial) surgido com os meios de comunicação está sujeito, no espaço, a movimentos de maior ou menor proximidade e de maior ou menor intensidade. Qualquer forma de comunicação, com seus elementos materiais, implica uma sensibilização (de modo específico e variado) dos corpos das pessoas que estão em comunicação (GUMBRECHT, 2010, p. 38).

Nesse caminho, a expressão materialidades da cena surge para descrever os conteúdos e formas de imaginação provenientes do pensamento humano, as expressões presentes no conjunto de materiais pelos quais os conteúdos e formas se manifestam no espaço e as formas expressivas criadas pelas imagens desenhadas na cena.

No primeiro capítulo será apresentado um histórico das suspensões dentro do caminho percorrido pelas artes do circo, no intuito de identificar o risco iminente ao se desafiar no limite a gravidade. As nuances dos corpos ocupando um espaço social, que se torna espaço da cena, aparece desde a primeira imagem de uma pessoa fora do chão, no ar.

No momento que se estabeleceu uma cena que associava a suspensão dos corpos em uma relação espetacular, a ação de tirar os pés do chão criou um encantamento, em razão do qual as pessoas inevitavelmente param seu percurso para olhar. Nesse caminho identificamos a relação do "ser observado" e "observar", que faz emergir o sentido das ações dos artistas cênicos que utilizam elementos aéreos do circo em suas criações.

Os primeiros artistas que estabeleceram uma relação de suspensão, os espaços físicos utilizados e criados em função do desenvolvimento das artes do circo, bem como os documentos, estudos e pesquisas, apresentam as inovações técnicas e cênicas que acompanharam a diversas gerações de artistas circenses, que aqui são apresentados na forma relacional entre espaço e corpo, entre movimento e cenografia.

A conexão com a sociedade e a forma como o circo foi se constituindo criaram espaços de encantamento e suspensão de realidades e, ao mesmo tempo escancaram uma existência física e visceral, através da superação dos limites corporais, volatilizada nos desenhos dos corpos no espaço aéreo e na sublimação do corpo como meio de comunicação.

Os sentimentos mais básicos do ser humano, como o medo, a alegria e a superação fazem parte do universo circense e são palavras que se assemelham ao próprio significado das artes do circo. É uma arte cênica que comenta, desafia e questiona o próprio espaço da cena, através das ações e suspensões. A história aqui relatada apresenta modos de ação criados, 
movimentos inventados, cenografias e tecnologias desenvolvidas e, mais do que isso, diversos espaços desafiados e desvendados.

No segundo capitulo, o histórico de uma das primeiras companhias cênicas circenses da cidade de São Paulo será contado através de um olhar íntimo, pelos movimentos impressos no corpo, e pela forma peculiar de habitar o espaço. No ano de 1992, no Circo Escola Picadeiro, em um momento de ebulição das artes cênicas como forma de cruzamento de diversas linguagens artísticas, surgiu a Companhia Cênica Nau de Ícaros.

A apreciação dos caminhos dessa companhia se mistura com as suspensões da cena. A exploração dos diversos espaços e níveis permite que os elementos do circo ampliem os espaços episódicos subjetivos e objetivos, e suscita uma forma específica de habitar e desenhar o espaço da cena.

A primeira vez que assisti à Companhia Cênica Nau de Ícaros foi em 1993, em uma apresentação em uma quadra poliesportiva, no Esporte Clube Banespa. Eu fui descobrir, algum tempo depois, que havia assistido ao espetáculo Sob o céu, quando vi algumas fotos e reconheci os figurinos e os movimentos que ficaram marcados na minha retina e na minha memória, e que me encantaram. Foi surpreendente retomar aquela memória, que parecia esquecida em algum lugar, numa caixinha escrita: "Guarde estas lembranças, pois isso será algo importante na sua vida, isso será uma das formas de você mostrar que está no mundo". O reconhecimento de um espaço, dos corpos e das materialidades que me marcaram impulsionou não só a maneira como meu corpo habita o espaço, como também o meu olhar como artista e pesquisadora da forma como a Companhia surgiu e se desenvolveu.

No terceiro capitulo, a construção da gênese do espetáculo Tirando os pés do chão completa este estudo sobre movimento, cenografia circense, espaço da cena e suspensão.

A escolha de descrever de forma profunda cada etapa de criação do espetáculo surge como resposta de uma pesquisa de anos, em que as materialidades da cena são construídas pela Companhia e por todas as pessoas que tiveram contato com o trabalho. Os caminhos escolhidos e a construção de um espaço interno e externo da cena narra a dilatação de um processo de criação compartilhado com o público. Revela a utilização dos elementos aéreos do circo e a constituição de cenografias que se fundem com os corpos em movimentos, contaminando quem observa e quem é observado. 
As palavras e ideias aqui apresentadas vão além da demonstração de particularidades ou atributos que possibilitam uma relação, indagam sobre estar no espaço, planar no ar, existir na cena, construir uma superfície dinâmica, dialogar com o vazio e desenhar um lugar chamado cena. Mais do que isso, descreve uma paixão que envolve as artes do circo e que, me parece pessoalmente ser inevitável para se estabelecer uma cena em que tamanho risco cênico e físico pode ser comparado à aventura de amar. 


\section{UM RELATO CIRCENSE}

O universo circense, a percepção do espaço, as técnicas e aparelhos aéreos, as cenografias que se confundem com o corpo e a ampliação da relação corpo-espaço-circo se apresentam no percurso da história do circo como parte constituinte desses caminhos. O breve resgate dessa história, com ênfase na suspensão e nas acrobacias aéreas, nos levará aos caminhos de como as artes do circo se desenvolveram e desenharam características marcantes. Apontar, por meio desse histórico, o papel dos elementos aéreos e discutir sobre “estar no ar" dentro do espaço da cena nos permitirá destacar a importância dos movimentos de desenhos criados pelas acrobacias aéreas, aprofundar e compreender uma forma específica e circense de habitar o espaço da cena.

Veremos indicações históricas de princípios do circo, em que a suspensão identifica caminhos, artistas, modalidades circenses, público encantado, risco eminente, ou seja, características e materialidades ${ }^{3}$ que o circo historicamente produziu e cria uma fascinação própria a ele. Há de se destacar também os momentos em que o teatro, a dança e o circo transitaram um através do outro, como artes cênicas capazes de elevar, física e metaforicamente, quem produz e quem contempla.

Assim sendo, apresentamos uma pergunta que norteia esse compêndio histórico: Quais são os pontos importantes desta história que podem ser destacados, diante das suspensões do circo/e no circo como arte viva, em constante movimento?

Os estudos específicos sobre performances aéreas apresentam descrições mais específicas após a invenção do trapézio em 1859 por Jules Léotard (1838-1870), que detalharemos mais à frente neste capítulo. Anteriormente a isso, há na história do circo vestígios de que a possibilidade de romper limites corporais e verticais fazia parte dos rumos que as artes do circo iriam trilhar.

A relação com o voar pode ser observada desde os primeiros indícios das artes do circo: no princípio, os acrobatas em números terrestres já demonstravam uma nítida fascinação por tirar os pés do chão. As mudanças relacionadas aos elementos aéreos também influenciaram a arquitetura circense e, conforme as destrezas aéreas foram se estruturando,

\footnotetext{
${ }^{3} \mathrm{O}$ termo materialidades será discutido na Introdução.
} 
aliadas às tecnologias desenvolvidas, os números e elementos aéreos foram ganhando um espaço definitivo e representativo dentro das artes do circo. Para Rosemberg (2004, p. 25):

[...] nas várias tentativas de registrar o circo, está claro que ele não nasceu nas formas que conhecemos hoje nem como as de ontem. Como qualquer arte, é (des)construída e enriquecida através das formas de expressão nas quais ela mesma evolui $[\ldots . .]^{4}$

O circo, ao longo da sua história, foi se diversificando de tal modo que, dentre as inúmeras pesquisas sobre o tema, encontramos muitos nomes e tipos de circo: circo tradicional, circo de cavalinhos, circo moderno, o circo-teatro, novo circo, circo contemporâneo, circo de variedade, circo de pantomimas, circo pavilhão, entre outros, cada um possuindo características próprias e pontos em comum, mas todos, em uníssono, desenhando a mesma arte. Um dos fatores que torna a pesquisa do caminho percorrido pelo circo relevante é o fato de que muito dessa história, assim como os modos de realizá-lo, durante longo tempo foi transmitido oralmente, dentro das famílias circenses, portanto carrega características que têm a tendência de se modificar ou se (des)construir, assim como a própria arte.

A expressão artes do circo (ROSEMBERG, 2004), mais do que compreender todos estes "tipos" de circo, universaliza o que muitos estudiosos relatam como uma arte múltipla. Ela se aproxima muito do conceito de obra de arte total idealizada por Richard Wagner (1813-1883) em 1848, que indicou características de uma arte atual, que envolve artistas de várias disciplinas, que percorre muitos lugares, que cria e transforma os espaços por onde habita.

A própria história do circo narra a criação e o envolvimento de diversos artistas de modalidades diferentes. A formação de artistas múltiplos se consolidou ao longo desse percurso e companhias cênicas que retratam essa multiplicidade surgiram, se encantaram e se inspiraram nas origens e artes do circo.

$\mathrm{Na}$ minha história como circense, numa tentativa de identificar qual foi o meu momento de encantamento com o circo. Questionei-me em que lugar eu estava quando o circo entrou dentro de mim.

\footnotetext{
${ }^{4}$ No original: "Via ces tentatives d'historisation du cirque, il apparaît clairement que le cirque n'est pas né dans les formes que nous lui connaissons aujourd'hui ni dans celles d'hier. Comme tout art, il sets (dé)construit, enrichi de formes d'expression qui ont elles-mêmes évolué." (nossa tradução).
} 
Há de se acreditar que nas práticas circenses os movimentos e técnicas não são simplesmente aprendidos, mas são treinados e explorados repetidas vezes, até que isso entre dentro do corpo, de onde jamais sairá. Atrevo-me também a dizer que quando o circo entra na alma de um artista, ele se estabelece com tamanho encantamento que não é mais possível tirálo de lá.

Em 1999, no momento em que estava cursando o segundo ano do bacharelado em Dança na Universidade Estadual de Campinas, fui convidada por quatro colegas (Marília Ennes, da Companhia Paraladosanjos, Angélica Evrard, Carol Mandell e Tarina Quelho) para compor uma pequena turma de Tecido ${ }^{5}$ com a professora Monica Alla, que coincidentemente foi uma das fundadoras da Cia. Cênica Nau de Ícaros, num espaço chamado Irmãos Fratelli, em Cotia-SP. Mal sabia eu da importância desses dois núcleos artísticos para a história de uma geração de artistas e companhias que enraizaram as artes do circo na cidade de São Paulo-SP, e que veremos no relato mais detalhado sobre a Cia. Cênica Nau de Ícaros.

Assim como no circo, onde há um momento de suspensão da cena, no qual o atoracrobata está prestes a realizar algo surpreendente, ou quando, num salto mortal atinge o chamado "ponto zero" gravitacional, posso reconhecer que o momento em que o circo entrou, de forma definitiva e consciente, dentro de mim, foi quando eu subi no aparelho aéreo Tecido pela primeira vez. Numa fração de segundo algo aconteceu, e nada mais foi como antes. Digo que o circo entrou pelo ar, por uma fresta de medo misturado com êxtase e o encantamento se instalou, ficou, cresceu e continua crescendo.

Na identificação com uma memória corporal, as artes do circo têm como característica marcante a exposição do corpo de quem pratica, como diz Bolognesi (2003, p. 13), uma superação de limites biológicos e sociais numa relação espetacular de superação. Essa relação de risco iminente, esse lugar ligado à ação de voar, será identificado em muitas das características apresentadas neste histórico, que retratam as diversas formas com que esses corpos se relacionam com o espaço, em suspensão.

\footnotetext{
${ }^{5}$ Tecido, silk, tecido acrobático, são as várias formas de tratar uma técnica e um aparelho aéreo do circo.
} 


\subsection{A suspensão na história mundial do circo}

Há inúmeras referências e possibilidades de como a suspensão dos corpos e as acrobacias aéreas surgiram nos caminhos que desenharam na história das artes do circo. Observando diversas imagens e pesquisas, este relato é desenhado como uma possível história das acrobacias aéreas, e não tem o intuito de descrever cronologicamente todos os acontecimentos sobre a história do circo em geral. Propomos aqui transitar por essa história e destacar pontos relevantes, para esclarecer como a suspensão se tornou algo tão desejado e difundido nas artes cênicas.

Os primeiros registros das artes do circo em geral são de um período próximo ao século XXV a.C., na China. Imagens pintadas em vasos de cerâmica representavam demonstrações de habilidades físicas de equilibristas, contorcionistas e acrobatas que se apresentavam diante de uma plateia. $\mathrm{O}$ encantamento pelos corpos no ar e pelo impossível também aparece em relatos de que havia folguedos populares na China, cujo propósito de brincar era somado a uma preocupação estética e coreográfica, na qual indumentária, elementos musicais e cênicos remetem a um espetáculo circense com elementos aéreos.

No Egito foram encontradas por arqueólogos e historiadores nas margens do Nilo pinturas murais de malabaristas, paradistas ${ }^{6}$, homens com movimentos acrobáticos que trocavam os pés pelas mãos e imagens de escravos capturados que demonstravam habilidades em argolas e barras (ANDRADE, 2006, p. 21-22). Nesse contexto, imagens de corpos numa relação de suspensão podem ser observadas, bem como o movimento de inversão de apoios. O termo apoios invertidos é muito utilizado em práticas educacionais circenses, nas quais os pés ficam no ar e fora do chão, o corpo é colocado em equilíbrio numa posição contrária à cotidiana e a cabeça ou as mãos dão lugar aos pés.

A tradição de manipulação de objetos e acrobacias ligadas às artes do circo, relatadas a partir dos egípcios, foi transmitida a outros povos através das guerras e conquistas, houve uma difusão dos conhecimentos aos gregos, que a transmitiram aos romanos.

Há relatos de que nos Jogos Olímpicos, que começaram por volta do século VIII a.C na Grécia antiga, os atletas, em suas disputas, praticavam evoluções acrobáticas, com

\footnotetext{
${ }^{6}$ Paradista: artista que se equilibra com os apoios invertidos, o corpo se apoia nas mãos e pernas e pés ficam no ar.
} 
movimentos de corpos no ar, usando barras e argolas. Eles eram dispostos em espaços circulares, que permitiam maior visibilidade e interação, numa relação de igualdade e equidistância em relação ao centro do espaço, uma característica sociocultural e espacial comum às artes do circo.

Alice Viveiros de Castro, ao descrever os cavaleiros burlescos, os acrobatas que fazem rir e os clowns, resgata, nas origens do teatro de Aristófanes, artistas de circo representando um personagem falastrão, que mais tarde se torna o palhaço que, além de falar e contar histórias, realiza saltos acrobáticos, dança e canta (CASTRO, 2005, p. 47).

Nos anfiteatros e circos romanos podemos fazer uma associação entre as artes do circo e as exibições de cavalos, que poderiam ser as raízes das acrobacias equestres do século XVIII, as habilidades corporais dos gladiadores e, principalmente, dos condutores de cavalos, na representação das proezas nas guerras e reverência religiosa de divindades. No espaço físico do Circo Máximo em Roma, encontramos muitos símbolos e, como elemento arquitetônico central, havia um obelisco que, representando Augusto, evocava a ideia de suspensão, relacionada às divindades e ao Sol.

Figura 1 - Circo Maximus (50 a.C.)

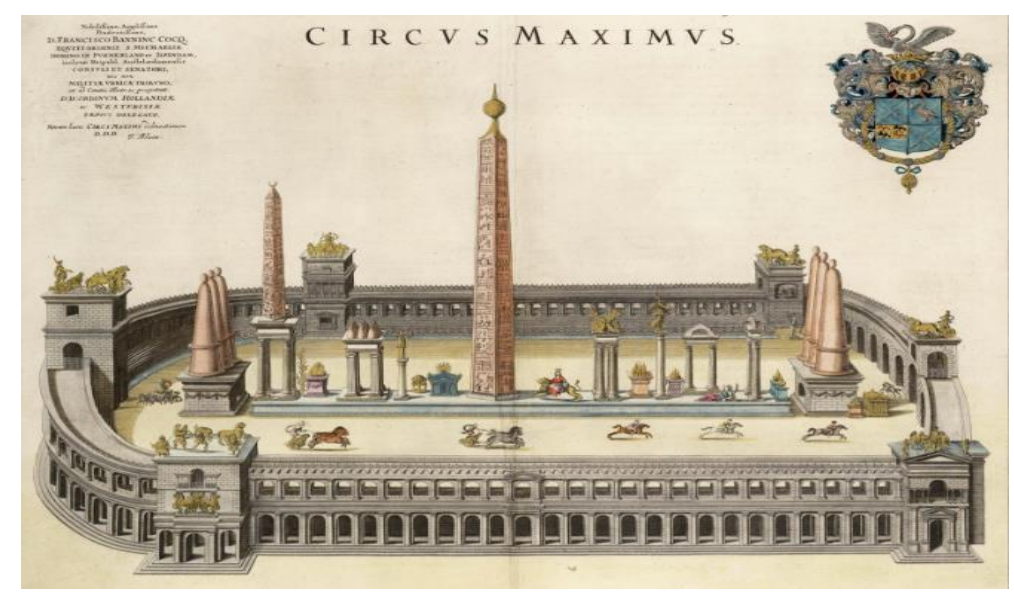

Fonte: Mundo de Babel. ${ }^{7}$

Os romanos propagaram os conhecimentos adquiridos através de trupes itinerantes. O nome saltimbancos, dado aos artistas nômades, itinerantes, que trabalhavam nas feiras,

\footnotetext{
7 Disponível em: <http://pedro-mundodebabel.blogspot.com.br/2012/03/maravillas-del-mundo-antiguo-viiiel.html.>. Acesso em: 02 out. 2016.
} 
também remete à suspensão dos corpos na busca das origens dos elementos aéreos do circo. A palavra, do italiano saltimbachi, ou saltar in banco, significa "pular sobre um banco" e relata o que muitos artistas de feira faziam em suas apresentações.

Podemos dizer que as origens das acrobacias aéreas estão relacionadas à necessidade do homem de dominar a natureza, pois a observação do voo dos animais pode ter sugerido que o homem precisava realizar gestos não habituais para ultrapassar os limites gravitacionais e genéticos.

A superação de limites, que fica evidente na suspensão do corpo, também é encontrada em outras práticas que originaram o circo: a presença de animais exóticos evidencia um confronto do corpo humano com o perigo, demonstrando um espaço específico de tensão sempre existente nas artes do circo.

Os animais exóticos, desde a Antiguidade, também fizeram parte das origens do circo; no contexto bélico, os cortejos após guerras traziam animais e seus domadores como exemplares das conquistas de novas terras. Os cortejos sempre foram as formas de chegada do circo e dos artistas nas cidades. Esse modo de habitar o espaço é uma forma comum de presença cênica e exploração do espaço pelos circenses, no qual havia demonstração de parte do espetáculo e atrações, e um nítido reconhecimento do espaço físico e social dos circos itinerantes, ou dos chamados artistas nômades.

Transgredir o natural, ultrapassar os limites e realizar o impossível são características básicas do espetáculo circense, na qual a proeza do corpo humano se torna base dessa arte (BOLOGNESI, 2003, p. 187). Destacando o corpo em suspensão e suas técnicas, cria-se um encantamento e uma aproximação estética através do extraordinário, com o intuito de tocar o público e explorar seus sentimentos e emoções.

Também há informações de que provavelmente o corpo suspenso que vemos nas artes do circo tenha surgido na China, a partir do aprimoramento das técnicas utilizadas para fuga de lugares de reclusão, como refúgios e prisões, que o estrito regime político da época impunha. A utilização de cordas e de outros elementos que permitiam subir e descer de alturas já delimitava possíveis acrobacias, que têm uma ligação muito forte com as práticas ligada à guerra, pois eram técnicas necessárias e frequentemente usadas pelos soldados nas práticas militares (BORTOLETO; CALÇA, 2007b).

O primeiro tratado de acrobacia, publicado em 1599 pelo italiano Angelo Tuccaro, intitulado Trois dialogues de l'exercice de sauter et voltiger en l'air, no seu título já indaga 
sobre a relação do corpo com o ar, as ações de saltar e voar. Possui diversas imagens de figuras acrobáticas que demonstram claramente as origens do circo, tanto no que se refere às posturas similares à ginástica, quanto nos conteúdos, em que o autor associa e identifica os corpos que estão em suspensão, com corpos e movimentos de dança e baile da época.

Figura 2 - Figura acrobática

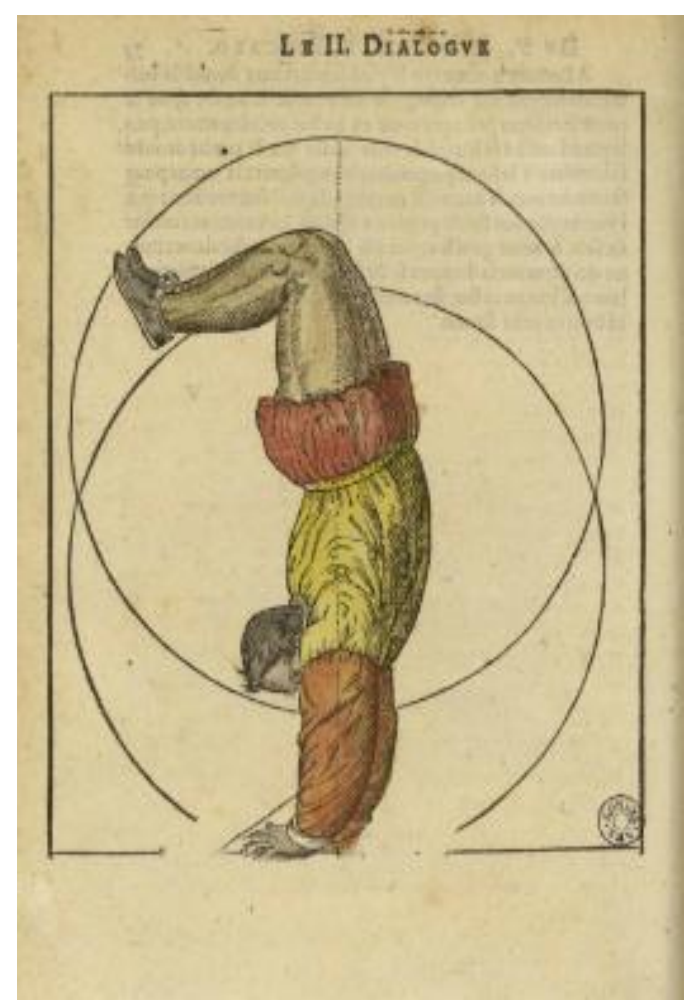

Fonte: TUCCARO, 1599, p. 168.

A identidade profissional dos nômades foi conquistada na Idade Média, nas feiras existentes em toda a Europa e a Ásia. Eram atores, adestradores de animais, funâmbulos em suas cordas suspensas, acrobatas e seus corpos volantes ${ }^{8}$, malabaristas que manipulavam todo o tipo de objeto, e equilibristas de números de icários. ${ }^{9}$

Alice Viveiros de Castro informa que os saltimbancos da Idade Média e do Renascimento tiveram papel fundamental na continuidade das artes do circo, principalmente

\footnotetext{
${ }^{8}$ Volante em francês significa voador.

${ }^{9} \mathrm{O}$ número de icários consiste em realizar equilíbrios em duplas, onde o volante é suspenso pelo portô deitado de costas e com as pernas para cima. Os pés do portô joga o volante para o alto e este realiza saltos no ar e volta novamente para os pés do portô.
} 
em números de comicidade física, que aliam a teatralidade cômica dos palhaços à agilidade dos acrobatas. O número de icários desenvolvido na Europa pela Trupe The Hallon-Lees, os mais famosos cômicos físicos do final do século XVIII, consistia em "um número arriscado, que exigia uma perfeita sincronia entre os acrobatas, e que só poderia ser realizado com um portô adulto e com crianças como volantes: icários. Deitados de costas, com as pernas para cima, o portô, que neste caso é chamado de icarista, joga para o alto e apara o volante, sempre usando os pés. A cada vez, o pequeno volante realiza saltos mais arriscados, rodando no ar até ser novamente amparado pelos pés do icarista” (CASTRO, 2005, p. 81).

Figura 3 - Performance de saltimbancos realizando número de icários

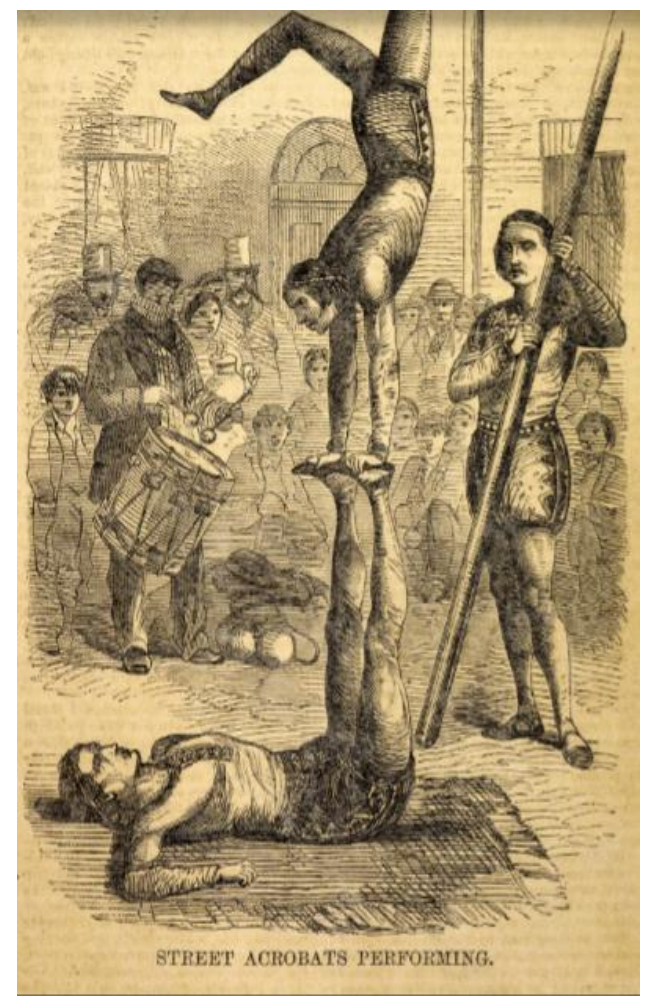

Fonte: MAYHEW, $1851 .^{10}$

As acrobacias de equilíbrio, com elementos e desenhos aéreos, e os acrobatas e jogadores de icários Hanson-Lee também são relatados por Mário Fernando Bolognesi, quando ele menciona a aproximação do circo com o teatro, através das pantomimas

\footnotetext{
${ }^{10}$ Disponível em: <http://www.bl.uk/victorian-britain/articles/popular-culture>. Acesso em: 20 set. 2016.
} 
desenvolvidas por esses cômicos físicos, num gênero chamado de arlequinadas, peças curtas descendentes da commedia del'arte, adaptadas para o espaço circense do circo moderno.

O fato dos nômades se estabelecerem como artistas nas feiras é parte da origem do chamado circo moderno, em suas características mais tradicionais, como o conhecemos atualmente, quando houve a união desses artistas aos espetáculos equestres, no século XVIII.

A gravura Le bon genre, datada de 1816, mostra uma performance ao ar livre em Paris. O acrobata saltimbanco, que está com sua cabeça sobre uma mesa, realizando um apoio invertido, é acompanhado por um homem sentado tocando violino e por um menino que dança com um gabarito. A possibilidade de serem artistas que se apresentavam em uma feira e a relação espetacular é celebrada com a presença dos espectadores, à esquerda uma mulher segurando uma menina pela mão, e uma outra mulher à direita. Os vestidos das mulheres são típicos das modas francesas e inglesas do começo do século XIX.

Figura 4 - Le bon genre (Paris, 1816)

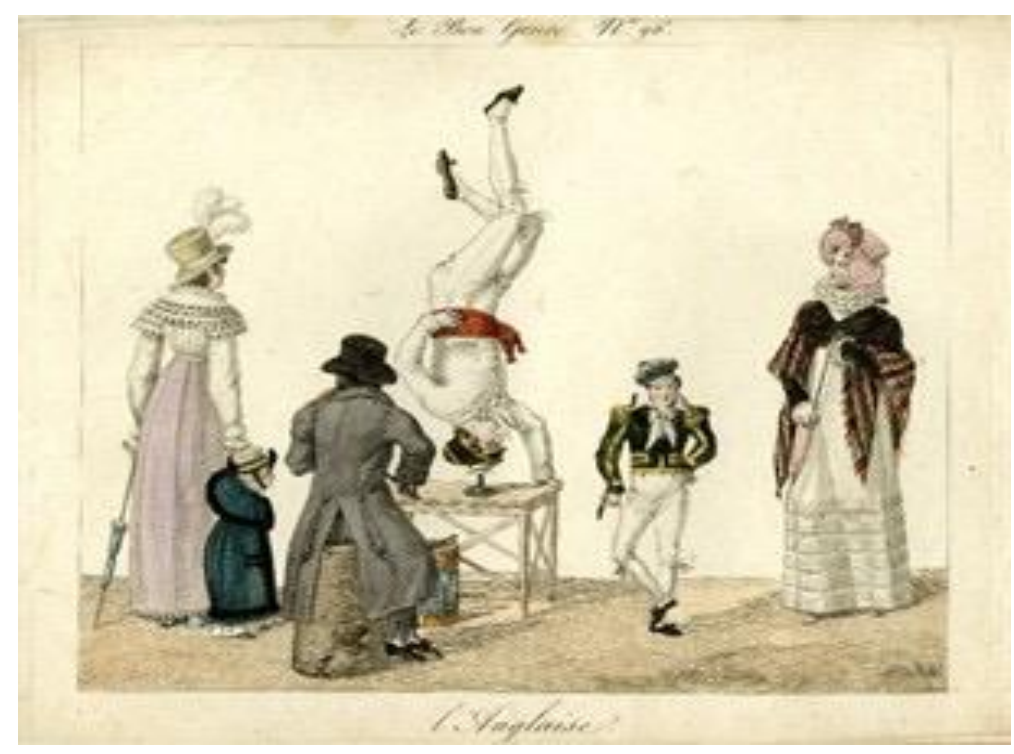

Fonte: History and other thoughts. ${ }^{11}$

\footnotetext{
11 History and other thoughts (jan. 2013). Disponível em: <http://historyandotherthoughts.blogspot.com.br/2013/01/le-bon-genre.html>. Acesso em: 04 out. 2016.
} 
As feiras se estabeleceram como espaço da cena e lugar de constantes trocas, e os artistas que mais se aproximavam dos acrobatas aéreos eram os dançarinos de cordas, os chamados funâmbulos ${ }^{12}$. Em muitos estudos encontramos como principal atração das feiras as acrobacias em corda esticada, que nos remete aos tradicionais números de arame ${ }^{13}$ ou corda bamba $^{14}$, ou mesmo, mais recentemente, a pessoas que se elevam em slacklines. ${ }^{15}$

Essas atrações são consideradas de equilíbrio, mas também aéreas, pois têm como característica marcante estar fora do chão, ultrapassar os limites gravitacionais habituais do homem. A brincadeira com a gravidade, constantemente explorada nas artes do circo, determina uma forma particular de estar no espaço, numa relação que ultrapassa o chão e se torna aérea.

As evoluções dos funâmbulos já eram conhecidas pelos gregos desde antes dos primeiros Jogos Olímpicos (VAN AELBROUCK, 1994, p. 48). Os primeiros dançarinos de corda se apresentavam utilizando uma corda esticada, girando em torno do seu eixo, e suspensos pelo pescoço ou pelos pés. Depois surgiram dançarinos que fluíam para cima e para baixo em uma corda, e também se apoiavam no ventre, com os braços e pernas estendidos. Também havia os que corriam grande perigo, deslizavam em uma longa corda esticada em linha reta e pulavam de uma corda a outra, para cima ou para baixo. E, por último, os funâmbulos que dançavam em cima da corda com muita naturalidade e segurando um contrapeso.

A descrição dos primeiros dançarinos de cordas na Grécia, que giravam em torno do eixo formado pela corda, anuncia a origem dos acrobatas suspensos, os chamados aerelistas, evocando uma forma específica de suspensão encontrada nos futuros números de trapézio fixo e aparelhos aéreos como a corda marinha ${ }^{16}$ e o tecido marinho ${ }^{17}$. A gravura La célèbre

${ }^{12}$ Funâmbulo: equilibrista que faz apresentações públicas andando no arame ou na corda bamba; anemóbata, burlantim. Disponível em: 〈http://michaelis.uol.com.br/busca?id=ANBl〉. Acesso em: 01 out. 2016.

${ }^{13}$ Arame: número circense em que o acrobata se equilibra e anda sobre um arame esticado.

${ }^{14}$ Corda bamba: número circense que consiste em equilíbrio sobre uma corda elevada, no qual o movimento de balanço se dá pelo fato da corda estar "frouxa".

${ }^{15}$ Slackline: prática esportiva que consiste em caminhar, equilibrando-se sobre uma fita ou corda de náilon, bem esticada e presa entre duas árvores, duas pilastras etc., geralmente a uma altura de $30 \mathrm{~cm}$ do solo. Disponível em: <http://michaelis.uol.com.br/busca?id=RQ8Wa〉. Acesso em: 01 out. 2016.

${ }^{16}$ Corda marinha: é uma corda presa pelas duas extremidades na mesma altura, numa distância de 3 a 5 metros. A distância entre os pontos de fixação é tradicionalmente igual à metade do comprimento da corda, na qual o acrobata realiza evoluções em balanço ou estáticas parecidas com as desenvolvidas no trapézio em balanço, quando utiliza o meio da corda.

${ }^{17}$ Tecido marinho: modalidade de tecido que difere das outras na sua amarração, sendo preso pelas duas extremidades numa distância de 2 a 3 metros, formando o desenho de uma balança. Os movimentos são realizados no meio do tecido, de maneira parecida com outra modalidade circense, a corda marinha. 
hollandaise, publicada em um estudo sobre os habitantes de Londres no final do século XVII, do livro The cryes of the city of London drawne after the life (1687-89) demonstra que na origem das acrobacias aéreas estão os dançarinos de corda (NOEL, 2008, p. 84).

Figura 5 - La célèbre hollandaise (ilustração de Mauron Delin)

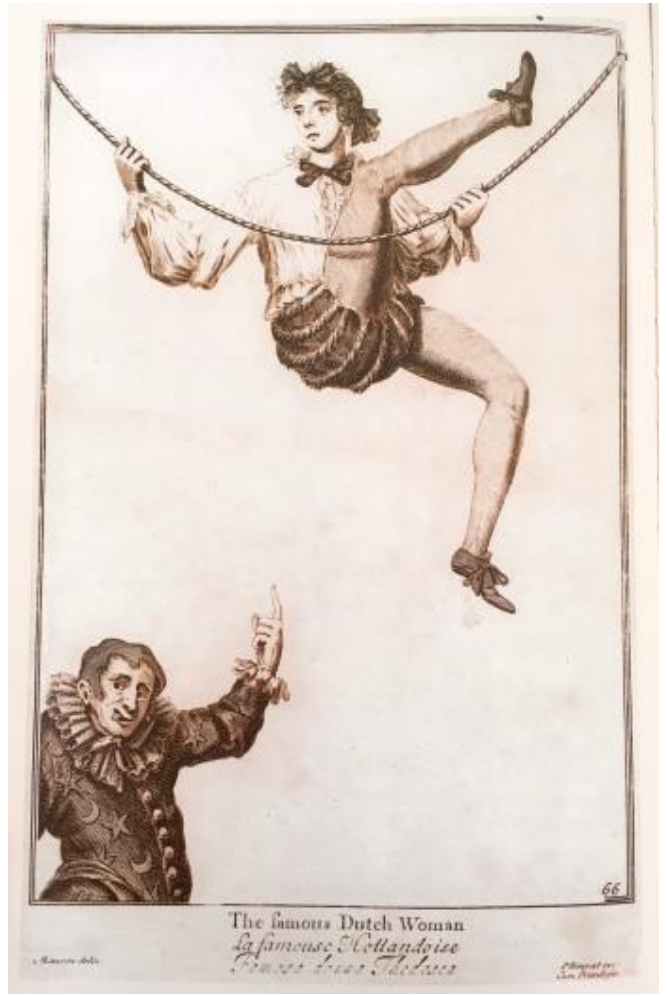

Fonte: NOEL, 2008, p. 84.

$\mathrm{Na}$ segunda metade do século XVIII, acredita-se que foram as artes equestres e o espaço da cena em que estavam inseridas que deram origem ao circo moderno, também chamado de circo tradicional.

Nesse momento da grande mudança das artes do circo, de criação do chamado circo moderno, as acrobacias realizadas nos cavalos são uma forma de estar acima do chão. A força centrípeta dos corpos, aliada ao movimento rápido e circular das acrobacias equestres, possibilitou ao artista-acrobata e militar, além de destacar o cavalo como grande símbolo da aristocracia, relatar de maneira surpreendente as façanhas das guerras, através de seus corpos suspensos.

Os chamados voltigeurs à le cheval anglais, acrobatas a cavalo ingleses, eram muito comuns e populares nessa época. Eram cavaleiros das forças armadas que se apresentavam em praças públicas, com os pés fora do chão, sobre o dorso de um ou mais cavalos. 
A palavra francesa para acrobata, voltigeur, vem do verbo voltiger, que possui diversos significados, como: voar aqui e lá, com frequentes repetições; ser levado flutuando no ar; se movimentar, dançar com velocidade e leveza; passar, saltar rapidamente de um objeto a outro ${ }^{18}$. A busca pelas definições da palavra acrobata em francês, mais do que investigar a origem dos acrobatas a cavalo, nos aproxima de tal forma das origens do circo que, por um instante, parece que estamos descrevendo um número aéreo de um espetáculo circense. A palavra volteio define a arte de acrobacias com cavalos.

Acrobacias e movimento já desenham um espaço da cena dinâmico e suspenso. Como suporte natural para os voltigeurs, o cavalo suportava todo o tipo de variação acrobática, desde as variações estáticas, como também a composição espacial de dois ou três cavalos como base para uma pirâmide complexa. Os Les Caroli ${ }^{19}$, no século XVII, foram acrobatas muito conhecidos pelas performances, que se assemelhavam a andaimes humanos, elaborados sobre cavalos em movimento (JACOB, 2001, p. 36).

Figura 6 - Família Les Caroli. Número equestre de piramide humaine

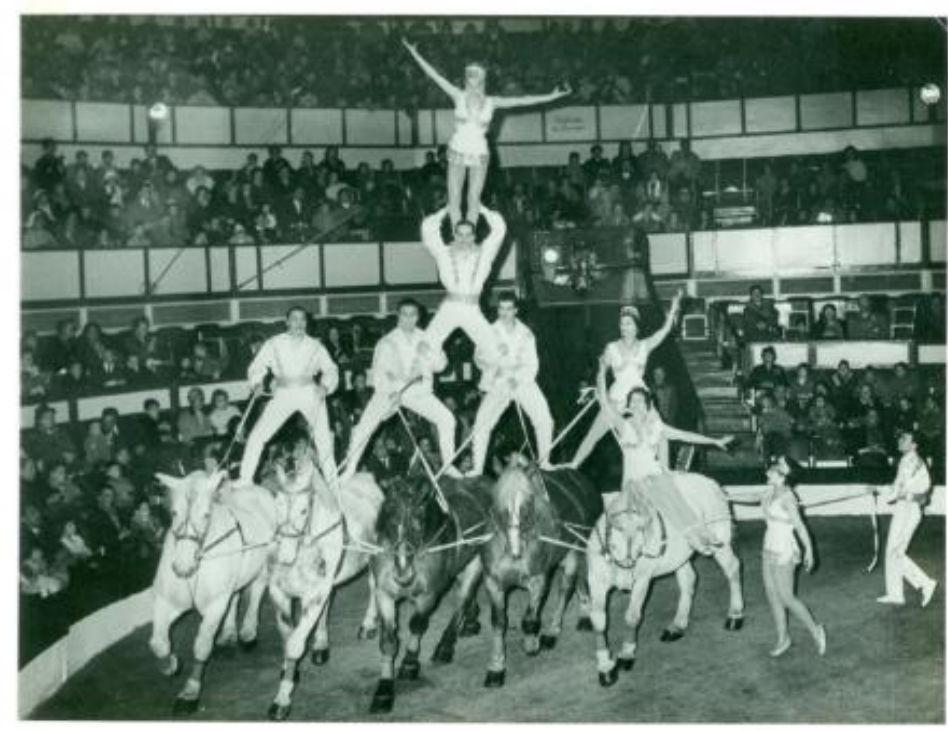

Fonte: Foto do Circo Pinder $(1967)^{20}$

\footnotetext{
${ }_{18}^{18}$ Disponível em: <http://www.larousse.fr/dictionnaires/francais/voltiger/82493>. Acesso em: 02 out. 2016.

19 "C'est une troupe de clowns Italiens de trois frères Caroli, Enrico et Ernesto Francesco.Ils exécutent avec maîtrise; voltige,sauts périlleux, élévations et pyramide. Ils se présentèrent dans plusieurs cirques à travers l'Europe. Ils furent nommer les 7 merveilles du cirque et en deuxième partie les trois frères réapparaissaient grimer clowns." (Disponível em: <https://www.delcampe.net/en_GB/collectables/photography/photographs/other/photo-cirque-pinder-pisteaux-etoiles-les-8-caroli-attraction-equestre-la-pyramide-humaine-1967-374045984.html>. Acesso em: 10 out. 2016).

${ }^{20}$ Disponível em: <www.delcampe.net>. Acesso em: 10 out. 2016
} 
A criação do circo moderno é atribuída ao sargento major da cavalaria inglesa Phillip Astley (1742-1814), que em 1768 foi responsável por apresentar uma diferente composição do espaço físico e arquitetônico destinado às artes equestres. As exibições acrobáticas sobre cavalos, que antes aconteciam ao ar livre, foram por ele levadas para dentro de um recinto fechado. Construiu uma arena sem cobertura de 13 metros de circunferência, com tribunas de madeira em frente a uma pista circular, que possibilitava, devido à força centrípeta, uma maior velocidade e desenvoltura dos exercícios a cavalo, ou seja, o formato circular ajudava os acrobatas a praticar suas acrobacias mais facilmente, e enquanto o cavalo corria em círculos, a figura central do cavalo começou a perder importância para o homem, com suas suspensões, saltos e giros.

Esse espaço da cena de formato circular criou uma arena onde diversos artistas e cenas despertavam a atenção de um grande número de pessoas. A primeira sessão do espetáculo organizado por Ashley, com a cobrança de ingressos, teve tamanho sucesso que permitiu que ele alugasse o terreno onde construiria, em poucos anos o Anfiteatro Astley, no qual também havia uma escola de equitação. Também possibilitou a um público de diversas classes frequentar um espaço de acontecimentos artísticos.

Figura 7 - Cartaz de divulgação do Astley’s Royal Amphitheatre (1850)

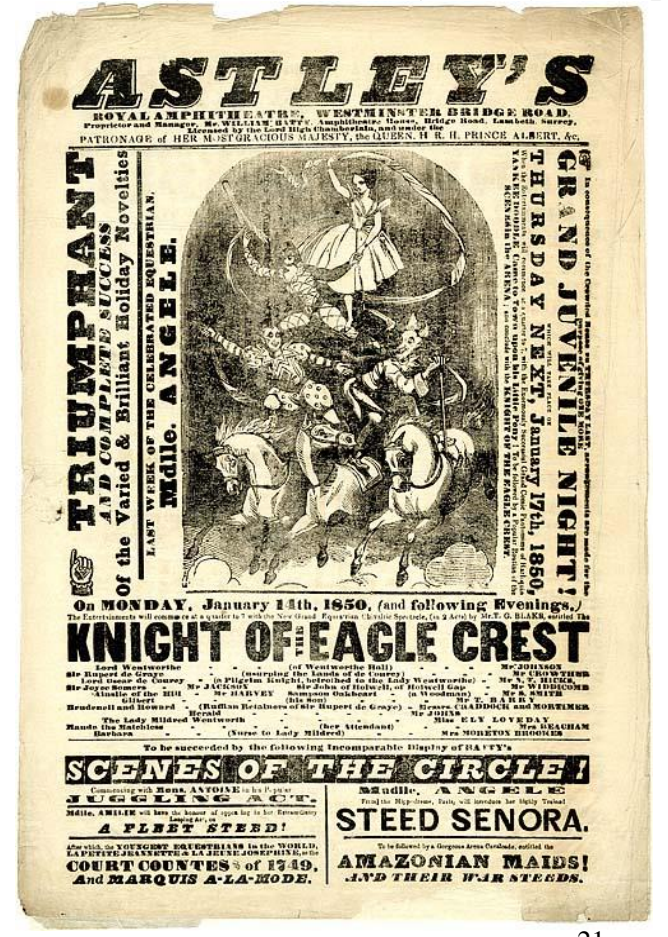

Fonte: Toronto Public Library. ${ }^{21}$

\footnotetext{
${ }^{21}$ Disponível em: <http://static.torontopubliclibrary.ca/ve/circus/history_astley.html>. Acesso em: 10 out. 2016.
} 
A princípio havia apenas apresentações com cavalos, mas depois as acrobacias e saltos eram apresentados junto a pantomimas equestres, também chamadas de hipodramas (CASTRO, 2005, p. 57) que, inspiradas nos teatros comerciais da época, descreviam cenas e conquistas militares. Posteriormente, essas cenas foram se ampliando para farsas sobre heróis tradicionais do teatro elisabetano. Para popularizar os espetáculos equestres, Astley decidiu mesclar, entre um número e outro de cavalos, acrobatas, malabaristas e funâmbulos vindos das feiras e teatros londrinos.

Foram as artes espontâneas desenvolvidas nas ruas e praças de Londres nessa época que trouxeram, além dos artistas, montadores vindos do exército para a criação e manutenção desses espetáculos. Acredita-se que o desenvolvimento de novas técnicas foi crescendo no decurso de uma plateia ávida por novidades e destrezas maiores, e por esse motivo a arte equestre foi ganhando tanta importância quanto as outras modalidades.

O nome "circo" foi utilizado pela primeira vez em 1780 por um artista da primeira formação da trupe de Astley, Charles Hughes, que junto com o compositor Charles Dindin, montaram sua própria companhia e construíram um luxuoso anfiteatro, com o nome de Royal Circus Equestrian and Philarmonic Academy. Mais conhecido como Hughe's Royal Circus, o espaço se assemelhava ao primeiro Anfiteatro Ashley, mas atrás da pista equestre foi adicionado um palco, como nos teatros, que se tornou modelo para todos os circos europeus e americanos, até o final do século XIX. Esse espaço alterou o espetáculo equestre, que passou a ter ainda mais presentes elementos de teatro e mímica.

Astley inaugurou em 1783 um anfiteatro em Paris, onde construiu a mesma estrutura de espaço da cena, com pista e palco. Quando foi proibido de permanecer na França, a estrutura foi recuperada pelo italiano, radicado na França, Antonio Franconi (1738-1836), que estabeleceu sua própria companhia no mesmo local, em 1793, como Amphithéâtre Franconi e, em 1807, após algumas mudanças, o Cirque Olympique. Franconi foi considerado um grande diretor e empresário de circo, responsável pela difusão do circo por toda a Europa e a América.

É importante destacar que a exibição de força física humana ganhava grande importância nos anfiteatros fixos, cujas estruturas de madeira, com sua grande imponência, permitiam ampliar as possibilidades de suspensão. Os espetáculos circenses que evidenciavam o potencial humano, inaugurado pela acrobacia equestre, possibilitou que 
outras modalidades ganhassem importância, como os saltos, os equilíbrios, a dança, o malabarismo. Os corpos dos artistas em suspensão se transformaram em alvo preferencial das atenções, pois esforço físico, o risco, a perfeição no desenrolar das cenas, a dedicação, o treino e a disciplina faziam desse universo impossível algo mágico e encantador.

A ascensão dos circos e seus espetáculos múltiplos durante o final do século XVIII e início do XIX causaram conflitos com os produtores teatrais. A Comédie Française proibia o uso do diálogo por todos os concorrentes do teatro. Os teatros de feira e os saltimbancos sobreviveram pelo desenvolvimento de números com o uso do corpo, da mímica e das acrobacias. Na Inglaterra, o teatro preferiu incorporar ao invés de combater esses artistas que faziam com que o espetáculo criado por Astley tivesse tanto sucesso.

$\mathrm{Na}$ Europa como um todo, a proibição dos cômicos dos circos de usarem a linguagem verbal dentro do picadeiro impulsionou o desenvolvimento das acrobacias em geral. Somente a partir de 1865 é que na França foi flexibilizada a proibição dos palhaços estabelecerem diálogos e representações mais ligadas ao teatro da época. O desenvolvimento da mímica e as intervenções puramente visuais fizeram com que os cômicos, que eram eximes acrobatas, também desenvolvessem números e cenas ligados às acrobacias aéreas. Para um cômico realizar um número aéreo, para ele conseguisse "brincar" com as grandes dificuldades que as técnicas aéreas impõem, ele precisava aprender essa técnica e treinar.

Os números aéreos cômicos surgiram a partir de grandes acrobatas que se incomodavam com a seriedade da disciplina militar, ou aquele que não tinham mais o vigor da juventude, mas que possuíam toda a bagagem e técnica de muitos anos de experiência, que possibilitava transcender e tornar cômico um número aéreo de grande dificuldade.

O domínio do ar sempre foi algo ideal e imaginado, que sempre se praticou desde a Grécia. Aparelhos para a suspensão de corpos, adaptados das feiras da Europa, foram usados dentro de produções de ballets no século XIX, assim como as posições dos dançarinos de corda, que tinham correspondência com posições da técnica de ballet. Os atos corporais ligados à ação de voar demonstram um corpo com habilidades que domina um espaço aéreo, que além de um espaço geográfico, é um espaço cultural. 
O circo apareceu também como um lugar de grandes possibilidades, do impossível, o lugar das invenções, onde era possível transcender exercícios e movimentos simples, criar algo fabuloso aos olhos do espectador, voar diante da plateia.

As adaptações das cordas utilizadas pelos funâmbulos se desenvolveram naturalmente dentro dos espetáculos equestres e dos circos. O trapézio surgiu de uma necessidade de ampliar a dificuldade dos movimentos acrobáticos, aliado ao desenvolvimento espacial das cordas, ou seja, criar novas formas de estar e voar naqueles aparelhos. Os acrobatas e dançarinos de corda primeiramente começaram a balançar em uma corda individual, depois ampliaram a quantidade de cordas e balançavam em duas, alternando saltos de uma a outra. $\mathrm{O}$ trapézio nasceu quando uma barra de ferro foi acrescentada e apoiada entre as cordas.

O trapézio foi inventado pelo coronel Amoros, por volta de 1813; inspirado em acrobatas italianos, na sua origem tinha um formato triangular, pois as duas cordas que suportavam a barra tinham apenas um ponto de ancoragem. Em 1850, no exterior do hipódromo de Paris, um trapézio foi ancorado em um balão e o voo cativo ${ }^{22}$ fazia parte da demonstração. Na mesma época, Henri Maitrejean, discípulo de Amoros, desenvolveu no circo acrobacias com corda lisa, argolas e trapézio fixo (BOUDREAULT, 2002, p. 76).

Em 1859, o ginasta Jules Léotard inventou o trapézio de voos, ou trapézio volante. Ele desenvolveu suas habilidades aéreas num momento histórico francês de expansão das produções de performances ligadas aos ballets franceses, notoriedade dos dançarinos de corda e crescimento do teatro sem palavras (a mímica). Culturalmente, os olhares para o ar também cresciam, devido aos experimentos da aviação francesa, que progrediam para a invenção do que podemos chamar de voo mecânico, durante os anos de 1850 e 1860. Assim, podemos dizer que o voo humano foi possível graças ao desenvolvimento das artes do circo, em especial das acrobacias aéreas.

\footnotetext{
${ }^{22}$ Voo cativo: quando o balão de ar sobe verticalmente a, no máximo, 20 metros de altura, preso por cordas.
} 
Figura 8 - Jules Léotard (1850)

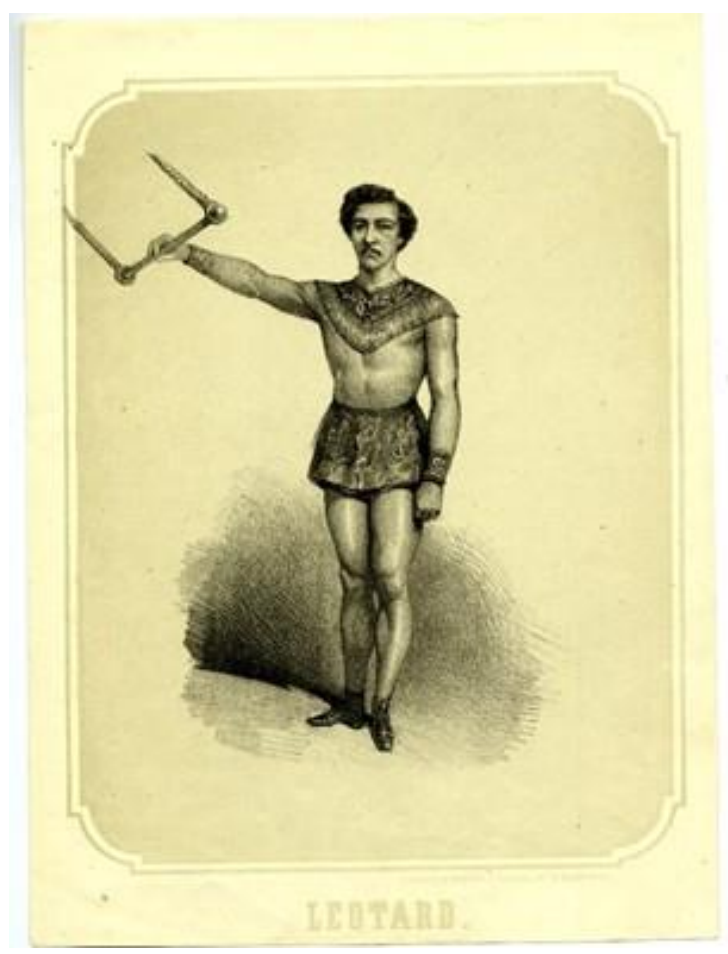

Fonte: British Museum. ${ }^{23}$

Jules Léotard (1838-1870) foi o acrobata francês que idealizou e realizou a primeira performance em um trapézio de voos, junto com Franconi, no Cirque Napoléon (lugar que hoje existe o Cirque d'Hiver), em Paris, em 12 de novembro 1859 (TAIT, 2005, p. 11). Há registros de que ele voava com muita facilidade e tinha como particularidade um sincronismo absoluto com a música. Mais tarde seu nome foi associado a um tipo de vestimenta comum a quem realizada acrobacias, uma malha colada ao corpo, sem mangas que ele normalmente usava, e que tinha a particularidade de deixar à mostra sua forte estrutura muscular, decorrente da prática do trapézio.

Em 1861, multidões se reuniam para ver Léotard, que fez sua estréia em Londres no Teatro Alhambra (Music Hall), onde as pessoas jantavam enquanto ele voava pelo ar acima de suas cabeças. Até mesmo uma canção sobre ele foi escrita na década de 1860, com arranjos de Gaston Lyle e letra do cantor George Leybourne, conhecida como "Champagne Charlie".

\footnotetext{
${ }^{23}$ Portrait of Jules Léotard, standing and looking to front, his right arm reaching up to grasp a trapeze; he wears fringed trunks with a matching collar and wrist band. 1850s. (Disponível em: $<$ http://www.britishmuseum.org/research/collection_online/collection_object_details.aspx?objectId=3232038 \&partId=1>. Acesso em: 10 out. 2016).
} 
Léotard e o famoso funâmbulo francês Jean François Gravelet, "Blondin" (18241897), foram os responsáveis pelo desenvolvimento das performances no trapézio, comuns em circos do século XIX. Léotard, desde a adolescência desenvolvia e praticava os truques no trapézio, que era instalado em cima de uma piscina, que servia como rede de segurança.

A ação realizada no trapézio foi logo comparada à dança, e chamado de "ballet aéreo". Consiste em um acrobata, chamado de volante, sair em balanço de uma plataforma alta, segurando na barra do trapézio, de onde solta a mão em direção a outro acrobata, o chamado portô, que, pendurado em balanço, agarra a mão do volante. Eles continuam balançando, até que o portô lança o volante de volta para a barra do primeiro trapézio em balanço. Nesse caminho, o volante realiza giros e voltas, que foram desenvolvidas pelos artistas de circo e alcançaram graus de dificuldade inimagináveis (CAVENDISH).

No século XIX, a expansão do circo pelo mundo foi em grande parte consequência da formação das famílias circenses, estabelecidas pela união dos saltimbancos com os acrobatas militares. A expansão para Rússia aconteceu em 1793, quando Charles Hughes (Hughes Royal's Circus) apresentou um número exclusivo para Catarina, a Grande, em São Petersburgo. No mesmo ano, o acrobata equestre britânico John Bill Ricketts abriu o primeiro circo nos Estados Unidos, na Filadélfia. Em 1797, Ricketts também estabeleceu, em Montreal, o primeiro circo canadense. No México, o circo apareceu pela primeira vez em 1802, levado pelo acrobata equestre britânico Philip Lailson (JANDO).

O declínio dos cavalos como atração principal dos circos deveu-se em parte ao desenvolvimento das acrobacias aéreas, mas também à invenção dos trens e automóveis, que substituíram os cavalos. Na maioria dos circos europeus, os números equestres deram lugar ao treinamento de animais exóticos, números de acrobacia aéreas e terrestres, malabaristas e palhaços. Também o interesse pela ginástica e atividades físicas, com o ressurgimento dos Jogos Olímpicos, em 1896, impulsionou o desenvolvimento ainda maior dos números acrobáticos no circo, no lugar dos equestres.

O treinamento de animais exóticos, como característica já citada de superação de limites humanos no confronto do corpo humano com o perigo (um espaço específico de tensão), teve sua aparição marcante no circo moderno por volta de 1812, quando os Franconi apresentaram o primeiro elefante treinado, chamado Kioumi, no Circo Olímpico de Paris (JANDO). Destacamos nas apresentações de animais selvagens, que também tiveram grande expansão na Europa, África e América, as acrobacias realizadas no dorso de elefantes.

Os corpos em suspensão nos elefantes aparentemente remetem às acrobacias equestres, mas se apresentam como elementos aéreos em equilíbrio que possuem mais 
delicadeza por não estarem em grande velocidade centrípeta. A relação espacial que o tamanho dos elefantes estabelece, entre o pequeno e o grande, o selvagem e o humano, possui uma beleza particular presente nesse tipo de suspensão.

$\mathrm{Na}$ evolução das artes do circo nos Estados Unidos, o desenvolvimento tecnológico e a expansão espacial do circo estão intimamente ligados às suspensões. A criação de uma identidade e de dinâmicas próprias foi consequência de um número cada vez maior de espectadores, em decorrência do surgimento de circos que ampliaram seus espaços para dois ou três picadeiros sob a mesma lona, com ações acontecendo ao mesmo tempo. Essa multiplicidade de signos, o vislumbre de técnicas, coragem e superação física fizeram com que o circo se transformasse em um ícone americano. Os empresários William Cameron Coup (1837-1895) e Phineas Taylor Barnum (1810-1891), em 1872, eram donos da maior empresa de circo americana, seguidos por Bailey, em 1881, e pelos Ringling Brothers, em 1887. A expressão criada por Barnum, "o maior espetáculo da terra", refletia o que as artes do circo representavam para os americanos no final do século XIX e início do XX. A junção das empresas William Cameron Coup \& Phineas Taylor Barnum, Bailey e Ringling Brothers se efetivou em 1906, quando surgiu o Ringling Bros. and Barnum \& Bailey (JANDO).

Pascal Jacob (2001, p. 33) cita que havia, na formação espacial do circo americano, sob a mesma lona, com três picadeiros de 13 metros de circunferência cada um, uma justaposição de números com temas em comum, que mobilizavam todos os artistas ao mesmo tempo, remetiam aos teatros romanos e davam a impressão de uma feira organizada. Evidenciada na evolução histórica das artes do circo, essa característica própria circense de recuperação das origens e a necessidade de superar e aperfeiçoar os modos de estar em cena, cria desenhos no espaço, comuns e ao mesmo tempo inovadores, que podemos identificar na suspensão dos corpos e na suspensão da cena.

Na segunda metade do século XIX, aparecem nos muros os primeiros cartazes de divulgação dos circos, com muitas ilustrações coloridas e uma enorme riqueza de detalhes. Pascal Jacob relata que três semanas antes do circo chegar, milhares de cartazes já eram espalhados nas cidades de destino, e que, em 1910, o Circo Ringling colou cerca de dez mil cartazes por dia, resultando em uma imprensa especializada na criação e edição dos chamados Afiches de cirque (JACOB, 2001, p. 76).

Observando alguns cartazes, obtemos muitas referências visuais que exemplificam a suspensão, bem como a aparição e as origens de diversos aparelhos, números aéreos e técnicas desenvolvidas. 
No cartaz Descente d'Absalon par Miss Stena ${ }^{24}$, podemos observar diversas formas de suspensão, através de trapézios, portagens com força capilar e suspensões em balões de ar quente, muito comuns na época.

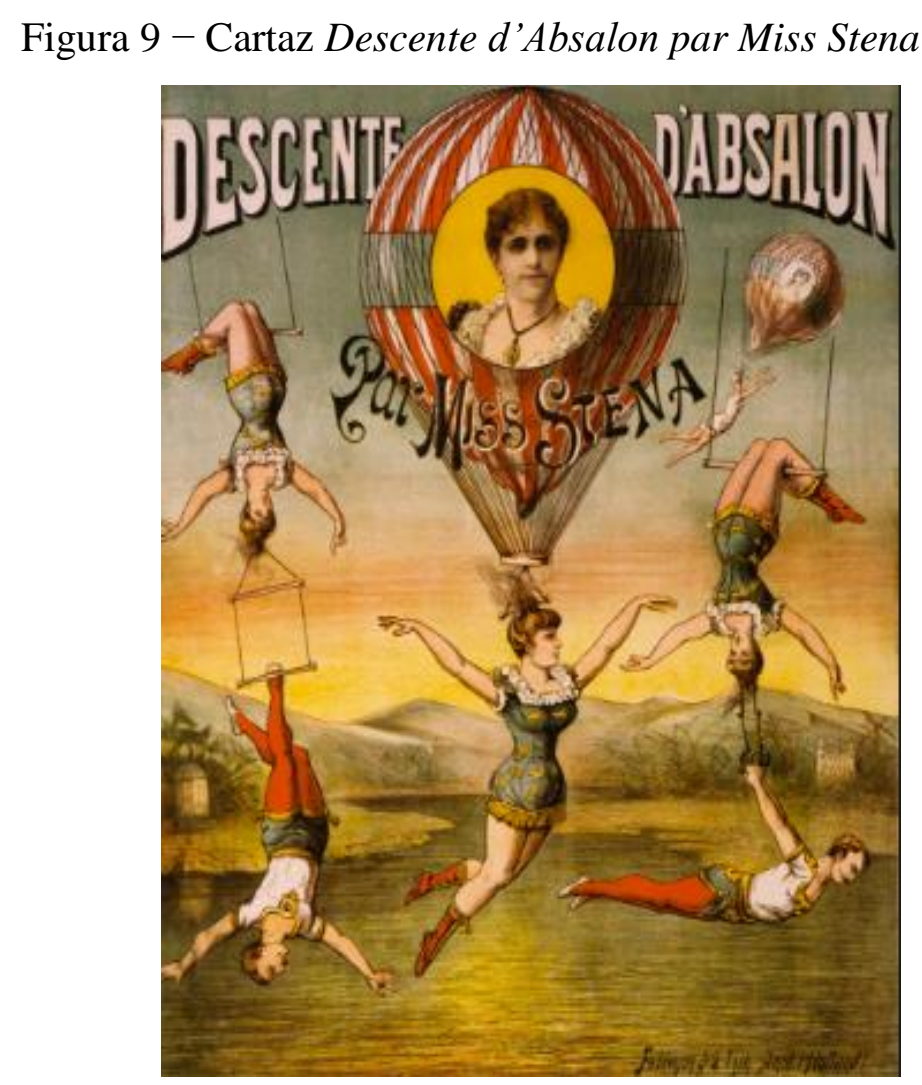

Fonte: Vintage Everyday.

Uns dos mais famosos cartazes de circo é o Female trapeze acrobats at circus ${ }^{25}$, no qual os movimentos de suspensão estão dispostos em vários planos diferentes, a técnica do trapézio volante (ou de voos) retratada no momento exato em que o volante está no ponto chamado "zero" antes de agarrar a mão do portô, a corda lisa enrolada no corpo que permite o acrobata estar de ponta-cabeça e a força bocal, que é um dos números mais tradicionais de suspensão no circo; no fundo, abaixo, observa-se o exato momento de suspensão em um número de acrobacia equestre.

\footnotetext{
${ }^{24}$ Disponível em: <http://www.vintag.es/2016/05/vintage-attractive-posters-of-circus.html>. Acesso em: 12 out. 2016

${ }^{25}$ Disponível em: <https://www.loc.gov/item/93500071/>. Acesso em: 12 out. 2016.
} 
Figura 10 - Cartaz Female trapeze acrobats at circus (1890)

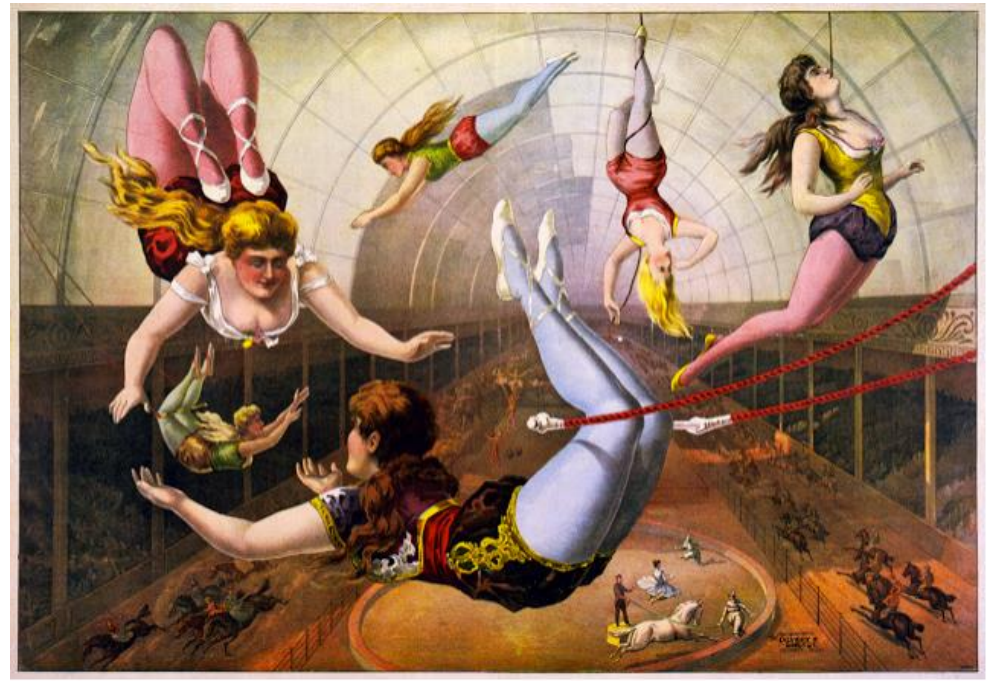

Fonte: Library of Congress.

O cartaz Downie Bros Aerialists, de $1931^{26}$, também demonstra diversas técnicas e aparelhos aéreos do circo na primeira metade no século XX; além de trapézios e cordas, existe a representação de um número com argolas na parte superior direita. A herança que as acrobacias aéreas têm da ginástica fica evidente quando um número como esse é retratado.

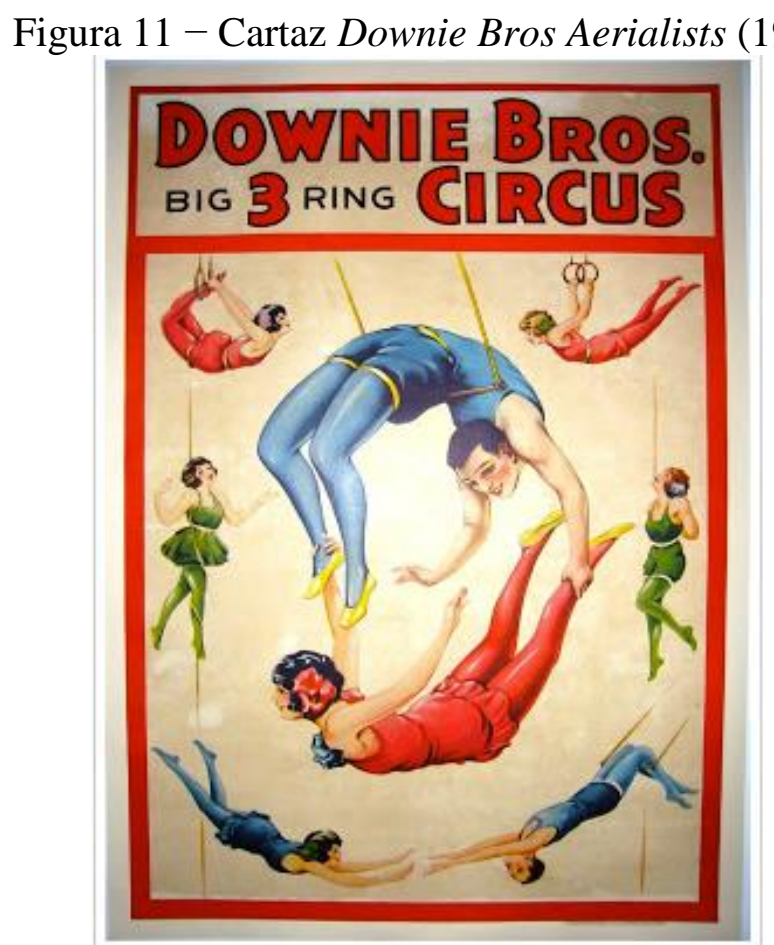

Fonte: Circus Posters.

${ }^{26}$ Circus Posters, ago. 2008. Disponível em: <http://circusposters.blogspot.com.br/2008/08/downie-brosaerialists-c1931.html>. Acesso em: 12 out. 2016. 
Ao mesmo tempo, pintores e poetas, fascinados pelos acrobatas aéreos, continuaram a descrevê-los e representá-los. Em seu livro "Portrait de l'artiste en saltimbanque", Jean Starobinski destaca a dualidade fascinante do um acrobata aéreo, entre a vida e a morte, como uma preocupação comum dos artistas do século XX. Guillaume Apollinaire, em um texto poético sobre o quadro Les saltimbanques (1905), de Pablo Picasso, fala de uma "agilidade difícil”, referente aos acrobatas aéreos (DUMONT, 2015, p. 22).

Durante muito tempo, os exercícios aéreos eram considerados muito acrobáticos pelos ginastas e muito ginásticos pelos artistas do circo, que transformaram as demonstrações ginásticas em atração. É o caso da corda lisa, que era utilizada pelos ginastas para preparação corporal e foi primeiramente utilizada para subir em estruturas circenses, ou mesmo em um aparelho circense. Lilian Leitzel (1892-1931) ${ }^{27}$ é um exemplo do começo do século XX; ela utilizava uma corda lisa para subir no trapézio e, nesse movimento de suspensão, executava uma série de movimentos acrobáticos chamados pranchas.

Figura 12 - Cartaz de Lilian Leitzel (1929)

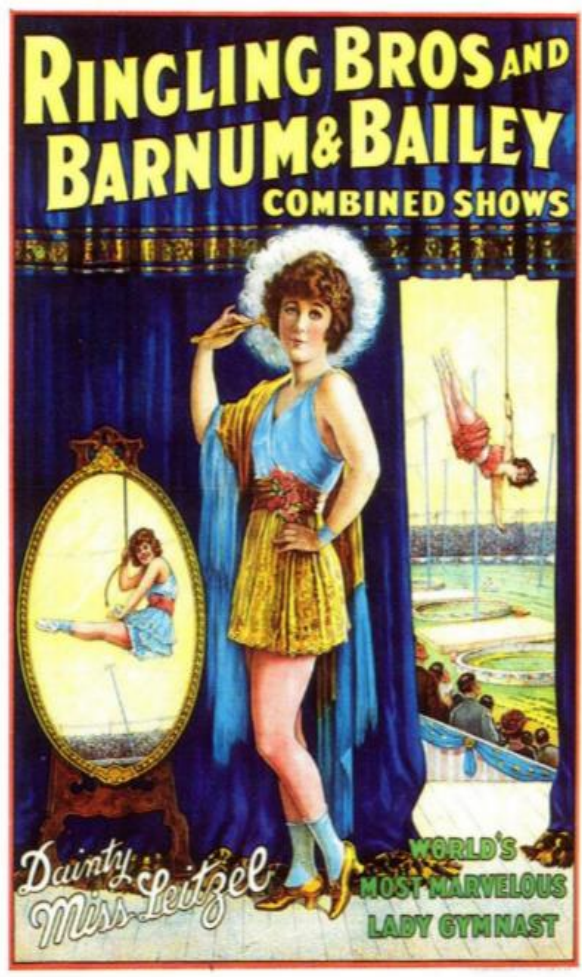

Fonte: Circuses and side shows.

\footnotetext{
${ }^{27}$ Disponível em: <http://www.circusesandsideshows.com/performers/lillianleitzel.html>. Acesso em: 12 out. 2016.
} 
As técnicas acrobáticas aéreas também tiveram um grande aperfeiçoamento, quando se passou a utilizar uma corda de segurança, chamada de lonja, que permitia aos acrobatas treinar e desenvolver movimentos inéditos (BOUDREAULT, 2002, p. 77).

Após a Primeira Guerra Mundial, a ênfase nas habilidades corporais e as suspensões em grandes alturas ocuparam definitivamente o lugar das figuras e números equestres. A evolução dos movimentos e a ação cada vez mais ligada a uma arte do "impossível” pode ser observada no triplo mortal de Alfredo Codona no trapézio de voos ou por figuras como Con Colleano dançando no arame.

Figura13 - Cartaz Os Codonas de J. Pöhm (1925)

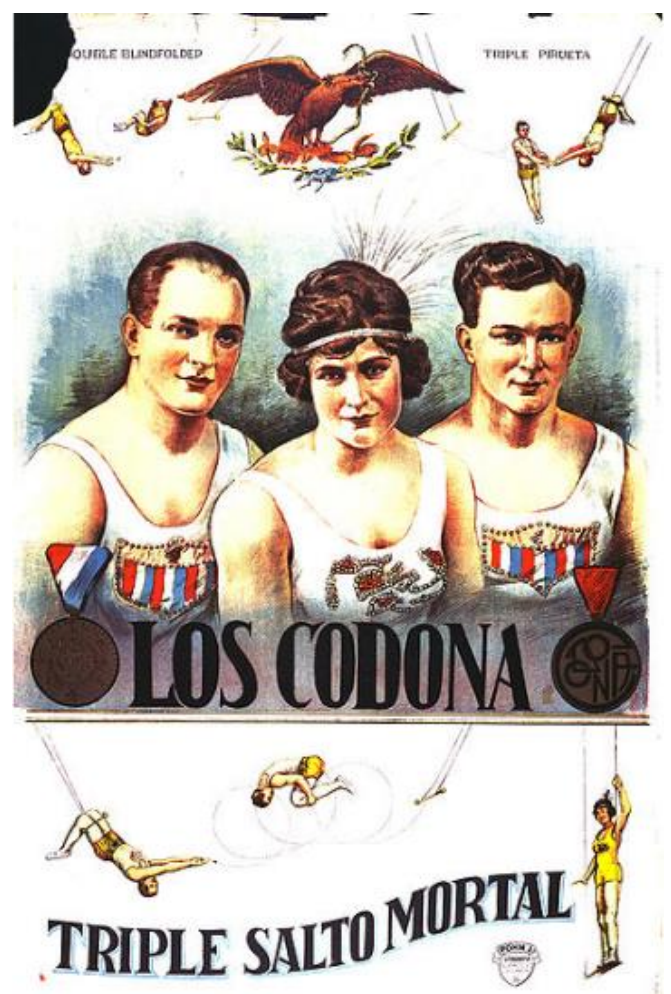

Fonte: Circopedia. ${ }^{28}$

Entre 1945 e 1970, houve na França uma estagnação no meio circense mas, após esse período, o surgimento das escolas de circo impulsionou uma grande produção e evolução técnica, e os artistas lá formados passaram a se reinventar anualmente, criando coletivos e companhias.

\footnotetext{
${ }^{28}$ Disponível em: <http://www.circopedia.org/File:Los_Codona_poster.jpg>. Acesso em: 10 out. 2016.
} 
Em 1927, na Rússia, com a criação da Universidade Nacional de Circo e de Artes Variadas, mais conhecida como Escola de Circo de Moscou, as artes do circo se desenvolveram, aliadas a métodos esportivos vindos da ginástica. A criação de apresentações originais, além da presença de diretores teatrais e de coreógrafos, culminou no desenvolvimento de técnicas inovadoras, aparelhos e números totalmente novos. Em 1950, notava-se no Ocidente uma visível superioridade das performances do Circo de Moscou (nome genérico adotado por todos os circos soviéticos que saiam em turnês internacionais).

O circo novo, ou circo contemporâneo, apareceu nos anos 1970 como um gênero circense fortemente teatralizado e dançado, com um inevitável destaque para os corpos de seus artistas e o universo poético criado por eles; as suspensões ganharam ainda mais destaque, por estarem mais ligados a um movimento orgânico do que ginástico. As companhias de maior destaque que inauguraram o circo novo são a Archaos, o Cirque Plume e, em 1995, o espetáculo "Le cri du caméleon”, sob direção e coreografia de Josef Nadj, do Centro Nacional de Arts du Cirque. ${ }^{29}$

A criação de escolas de circo nos anos 1970, em contraponto às tradicionais famílias circenses, inaugurou esse momento de profunda mudança nas artes do circo, concomitante à criação de novos números permeados pelo desenvolvimento tecnológico de novos aparelhos e elementos aéreos, no qual os elementos de teatro, música e dança se tornam parte constituinte das artes do circo.

Em 1974, Annie Fratellini (1932-1997), herdeira de uma dinastia de palhaços tradicionais de circo, e Alex Gruss Jr. (1944-), herdeiro da última dinastia de equestres franceses, criaram em Paris as duas primeiras escolas de circo inspiradas no modelo russo. Os alunos dessas escolas atuavam em departamentos performáticos que nada mais eram que circos, cujos objetivos estavam além da técnica. Eles se uniram na criação de um espetáculo múltiplo, em um modelo tradicional, porém com profunda mudança, Annie Fratellini com o Nouveau Cirque de Paris, e Alexis Gruss, que nomeou seu circo como Le Cirque à l'Anciene ${ }^{30}$. Em 1975, o príncipe Rainer de Mônaco criou o Festival Internacional de Circo de Montecarlo, que está em pleno funcionamento até hoje e se tornou para o mundo do circo um evento semelhante ao que o Oscar representa para a indústria do cinema. Em 1977, surgiu em

\footnotetext{
29 Disponível em: <http://www.lemonde.fr/culture/article/2006/01/06/jean-michel-guy-le-cirque-vit-le-plusimportant-phenomene-de-son-histoire_728151_3246.html\#Uvku3urPMpZwjood.99>. Acesso em: 12 out. 2016.

${ }^{30} \mathrm{O}$ Circo à moda antiga.
} 
Paris o Festival Mondial du Cirque de Demain ${ }^{31}$, criado para mostrar e promover a nova geração de artistas de circo, a maioria deles treinado em escolas de circo. Bernard Paul e André Heller criaram o Circo Roncalli na Alemanha no mesmo ano, aproximando o público a um espetáculo mais intimista e menos extravagante do que os circos que herdaram as grandes proporções americanas.

Nos anos de 1980, houve a criação, em Montreal, da École National du Cirque por Guy Caron, que também foi o primeiro diretor artístico do inovador Cirque du Soleil, criado a partir dessa escola por Guy Laliberté em 1984. Nos Estados Unidos, em 1977, Paul Binder e Michael Christensen, que haviam trabalhado no Nouveau Cirque de Paris de Annie Fratellini, criaram o Big Apple Circus. Na Austrália, Jane Mullet criou o Flying Fruit Fly Circus e, depois de assistir aos espetáculos "Saltimbanco" e "Nouvelle experience", ambos do Cirque du Soleil no ano de 1992, inaugurou a escola profissionalizante NICA (National Institute of Circus Arts), que graduou sua primeira turma de artistas circenses em 2003.

Em janeiro de 1986, depois de encerrar as atividades do Circo Bidon, Pierrot Bidon e Martine Leroy decidiram reunir numa mesma lona artistas de rua e circo, como nos primórdios do circo moderno. Criaram a companhia Archaos - cirque de caractère, que se destacou por suas criações coletivas, tendo sido Franco Dragonne o primeiro diretor, seguido de Michel Dallaire, que encenou os primeiros espetáculos: “Le chapiteau de cordes" (1987) et "Le chapiteau de cordes 2" (1988). ${ }^{32}$

A própria companhia descreve o espetáculo "Le chapiteau de cordes" como:

[...] uma teia de aranha gigante. O espectador está dentro e fora, onde sua imaginação não tem limites. Neste espaço os "personagens" de Archaos expressam a sobrevivência diária dos excluídos da sociedade de consumo envolvendo-se em brigas com motosserras, moedores, soldadores, repelindo $\mathrm{o}$ ataque de caminhões loucos. [...] $\mathrm{O}$ circo se entrelaça em contrastes intermináveis. A violência, o riso, a agressão, poesia, escárnio, nesta estética do mundo moderno. [...] $\mathrm{O}$ espaço da pista rapidamente se torna inadequado para o conteúdo. É um espetáculo que quebra o círculo, é quadrado cheio de veículos motorizados (motocicletas, carros, caminhões). Apresenta um processo de dramatização que permanece incerto, gerando tensões que provocam ações, sons, luzes e odores. São descontinuidades múltiplas, que deixam para o espectador a responsabilidade de construir um caminho significativo. ${ }^{33}$

\footnotetext{
${ }^{31}$ Festival Mundial do Circo do Amanhã.

${ }^{32}$ Disponível em: <http://fresques.ina.fr/en-scenes/fiche-media/Scenes00542/archaos-cirque-de-caractere.html>. Acesso em: 12 out. 2016.

${ }^{33}$ Disponível em: <http://www.archaos.fr/creation_archaos/le-chapiteau-de-cordes/>. Acesso em: 12 out. 2016.
} 
O espetáculo "Le chapiteau de cordes" já apresenta no seu título dois elementos circenses que interessam neste estudo de suspensão: a palavra chapiteau, que é o espaço físico do circo tradicional, a lona, onde tudo acontece, onde tudo é possível; e as cordas, que mais do que um elemento aéreo, são materiais muito comuns no circo. Além de ter uma estética quase que punk, o espetáculo fugia completamente ao que já havia sido produzido nos circos, incluindo a presença marcante das acrobacias aéreas, em números que não eram apenas técnicos ou virtuosos, e que contextualizavam a proposta de uma narrativa não linear. Também se criou uma linguagem completamente relacionada à suspensão de corpos e elementos de cena, pela qual um ator era içado por uma motosserra presa a um motor de suspensão, chegando até a elevar uma motocicleta com um de ator preso a ela. As materialidades da cena são destacadas e literalmente suspensas, se desconstruindo a todo momento.

Segundo Jean Michel Guy (2001, p. 10), o circo novo se distingue do circo moderno pela "singularidade de suas obras, a acuidade de seus questionamentos, a energia que ele transmite às outras artes do espetáculo, já um pouco sem fôlego. Longe do puro divertimento, ele ousa pôr sobre o mundo um olhar crítico, dando-lhe um novo encanto a partir de emoções imprevistas".

Em 1993, surgiu o coletivo Les Arts Sauts, que reuniu onze acrobatas de diferentes escolas de circo da França, como a École de Trapèze Jean Palacy e a École de Cirque Annie Fratellini. Eles se intitulavam representantes desse "novo circo francês", caracterizado pela inexistência de animais. Como primeira criação, o grupo produziu um espetáculo numa estrutura de metal de vinte metros de altura, na qual os artistas se reagrupavam para formar um espetáculo aéreo dedicado especialmente ao trapézio. ${ }^{34}$

Como modelo de cultura e de técnica relacionada ao circo, o Cirque du Soleil se destaca não só pelas suas proporções gigantescas, mas por se estabelecer como uma grande empresa de circo. Concebeu uma forma de fazer circo, ligada ao novo circo, carregada de uma estética própria, que foi amplamente replicada. O Cirque du Soleil realizou uma extensa divulgação dos seus trabalhos, não só pelo fato de ter diversas lonas espalhadas pelo mundo, como também por produzir um material videográfico viral, anterior ainda ao Youtube, que modificou a forma de divulgação das técnicas e espetáculos circenses. Também dele se

\footnotetext{
${ }^{34}$ Disponível em: <http://www1.folha.uol.com.br/fsp/1997/9/11/ilustrada/15.html>. Acesso em: 12 out. 2016.
} 
desenvolveram aparelhos aéreos e técnicas, tanto no aspecto de resgate de conhecimentos que não se viam há muito tempo, como percursor de novas formas de suspensão, novos materiais e tecnologias.

O aparelho aéreo Tecido (Aerial Silk), que é também uma técnica recente nas artes do circo, mas largamente divulgada, foi criada por Gérard Fasoli ${ }^{35}$ na França, no começo dos anos 1990, e durante algum tempo foi um aparelho conhecido pelo nome "cordas Fasoli". Um dos primeiros números de Tecido foi realizado por sua aluna Isabelle Vaudelle que, em 1995, e ganhou medalha de prata no Festival Mondial du Cirque de Demain. O seu número chamado "contorsion air et soie" foi desenvolvido e redirigido em 1996 por André Simard, para o espetáculo Quidam do Cirque du Soleil, tornando-se um dos principais números aéreos do espetáculo. Esse aparelho aéreo foi considerado um exemplo de inovação tecnológica e coreográfica das artes do circo, ou do chamado novo circo.

A crença de que o Tecido é uma extensão do trabalho de corda lisa pode ser observada na semelhança das técnicas. Na evolução de ambas as técnicas, os movimentos de suspensão na corda influenciaram a criação de muitos truques no Tecido, e o mesmo acontece no sentido oposto. A difusão da técnica do Tecido na atualidade pode ser explicada pela facilidade de aprendizagem, pois o material se molda ao corpo e se adapta à postura de quem a pratica.

Figura 14 - Isabelle Vaudelle no espetáculo Quidam do Cirque du Soleil

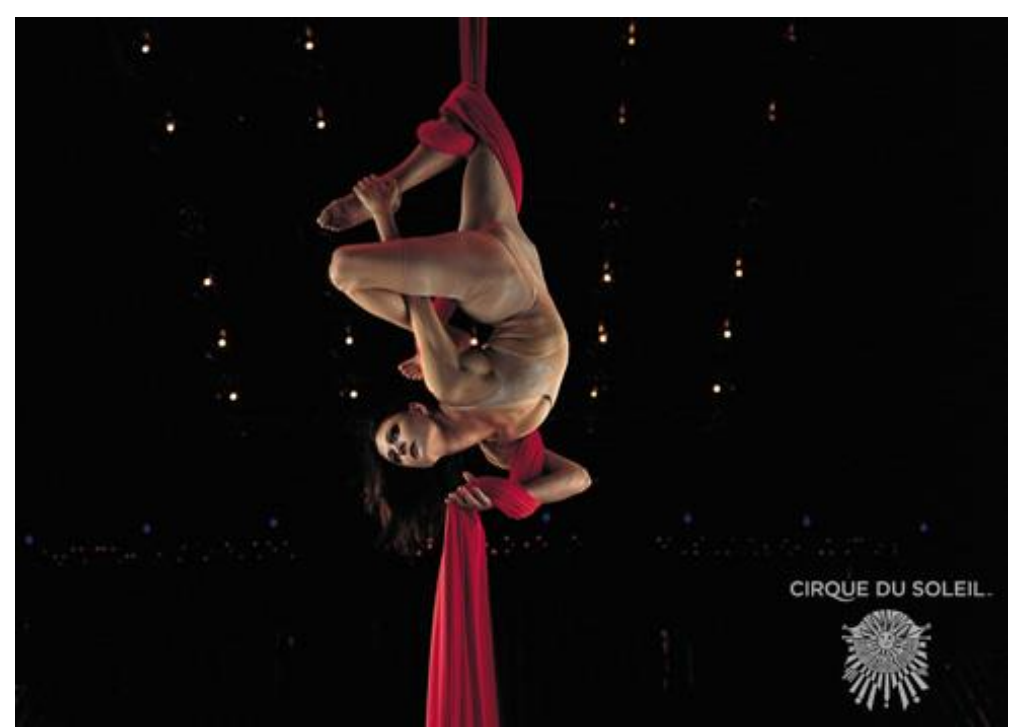

Fonte e foto: Cirque du Soleil.

\footnotetext{
${ }^{35}$ Gérard Fasoli é um ex-treinador de alto nível trampolim acrobatico, e atualmente é diretor do Centre National du Cirque (CNAC), na França.
} 
Há pesquisas que aproximam a técnica do Tecido de alguns desenhos orientais de performances com grandes panos, durante as festividades dos imperadores da China, por volta do ano de 600 d.C. Também há relatos de que nas décadas de 1920 e 1930, em Berlim (Alemanha), alguns artistas de cabaré realizaram movimentos em tecidos que pareciam ser cortinas (BORTOLETO; CALÇA, 2007a, p. 73-89).

As produções datadas dos anos de 1990 até hoje são responsáveis por apontar questões ligadas ao equilíbrio e ao espaço, que nos permitem observar o encontro entre o fantástico, o inesperado e a tecnologia. Atualmente as virtuoses circenses estão presentes tanto nas ações, no corpo e no movimento dos atores-acrobatas, como nos diversos materiais que constituem cenários, aparelhos e indumentárias, e nas ideias e estéticas presentes nos espetáculos que utilizam o circo como forma de comunicação.

As artes aéreas do circo possuem materialidades objetivas e subjetivas muito particulares e, nas diversas formas de habitar o espaço da cena, mostram mais do que figuras desafiando a gravidade: provocam sensações e evidenciam ao espectador a presença de um espaço vazio.

A ação de voar não é hoje mais uma novidade, e o que fascina e encanta são as formas, dimensões e proporções com que esses voos acontecem, e até mesmo a distância física entre quem voa e quem observa, seja de longe e de forma contemplativa, seja próxima e intimamente participativa, tangível ou virtual.

A chamada ruptura provocada pela emergência do novo circo, ou circo contemporâneo, mais se assemelha a uma colaboração e uma conexão com o teatro, música e dança do que uma forma completamente inovadora de estar na cena. As multiplicidades de investigações reelaboram e recuperam modos de fazer; o empréstimo de estéticas e características nas diversas formas de reinventar os espaços estão impregnadas de histórias e estórias. E as artes do circo, que invadem teatros, ruas, fachadas de prédios, e tantos outros lugares, não só carregam uma tradição e uma popularidade inerente a esse modo de habitar a cena, mas também constroem uma organização herdada das famílias circenses, que são as produções coletivas e espetáculos que inconscientemente alcançam voos inesperados e redefinem as noções de trupe circense. 


\section{COMPANHIA CÊNICA NAU DE ÍCAROS: HISTÓRIAS DE DESENHOS NO ESPAÇO}

Explorando os mares percorridos pela embarcação chamada Nau de Ícaros, observamos que os caminhos escolhidos são um reflexo de uma forma de fazer teatro neste tempo e neste espaço. Desde a criação da companhia Cênica Nau de Ícaros nos anos 90, até hoje, as mudanças históricas e materiais possibilitaram aos seus artistas marinheiros chegarem a um lugar muito particular. São mais de vinte anos construindo espaços com características próprias e uma presença particular.

Como artista e parte integrante desse caminho, pude observar, durante doze anos, de que forma os princípios do circo e seus elementos aéreos contribuíram para delinear as características dessa companhia. Investiguei a forma de habitar o espaço através do histórico da Companhia, suas escolhas cênicas e cenográficas, que apontam uma multiplicidade de elementos, técnicas corporais e cênicas que o circo agrega, e que possibilitam uma suspensão física e onírica da cena. Ouso dizer que a história da Companhia Cênica Nau de Ícaros começa com um profundo desejo pelo circo.

Os espetáculos produzidos pela companhia, e que serão apresentados neste capítulo, possuem temas que transitam entre o fantástico, o divino, o carnal, o poético e o universal. Como um estudo de espaço e desenho da cena, os momentos escolhidos foram divididos em "lugares" percorridos pela companhia: o primeiro voo, que retrata os primeiros espetáculos da Companhia; o lugar físico, que retrata o momento que a Companhia criou um espaço de fomento e trocas culturais na cidade, o Galpão Nau de Ícaros, e os espetáculos desenvolvidos nesse espaço; o lugar dos sonhos, que retrata o espetáculo Fronteiras; o lugar imaginado, que retrata o espetáculo Cidade dos sonhos; o lugar do sagrado, que retrata o espetáculo De um lugar para o outro; e o lugar no mundo, que retrata o espetáculo Menor que o mundo. $\mathrm{O}$ espetáculo Tirando os pés do chão será tratado em um próximo capítulo, no formato de gênese, e se apresenta como o lugar do amor.

A história dessa Companhia, o percurso de artistas exploradores, os diversos espaços da cena e suas produções ao longo dos anos serão tratados aqui como "Projeto Nau de Ícaros". Intitula-se como projeto porque sempre foram os desejos de cada um dos integrantes que impulsionaram a realização de todas as produções, um caminho repleto de ideias e planos. Expõe não só uma reunião de diversas produções artísticas, mas identifica um modo de pensar 
e fazer arte, uma forma de se relacionar com o meio, seja ele físico, arquitetônico, corporal ou virtual. $^{36}$

Ao descrever a relação espacial estabelecida pela Companhia, um ponto importante a ser enfatizado é o vínculo entre teatralidade e espaço. Nas reflexões de Josette Féral, ela identificou a condição de teatralidade como um espaço distinguido e criado pelo olhar do espectador, e aqui vamos trazer um olhar que faz emergir a própria teatralidade da Companhia Cênica Nau de Ícaros (FÉRAL, 2002, p. 97). Como observadora, o meu olhar que antes era interno, incorporado ao íntimo das produções da Companhia, agora contempla e me visto como um espectador diferenciado, que possui segredos a serem revelados.

Ao tratar do espaço da cena, também se observa a teatralidade da Companhia Cênica Nau de Ícaros, não como propriedade, mas sim como diz Féral (1988, p. 86), “um processo que indica sujeitos em processo" 37 , que esclarece os modos de estar na cena por meio da própria história contada. A história do processo do "Projeto Nau de Ícaros" está inserida na história do circo na cidade de São Paulo que, aqui evidenciada, cria por intermédio do imaginário desenvolvido e absorvido uma relação de presença e materialidade na cena, da qual emerge uma ação repleta de possibilidades que transcendem olhares e espaços.

O circo no Brasil tem sua origem nas famílias circenses que chegaram da América e da Europa e está relacionada ao grupo de indivíduos que nasceram e tiveram sua formação associada ao espaço físico e subjetivo do circo. O convívio no espaço social do circo cria uma unidade que define o espaço dramático, presente na vida e na formação desses artistas. $\mathrm{O}$ circo tradicional brasileiro como espetáculo é retrato de um modo de vida, pois o espaço da lona é um lugar onde o trabalho, a família e as práticas artísticas se misturam como reflexo do contexto familiar.

Na história das famílias circenses no Brasil, a relação espacial está intimamente ligada à forma como os circenses interagiam com a população dos lugares aonde os circos itinerantes chegavam, os indivíduos pertencentes ao circo se intitulavam os de "dentro" da lona, e a

\footnotetext{
36 "Do latim virtus ("força" ou "virtude"), virtual é um adjectivo que, no seu sentido original, faz referência àquilo que tem a virtude de produzir um efeito apesar de não o produzir verdadeiramente. No entanto, o conceito está actualmente associado àquilo que tem existência aparente e não propriamente real nem física." (Conceito de virtual. Disponível em: <http://conceito.de/virtual\#ixzz3x2HyXjMT>. Acesso em: 15 dez. 2015).

${ }^{37}$ No original: "Plus qu'une proprieté, la théâtralité apparaît done a cette phase-ci de notre réflexion comme un processus qui rèpere de sujets en procès: regardé-regardant." (nossa tradução).
} 
população e espectadores, os de "fora", a partir de uma distinção em relação ao espaço físico da lona, que por sinal é, ao mesmo tempo, espaço social e espaço da cena.

A constituição do circo-família é resultado de um processo de sociabilização, de formação e aprendizagem ligada a uma organização de trabalho (SILVA, ABREU, 2009, p. 30). Um dos objetivos era a manutenção e preservação do circo como grupo e espaço onde a tradição da cultura circense se ligava a uma memória familiar e onde a própria lógica familiar e de trabalho estava associada a transmissão oral dos saberes dentro desse espaço físico, social, dramático e familiar. Os grupos de circo que se constituíram a partir das formações em escolas ou circo-escolas se caracterizam por ter a estética circense como principal elemento de relação espacial, mas o espaço da cena não é o mesmo espaço familiar e grupal, o espaço dramático é trabalhado de forma distinta à dos circos-família.

Em São Paulo, os grupos de circo que se constituíram a partir das formações em escolas ou circo-escolas, como é o caso da Companhia Cênica Nau de Ïcaros, se caracterizam por ter o circo como estética e principal elemento de relação espacial, porém o espaço da cena não é o mesmo espaço familiar e grupal, é trabalhado de forma distinta ao dos circos-família.

A primeira escola de circo no Brasil foi criada em 1978: a Academia Piolin de Artes Circenses, localizada em São Paulo, surge como segmento de uma importante mudança na história das artes do circo no Brasil:

Quando as primeiras escolas de circo surgiram no Brasil, um dos principais objetivos que motivaram aqueles profissionais, na sua maioria constituída de artistas circenses tradicionais, ou seja, que vieram da lona, era dar continuidade à aprendizagem aos filhos dos próprios circenses, que estariam segundo suas justificativas, deixando de aprender essa arte. [...] Os filhos de gente do circo não participavam dessas escolas e os alunos eram pessoas fixas das cidades, vindas dos mais diferentes grupos sociais e com propósitos e objetivos diversos e múltiplos (SILVA, ABREU, 2009, p. 180).

A segunda escola de São Paulo, o Circo Escola Picadeiro, foi aberta em 1984 por José Wilson Leite, em um terreno da Avenida Cidade Jardim, um espaço comum ao circo, pois muitos circos itinerantes em suas passagens pela cidade já tinham montado suas lonas ali. A escola, que ficou por mais de vinte anos naquele espaço, que é hoje o Parque do Povo, atualmente está localizada na cidade de Osasco, São Paulo.

A Companhia Cênica Nau de Ícaros surgiu da reunião de jovens iniciantes nas artes da dança, do teatro e do circo que se encontraram no Circo Escola Picadeiro, no começo dos anos 1990, período em que o grupo Acrobático Fratelli ministrava aulas nessa escola. 
O Acrobático Fratelli representa, no contexto do surgimento das escolas de circo, a primeira geração de circenses na cidade de São Paulo que não nasceram no circo. A produção do grupo ultrapassou a relação do "estar em cena", pois além de realizar espetáculos e números circenses, foi e é até hoje responsável pelo desenvolvimento de aparatos e elementos cenotécnicos que são utilizados por muitos grupos e companhias que têm elementos circenses aéreos em suas produções.

A artista e pesquisadora Isabella Mucci descreve as inovações o grupo Acrobático Fratelli como "apetrechos voadores", nos quais técnicas de alpinismo se misturam ao circo, fazendo com que o grupo, ao longo dos anos, se especializasse em grandes produções técnicas, shows ao ar livre e eventos corporativos. O fundador e diretor da companhia, André Caldas, relata que a contribuição do trabalho do Acrobático Fratelli para o circo brasileiro foi o desenvolvimento de equipamentos e acessórios para números e efeitos aéreos. O grupo sempre aprofundou e disseminou os conhecimentos técnicos, ao testar novos materiais e efeitos, gerando uma contribuição técnica vinculada a um espaço aéreo e o desenvolvimento dos equipamentos (principalmente de alpinismo) e também ampliando seu mercado com equipamentos para efeitos de cinema. Os integrantes da primeira formação do Acrobático Fratelli foram Kiko Belucci, Kiko Caldas, Paulo Vasconcelos, André Caldas, Luis Ramalho, Guto Vasconcelos, Felipe Matsumoto e Marcelo Castro (MUCCI, 2013, p. 53).

A Companhia Cênica Nau de Ícaros foi criada no ano de 1992, dentro do espaço da lona do Circo Escola Picadeiro. Além da criação e produção de inúmeros espetáculos, o "Projeto Nau de Ícaros" foi responsável pela formação e gestão de um outro espaço de investigação e pesquisa, onde se promoveu um intercâmbio de experiências com diversos artistas, grupos, diretores e público em geral, e como consequência contribuiu para o nascimento de novas companhias em diversas áreas. Consequentemente, possibilitou ampliar o modo de estar em cena daqueles que por lá passaram, ao ocupar os muitos espaços possíveis, tradicionais como o palco italiano, arena, rua e até mesmo verticalizando a arquitetura como espaço da cena.

Poderíamos dizer que a Companhia se coloca no espaço da cena misturando circo, dança e teatro, mas existem nuances maiores que não permitem simplificar somente como uma mistura de artes. A Companhia se situa na combinação do lugar onde o circo não alcança, que a dança não atinge e no espaço que o teatro não chega, no exato ponto onde os três se complementam. 
No Circo Escola Picadeiro, as pessoas que faziam parte da primeira formação da Companhia Cênica Nau de Ícaros tinham certamente aptidões especiais, pois até hoje estão produzindo artisticamente e todos os dez integrantes que inauguraram os trabalhos da Companhia atuam dentro do que podemos chamar de arte performática. Eram jovens artistas, cada um com alguma aptidão a oferecer; o físico e as materialidades ligadas a um corpo que se desloca pelo espaço reunia aquelas pessoas. Na sua primeira formação estavam Fernando Sampaio, Erica Stoppel, Juliana Neves, Alex Marinho, Patrícia Horta Lemos, Margarida Ribeiro, Luciana Cestari, Marco Vettore, Mônica Alla e Paola Musatti. Também passaram por esse momento inicial da formação da Companhia Lincoln Rollim e Vera Abbud. Ao longo de todos os anos, diversas estórias foram contadas e muitos espaços foram explorados, mas um objetivo comum, enquanto artistas, público e integrantes de uma sociedade, sempre caracterizou o "Projeto Nau de Ícaros": uma vontade de lançar um olhar contemporâneo para a cultura popular brasileira, na qual o circo se apresenta como parte integrante e difusora dessa cultura.

Em visita ao Centro de Memória do $\mathrm{Circo}^{38}$, localizado no Largo do Paiçandu, em São Paulo, essa característica do circo como difusor de cultura fica clara, ao se ouvirem histórias sobre o lugar onde está localizado esse museu. O Largo do Paiçandu, no começo do século $\mathrm{XX}$, era o principal ponto de parada dos circos que chegavam à cidade. Lá eles montavam as suas lonas e diversos espetáculos eram realizados. Uma imensa troca de informações e difusão de artistas, não só circenses, mas de diversas áreas, acompanhava esses acontecimentos. Naquela época, a comunicação era pessoal e os artistas se encontravam naquele local, onde o público era formado e a cultura disseminada. Essa importância que os circos tinham, de espalhar e comunicar a cultura, de levar essa cultura junto com sua itinerância, é uma herança que está presente até hoje nas próprias ações cênicas realizadas por artistas que possuem o chamado "espírito circense". Se antes era uma "herança genética", pois os conhecimentos circenses eram passados de pais para filhos, hoje se tornaram uma herança cultural, enraizada nas ações e signos trazidos pelo circo e companhias que trabalham com elementos circenses.

É esse "espírito circense" que o "Projeto Nau de Ícaros" carrega desde a sua origem e que faz parte integrante de uma teatralidade identificada em suas ações cênicas.

\footnotetext{
${ }^{38}$ É o primeiro centro de memória do Brasil consagrado exclusivamente ao circo e suas artes. Disponível em: <www.prefeitura.sp.gov.br/cidade/secretarias/cultura/patrimonio_historico/memoria_do_circo/acervo/index.ph $\mathrm{p} ? \mathrm{p}=7147>$. Acesso em: 05 jan. 2015.
} 
A experiência teatral proposta pela Companhia Cênica Nau de Ícaros está intimamente relacionada com a teatralidade e performatividade presentes no espaço da cena, de formas distintas em cada uma de suas produções. Cada processo de criação delimita uma realidade diferente e uma teatralidade diferente, e a partir do momento em que o espaço da cena proposto se faz por meio de ações e de presença, esse espaço tem a possibilidade de ser constantemente modificado durante o ato cênico.

Os espetáculos realizados ao longo do processo do "Projeto Nau de Ícaros" caracterizam uma forma de habitar o espaço da cena, com traços que compõem distintas teatralidades referentes a cada produção cênica. A performatividade presente na cena composta pelos atores e suas ações se misturam às técnicas e aparelhos aéreos circenses e, levando em consideração que toda a teatralidade possui um dado de performatividade, tensionam a cena. Essa tensão é desenvolvida e criada pelas diversas características inerentes a cada criação da Companhia, e a presença dos elementos circenses na cena, principalmente os aéreos, criam uma suspensão e um risco ligado à teatralidade e à performatividade.

Nos primeiros momentos da Companhia, no princípio da reunião daqueles artistas tão diversos, a suspensão e o risco estavam aliados ao desafio de que o treino do circo deixaria de ter o caráter de prática, passaria a ser ensaio, e no questionamento: ensaio para quê? Eles começaram a se preparar para uma possível apresentação. Criou-se um objetivo em comum, que era se apresentar na Organização Social Santa Fé, no dia 8 de outubro de 1992, data que foi instituída como a primeira apresentação da Companhia Cênica Nau de Ícaros, e ponto de partida da história da Companhia.

A primeira apresentação foi feita ao ar livre e havia um certo improviso quanto às questões de espaço da cena e figurinos. Na segunda $f u n c ̧ a o^{39}$, que foi em uma quadra, o espaço da cena permitiu que a Companhia começasse a pensar em diversos detalhes. Essa nova disposição espacial da cena fez emergir preocupações ligadas a um espaço em que eles não tinham a menor experiência e surgiu um cuidado com as entradas e saídas, com a maquiagem e a indumentária. Pensando na forma como os atores-acrobatas iriam aparecer e como podiam trabalhar com uma cena que estava "livre", surgiram questões ligadas a um espaço que precisava ser preenchido com os materiais que os próprios atores traziam, através das acrobacias e diversos números de circo.

\footnotetext{
${ }^{39}$ Função é o nome dado para cada sessão ou apresentação no circo.
} 
Isso também aconteceu porque os ensaios aconteciam dentro do circo, onde se tinha um espaço definido pelos quatro mastros e com pontos aéreos determinados. No Circo Escola Picadeiro o espaço era composto de picadeiro e palco, e os pontos de suspensão tinham que ser ancorados somente na cúpula do circo ou no máximo numa caranguejeira de um mastro.

A pesquisadora Erminia Silva utiliza o termo caranguejeira na descrição do espaço da cena e da forma como se prendiam roldanas, das quais desciam as cordas para os números aéreos nos circos brasileiros de pau-a-pique, durante a segunda metade do século XIX e início do XX.

No centro do terreno cravava-se uma estaca, na qual se amarrava um fio de barbante com uma medida de 13 metros, demarcando o espaço onde seria $o$ picadeiro ou arena. [...] ia-se construindo um círculo, no qual eram fincadas madeiras, dispostas lado a lado, que eram cortadas no mato, doadas por ou compradas de fazendeiros da região. Essas madeiras eram amarradas ou pregadas, e delas saía uma estrutura para sustentar lances de bancadas suportadas por cruzetas, que formariam o que normalmente se denomina geral ou arquibancadas. No centro da arena instalava-se o mastro de eucalipto, jacarandá ou ipê, em cujo topo era colocado um travessão formando meio T, chamado escandalosa ou caranguejeira (SILVA, 2007, p. 87).

Os caminhos percorridos em mais de vinte anos pela Companhia sugerem uma contribuição para a história do teatro de grupo na cidade de São Paulo, além de fazer parte de uma geração de artistas que romperam com alguns modos de fazer teatro na cidade de São Paulo.

Eliene Costa (1999), que analisou alguns grupos nas décadas de 80 e 90, incluindo a Companhia Cênica Nau de Ícaros, fala sobre a utilização de elementos físicos e líricos do circo, sobre a renovação da cena brasileira e o rompimento do espaço do palco tradicional italiano, bem como características referentes a um espetáculo visual, ligado a imagem, performance e festa popular.

\subsection{O primeiro voo}

O primeiro espetáculo, que lançou o nome da Companhia Cênica Nau de Ícaros, nasceu da construção de um roteiro e de uma discussão sobre formatos de espetáculos e 
dramaturgias distintas e possíveis, junto com o diretor Sérgio Sálvia Coelho ${ }^{40}$. A necessidade de formalizar o que a companhia vinha experimentando, somado a uma vivência de um dos integrantes, Marco Vettore ${ }^{41}$ no Centro de Pesquisa Teatral (CPT) dirigido por Antunes Filho $^{42}$, reflete uma pesquisa de cena comum da época, do final dos anos 1980, que é o cartoon invadindo a dramaturgia do teatro, a presença de uma estética de história em quadrinhos na cena teatral.

Na observação do contexto histórico e na busca das referências em que a Companhia se inspirava, e destacando uma estética particular múltipla utilizando elementos circenses, chegamos à importante produção paulista do espetáculo Ubu folias physicas, pathaphysicas $e$ musicais, do Teatro do Ornitorrinco, que estreou em março de 1985, no Teatro João Caetano, em São Paulo. O texto do espetáculo "ganhou o caráter episódico e fragmentado de uma história em quadrinhos sobre a aventura do anti-herói” (VACCARI, 2008, p. 120), principalmente pelo diálogo do teatro com o circo.

O diretor Cacá Rosset realizou um espetáculo inspirado no circo e music-hall, e decidiu buscar no circo a inspiração estilística para seu trabalho, com o intuito de fazer um teatro nada convencional para a época. Utilizando referências da obra Le grand magique circus, de Jérôme Savary, teve a presença de ex-alunos da Academia Piolin e foi também ensaiado no espaço da lona do Circo-Escola Picadeiro. O dono da escola, José Wilson Leite, atuava como ator e diretor de técnicas circenses no espetáculo (MATHEUS, 2016, p. 214).

\footnotetext{
${ }^{40}$ Sérgio Salvia Coelho é diretor de teatro, professor de história do teatro e crítico de teatro brasileiro, do jornal Folha de S.Paulo.

${ }^{41}$ Entrevista de Marco Vettore, em 31 de agosto de 2016.

${ }^{42}$ Em 1977, Antunes Filho, já reconhecido diretor, inicia uma pesquisa cênica sobre Macunaíma, de Mário de Andrade (1893-1945). Reunindo um conjunto de jovens atores e sediado no Teatro São Pedro, após longo trabalho de criação coletiva, nasce a encenação, estreada em setembro de 1978. Saudada como impactante, torna-se um marco nas artes cênicas brasileiras. O grupo recém-nascido denomina-se Pau Brasil; e assim permanece por dois anos. Macunaíma faz 876 apresentações, no Brasil e no exterior, e figura no repertório até 1987. O sucesso nacional e internacional, as muitas viagens e crises no sistema de cooperativa obrigam a mudanças e o elenco passa a ser conhecido como Grupo Macunaíma, depois de 1980. No ano seguinte, já renovado, estreia Nelson Rodrigues - o eterno retorno, baseado em quatro textos do autor. Nesse formato, ou na abreviação Nelson 2 Rodrigues, faz 231 sessões, excursionando também pelo exterior, até 1985. A complexidade do empreendimento e as constantes viagens obrigam a um redimensionamento da infraestrutura e condições materiais, e exigem o aprofundamento da pesquisa contínua. Transferido para o Sesc São Paulo, o grupo encontra tais condições, através da fundação do Centro de Pesquisa Teatral, CPT, em 1982. O Centro nasce para desenvolver e ampliar as propostas do Sesc e do grupo, incrementar a logística de infraestrutura, uma vez que as excursões obrigam constantes remontagens e modificações no elenco. Confundem-se, desde então, as atividades do Grupo Macunaíma com as do CPT. (Disponível em: <http://enciclopedia.itaucultural.org.br/grupo401300/cpt-centro-de-pesquisa-de-teatro〉. Acesso em 20 out. 2016).
} 
Assim como o circo vai para o teatro, o teatro invade o circo, atores se interessam por ter no seu corpo as possibilidades de um artista circenses. Nesse contexto do final dos anos 1980 e começo dos 1990, inspirados pelo Teatro do Ornitorrinco, diversas companhias teatrais e circenses surgem dentro do Circo-Escola Picadeiro, dentre elas a Companhia Cênica Nau de Ícaros.

Foi na formalização do roteiro para o primeiro espetáculo, o Nau de Ícaros, que a Companhia também lançou o seu nome, no ano de 1992. Nessa formação da identidade da Companhia, e participando de um contexto teatral da época, uma preocupação de como ocupar a cidade fez com que o espetáculo ficasse seis meses em cartaz dentro do Circo-Escola Picadeiro, e depois fosse adaptado para o teatro, estreando no Teatro Paulo Eiró, em abril de 1993, e em maio, no Teatro João Caetano.

Figura 15 - Reportagem sobre grupos que trabalham elementos de circo

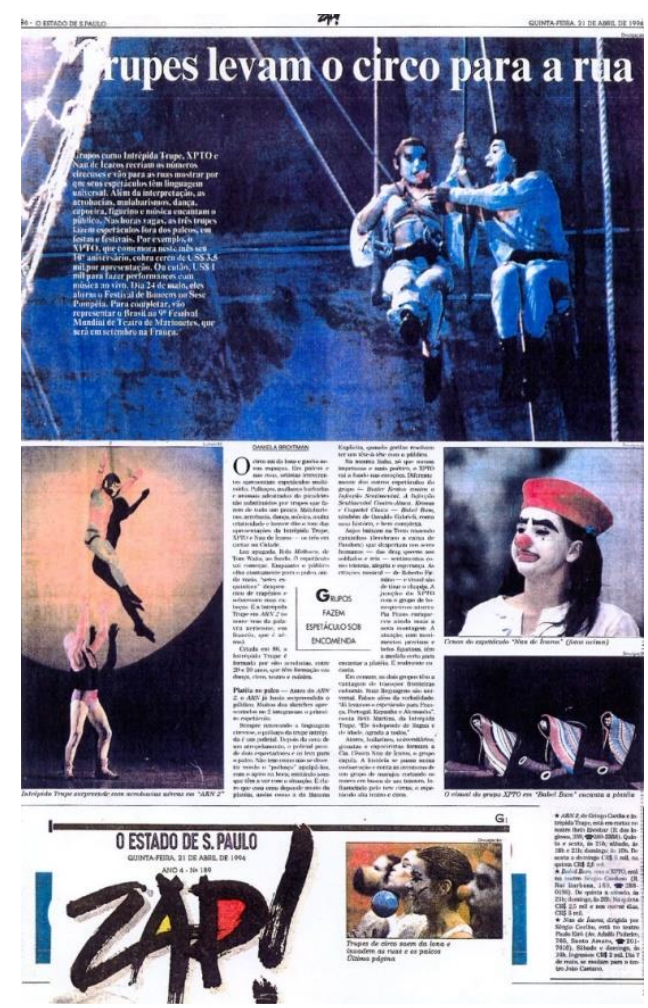

Fonte: Companhia Cênica Nau de Ícaros (O Estado de S.Paulo, de 21 abr. 1993).

Na reportagem de abril de 1993, a Companhia Cênica Nau de Ícaros, com o espetáculo Nau de Ícaros, é citada como uma das trupes que levam o circo para fora do espaço tradicional da lona, para as ruas e teatros, numa relação de expansão do espaço da cena. Junto 


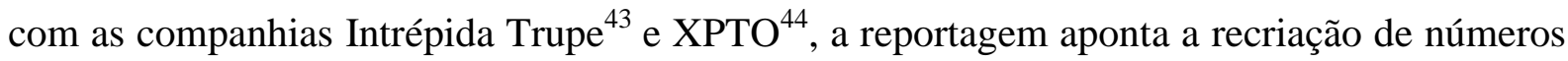
circenses e exemplifica uma universalidade dos espetáculos, através de materialidades como acrobacias, dança, capoeira, malabarismos, figurinos e música. Ao narrar o espetáculo ARN2, da Intrépida Trupe, a reportagem ainda cita a presença de um palco vazio, onde despencam trapézios, e explica que o nome do espetáculo é inspirado na palavra aérienne, aéreo em francês. Todos esses elementos da uma cena suspensa e um espaço aéreo fazem parte de uma geração de artistas e companhias que ampliaram as possibilidades do espaço da cena utilizando os elementos aéreos do circo.

O roteiro do Nau de Ícaros foi construído por todos os integrantes, como se fosse um cruzamento de desejos das diversas pessoas presentes, mas o que fez com que o grupo acontecesse. Foi uma paixão muito grande pelo espaço simbólico que o circo preenchia dentro de cada um, aliada a uma preocupação com os espaços físicos e livres da cidade, e a uma arte de rua vivenciada e observada pela permanência de parte dos integrantes em outros países. Através da utilização de diversos elementos espetaculares, do circo, teatro e dança, a Companhia, desde a sua criação, tinha a preocupação de como provocar as pessoas, para que elas ocupassem os espaços públicos da cidade.

As experiências de cada um, aliadas à vivência de estar embaixo de uma lona, que é um espaço que permite passar calor, frio, vento, chuva, uma estrutura instável, jogava os integrantes da Companhia de volta à cidade, ao espaço livre da cidade e suas muitas possibilidades.

\footnotetext{
${ }^{43}$ Existente há 30 anos, a Intrépida Trupe começou nas lonas do Circo Voador, situado no Arpoador, Rio de Janeiro. Em 1986 nasceu para representar o Brasil na Copa do Mundo de Guadalajara, no México. O grupo revolucionou o circo no Brasil, mesclando as artes circenses com o teatro e a dança. Com mais de 20 espetáculos produzidos, dentre eles: Intrépida Trupe (1988); ARN (1991); ARN 2 (1994); Kab-ooo-M! (1995); IntrepiDEZ (1996); Kronos (1998); Flap! (2001); Sonhos de Einstein (2003); 1000 tempos (2004); Metegol (2006); Noites Intrépidas (2009); Preciosa Idade (2009); Coleções (2009); Sonhos de Einstein (remontagem) (2009); Gol a Gol (2010); Domingos Intrépidos (2010); Uma Onda No Ar (2011); Ao Vento (2012); De palhaço e louco... (2012); O Barão nas Árvores (2012); A Tempo (2015); À Deriva (2016); Cidades Flutuantes (2016). (Disponível em: <https://www.facebook.com/intrepida.trupe/>. Acesso em: 25 out. 2016).

${ }^{44}$ Espetáculo Babel Bum, junto com a companhia Pia Fraus. O grupo XPTO foi fundado em 1984, participando na formação de um teatro brasileiro contemporâneo. Tem um histórico expressivo dentro do panorama teatral brasileiro. O trabalho do grupo, caracterizado pela realização de espetáculos com grande apelo visual e musical, vem contribuindo para a formação de um teatro brasileiro contemporâneo. Apresentou-se em diversas capitais brasileiras e também no exterior (Argentina, Uruguai, Venezuela, Colômbia, Espanha, França, Portugal, Iugoslávia e Hong Kong), obtendo sempre grande sucesso de público e de crítica. Recebeu, ao longo de 23 anos de carreira, 40 dos mais importantes prêmios do teatro brasileiro: APCA, Mambembe, Shell, APETESP, Governador do Estado, Fundacen, Coca Cola e Panamco, entre outros. (Disponível em: <https://www.facebook.com/grupo.xpto/about/?ref=page_internal>. Acesso em: 25 out. 2016).
} 
A vivência do circo junto aos tempos naturais do dia, das estações do ano, particulariza o espaço físico embaixo da lona. Quando venta muito, dentro de um circo a dinâmica dos acontecimentos é modificada, e o mesmo acontece quando está muito calor, os ensaios de aéreos não acontecem durante o dia, ou se ensaia muito cedo, ou à noite. Uma tempestade pode simplesmente levar o circo para o chão. A equipe que inaugura a Companhia Cênica Nau de Ícaros passou por diversas situações como essas e isso foi marcante para alguns dos integrantes e o circo se estruturou dentro desses artistas como um mundo muito novo, repleto de tradições e que tinha uma necessidade de ser ritualizado, pois eles lidavam com o risco de vida que o circo apresenta.

Nessa relação de vida e morte, o nome da Companhia Cênica Nau de Ícaros vem como se fosse um alerta aos riscos que é ser artista e se lançar no espaço. A palavra Nau, que significa barco, tem a ver muito com a arquitetura do circo, pois os elementos de engenharia, de composição de um circo, são muito semelhantes aos de um barco. Romanticamente, esses marinheiros parados num porto, num momento de bonança, são pessoas muito habilidosas. São como se fossem circenses, descendo e subindo pelos mastros, puxando cordas, lançando equipamentos, equilibrando objetos. São pessoas com conhecimentos do mar, dos caminhos e da natureza e que poderiam ser saltimbancos que precisam ganhar dinheiro nos portos. Portanto, escolheu-se o nome Nau também com a ideia de que, através do barco, é possível se lançar no desconhecido e adquirir novos conhecimentos. E também a ideia de um barco no mar, como um elemento ligado as emoções.

A palavra Ícaro, além de ter uma associação com o número circense de icários, que é um dos primeiros números que apresentam elementos aéreos e de equilíbrio na origem do circo moderno, tem também se relaciona ao ser mitológico Ícaro, filho de Dédalo, como um aprendiz.

Dentre as várias versões sobre o mito grego de Dédalo e Ícaro, há um aspecto inspirador e determinante, que são os dois pares de asas com penas e cera que Dédalo fez para ele e seu filho Ícaro fugirem da ilha na qual foram aprisionados a mando do Rei Minos: "Minos pode vigiar a terra e o mar, mas não o ar", disse Dédalo, "tentarei este caminho" (BULFINCH, 1999, p. 191).

A lenda grega diz que o Rei Minos prendeu Dédalo, o arquiteto de Creta, e seu filho Ícaro, no labirinto de Creta, pois temia que o arquiteto revelasse os segredos da construção do labirinto. Dédalo teve a ideia de fugir do labirinto, que não tinha teto, pelo céu. Eles construíram asas artificiais com as penas dos pássaros que voavam sobre o labirinto e que 
nele faziam seus ninhos, coladas com cera das abelhas que recolhiam. $\mathrm{O}$ único perigo, segundo Dédalo alertara seu filho, seria a cera derreter, caso a altitude do voo fosse maior, portanto mais próxima do Sol. Ícaro, encantado com a experiência de voar, não atendeu às recomendações do pai e voou em uma altitude superior. Suas asas derreteram e Ícaro caiu no mar, para o desespero de Dédalo, que chorou a morte do filho por toda sua vida.

Figura 16 - Quadro La caída de Ícaro (1636-1638) de Jan Carel van Eyck

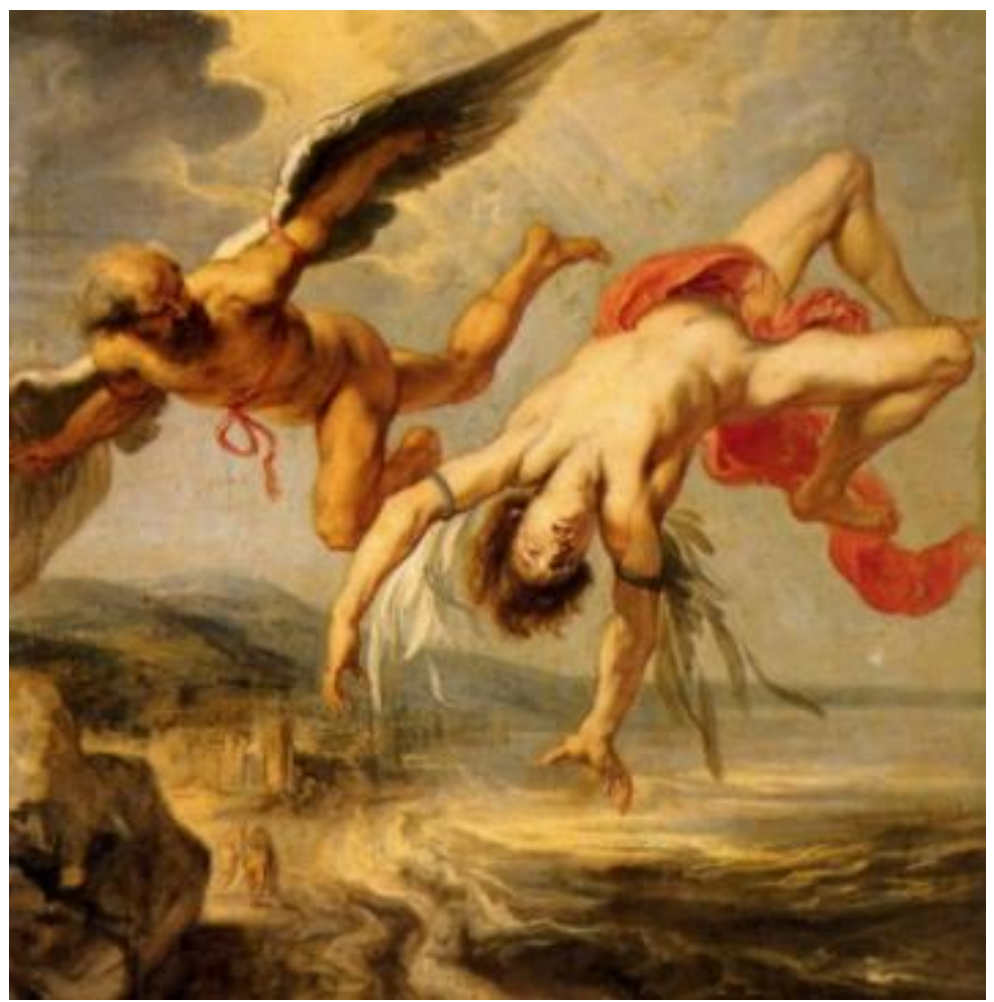

Fonte: Museo Del Prado. ${ }^{45}$

Para a Companhia, a morte mítica na história de Ícaro e Dédalo representava também a morte do conhecimento e a vaidade de alcançar o impossível. Como artistas, os integrantes da Companhia estavam se lançando no desconhecido, no mar e no ar, envolvidos com o eminente risco de vida. Na idealização de adquirir grande conhecimento havia uma atenção para que não achassem que sabiam tudo, ou que ousassem algo antes da hora e acima dos saberes transmitidos pelos seus mestres, o que poderia causar mais que uma morte mítica, uma morte de fato, relacionada aos riscos que o circo oferece. Ou, mesmo ofuscados pelos

45 Disponível em: <https://www.museodelprado.es/coleccion/obra-de-arte/la-caida-de-icaro/2823dc25-398a4d88-a4b2-be314065a62d>. Acesso em: 04 nov. 2016. 
holofotes, a vaidade de se exibir poderia matar a possibilidade de crescerem como artistas. Era uma morte mítica do holofote, e também do conhecimento do artista investigador.

A inspiração para o nome de grupo, que desejava ter uma longa trajetória, associava o termo $\mathrm{Nau}$, que sugere movimento e viagem, trajetória e caminhos, ao par de asas, que é uma materialidade e um elemento ligado à indumentária e ao movimento do corpo no espaço, na ação de voar.

Assim sendo, o espetáculo Nau de Ícaros surgiu da semelhança do artista circense com o navegador, entre os quais há pontos em comum, como a manipulação e utilização de cordas, lonas e mastros, passando por perigos e viagens, riscos e vertigem.

Erminia Silva conta que a formação e história do circense brasileiro estão intimamente ligadas ao "conhecimento e às adaptações tecnológicas utilizadas na construção das estruturas físicas e dos 'aparelhos' [...] a dimensão tecnológica é indissociável da dimensão cultural e revela como este grupo construiu a sua relação de adaptação” (SILVA, 1996, p. 93).

A mesma autora cita que alguns pesquisadores afirmam haver influências no circo de técnicas e aparelhos utilizados pelos marinheiros nos barcos. Por exemplo: a escada de cordas, os nós de marinheiro elaborados e utilizados como segurança e a própria estrutura de cobertura de pano com mastro (estrutura central dos circos e dos barcos). A inspiração da Companhia na vida dos marinheiros e imagens relacionadas, bem como técnicas e aparelhos, se deu também pelo fato dos marinheiros levarem uma vida nômade, como a dos circenses.

As materialidades presentes no espetáculo Nau de Ícaros, no universo dos navegantes e embarcações, estão ligadas à performance e se relacionam a um fazer ou a um desempenhar. Podemos identificar nos estudos performáticos, principalmente segundo as reflexões de Richard Schechner (MOSTAÇO, 2009, p. 16), a mobilização de procedimentos estéticos que aproximam a vida do teatro, criando uma relação material e cultural. A não dependência de uma cultura específica torna alguns aspectos trabalhados pela Companhia como universais e capazes de instigar o espectador, numa relação de recepção e imaginação comuns ao teatro.

Acredita-se que as práticas das artes do circo se originaram (ou se inspiraram) em ações ligadas ao cotidiano e à cultura de forma geral, e se pode considerar que se basearam em fatos reais ou imagens de acontecimentos culturais e cotidianos, e sofreram um tratamento dramatúrgico. No instante em que as ações são identificadas como de marinheiros (o labor e também um fazer cotidiano), o risco, a superação de limites e a performatividade dos números aéreos circenses encaminham o espectador para outro mundo, que não está dentro de um 
navio, mas dentro da sua própria imaginação do espectador. Os medos e aflições, bem como uma agradável sensação de superação de limites (adrenalina) e de suspensão podem proporcionar uma experiência física, quando se percebe a presença e produção de sensações visitadas com o olhar.

O espetáculo Nau de Ícaros contou a viagem de uma tripulação que navega em busca de um tesouro, formada por marujos e piratas, que em mais um dia de suas viagens se apresentarão em trapézios, cordas, números de malabarismo, fogo e acrobacias. Esse tesouro foi realmente encontrado: ele é a própria criação e história da Companhia Cênica Nau de Ícaros, um tesouro que passou por diversos caminhos, nos quais o lugar que o ator-performer atua e desenha na cena é um espaço não só físico, como também um espaço virtual ou da imaginação. Nas cenas do espetáculo havia uma sobreposição dos elementos aéreos do circo, que criavam uma nova dimensão e uma profundidade da cena ampliada pela utilização do espaço aéreo. Diferente dos espetáculos de circo tradicional, no qual as cenas são fragmentadas em números que acontecem um de cada vez, o espetáculo Nau de Ícaros utilizava os aparelhos de circo não só como equipamento técnico, mas também como cenografia, na qual diferentes alturas e níveis espaciais podiam ser explorados numa mesma cena, criando um desenho de espaço múltiplo e dinâmico ao mesmo tempo.

Figura 17 - Cena do espetáculo Nau de Ícaros

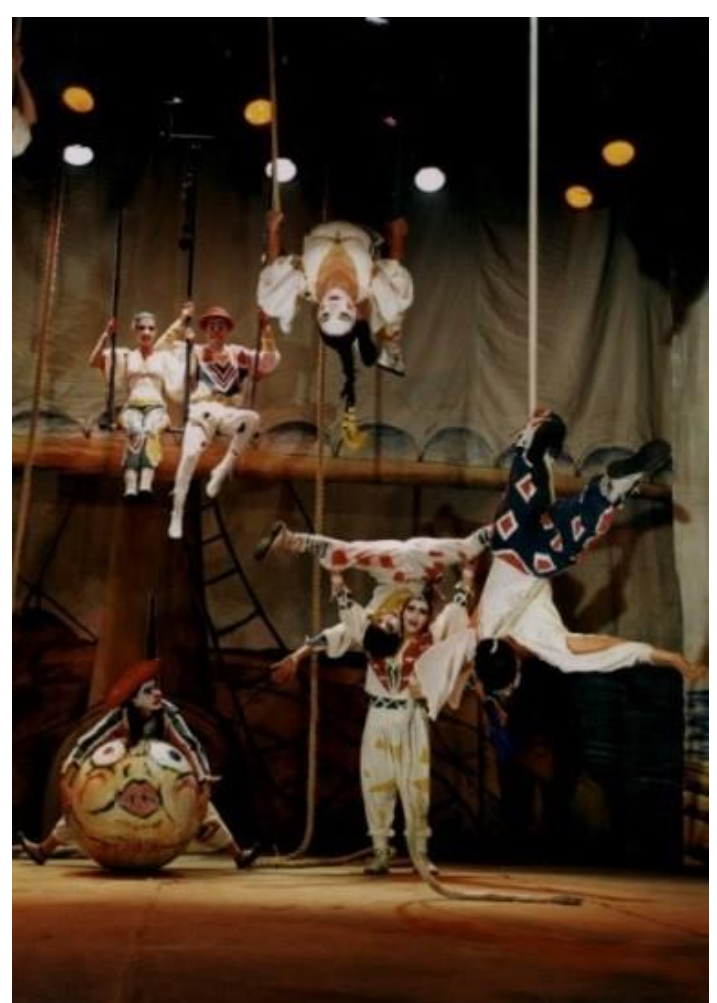

Fonte: Companhia Cênica Nau de Ícaros. Fotógrafo: Rafael Assef. 
Marco Vettore, fundador e diretor da Companhia Cênica Nau de Ícaros, assim relatou os primeiros passos da Companhia:

A gente apareceu em 1992 no Circo Escola Picadeiro, os integrantes todos se encontraram lá [...] era um contato diário, chegar às nove horas da manhã no circo e sair às dez da noite; lá no Circo Escola Picadeiro as pessoas começaram a ter uma motivação diferente do que só aprender. [...] É a trajetória do ensinamento da técnica circense. [...] Aí a gente formou o primeiro espetáculo, que chamava Nau de Ícaros. Era um lance que a gente tinha na cabeça que a história do circense tinha a ver com a história dos navegadores, muito pela ilustração criativa de um dos componentes do grupo. Aí a gente contou a história de um grupo de marujos durante um dia. Com a única mensagem que o importante era navegar e não encontrar um tesouro. [...] a pesquisa iniciou aí. [...]. (Depoimento de Marco Vettore COSTA, 1999, v. 2, p. 583-585).

Desde o início dos trabalhos da Companhia, havia uma ideia ligada ao conceito de suspensão, não só pelo fato de se trabalhar com estruturas aéreas, mas também como um estado poético de suspensão ${ }^{46}$, algo concreto, ligado ao jogo dos integrantes, mas ampliado pelo risco que o circo proporciona.

Ao sair do Circo-Escola Picadeiro, sentiu a necessidade de ter um espaço físico. Um dos fatores que torna importante esse momento foi a consciência de que a proposta da Companhia de juntar muitas disciplinas (o circo, o teatro, a dança e a cultura popular) era não só uma questão técnica, mas também artística, e exigia uma maturidade da investigação de cada um dos indivíduos.

Em uma conversa/entrevista que realizei com Marco Vettore, diretor e um dos fundadores da Companhia, ele me disse que sabia que era um longo trabalho e achava que isso estaria resolvido em seis anos no máximo - e entre risos e suspensões, lá se vão vinte e cinco anos de pesquisas.

O espaço físico era muito importante para o treinamento técnico e artístico e, mais do que tudo, tinha que ser um espaço para a própria formação da Companhia. Assim, um pensamento de se ter um espaço vazio que fosse preenchido surgiu, não só numa exploração de técnicas de circo, mas de movimento e poesia. A particularidade é que um espaço vazio para se trabalhar com as artes do circo tem que ser um espaço enorme.

\footnotetext{
46 "Estado poético de suspensão" é uma condição cênica ou uma forma como um ator-acrobata está em determinado momento na cena. É um conceito desenvolvido pela companhia em praticamente todos os espetáculos, está relacionado à suspensão onírica e a uma materialidade subjetiva, que é a própria suspensão dos corpos e da cena. Em entrevista do diretor da companhia Marco Vettore, em 30.08.2016, por diversas vezes conversamos sobre esse "estado".
} 
Nas nossas viagens com essa Nau, sempre lidamos com esse espaço que o circo necessita, brincando e comparando com a dimensão dos elefantes dos grandes circos do começo do século XX. De fato, sempre tivemos elefantes invisíveis que não aparecem, mas que necessitam de um espaço da cena em que caibam, espaço que tenha o tamanho de um elefante, bem como as materialidades da cena, que possuem o peso e a dificuldade de deslocamento de um enorme elefante. A Companhia sempre teve como particularidade romper com muitas características do circo, mas nunca conseguiu dispensar a necessidade das grandes dimensões que o circo demanda.

O primeiro galpão da Companhia se localizava na Vila Pompeia, em São Paulo, na Rua Barão do Bananal, cujo espaço era dividido com o artista plástico "Boi" ${ }^{47}$. Sem coincidências, não havia nada mais adequado para uma companhia que experimentava novas possibilidades espaciais na cena do que estar ao lado de um artista que trabalhava com artes visuais. Era uma troca mútua, na qual a companhia influenciava o artista e ele influenciava a companhia. Foi naquele espaço, relativamente pequeno, se comparado a uma lona com um picadeiro de treze metros de circunferência elaborada por Astley no século XIX, que eles plantaram a semente de como seria um espaço ideal para a Companhia trabalhar.

Esse primeiro galpão já era um espaço multidisciplinar, com um outro olhar para o circo e para as artes, e o próprio espaço exigia uma pesquisa de materiais e pontos de fixação para aéreos, diferente do que eles tinham vivenciado na lona do circo-escola. Naquela época não existia um fornecedor ou uma loja em que eles pudessem comprar os tipos de materiais que fugiam do que eles encontravam no circo tradicional, culminando em uma pesquisa técnica e adaptações exigidas pelo próprio espaço físico.

Como espaço de formação, a Companhia iniciou a escola com um movimento de troca de conhecimento e utilização daquele espaço. O primeiro convidado para ministrar um curso de acrobacia de solo foi Guga Arruda Carvalho, que formou uma turma, em que a companhia iria treinar junto com outros alunos interessados. Assim começou uma lógica de um espaço de intercâmbio de materialidades e um modelo de escola onde a companhia poderia usufruir da formação e compartilhar esse conhecimento.

Em 1994, a companhia realiza o espetáculo Sob o céu, em diversas unidades do Sesc São Paulo e em outros espaços da cidade e no interior do Estado. Foi um espetáculo criado

\footnotetext{
${ }^{47}$ José Carlos Cezar Ferreira (Marília, SP, 1944). Pintor, desenhista e, escultor, conhecido como "Boi". (Disponível em: <http://enciclopedia.itaucultural.org.br/pessoa8569/boi〉. Acesso em: 04 nov. 2016).
} 
para atender a solicitações de eventos, no qual esboços de elementos que fariam parte de toda uma história da Companhia já começavam a ser traçados.

Em junho de 1995, a Companhia estreia no Sesc Ipiranga uma montagem conjunta com a Companhia Parlapatões, Patifes e Paspalhões ${ }^{48}$, o espetáculo de rua Zerói, cujo autor e diretor geral era Hugo Possolo, que recebeu o Prêmio de Estímulo 1994 da Secretaria de Estado da Cultura. O nome do espetáculo, que é a junção de Zé ninguém com Herói, contava a história de Zerói, um ex-padre escolhido para resgatar a morte, sequestrada em um mundo onde a eternidade se tornou o maior dos tormentos, que resolve rezar e recupera a fé perdida. Ensaiado no Espaço Mazzaropi e realizado na Praça da Independência, em frente do Museu do Ipiranga, o espetáculo teve a oportunidade de estrear esse importante espaço público da cidade. A Praça da Independência recebe até hoje muitos grupos de todo o mundo que possuem características semelhantes às da Companhia, que é habitar, além dos teatros e circos, os espaços públicos das cidades.

Em entrevistas para os jornais Folha de S.Paulo e O Estado de S.Paulo, os realizadores do espetáculo falam de uma união do teatro de rua com o circo, em uma “apropriação anticonvencional do espaço urbano". Definiam Zerói como um "espetáculo evento", pois apresentava um cenário composto de três traves ${ }^{49}$ de oito metros de altura, uma ponte levadiça, um trapézio de voos e uma lona circular no chão de vinte e quatro metros de diâmetro. Diziam ser um grande circo que flutuava na frente das pessoas. O espetáculo prescindia do rótulo de "interativo", pois não forçava a participação do público, pois a interferência no espaço se tornava possível pelo contato natural com o público, e eram os elementos circenses que possibilitavam essa atitude.

Ainda em 1995, a Companhia participa da ópera Os pescadores de pérolas, no Teatro Municipal de São Paulo, com direção de Naum Alves de Souza. ${ }^{50}$

O espetáculo O pallácio não acorda estreou em maio 1997, com roteiro de Naum Alves de Souza e direção de Leopoldo Pacheco. Ganhou nove prêmios, sendo cinco prêmios Mambembe (ator coadjuvante, direção, texto, melhor espetáculo e categoria especial técnicas circenses para o teatro), dois prêmios Coca-Cola (figurino, iluminação) e dois rêmios

\footnotetext{
${ }^{48}$ Grupo fundado por Hugo Possolo e Alexandre Roit, em 1991.

${ }^{49}$ No circo utiliza-se a palavra trave para definir uma estrutura de apoio para acrobacias aéreas, que tem um formato de um gol ou trave de futebol.

${ }^{50}$ Naum Alves de Souza (Pirajuí, SP, 01.06.1942 - São Paulo, 09.04.2016) foi diretor, cenógrafo, figurinista, artista plástico, dramaturgo e professor que teve destaque em teatro, televisão, cinema, ópera e balé.
} 
APCA (ator e cenário). De uma brincadeira da Companhia Cênica Nau de Ícaros, com a afirmação de que o espetáculo transformava o palco em um divertido picadeiro, surge o enredo do $O$ pallácio não acorda, que tratava da briga de dois reis - na realidade, dois palhaços - que disputam a mesma rainha. Seus pequenos reinos entram em luta, que só será resolvida pela geração seguinte, quando o príncipe de um dos reinos se apaixona pela princesa do outro; só que na hora do casamento, o pai da noiva cai em profundo sono, enfeitiçado por um pó mágico. E, por ironia, o único capaz de acordá-lo é o monarca inimigo. A palavra pallácio, escrita dessa forma propositalmente, sugere trocadilhos durante toda a cena; os personagens principais eram os reis palhaços no espaço físico dos pallácios, ou os reis pallácios no espaço onírico dos palhaços.

Figura 18 - Cena do espetáculo $O$ pallácio não acorda: atores

Marco Vettore, Erica Stoppel e Juliana Neves

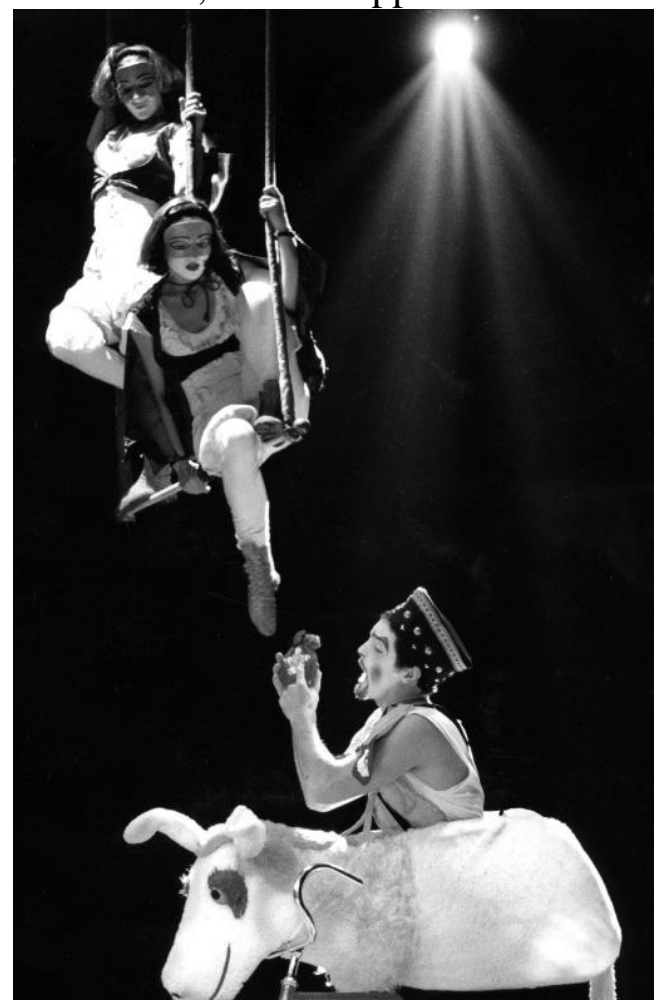

Fonte: Acervo da Companhia Cênica Nau de Ícaros. Foto: Marcelo Soubhia.

O pallácio não acorda tinha uma dramaturgia muito estabelecida e com números de circo que metaforizavam essa dramaturgia, e era uma forma de estar na cena muito nova naquele tempo e espaço, na cidade de São Paulo. 
Tanto o cenário, como o figurino, caracterizavam um castelo com seus aposentos e personagens característicos, mas não definiam uma época. O figurino e o cenário tiveram como fontes de inspiração as cidades fantásticas criadas por Philippe Druilett ${ }^{51}$, cartunista francês dos anos 70, como pano de fundo para as aventuras de seus heróis, e a experiência do cenógrafo como artista de desenho animado e os seus estudos como artista plástico, baseados na obra de Tintoretto ${ }^{52}$ e Tiziano ${ }^{53}$. O elenco utilizava um figurino básico de cor crua, que possibilitava realizar os números aéreos e acrobacias, e os outros figurinos que caracterizavam os personagens se sobrepunham, de forma que as trocas de roupa eram ágeis e práticas.

As falas eram ligadas por números acrobáticos, pirofagia $^{54}$, trapézio e corda indiana. A trama era centrada na ação do elenco, estabelecendo uma relação direta com as materialidades da cena tratadas no espaço físico do teatro e no espaço onírico do circo. A história servia de argumento para os números de circo e a narrativa, fragmentada em quadros, projetava uma harmonia entre as materialidades do teatro e circo. Atrevo dizer que havia uma inovadora e agradável conversa entre os modos de estar em cena, do teatro e do circo.

O espetáculo $O$ pallácio não acorda foi um grande momento de expansão da Companhia, pois a quantidade de apresentações realizadas pelo espetáculo possibilitou que a ela fosse efetivamente reconhecida para além da cidade de São Paulo.

Como em uma grande família circense, da equipe que acompanhou esse espetáculo surgiram parcerias muito duradouras, que contribuíram para a história da própria Companhia: Paulo Rogério Lopes, com suas palavras; Leopoldo Pacheco com seus múltiplos olhares na direção, figurino e visagismo; Adriana Vaz Ramos, resolvendo as complexidades de realizar figurinos para circenses; Wagner Freire, sempre iluminando o espaço da cena; e Raimo

${ }^{51}$ Philippe Druillet (Paris 28.06.1944). Cartunista e escritor de quadrinhos francês. (Disponível em: <http://www.druillet.com/index.php>. Acesso em: 21 out. 2016).

${ }^{52}$ Tintoretto, Jacopo Robusti (1518-1594) foi um dos pintores mais radicais do maneirismo. Por sua energia fenomenal em pintar, foi chamado Il Furioso, e sua dramática utilização da perspectiva e dos efeitos da luz fez dele um dos precursores do barroco. (Disponível em: 〈http://www.dec.ufcg.edu.br/biografias/Titoreto.html>. Acesso em: 21 out. 2016).

${ }^{53}$ Ticiano (ou Tiziano) Vecellio (c. 1490-1576), pintor italiano, foi um dos principais artistas da escola veneziana de pintura do Renascimento. A principal característica de sua obra é a sua aplicação e uso da cor, tornando-o um dos mais influentes artistas ocidentais e antecipando, em muitos aspectos, algumas características do maneirismo e do barroco. (Disponível em: <http://www.ufrgs.br/napead/repositorio/objetos/historia-arte/idmod.php?p=ticiano〉. Acesso: 21 out. 2016).

${ }^{54}$ Número circense com fogo, executado pelos chamados engolidores de fogo. 
Benedetti, com seu olhar videográfico surpreendente, todos grandes artistas e colaboradores de espetáculos posteriores que formaram o caminho dessa Nau.

Figura 19 - Apresentação em balão, São João Nepomuceno, MG

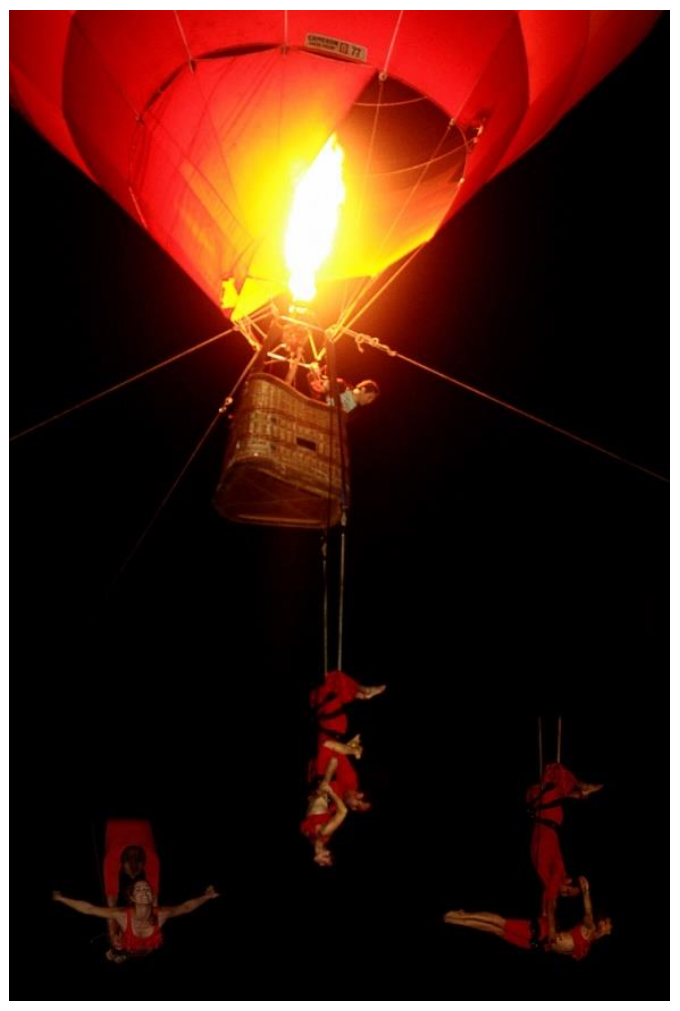

Fonte: Companhia Cênica Nau de Ícaros.

Foto: Daniel Penteado de Castro. Edição: Álvaro Barcellos.

Em 07.11.1997, a Companhia pela primeira vez faz uma “intervenção circense” em um balão de ar quente a vinte metros de altura, pilotado por Sacha Haim, campeão brasileiro de balonismo, na Praça Charles Miller, no bairro do Pacaembu. Essa primeira experimentação de uma suspensão fora da lona do circo, fora do teatro, e ouso dizer, fora da rua, estabelece literalmente o céu como espaço da cena. Foi uma ousadia resgatada de referências das artes do circo do começo do século XX, e esse modo de suspensão em balão de ar quente pode ser identificado em dois cartazes de circo: Descente d'Absalon par Miss Stena (Figura 9) e Jupiter the balloon horse, do Barnum \& Bailey Circus de 1909. Esse segundo demonstra a popularidade dos números equestres dos circos americanos, que se vangloriavam desse número com um cavalo suspenso por um balão de ar quente e cercado de fogos de artifício. 
Figura 20 - Cartaz Jupiter the balloon horse do Barnum \& Bailey Circus (1909)

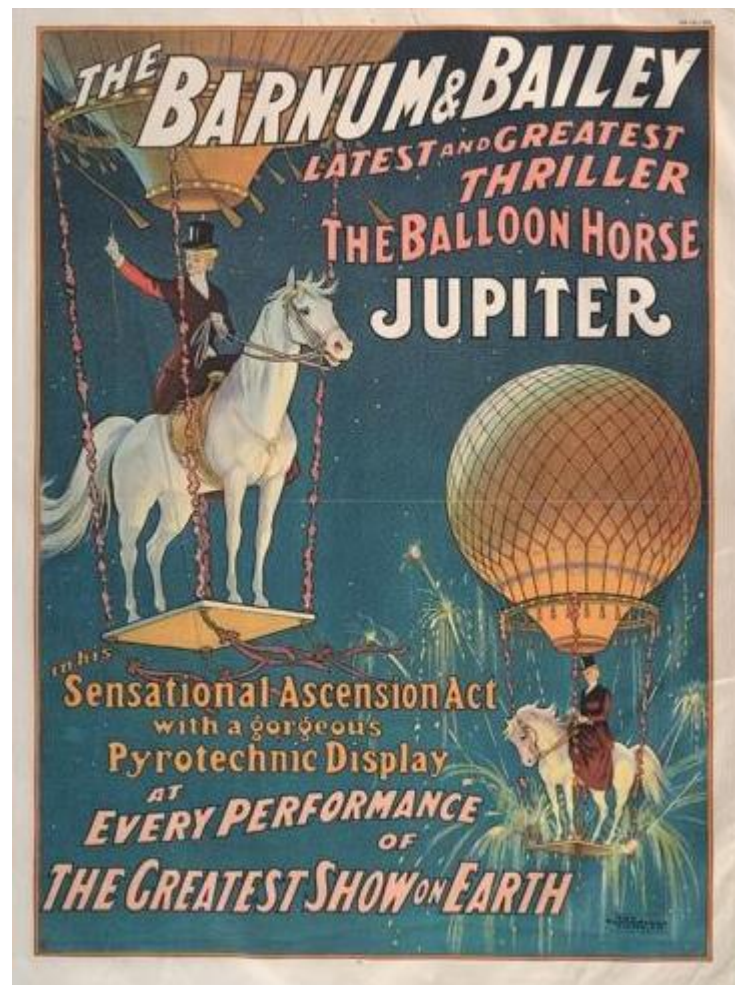

Fonte: The American Circus. ${ }^{55}$

O resgate de elementos, signos e das materialidades do circo não aparecem só nas ações da Companhia, mas é intrínseco do Projeto Nau de Ícaros. Todos os espetáculos produzidos apresentam como característica comum esse restauro do fazer artístico circense, os temas mesclam a memória das artes do circo e da forma como o circo sempre habitou e criou diversos espaços da cena.

Os primeiros voos da Companhia, que não foram poucos, representam uma série de experimentações e trocas entre muitos colaboradores. O momento de desfecho desse primeiro voo culminou com uma mudança das pessoas que faziam parte da Companhia. Da primeira formação que surgiu no Circo-Escola Picadeiro, muitos integrantes levantaram voos em outras direções, e hoje são referências nas artes do circo.

Alguns dos integrantes dessa primeira formação da Companhia foram responsáveis pela criação de importantes projetos e companhias que hoje trabalham e desenvolvem as artes

\footnotetext{
${ }^{55}$ Figura disponível em: <http://www.historyextra.com/circus>. Acesso em: 22 out. 2016.
} 
do circo no Brasil, dentre eles: Fernando Sampaio ${ }^{56}$ (Companhia La Mínima e Circo Zanni), Erica Stoppe $^{57}$ (Linhas Aéreas e Circo Zanni), Alex Marinho ${ }^{58}$ (Galpão do Circo), Patrícia Horta Lemos ${ }^{59}$ e Lincoln Rollim ${ }^{60}$ (Abbacircus), Luciana Cestari ${ }^{61}$ (Barbatuques) Mônica Alla $^{62}$ (Grupo Ares) e Paola Musatti ${ }^{63}$ (Doutores da Alegria).

\subsection{O lugar físico - Galpão Nau de Ícaros}

O galpão da Rua Barão do Bananal começou a ficar pequeno para o que a Companhia estava construindo e onde desejava chegar. Levando em consideração a origem da Companhia, embaixo da lona do Circo-Escola, eles precisavam de um espaço onde realmente coubessem "os elefantes" dessa Nau. As materialidades do circo começam a delinear para onde esses marujos iriam.

\footnotetext{
${ }^{56}$ Palhaço desde 1990, antes da formação do Grupo La Mínima, participou de diversos espetáculos com as mais diferentes companhias de São Paulo, como Nau de Ícaros, Acrobático Fratelli, Pia Fraus Teatro, Parlapatões, XPTO, Banda Palhaçal e La Mínima. Como professor de circo, trabalhou nas principais escolas de circo de São Paulo (Circo Escola Picadeiro, Acrobático Fratelli e Nau de Ícaros), além de ministrar cursos e oficinas em escolas, shopping centers, oficinas culturais, unidades do Sesc, entre outros. (Disponível em: 〈http://laminima.com.br/site/fernando-sampaio〉. Acesso em: 04 nov. 2016).

${ }^{57}$ Uma das fundadoras da Companhia Cênica Nau de Ícaros, começou no Circo Escola Picadeiro e depois, com Ziza Brisola, criou a Companhia Linhas Aéreas. Trabalhou com o Circo Mínimo e é parceira local do departamento de elenco do Cirque du Soleil. Integrou a equipe do Centro de Formação Profissional em Artes Circenses (Cefac), desde sua fundação, e também é artista criadora do Circo Zanni.

${ }^{58}$ Fundador do Galpão do Circo, é especialista de segurança no circo e foi sócio da Companhia Nau de Ícaros de 1997 a 2002.

${ }^{59}$ Atriz e Acrobata circense. Estudou dança na Unicamp fez especialização no Circus Space, em Londres. Foi fundadora da Companhia Cênica Nau de Ícaros, esteve em cartaz nos espetáculos Nau de Ícaros, O pallácio não acorda e Zerói. Em 1997, juntamente com Lincoln Rollim, criou o AbbaCircus.

${ }^{60}$ Ator, palhaço e músico, foi membro do Circo Teatro Piolin de 1978 a 1986. Participou dos espetáculos Beiço de estrada, Drop's do Halley e Até amanhã. Em São Paulo, participou de diversos trabalhos de circo, teatro e cinema, dentre eles: O baile perfumado, Processo crispim e Eu sou o servo e programas infantis de TV.

${ }^{61}$ Foi uma das fundadoras do grupo da Companhia Cênica Nau de Ícaros em 1992, atuando nos espetáculos do grupo até 1996. Foi cantora do grupo de serenatas Trovadores Urbanos, entre 2003 e 2006, com o qual fez inúmeras apresentações na cidade de São Paulo. Também atuou como musicista em espetáculos dos grupos Pé de Palavra, dirigido pela contadora de histórias Regina Machado, e Lampejo, das também contadoras Andy Rubinstein e Urga Maíra Cardoso, além de participar de gravações e shows de diversos artistas independentes.

${ }^{62}$ Bailarina aérea, acrobata, capoeirista, coreógrafa, criadora e diretora. Foi uma das fundadoras das companhias Nau de Ícaros e Linhas Aéreas, trabalhou com o Teatro do Ornitorrinco, Teatro da Vertigem e Acrobático Fratelli e colaborou com o grupo Paraladosanjos. Em 2010 coordenou o treinamento de técnicas aéreas com os atores do Teatro da Vertigem no espetáculo Kastelo. Em Londres, fundou The Capoeira Dance Company e Palmares. Em Amsterdam, atou na Kris Niklison Theatre Company e dirigiu, concebeu e atuou em Cirque de 1'Eté. Desde 2007 é diretora artística do Grupo ARES.

${ }^{63}$ Atriz graduada pela Escola de Arte Dramática da USP. Estudou e trabalhou, entre outros, com Tiche Vianna, Neide Veneziano, Francisco Medeiros, Renata Mello e Marçal Aquino. Integrou diversos grupos paulistanos consagrados. Foi uma das fundadoras das companhias Nau de Ícaros e Eugênioslávia e do teatro Armazém do Teatro. Participa do jogo de improvisação de palhaços Jogando no Quintal. Está nos Doutores da Alegria desde 1997. Disponível em: 〈https://www.doutoresdaalegria.org.br/conheca/a-equipe/>. Acesso em: 04 nov. 2016.
} 
O novo espaço estava localizado no coração da Vila Madalena, em São Paulo, na Rua Girassol, um bairro frequentado por muitos artistas na época. Era um espaço destinado à produção de proporções e estruturas ousadas. O maior desafio era organizar esse espaço para que funcionasse por conta própria, num movimento de criação que alimentasse artisticamente a Companhia.

Figura 21 - Reportagem sobre o Galpão Nau de Ícaros

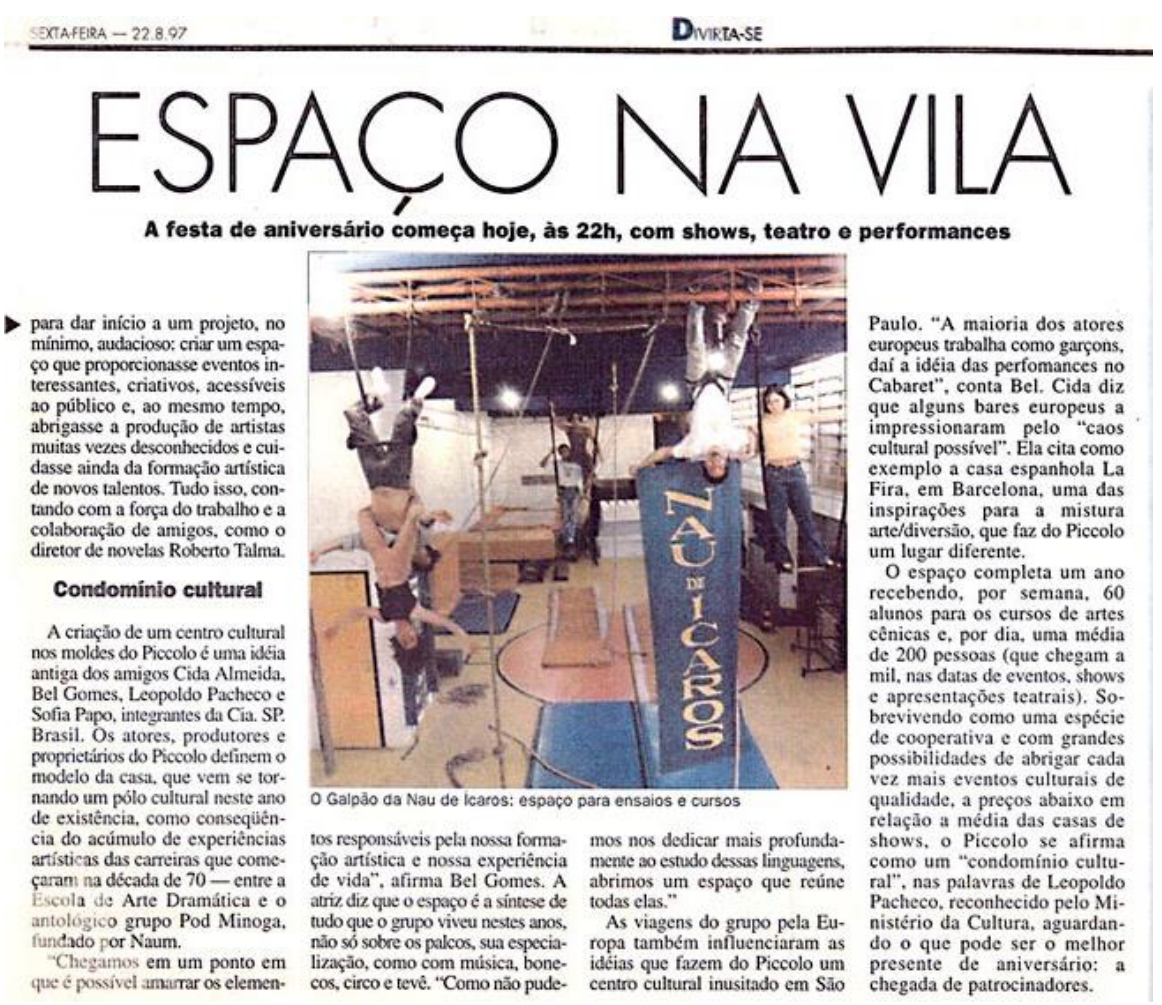

Fonte: Companhia Cênica Nau de Ícaros (Jornal da Tarde de 28.08.1997).

Primeiramente foram abertos cursos nas áreas que interessavam à Companhia, numa manutenção da pesquisa. Além do circo, cursos de dança contemporânea e danças brasileiras. Começou um movimento muito grande de pesquisa das manifestações da cultura brasileira, principalmente pernambucana, muito pela proximidade do artista Antônio Nóbrega, que ensaiava no Circo-Escola Picadeiro, na época que a Companhia também estava lá. Essa proximidade se deu pela particularidade de Antônio Nóbrega ser um multiartista que transita pela dança, teatro, música erudita e popular (Movimento Armorial), capoeira, circo e também um grande palhaço.

O Movimento Armorial surgiu em outubro de 1970 no Recife, encabeçado pelo dramaturgo e escritor Ariano Suassuna, e tinha o intuito de realizar uma arte brasileira erudita 
a partir das raízes populares de nossa cultura. Antônio Nóbrega fez parte do Quinteto Armorial $^{64}$, também fundado por Suassuna, considerado um dos mais importantes grupos a criar uma música de câmara erudita brasileira de raízes populares (COIMBRA et al., 2007).

Havia um pensamento em relação ao Movimento Armorial, que contava com guerreiros da erudição (da academia) e com guerreiros populares (da festa), que lhe parecia muito interessante, conta Marco Vettore ${ }^{65}$. O intuito era um encontro no meio desses dois mundos, erudito e popular, que aconteceria através da diversão. O Galpão Nau de Ícaros, como escola e espaço de artes, foi moldado nesse pensamento inspirado pelo Movimento Armorial, e numa grande aventura, muitos artistas e mestres pernambucanos começaram a frequentar o espaço, como o caso dos integrantes do grupo Mestre Ambrósio, que se aproximaram, constituindo um núcleo de estudos de maracatu nação, ou maracatu de baque bolado. E foi na aproximação com o Bloco Baque Bolado que resultou um espetáculo, e dessa aproximação com as pernambucalidades ${ }^{66}$, um caminho para a pesquisa da Companhia começou a se desenhar.

Era uma época em que a própria cidade de São Paulo estava recebendo muitos artistas de outros lugares do País, um momento de abertura que convergiu com o início dos trabalhos no espaço físico da Rua Girassol. O Galpão ${ }^{67}$ foi de fato o grande "porto" em que a Nau ${ }^{68}$ atracou, pois estabeleceu muitas relações e realizou um dialogo profundo com os artistas que passavam por ali, trocas que reverberam até hoje nas criações da Companhia.

Havia de fato formação de um público que frequentava o espaço, uma efervescência cultural, na qual a Companhia, junto com os artistas e os alunos, conquistou um lugar de conhecimento e encantamento. O público começou a entender o que era o trabalho da Companhia, o que era o circo junto com o teatro, o que era fazer uma dramaturgia que misturava elementos desses dois mundos com música brasileira, dança e artes visuais.

E, no mesmo período, muitos outros espaços e grupos estavam acontecendo na cidade. Havia o Brincante, um espaço criado por Antônio Nóbrega e Rosane Almeida, que se localizava muito perto, na Rua Purpurina, e tinha o mesmo público o acompanhando. Grupos

\footnotetext{
${ }^{64}$ Os integrantes do Quinteto eram Antônio Nóbrega, Antônio José Madureira, Edison Eulálio Cabral, Egildo Vieira do Nascimento e Fernando Torres Barbosa. Era composto tanto por rabeca, pífano, violão, zabumba e viola caipira, quanto por violino, viola e flauta transversal.

${ }^{65}$ Entrevista realizada em 30.08.2016.

${ }^{66}$ Refere-se a Pernambuco, que vem da cultura realizada em Pernambuco.

${ }^{67}$ O Galpão Nau de Ícaros, muitas vezes era chamado simplesmente de Galpão.

${ }^{68}$ A Companhia Cênica Nau de Ícaros muitas vezes era chamada simplesmente de Nau.
} 
como Barbatuques estavam se formando nessa época e muitos integrantes frequentaram o espaço do Galpão da Nau de Ícaros.

Outro foco muito importante foi o trabalho com as crianças, em decorrência dos espetáculos Nau de Ícaros e $O$ pallácio não acorda terem tido muito significado no universo infantil. Foi criado um curso para crianças, nomeado como Cooperação Criativa, pois fazia muito sentido desenvolver uma proposta pedagógica que transitava pelas diversas artes que o próprio espaço propunha. Também havia a preocupação de estabelecer uma conversa entre os espetáculos que desenvolviam uma dimensão múltipla das artes do circo, levando em consideração essa característica como a grande potência. A preocupação era como a Companhia, aquele agrupamento de pessoas, conseguiria lidar com os elementos diversos que as artes do circo apresentavam como opções. E o caminho naquele momento era construir um curso para crianças que fosse uma experiência total, que conversasse de fato com os espetáculos, e que pudesse sociabilizar crianças de temperamentos muito distintos.

O Galpão Nau de Ícaros era um lugar muito frequentado e disso surgiu um sentimento de obrigatoriedade criativa, relacionado à produção artística que tinha que ser gerada naquele espaço. Era um espaço muito fértil e foi um momento de muitas trocas, no qual muitos artistas se experimentaram, e a referência que a Companhia se tornou e é hoje para as pessoas de São Paulo deve muito aos momentos vividos naquele espaço.

O evento Calamenguê, nome emprestado de um tipo de tambor, surgiu dessa necessidade de trocas e produção artística; era um encontro que acontecia todos os domingos, no qual a Nau de Ícaros começou a estabelecer um “namoro" com a cultura popular.

A artista e educadora Letícia Doretto narra o momento em que ela entrou para a Companhia, nesse período:

[...] Ouvi dizer que tinha um grupo que tinha espaço para isso aos domingos, que eram encontros temáticos e chamavam Calamenguês, que rolava danças populares. [...] Teve um dia que todo mundo iria se encontrar lá e a Nau de Ícaros iria olhar pessoas para formar um novo espetáculo chamado Quase Uma [...] Eu me aproximei e nesse dia eu tive um "encontro criativo" entre eu e a Érica, onde estavam todos tocando e a gente dançou pra caramba [...] E dali eu não saí mais. ${ }^{69}$

\footnotetext{
${ }^{69}$ Entrevista de Leticia Doretto, em 19 de julho de 2016.
} 
E, nesses encontros, relações muito fortes de amizade e criatividade foram estabelecidas entre artistas que tinham um olhar mais "erudito e pensante" sobre a cultura popular, e que se aproximava de um olhar mais "erudito e pensante" que a Nau de Ícaros tinha das artes do circo.

Pensando numa produção ligada à noite paulistana que envolvesse a atmosfera das festas populares, surgiram as Ultreyas, que representavam o momento de celebrar e firmar essas trocas que aconteciam naquele espaço físico de efervescência artística. Emprestado do mesmo termo espanhol, Ultreya, que significa "ir mais além", era uma festa definida como uma provocação criativa. Havia uma obrigação imposta pelos próprios componentes do grupo de apresentar, a cada nova edição, uma proposta artística diferente, resultante de toda a pesquisa e desenvolvimento das formas de conciliar as artes diversas sob a ótica do novo circo.

A primeira vez que eu pisei no Galpão da Nau de Ícaros foi em uma Ultreya, em dezembro de 2001. Foi um instante de absoluto encantamento, que dura até hoje. Foi inesquecível estar naquele espaço, que me proporcionou um sentimento de coerência, em relação ao percurso artístico que eu havia trilhado até aquele momento. Em um mesmo espaço havia todo o tipo de pessoas, elas encenavam, dançavam e faziam circo com a naturalidade e organicidade de uma festa popular. Naquele momento tive a dimensão do lugar aberto que o circo é na sua essência, cuja porosidade possibilita que outras artes sejam absorvidas e transformadas.

Figura 22 - Espetáculo-festa

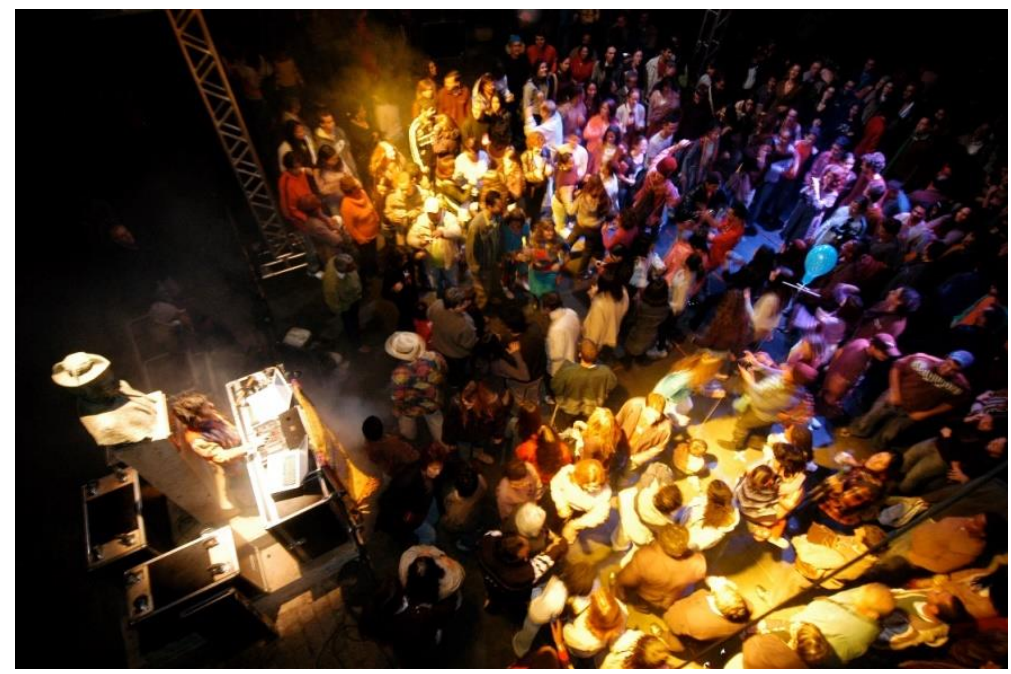

Fonte: Companhia Cênica Nau de Ícaros. Foto: Marco Vettore. 
Com tudo que uma festa compreendia, repleta de música, bar e a presença de um público bem específico que frequentava a Vila Madalena no começo dos anos 2000, a Companhia a utilizava como provocação para os experimentos, bem como trocas com os artistas convidados. O espaço do Galpão era transformado em um teatro, onde números e cenas eram apresentados pela Companhia e por convidados em um primeiro momento da festa, como uma espécie de cabaré. Num segundo momento, a festa invadia a cena, ou a cena invadia a festa, e todos os espaços do Galpão eram abertos ao público dançante e inspirado por tudo que tinha acontecido na primeira parte. Intervenções cênicas, musicais e visuais faziam com que a festa aproximasse o público dos artistas, criando um espaço da cena comum ao espaço dos observadores, que se tornavam atores daquele espetáculo-festa. Era uma forma de manter acesa a produtividade e reciclagem das performances do grupo. Era um espaço de se experimentar além da dança, do circo e do teatro, da música e do vídeo. A Companhia influenciou e foi muito influenciada por todos os parceiros que surgiram nessas festas.

Figura 23 - Espetáculo Quase uma...

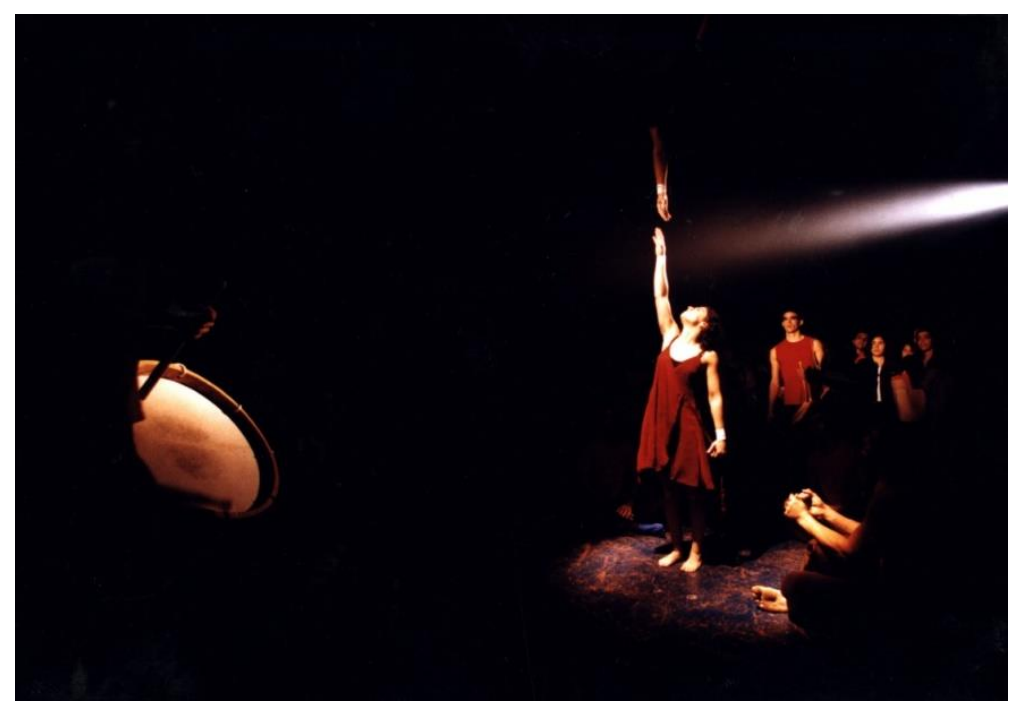

Fonte - Companhia Cênica Nau de Ícaros. Foto: Marco Vettore.

Dos encontros da Companhia com o Bloco do Baque Bolado, nas Ultreyas e no espaço fértil do Galpão, nasceu em maio de 1998 o espetáculo Quase uma..., com direção de Marco 
Vettore $^{70}$. O imediatismo e empatia desses encontros se estabeleceram pela efervescência da festa, pela necessidade de um fuzuê artístico. Eram jovens artistas que estabeleceram "uma fusão furiosa",71. Ambos os grupos estavam encantados e "futricando" pelo universo de brasilidade; enquanto o Bloco Baque Bolado andava pelos mais diversos dos ritmos brasileiros, a Companhia Cênica Nau de Ícaros era conduzida pela corrente do Novo Circo: "Um espetáculo de três sensações, uma narrativa, um comentário e uma festa.",72

O espetáculo surgiu a partir das inquietações de como ilustrar a diversidade da cultura popular brasileira e foi feito na forma espacial mais comum entre esses dois mundos, o cortejo, que nasceu de uma cena interativa que carregava elementos fundamentais das tradições de um povo: o circo, a dança e a música, mesclados ao peculiar espírito de festa dos brasileiros.

No circo o cortejo é um espetáculo em andamento livre, acompanhado pelos espectadores. Nas origens do circo, os cortejos aconteciam no dia da estreia, em todos os outros dias subsequentes e tinha a característica marcante de movimentar o cotidiano da cidade em que o circo havia estacionado. Formava-se uma cena em que a população, principalmente as crianças, seguia os artistas do circo pelas ruas da cidade, na qual anunciavam o que haveria na função da noite.

Na cultura popular brasileira, dizem que o maior incentivo para a tradicionalização do princípio dos cortejos-baile surgiram das folias, em que negros e brancos acompanhavam com danças as procissões católicas: “O costume do cortejo mais ou menos coreográfico e cantado, em que coincidiam as tradições pagãs [...] tradições profanas cristãs [...] os cortejos reais africanos e as procissões com folias de índios, pretos e brancos.” (ANDRADE, 1982, p. 33).

Em um cortejo pelos espaços possíveis do Galpão, a percussão do Baque Bolado encontrava o circo da Nau de Ícaros e tinha como pano de fundo a exploração de sensações diversas do público. Ilustradas pela fusão de imagens do videoasta Raimo Benedetti, com evocações das festas populares, as imagens eram projetadas em um tecido semitransparente esticado, que acompanhava o movimento dos atores e músicos pelos espaços do Galpão:

\footnotetext{
${ }^{70} \mathrm{O}$ espetáculo participou do $12^{\circ}$ Festival de Inverno de São João Del Rey, $7^{\mathrm{a}}$ Mostra de Teatro do Monte Azul, $1^{\circ}$ Festival Sesc do Novo Circo, e temporada de dois meses no espaço cultural A CASA e no próprio Galpão da Companhia.

${ }^{71}$ Termo retirado do release do espetáculo, em documento cedido pela Companhia.

${ }^{72}$ Texto introdutório do argumento do espetáculo Quase uma... (Cedido pela Companhia Cênica Nau de Ícaros).
} 
Desencontro feliz, possibilidade única de voltarmos a seduzir o outro, sedução louca que se descontrola e ameaça e que inicia o julgamento. Tomase a decisão de seguir em frente, duas pessoas em via de se tornarem uma. Quase uma instante vital entre a vida e uma ou duas mortes, mortes que juntas ganham outro significado o da generosidade da sabedoria de viver com as perdas. ${ }^{73}$

O espetáculo caminhava pelos espaços, aproveitava por completo todos os vazios de encenação dos espaços, no chão e no ar. Além da utilização de recursos audiovisuais, musicais e elementos aéreos que faziam parte da narrativa, também havia pernas-de-pau que se misturavam aos percussionistas, dançarinas utilizando equipamentos de alpinismo em voos envolventes, e no trapézio se desenrolava a relação entre o homem e a mulher, com ritmos brasileiros que envolviam a plateia num jogo de sensações: "Fusão de dois, cantada e entendida com símbolos claros pelos coretos, espaços bem ocupados e com alternâncias de planos e tempos. Fim que deixa um eco."74

Em Quase uma..., se as materialidades entre os dois grupos eram diversas, em compensação o espaço físico e temporal era o mesmo, culminando numa criação que brincava com o espaço da cena, com os olhares e focos do espectador. A fusão relatada no texto do espetáculo poderia ser a fusão dos dois grupos, ou também a fusão das artes, mas aqui destaco a fusão dos elementos aéreos e o movimento. A coreografia delata o deslocamento constante, as alternâncias desenham o espaço da cena nos planos e tempos ditados pela música. E o eco? O eco é uma forma de estar em cena que repercute até hoje nos trabalhos da Companhia Cênica Nau de Ícaros: "Quase uma, ameaça de duas pessoas tornarem-se uma."75

Em 1999, a Companhia Cênica Nau de Ícaros realiza duas importantes produções no mesmo espaço da cidade, no Sesc Pompeia. O espetáculo arquitetônico $O$ casamento de Lina e o espetáculo-cortejo El gran circo carnaval. Ambos os espetáculos receberam denominações compostas, referentes à forma de utilização do espaço da cena. Enquanto o primeiro verticalizou e utilizou as possibilidades aéreas e arquitetônicas, o segundo percorreu em cortejo diferentes espaços do Sesc Pompeia, explorando todas as potencialidades e transformando lugares inusitados em espaços de cena.

\footnotetext{
${ }^{73}$ Trecho do texto do espetáculo Quase uma..., cedido pela Companhia Cênica Nau de Ícaros.

74 Ibidem.

75 Ibidem.
} 
O Casamento de Lina surgiu para homenagear Lina Bo Bardi ${ }^{76}$, a partir de um desejo da Companhia de criar uma ficção em torno da arquiteta "mãe" do Sesc Pompeia e, ao mesmo tempo, inserir a presença do "pai” do Masp, a figura de Pietro Maria Bardi. ${ }^{77}$

Figura 24 - Os atores-acrobatas Alex Marinho e Erica Rodrigues, como Pietro e Lina

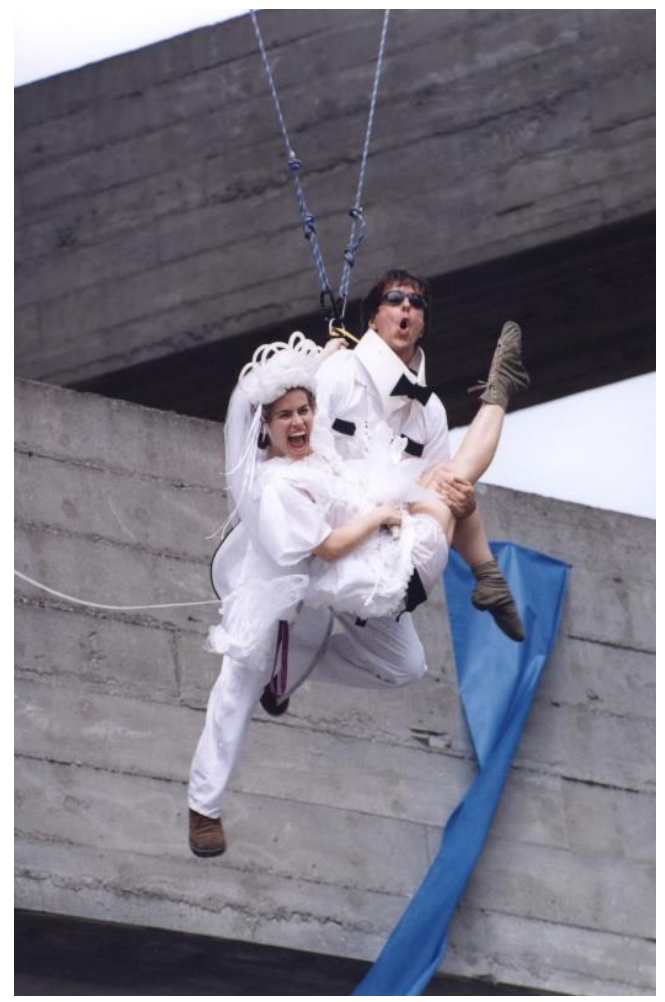

Fonte: Companhia Cênica Nau de Ícaros. Foto: Marco Vettore.

Lina Bo Bardi, que projetou o Sesc Pompeia e o Museu de Arte de São Paulo (Masp), dentre muitos outros prédios em São Paulo, foi casada com o crítico de arte Pietro Maria Bardi, que faleceu um mês antes da estreia do espetáculo, em dezembro de 1999. O casal, que chegou a São Paulo em 1946, tinha como marca de seus trabalhos a luta contra a destruição da memória arquitetônica da cidade, levando em consideração a necessidade de estar em sintonia

\footnotetext{
${ }^{76}$ Achilina Bo, mais conhecida como Lina Bo Bardi, (Roma, 05.12.1914 - São Paulo, 20.03.1992) foi uma arquiteta modernista ítalo-brasileira. Foi casada com o crítico de arte Pietro Maria Bardi e é conhecida por ter projetado o Museu de Arte de São Paulo (Masp). (Disponível em: 〈http://institutobardi.com.br/?page_id=87〉. Acesso em: 22 out. 2016).

${ }^{77}$ Pietro Maria Bardi (La Spezia, 21.02.1900 - São Paulo, 10.10.1999) foi jornalista, historiador, crítico, colecionador, expositor e negociador de obras de arte. Pietro Maria Bardi foi, junto com Assis Chateaubriand, o responsável pela criação do Museu de Arte de São Paulo (Masp), tendo sido seu diretor por 45 anos consecutivos. (Disponível em: 〈http://institutobardi.com.br/?page_id=89>. Acesso em: 22 out. 2016).
} 
com a modernidade. Nessa conjuntura, o cenário do espetáculo não poderia ser outro, pois Lina Bo Bardi sempre ambicionou casar a arquitetura com o humanismo.

Em cena vertical, duas atrizes, Erica Rodrigues e Ana Luiza Leão, vestidas de noivas, se revezavam no papel de Lina, e o ator e engenheiro circense Alex Marinho fez o papel do noivo, Pietro. Entre encontros e desencontros aéreos, dois músicos suspensos tocavam e cantavam.

Figura 25 - Passarela de concreto e ator em deslocamento suspenso

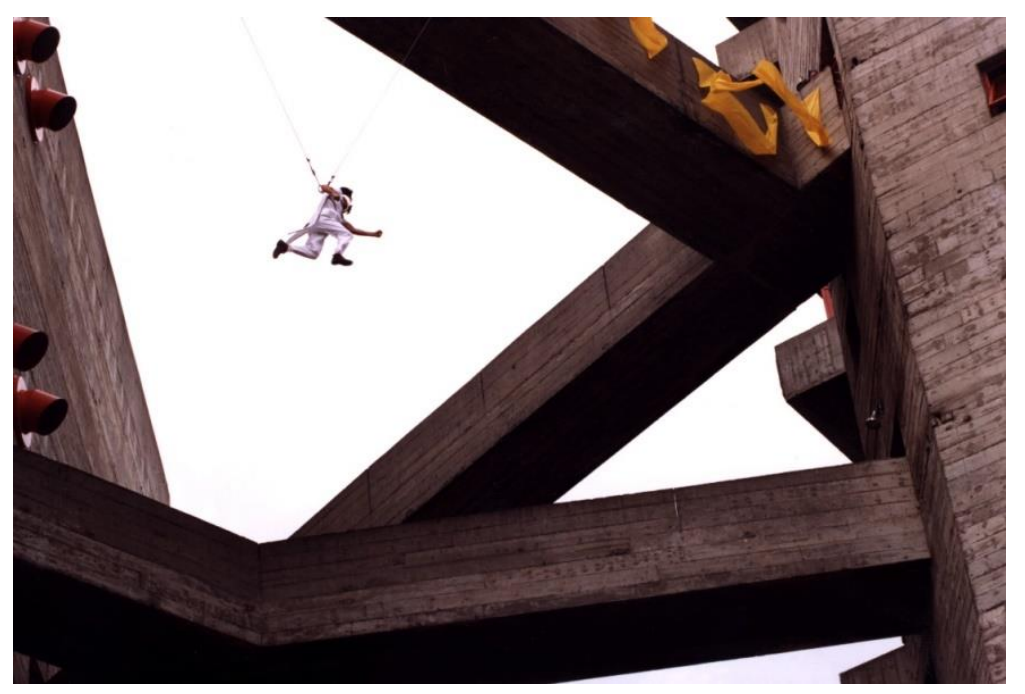

Fonte: Companhia Cênica Nau de Ícaros. Foto: Marco Vettore.

O espetáculo tinha como cenário a passarela de concreto que liga os dois edifícios do Sesc Pompeia. A boca de cena tinha $60 \mathrm{~m}$ de altura por $40 \mathrm{~m}$ de largura, era uma "moldura" que permitia ao público olhar e ampliar a visão como com uma grande angular, para contemplar os dois prédios separados pela passarela. A estrutura metálica de alumínio ${ }^{78}$, as cordas de alpinismo, os cabos de aço e todos os aparatos de suspensão já chamavam a atenção, mesmo antes dos atores estarem em cena. As materialidades do circo haviam transformado aquele espaço arquitetônico em espaço da cena, e aquela cenografia, que tinha uma função específica de criar movimento, já estava visível e atraia o olhar do público.

\footnotetext{
${ }^{78}$ Estrutura de alumínio chamada de box truss, composta de treliças de alumínio estrutural, que foram inicialmente projetadas para suporte de equipamentos de iluminação. As peças modulares permitem desenvolver diversos tipos e formatos de estruturas. Foram adaptadas para o circo por terem resistência, maleabilidade e agilidade de montagem. No final dos anos 90, algumas pessoas associavam a estética da estrutura a um tipo de modernidade na cena, pois era um material muito novo na época.
} 
Valmir Santos, em reportagem de 11.12.1999 para a Folha de S.Paulo, em uma interpretação mais arquitetônica do que circense, descreveu que o espetáculo, através da velocidade da imagem dos atores suspensos, criava o movimento da cena. Ainda comparou a um desenho animado, em razão dos vários planos utilizados, das escaladas nas paredes e das distâncias percorridas no espaço aéreo.

O espetáculo-cortejo El gran circo carnaval estreou em março de 1999, para comemorar o carnaval do Sesc Pompeia, mas se tornou, ao longo dos anos, um dos espetáculos mais versáteis da Companhia. Por ter a rua como espaço da cena, sempre há o desafio de criar um novo itinerário a cada espetáculo, a cada espaço público percorrido. É uma ocupação urbana que utiliza como cenário os espaços arquitetônicos da cidade, as ruas, os prédios e as praças. Representa uma grande celebração musical circense, com destaque para as performances aéreas de circo.

Figura 26 - Descida da Igreja Matriz de Bragança Paulista

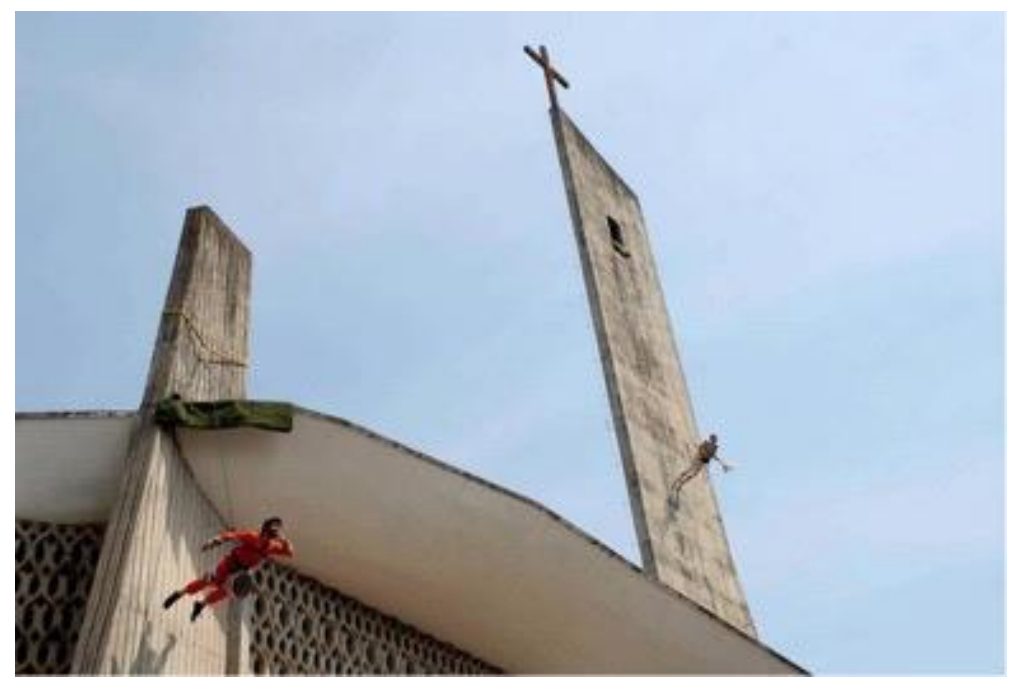

Fonte: Companhia Cênica Nau de Ícaros. Foto: Marco Vettore.

Estar contracenando com a rua sempre permitiu que o espetáculo tivesse uma grande visibilidade e envolvesse todo o público. Ao som de tambores e do ritmo do maracatu nação, juntamente com a dança e o circo, a Companhia sempre teve o intuito de ocupar e "colorir" os diversos espaços urbanos, permitindo ao espectador imprimir um outro olhar para esses locais. As intervenções de circo, como descidas de prédios, esquetes, coreografias, rappel e percussão, desenham os espaços e o roteiro da apresentação varia conforme o local. É uma 
proposta de modificação subjetiva dos locais por onde o espetáculo passa, no momento em que todos os envolvidos na ação cênica, sejam os atores como o público, passam pela experiência de olhar de outra forma aquele espaço cotidiano, onde é possível que a memória da ação cênica se torne presente toda vez que a pessoa passar por aquele lugar, mesmo depois ter vivido a experiência da cena.

A cada lugar que pude passar com esse espetáculo, tenho a impressão de que na minha memória ficou um colorido deste "carnaval", e quando passo por algum lugar onde já estive, que já foi um dia o espaço da cena para mim, meu olhar o observa com "outros olhos". O Vale do Anhangabaú, por exemplo, nunca será simplesmente mais um lugar da cidade de São Paulo depois que por lá estive suspensa, depois que desenhei o céu com meus movimentos.

Figura 27 - Espetáculo El grand circo carnaval na $1^{\text {a }}$ Virada Cultural, no Vale do Anhangabaú, São Paulo, 2005

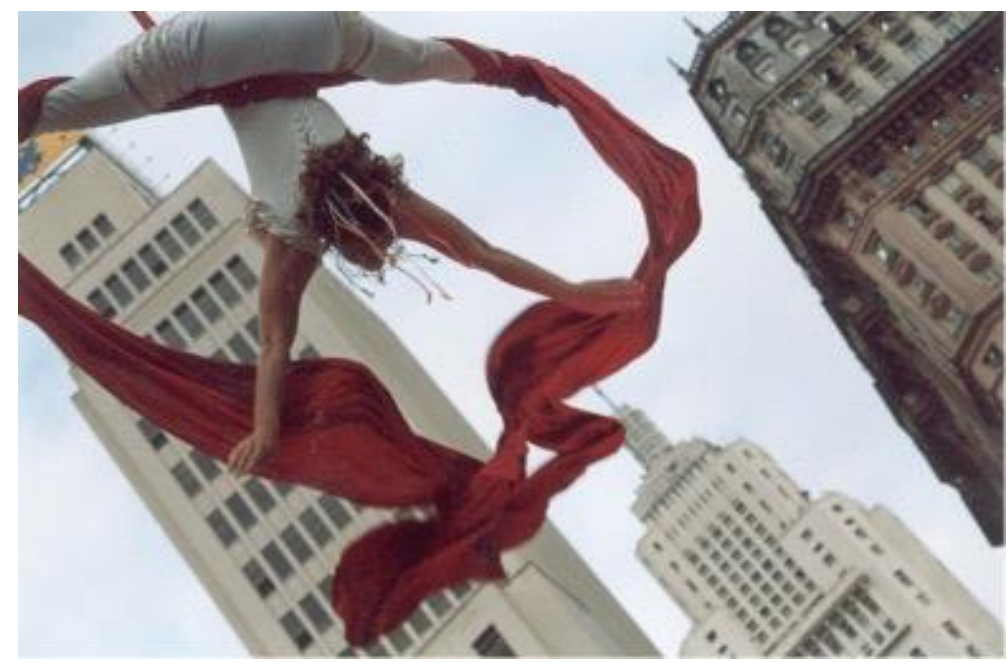

Fonte: Acervo pessoal.

Olhos para libertar, sensações para conquistar o desejo, palavras para convencer as mentes, e o exemplo para arrastar os corpos; os indivíduos. ${ }^{79}$

\footnotetext{
${ }^{79}$ Texto cedido pela Companhia Cênica Nau de Icaros.
} 
Após estrear em São Paulo, o espetáculo teve um grande histórico. Alguns lugares importantes por onde o El gran circo carnaval passou foram os $12^{\circ}$ e $14^{\circ}$ Festival de Inverno de São João del Rey (1999 e 2001); em turnê pela Europa em 2004, em cidades da Itália, Suíca, França e Bélgica; na $1^{\mathrm{a}}$ Virada Cultural Paulista (2005); no $7^{\circ}$ Festival Internacional de Teatro Callejero, em Bogotá, Colômbia; e no $37^{\circ}$ Festival Internacional de la Cultura, em Tunja, Colômbia (2009); entre outros.

Em 2000, a Companhia produz $O \operatorname{CirCo}^{80}$, espetáculo que contava a história de uma pessoa que foge com o circo em busca de seu sonho. Numa época em que não existia televisão, cinema e rádio, mostrava os bastidores de uma companhia chamada $\mathrm{O}$ Velho Circo Itinerante. Retratava a forma como os artistas viajavam, os frentistas ${ }^{81}$ que anunciavam a chegada do circo, o alvoroço da cidade ao saber, a montagem da lona, os ensaios e seus percalços, até chegar, finalmente, a noite da apresentação.

$\mathrm{Na}$ história do circo no Brasil e no surgimento dos circos-teatros, no final do século XIX e começo do século XX, podemos observar uma definição das funções das pessoas do circo ligadas ao espaço da cena. Anteriormente, as atribuições eram dadas aos integrantes das famílias circenses, nas quais todos faziam um pouco de tudo. O domínio das técnicas e o desenvolvimento das especialidades da cena foram fruto das divisões de tarefas nas equipes de trabalho nos circos-teatros:

Surgiram os cenoplastas (como eram chamados os cenógrafos circenses), roupistas (os responsáveis pela criação e execução dos figurinos), ensaiadores (quase sempre o autor do texto, ou o proprietário do circo), frentistas (divulgadores que percorriam as cidades anunciando os espetáculos antes da chegada das trupes) e iluminadores que, com poucos recursos, eram capazes de criar efeitos surpreendentes e inesquecíveis [...]. Foi no circo-teatro que a cenografia, entendendo-se o termo como o tratamento destinado ao espaço cênico, transforma-se em mais um elemento semântico do espetáculo. O público tem agora na cenografia um componente a mais que contribui para a leitura completa da encenação (ANDRADE, 2006, p. 140).

\footnotetext{
${ }^{80} \mathrm{O}$ espetáculo ficou durante dois meses em temporada no Shopping SP Market, Parque do Gugu.

${ }^{81}$ Pessoas que, antes da chegada das trupes, percorriam as cidades divulgando e anunciando os espetáculos.
} 
Figura 28 - Espetáculo $O$ CirCo: cena da velha

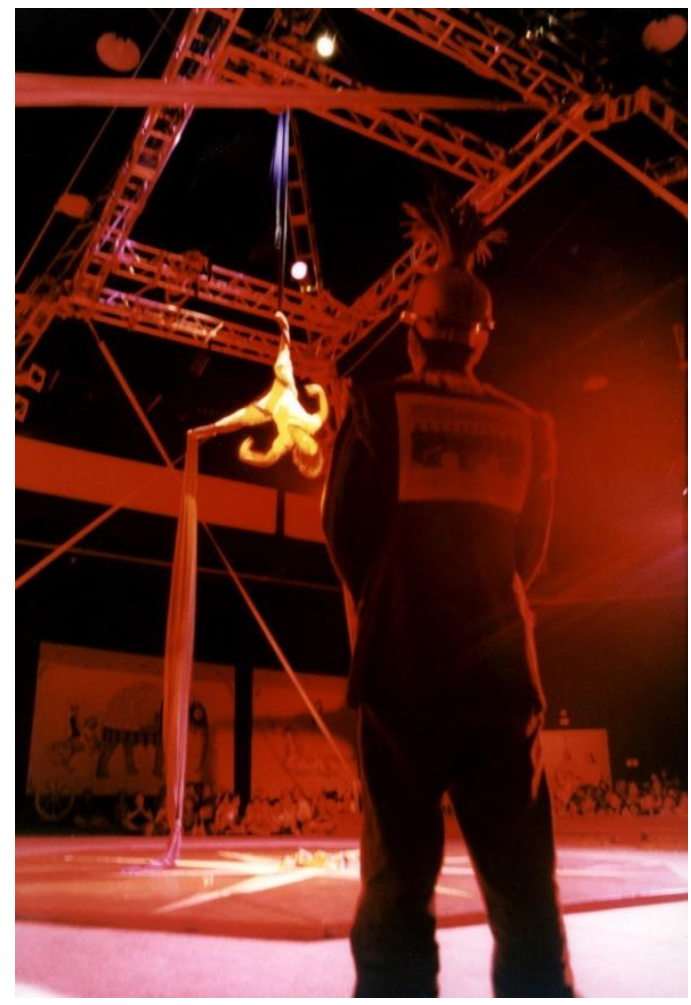

Fonte: Companhia Cênica Nau de Ícaros. Foto: Marco Vettore.

O espetáculo $O$ CirCo teve a proposta de remontar clássicos circenses, como a esquete $^{82}$ de palhaço $O$ balde e a linha; o número aéreo de doble trapézio e malabares; a clássica cena da velhinha, que interrompe a todo momento o espetáculo, jogando pipocas nos espectadores e que, de repente, se torna uma hábil aerelista é um bom exemplo de uma releitura de um clássico, principalmente pelo uso do aparelho aéreo tecido liso, que é um elemento aéreo relativamente recente dentro da história das artes do circo; o dono do circo, que a certa altura da apresentação convida o respeitável público a assistir a uma farsa na lona secundária, que tem um desfecho com a esquete da escada; a cena da boneca-bailarina, que surge de dentro de uma caixa deixada no centro do picadeiro e é suspensa, dançando, e sobe às alturas no tecido marinho.

\footnotetext{
${ }^{82}$ Derivado do termo em inglês com o mesmo significado, sketch, esquete é uma peça de curta duração, geralmente de caráter cômico, produzida para teatro, cinema, rádio ou televisão.
} 
A utilização de uma estrutura de alumínio de oito metros de altura com o formato de uma pirâmide permite que os maquinários de suspensão sejam revelados ao público, pois todas as contrarregragens se tornam aparentes, como parte constituinte da cena. Diferente dos circos tradicionais, em que toda a maquinaria era escondida, para não se revelar a "magia do circo" e das suspensões. A Companhia aponta o trabalho de pesquisa realizado para esse espetáculo como metalinguístico, pois o espetáculo fala do próprio circo, permeado de fatos históricos, no qual as tradições circenses são realçadas por novas possibilidades e tecnologias de uma arte do circo atual.

No intuito de tornar um espetáculo infantil de grande interesse aos adultos, o texto aponta um dos maiores objetivo da Companhia, que está ligado à importância e ao direito ao sonho:

Pois bem, essa é mais uma das diversas histórias de pessoas que fogem com o circo atrás de um sonho. E, para sonhar não precisa de muito, não é mesmo? Qual seria a receita, o segredo? É preciso olhos, para podermos fechá-los, um pouco de imaginação e fantasia para nos dirigir e alimentar; e por último um coração... para sentirmos. Hoje eu dividi o meu sonho com vocês, pois eu fugi com o Circo atrás dele. E você, o que está esperando? Corre atrás do seu também... ${ }^{83}$

O espetáculo AnimaAção ${ }^{84}$ surge em 2001 como a produção que consagrou a forma de habitar o espaço da cena da Companhia. As características que já vinha sendo elaboradas desde a criação da Companhia, e experimentadas principalmente no espetáculo Quase uma..., nesse espetáculo são elucidadas de forma efetiva e irão reverberar nas demais produções subsequentes.

Usando e abusando das sensações adormecidas e despertando-as na busca de um entendimento, onde o outro pode ser um aliado, e a separação de dois pode ser um encontro de quatro. Ceder não é perder. Sinto informar-lhes que temos a possibilidade da opção, generosidade é soma não é divisão. Por que não pensarmos que o desencontro de dois pode ser o encontro de quatro? ${ }^{85}$

\footnotetext{
${ }^{83}$ Trecho do texto do espetáculo cedido pela Companhia Cênica Nau de Ícaros.

${ }^{84}$ Participou da abertura do $14^{\circ}$ Festival de Inverno de São João Del Rey e teve uma temporada no espaço Galpão Nau de Ícaros.

${ }^{85}$ Trecho do argumento do espetáculo AnimaAção, cedido pela Companhia Cênica Nau de Ícaros.
} 
Figura 29 - Espaço da cena com imagem projetada à frente dos atores

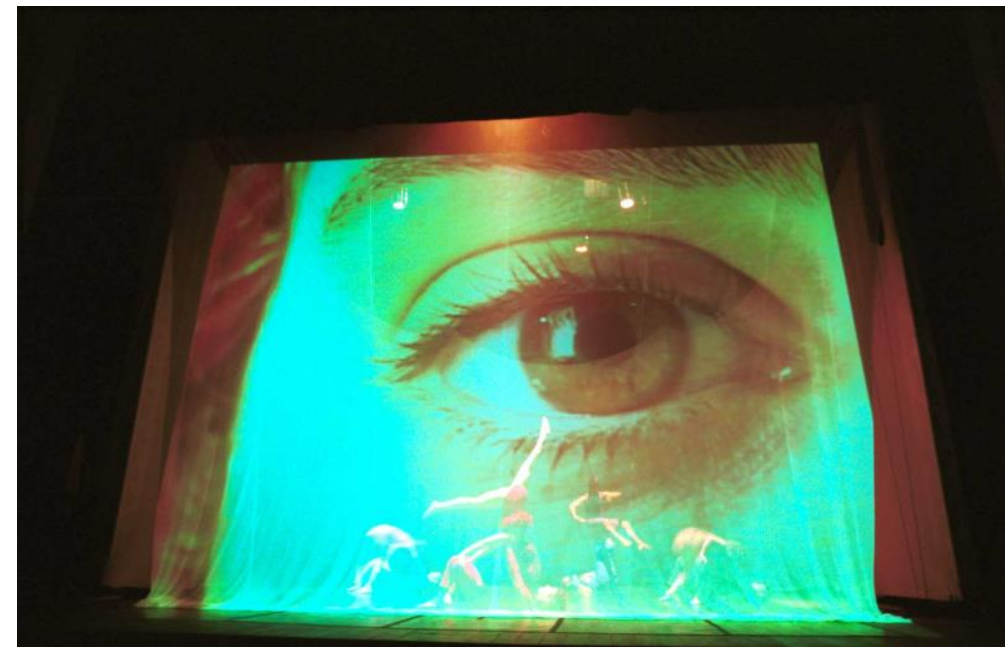

Fonte: Companhia Cênica Nau de Ícaros. Foto: Marco Vettore.

Definido pela Companhia como uma grande mistura, o espetáculo relata o universo de sensações e sentidos escondido nos encontros e desencontros de pessoas. Tinha como objetivo transmitir sensações vividas em determinados instantes da vida, sugerindo trajetórias que encenam as dificuldades e impossibilidades de se relacionar. Partindo dessas dificuldades, através do campo fértil do desafio que o circo sugere, buscavam-se outras alternativas para a comunicação, que se revelaram no atrito com o risco. Na relação espacial iniciada nesse espetáculo, a pesquisa sobre um corpo suspenso e os possíveis desequilíbrios físicos e subjetivos da cena se torna uma das principais da Companhia.

De volta à questão da porosidade do circo, como arte que está aberta a intercâmbios, as intenções quanto à encenação e a uma mistura de artes pode ser esclarecida pelo texto cedido pela Companhia, em que se delimita o que cada arte representa no contexto do espetáculo:

O Circo que sempre se dedicou às emoções, ao novo entendimento, novo como o frescor do instante, instante que se baseia no risco. Circo que reúne, em seu espaço circular, a tecnologia, muitas mídias e meios, espaço democrático e vivo do exercício do jogo, da comunicação imediata e eterna. $\mathrm{O}$ teatro que se baseia no mesmo jogo do risco da vida, do instante. Aquele que se expressa também pelo texto e se apoia sobretudo no movimento, que se mistura e se torna ritual. A Dança que flui através de um corpo que sustenta a comunicação e amplia o jogo, o risco, dando muitos gestos aos significados e cores aos corpos. A Imagem que nos permite hoje um outro jogo, o da tecnologia, não nos deixa escapar, invade e impõe ao olhar uma pausa, para olharmos a nós mesmos. E em cena mistura-se intensamente, ao vivo, com o risco e a forma dos corpos, ganhando ação e organicidade. E a música que move as sensações e faz falar aos gestos e aos significados 
ocultos do corpo, e do texto. Aquela que nos invade sem pedir licença e nos faz migrar no tempo e nas lembranças numa memória anárquica de vídeo clipe de nossas vidas. ${ }^{86}$

O projeto Galpão na rua se apresenta como uma experimentação espacial para fora do espaço da Companhia, que poderíamos também definir como uma ampliação do espaço de ensaio e da cena. Uma vez por mês, a Companhia saía às ruas para estabelecer um contato mais próximo com as pessoas, resgatando encenações tradicionais e criando provocações criativas. Tinha a ideia de resgatar a emoção do circo itinerante, atualizado pela ótica do novo circo. Esse projeto era composto por cortejos nas ruas da cidade, ensaios abertos e espetáculos em praças públicas; o espetáculo NauHumoricos foi elaborado durante o projeto.

Sempre resgatando o romantismo e a essência do circo de um outro tempo, vários quadros que falavam de namoro e da paixão entre um casal de trapezistas compunham o espetáculo infantil NauHumoricos, além de esquetes de humor entre malabaristas e o atirador de facas.

Figura 30 - Cena de Don Icário suspenso

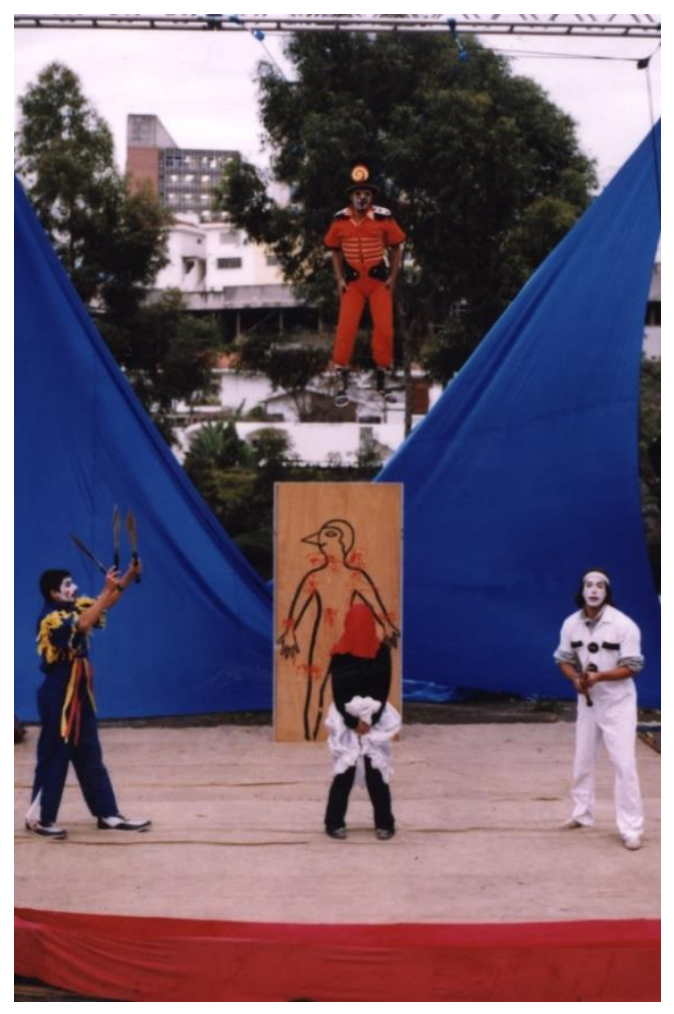

Fonte: Companhia Cênica Nau de Ícaros. Foto: Marco Vettore.

\footnotetext{
${ }^{86}$ Trecho do texto do espetáculo cedido pela Companhia Cênica Nau de Ícaros.
} 
A história do espetáculo narrava a trupe de Don Icário, que era encarregada de espalhar pelos quatro cantos a contagiante semente do "Nauhumorico", um eficaz antídoto para o mau-humor e a ranhetice que ameaça tomar conta do mundo. Don Icário conduzia seus ajudantes malucos com firmeza, na esperança de que não haver distrações no cumprimento da missão. Sem perceber, a poderosa semente já tinha começado a brotar dentro de sua própria trupe, os tornando os sujeitos mais atrapalhados, sonhadores e "enauhumoricados" que já se teve notícia.

O espetáculo tinha início com um cortejo de música de maracatu nação, forró e baião. O público era considerado mais um elemento dentro do picadeiro, pois no espaço da cena que a rua propõe todos os elementos fazem parte da encenação, todos participavam. O personagem de Don Icário, um romântico inveterado, representado pelo ator Álvaro Barcellos, merece destaque pelas suspensões feitas com equipamentos de alpinismo. Também ouso dizer que havia uma subjetiva suspensão da cena, criada pelo personagem que tinha um sotaque muito carregado e que, ao mesmo tempo em que divertia o público, remetia às figuras dos donos e apresentadores dos circos tradicionais brasileiros.

Essa sutil materialidade do circo, expressada pelo sotaque imprimido ao personagem, pode ser explicada na forma como os primeiros circos chegaram no Brasil. As companhias vindas da Europa organizavam-se como famílias e fixavam-se nas principais capitais da América Latina. O fato dos deslocamentos dos circos, apesar da grande dificuldade de transporte, acontecerem entre Buenos Aires e Brasil, trazia na figura dos apresentadores do circo os sotaque herdados da Europa e da América, e imprimiam na família circense uma memória preservada de seus antepassados.

Em 2002 a Companhia Cênica Nau de Ícaros encena o espetáculo E agora..., encomendado pelo Banco Real, que foi apresentado em diversas escolas da capital paulista.

O espetáculo $E$ agora... estabelecia alguns níveis ${ }^{87}$ de ação no espaço, o nível aéreo através dos aparelhos de circo e atores suspensos, o nível terrestre no chão, e um nível que chamaremos de palco elevado, representado pela perna-de-pau que eleva o ator, criando um espaço suspenso e terrestre ao mesmo tempo.

\footnotetext{
${ }^{87}$ Rudolf Laban (1879-1958), que desenvolveu um sistema de análise do movimento na década de 1950, utilizava a expressão "nível" espacial como uma relação de altura: alta, baixa ou média (RENGEL, 2003, p. 19).
} 
Foi o primeiro espetáculo da Companhia em que participei e, apesar de ter sido uma produção encomendada e as apresentações serem pontuais, um aspecto ligado à suspensão da cena merece destaque. A personagem que eu interpretava permanecia suspensa durante todo o espetáculo, em uma gota no tecido ${ }^{88}$. As entradas e saídas de cena aconteciam quando eu aparecia ou me escondia dentro do aparelho aéreo, que tinha um formato de casulo e representava a toca de uma coruja. Era como se fosse uma coxia aérea, e a relação com o espaço da cena era de completa suspensão, transformando o aparelho aéreo tecido em uma cenografia suspensa. A função acrobática não deixou de existir, mas também passou a ser cenográfica, ligada a uma presença e a uma finalidade no espaço da cena, além do desenho projetado pelos movimentos (ou pausas) do corpo suspenso.

Figura 31 - Cena do espetáculo E agora...: Leticia Doretto na perna-de-pau, Beatriz Evrard dentro da Gota no tecido acima à direita e Erica Rodrigues no chão

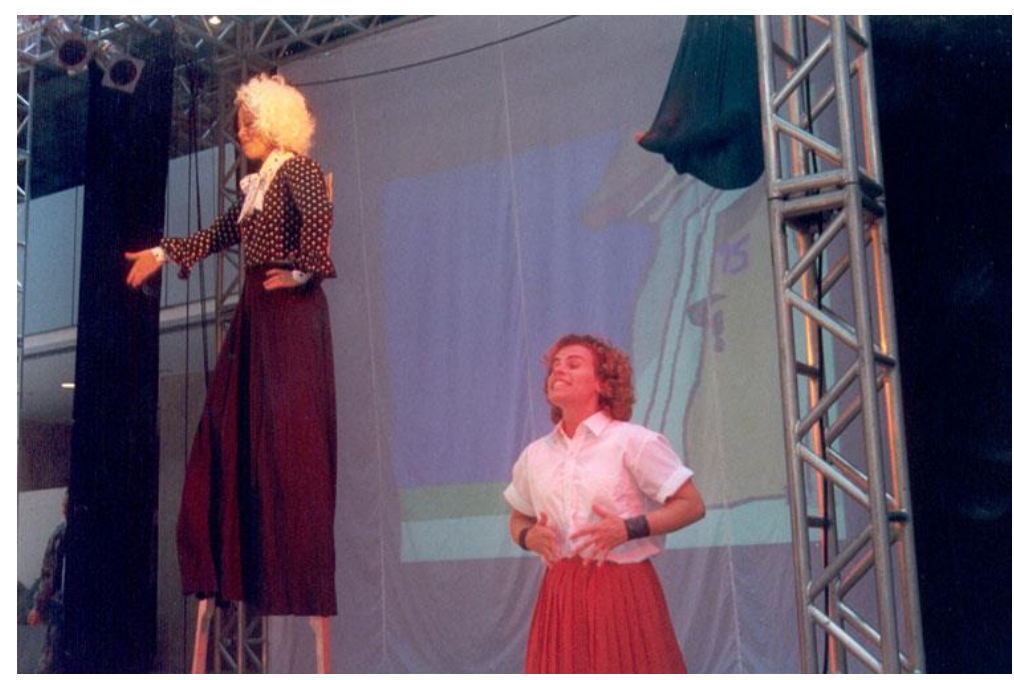

Fonte: Companhia Cênica Nau de Ícaros. Foto: Marco Vettore.

\subsection{O lugar dos sonhos - Fronteiras}

A pesquisa do espetáculo Fronteiras se misturava com as materialidades da cena impressa nesse projeto da companhia. Uma das principais características do espetáculo foi a exploração espacial, na qual todas as possibilidades estavam em jogo, a cenografia se

\footnotetext{
${ }^{88}$ Gota é uma forma de se prender o tecido liso pelas duas extremidades, formando um ponto de apoio que se
} assemelha a uma gota ou um casulo, onde é possível realizar movimentos acrobáticos horizontais. 
transformava, assim como a estória, assim como os movimentos dos atores-performers no espaço da cena.

A exploração das possibilidades da cena surgiu a partir do questionamento entre sonho e realidade. $\mathrm{O}$ espetáculo narrava a saga de Mateus ${ }^{89}$, um apresentador de circo que abandona uma apresentação e, a partir daí, tem sua vida completamente modificada. Na fusão entre sonho e realidade inicia-se um percurso pelo espaço da cena que pretende contar a estória do encontro de Mateus com Catirina ${ }^{90}$, uma bailarina do bar Fronteiras, que esperava por um bilhete de dança. A investigação dos limites, tanto físicos quanto poéticos, despertavam camadas de entendimento, criadas através de uma tensão estabelecida entre o sonho e a realidade.

O nome do espetáculo surgiu exatamente quando a pesquisa cenográfica propôs a utilização de grandes tecidos que dividiam espaços distintos, por onde o público iria transitar, com o intuito de descrever o que havia de real no sonho e o que havia de inacreditável na realidade.

Temos todos duas vidas.

A verdadeira, a que sonhamos quando criança.

E que continuamos a sonhar quando adultos,

Como um nevoeiro,

E a falsa, a que vivemos todos os dias.

A vida prática e útil

A que nos leva ao túmulo.

Temos todos duas vidas

(Vida vivida e vida sonhada; Fernando Pessoa)

As referências com o universo fantástico das festas populares eram materialidades textuais, visuais e corporais. Durante toda a pesquisa, o folguedo-cênico do cavalo marinho permeou a criação dos personagens, a elaboração dos figurinos, trouxe o ritmo marcante e a dança nos corpos dos atores-performers.

Lembro-me do dia em que me foi apresentada pela primeira vez a dança do cavalo marinho: meu corpo estranhou e o desafio era imprimir um peso e, ao mesmo tempo, acertar o ritmo para poder brincar. Os dançarinos dos folguedos populares são chamados de brincantes, pois o prazer de estar ali é fator essencial. Então, de tanto brincar, o cavalo marinho se tornou parte do meu corpo e parte do espetáculo.

\footnotetext{
${ }^{89}$ Mateus é um nome emprestado de um dos personagens principais do cavalo marinho, um folguedo cênico brasileiro, típico da Zona da Mata setentrional de Pernambuco.

90 Nome também emprestado do folguedo-cênico cavalo marinho, Catirina era esposa simultânea dos personagens que mais interagem com o publico, Mateus e Sebastião.
} 
O ritmo do cavalo marinho possibilita pausas e a dança exige agilidade e movimento durante as pausas. Na pesquisa do corpo suspenso realizada pela Companhia, as pausas rítmicas se tornaram dramáticas, os movimentos das pausas se tornaram suspensões.

Figura 32 - Cena dos Eixos, suspensões com equipamentos de alpinismo

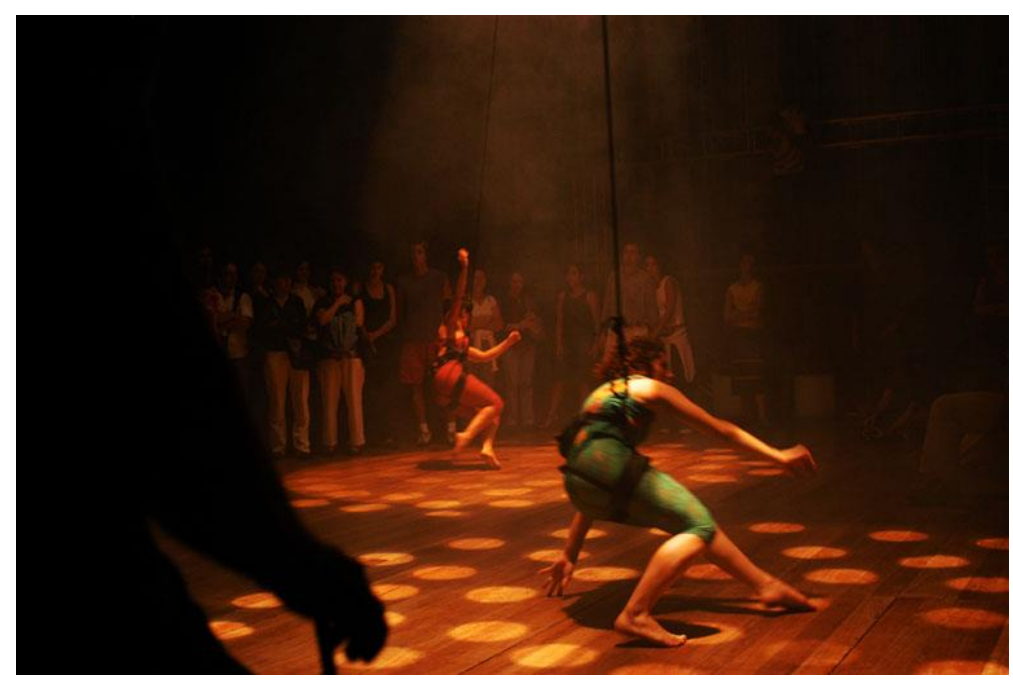

Fonte: Companhia Cênica Nau de Ícaros. Foto: Raul Camilo do Valle.

Nesse momento, a pesquisa técnica com os equipamentos de alpinismo se tornou a principal ferramenta da brincadeira. Com cordas, mosquetões e cadeirinhas ${ }^{91}$ era possível suspender os atores-performers e fazê-los transitar pelo espaço aéreo, rompendo as fronteiras dos espaços da cena divididos por tecidos.

A Companhia explicava que a cenografia seguia um conceito de "fronteira", exemplificando o limite entre sonho e realidade. O espaço da cena era dividido por tecidos em três ambientes, por onde a plateia se deslocava, conforme os tecidos se movimentavam. $\mathrm{Na}$ possibilidade de utilizar a caixa preta de um teatro, o público se posicionava sentado na condição convencional, palco-plateia, onde acontecia a apresentação de convidados da Companhia, de forma parecida com as experimentações das festas Ultreyas.

O primeiro movimento do espetáculo acontecia com a queda de metade do cenário e revelava, na lateral ao fundo do palco, um bar delimitando um espaço onde a plateia era convidada a entrar na cena, cruzando o proscênio e ocupando o palco. Esse espaço dispunha

\footnotetext{
${ }^{91}$ Nome de equipamentos de alpinismo.
} 
de um balcão com estrutura para servir de palco para a apresentação dos artistas, ao mesmo tempo que servia bebidas ao público. O espaço também era composto de um praticável, que se tornava um palco elevado de aproximadamente $4 \mathrm{~m}$ com aparelhos aéreos, tais como trapézio e lira. Também havia um tecido branco tencionado que dividia o palco ao meio, estabelecendo a fronteira que seria cruzada.

Figura 33 - Cena do trapézio duplo

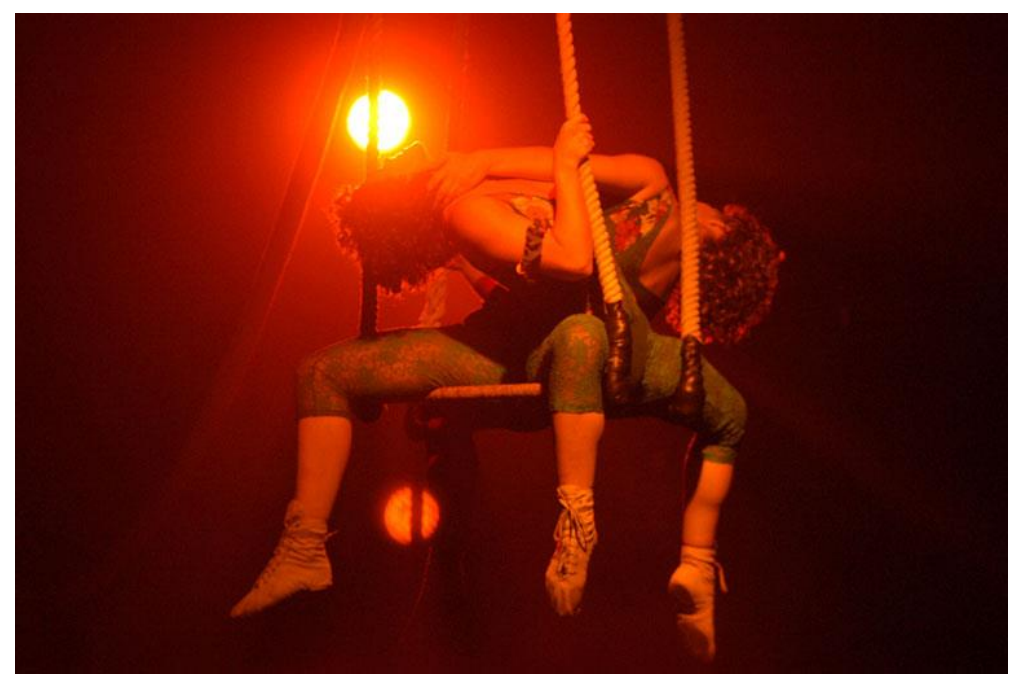

Fonte: Companhia Cênica Nau de Ícaros. Foto: Cris Von Ameln.

Após a apresentação de todos os artistas, esse tecido era rompido e revelava a outra metade do palco, fazendo deste um espaço único, com a cortina fechada. O público estava literalmente dentro da cena, dentro do palco onde normalmente só os atores-performers têm a "permissão" de estar. Esse palco ocupado é estabelecido como o espaço de "fronteiras", onde sonho e realidade se confundem.

Como integrante da Companhia Cênica Nau de Ícaros, esse foi o primeiro grande espetáculo de que participei. Era a realidade concretizando um sonho de uma artista recémformada na universidade. E, mais que isso, foi a minha primeira pesquisa e pude vivenciar profundamente a construção de uma cena que rompia os limites físicos, visuais e poéticos, meus e da cena. Atravessar a "fronteira" junto com essa "nau" não foi apenas uma ação ficcional que acontecia durante a cena, foi uma realidade vivida, fez parte da construção do meu entendimento como artista, assim como acredito que transformou a pesquisa da Companhia e a sua jornada. 
Durante o ano de 2003, o espetáculo pré-estreou como Projeto Fronteiras na Bienal de Dança do SESC Santos. No mesmo ano, com o nome Fronteiras ficou em temporada no Teatro Santa Cruz, em São Paulo.

\subsection{O lugar imaginado - Cidade dos sonhos...}

O espetáculo Cidade dos sonhos, de 2004, foi fruto de uma criação coletiva, que foi orquestrada por Leopoldo Pacheco e Marco Vettore. Foi intitulado pelo autor, Fabio Malavoglia, como uma "ópera buffa" circense, poética e gastronômica, ou um resgate em linguagem de circo do milenário mito de São Saruê (fora do Brasil conhecido como mito da Cocanha), fabulosa terra da prosperidade e da abundância, onde não há dor, suor, velhice ou morte. Ou As bacantes, de Eurípedes, transformadas em paródia no picadeiro.

Figura 34 - Estrutura cenográfica do espetáculo Cidade dos sonhos

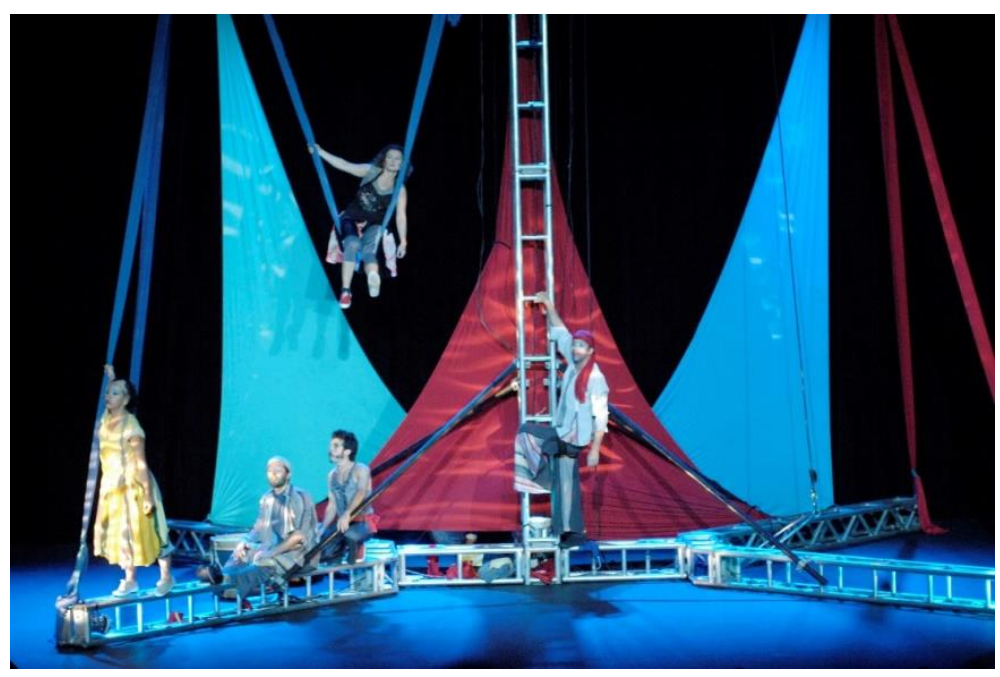

Fonte: Companhia Cênica Nau de Ícaros. Foto: Marcelo Soubhia.

Essas foram as referências que estavam presentes na criação desse espetáculo, que retomou a temática dos navegadores, tanto na construção de personagens/ marinheiros/ nômades, como na sua estrutura cenográfica, que representa um barco.

A estória retrata Panigon, o Rei de São Saruê, terra fabulosa dos rios de leite e mel, onde "quem mais dorme mais ganha" e "onde as ruas são feitas de lasanha", quando desembarca com sua trupe de ciganos-malabaristas e nômades-circenses numa "cidade feia" 
qualquer. Assim que chegam, os ciganos iniciam uma farta distribuição de guloseimas para a plateia, bem como passam a colorir e enfeitar o cenário da cidade feia. Isso conquista adeptos entre os habitantes do lugar (os espectadores), mas também leva à ira o Inspetor Furios del Thedius, defensor do statu quo, que solta fogo pelas ventas. A luta entre Panigon e sua onírica trupe circense-cigana, dada a distribuir doces, com os inimigos do sonho e dos bombons de chocolate, constitui o eixo ao redor do qual se articula a ação do espetáculo.

Figura 35 - Espetáculo Cidade dos sonhos

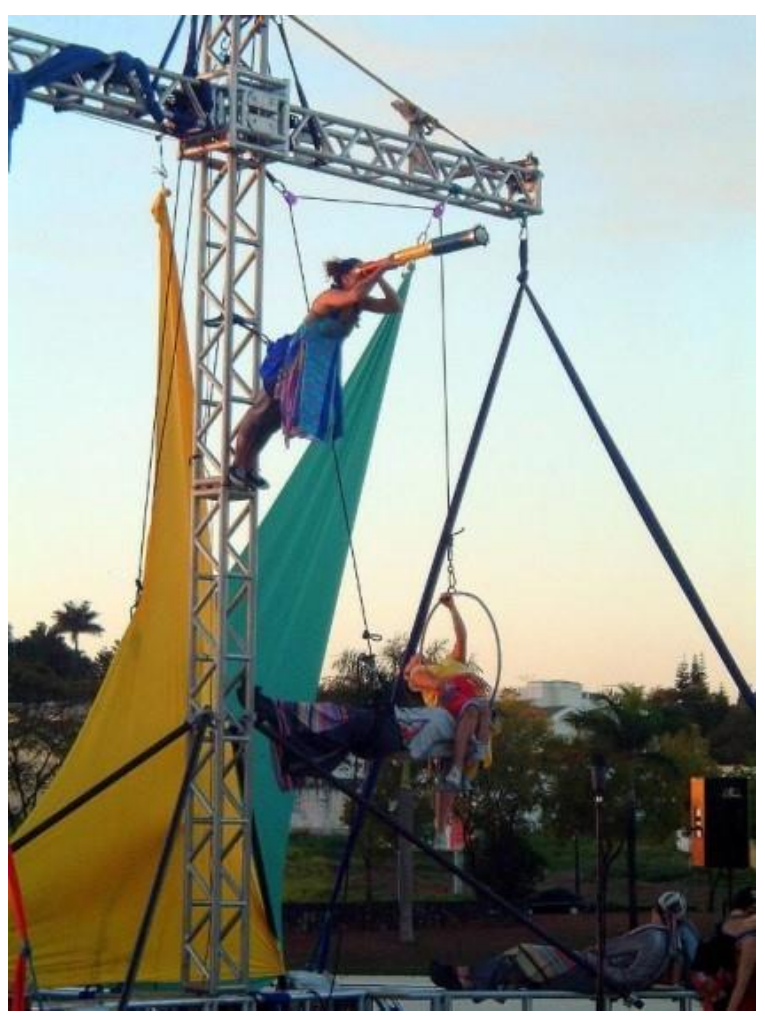

Fonte: Companhia Cênica Nau de Ícaros. Foto: Chris Von Ameln.

A cenografia acompanha o movimento da cena, se apoia em uma estrutura de boxtruss com treliça de movimento e representa o mastro de um barco que levanta suas velas para adentrar em alto mar; concomitantes números e suspensões aéreas são realizados. Possui uma versatilidade que possibilita ser montada tanto em espaços públicos (na rua, em teatros ou arenas abertas) como em prédios ou edificações e teatros; permite ao espetáculo se adaptar e também transformar os lugares em que "essa trupe" desembarca, pois a materialidade da cena se mostra de forma concreta, é uma interferência cênica (nos diversos espaços experimentados ao longo das temporadas e apresentações) que faz com que a imaginação 
invada o real e exemplifica uma característica importante apontada em estudos sobre a teatralidade, que é o trânsito constante entre fisicalidade, real e ficcional.

O espetáculo cria a possibilidade de ressignificar os espaços, delimitar o que é dentro e o que é fora da cena, ou expandir esse espaço da cena, pois em determinado momento os atores-performers dançam e se divertem no meio dos espectadores, o que torna o espetáculo um ato performativo, tanto daqueles que fazem, como daqueles que olham.

\subsection{O lugar do sagrado - De um lugar para o outro...}

$\mathrm{Na}$ continuidade das pesquisas e produções da Companhia, no intuito de lançar um olhar contemporâneo para a cultura popular brasileira e retratar o universo das tradições populares, que é parte inerente da formação do corpo brasileiro, surge o espetáculo De um lugar para o outro. A temática, ligada ao sagrado, se aproximava do arquétipo presente na figura de Exu, orixá da cultura afro-brasileira. Foi criado para ser uma jornada pelas várias facetas do orixá Exu, amplamente presente no imaginário e no cotidiano popular.

No espetáculo De um lugar para o outro, a experiência de ter José Possi Neto presente na criação permitiu à Companhia observar a presença do encenador como criador do espetáculo que, em sua atuação, diferente de um diretor, se apropriou e esteve presente em todos os aspectos do espetáculo: vídeos, figurinos e coreografia, iluminação, maquiagem, todos os detalhes passaram pelo encenador.

Estabelecendo um paralelo entre os conceitos de teatralidade e o papel do encenador, ao observar a forma como ele atuou na produção, temos uma visão integrada do espetáculo desenvolvida através de uma troca de conhecimentos entre os atores-performers e o encenador, o que possibilitou que as cenas criadas dialogassem no espaço da cena de forma fluida, entregando à plateia signos a serem decodificados, estabelecendo um ato consciente (FERNANDES, 2011, p. 17), tanto para os performers e o encenador, quanto para os espectadores.

O seu próprio título, De um lugar para o outro, já anuncia uma relação espaço, cena e tempo, e designa movimento e olhar, um modo de escritura cênica que está relacionado ao 
espaço percorrido, a estórias contadas por meio da fisicalidade e a uma jornada entre o real (as ações) e o ficcional (aspectos ligados a um arquétipo), um trânsito constante entre esse corpo e essas estórias.

Figura 36 - Espetáculo De um lugar para o outro

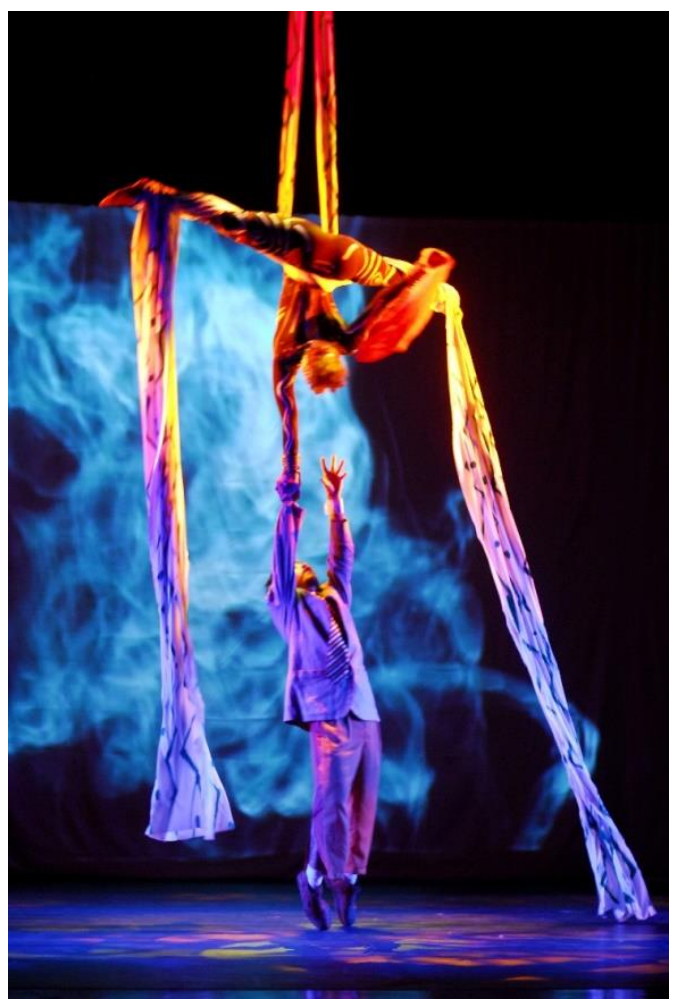

Fonte: Companhia Cênica Nau de Ícaros. Foto: Cris von Ameln.

Nesse jogo do corpo e de uma cenografia que desenha o espaço estão presentes projeções numa tela semitransparente posicionada na boca de cena, que exibe por vezes símbolos e pegadas, e também imagens do personagem principal, um homem que caminha e atravessa diversos seres e situações que demonstram as várias facetas desse orixá Exu.

O diálogo dinâmico entre o mundo real e o fantástico resulta num espetáculo imagético, de uma estética brasileira, no qual a fusão de imagens e sensações encontra na composição do espaço aéreo a possibilidade de transcender os limites da cena. 
Figura 37 - Espetáculo De um lugar para o outro: uso de cordas de alpinismo

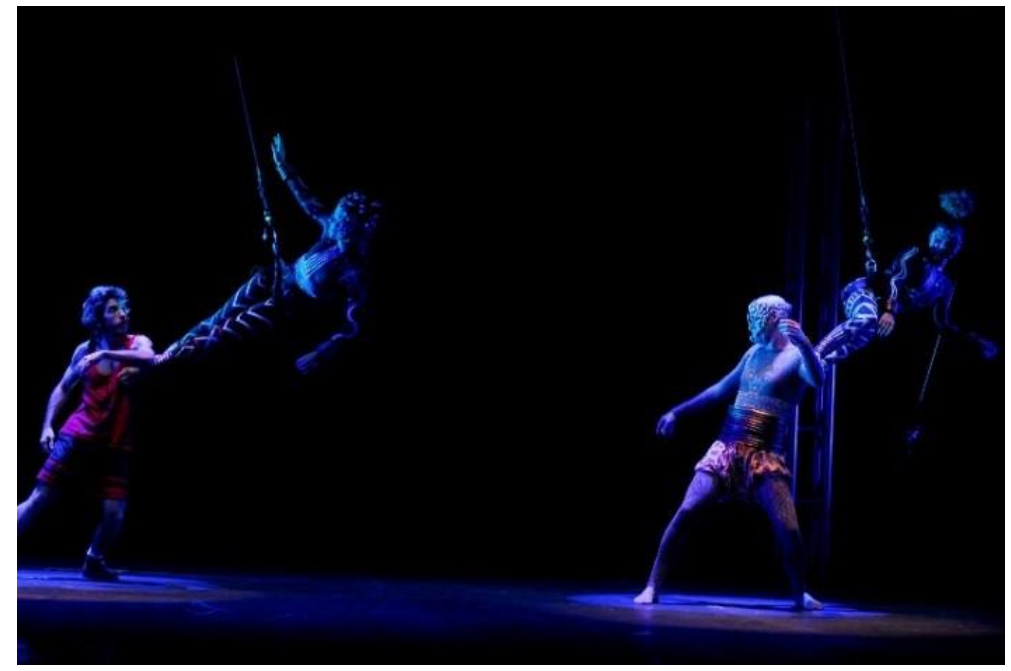

Fonte: Companhia Cênica Nau de Ícaros. Foto: Henrique Lenza.

Com a utilização de cordas de alpinismo, tecido e lira, foram encontradas diferentes qualidades de movimentação, por meio de apoios invertidos e suspensões, que alteram a dimensão do espaço, os limites do equilíbrio e do desequilíbrio, provocando a sensação do risco e a alteração do eixo e do tempo do movimento.

A presença do risco para o ator-performer, que não é só físico, mas também artístico, constitui a performatividade dessa criação. Há um jogo repleto de riscos entre o olhar do espectador e o que é registrado na cena; as descrições das várias facetas do orixá Exu, da forma real como são representadas nas manifestações religiosas em que está envolvido, são reorganizadas e é instaurado um jogo com os códigos e as capacidades do espectador. Há uma desconstrução do real, que se pode identificar e observar na descrição de Josette Féral sobre as obras performativas:

Essa desconstrução passa por um jogo com os signos que se tornam instáveis, fluidos forçando o olhar do espectador a se adaptar incessantemente, a migrar de uma referência à outra, de um sistema de representação a outro, inscrevendo sempre a cena no lúdico e tentando por aí escapar da representação mimética (FÉRAL, 2008, p. 203).

O espetáculo é composto por diversas cenas e passagens pelo palco, como se houvesse diversas performances coladas umas às outras, nas quais as descrições do orixá estão permeadas pelas ações que o representam, uma sequência de movimentos que mostram diversas realidades, que desconstroem as anteriores, a cada apresentação de uma nova realidade, novos signos, sentidos e linguagens. 
Ao final de uma das apresentações desse espetáculo, um espectador relatou para um dos integrantes da companhia que a cena que mais havia gostado tinha sido a "cena da vergonha"; e logo o ator-performer se perguntou: Mas qual é mesmo a "cena na vergonha"? Nesse momento, o olhar do espectador traduziu de forma inesperada uma das cenas, que era composta por dois atores-performers em pernas de pau, com uma indumentária representando figuras fantásticas e sagradas que, por meio de uma cenografia móvel (composta pelas próprias pernas de pau e por um bambu) possibilitavam ao personagem central do espetáculo, que estava com parte do corpo exposto, realizar suspensões e ser carregado. As figuras enormes diante do ator-performer criavam um jogo de dimensões e formas no espaço e tornavam a figura desse personagem pequena, diante desses seres fantásticos. Essa cena, que não havia sido nomeada e tinha imagens possíveis presentes, foi intitulada pela primeira vez pelo espectador de "cena da vergonha", e esse olhar que assiste e invade os significados de quem realiza a ação pode ou não modificar sentidos e leituras. Representa uma liberdade criada pela teatralidade, que possibilita sair de lugares fixos e vedados, abrindo novas possibilidades e interpretações.

Figura 38 - Espetáculo De um lugar para o outro: uso de pernas de pau

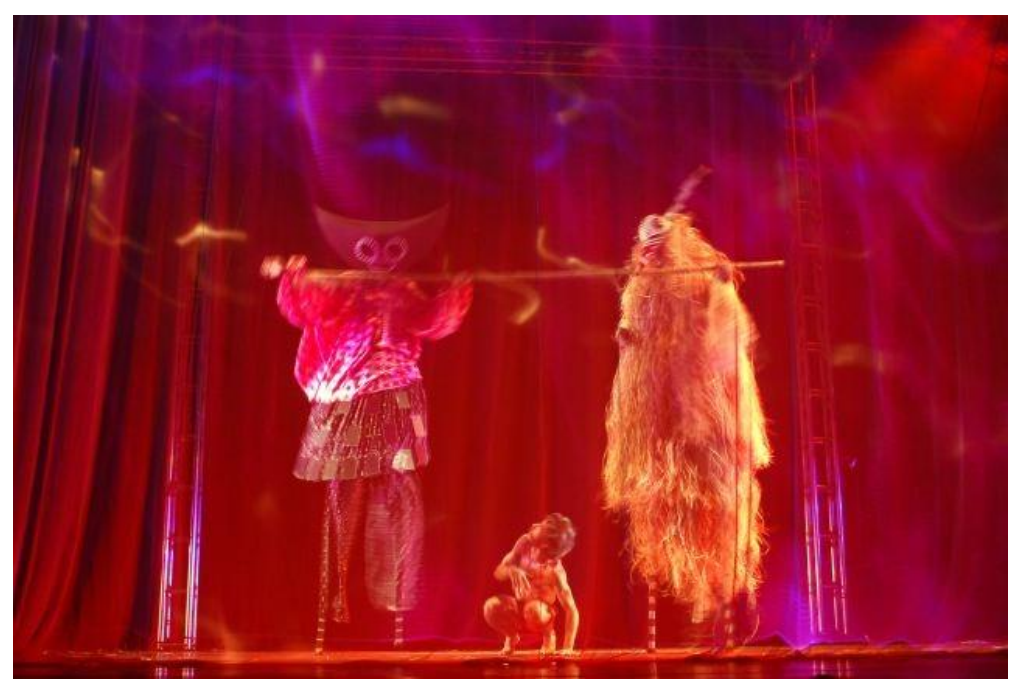

Fonte: Companhia Cênica Nau de Ícaros. Foto: Henrique Lenza.

Considerando a utilização dos elementos de circo como materialidades da cena, principalmente quando no espaço da cena os aparelhos aéreos do circo se fundem aos corpos dos atores-performers, e esses elementos se misturam e desenham o espaço, o espetáculo $D e$ um lugar para o outro pode ser visto como uma obra performativa, na perspectiva 
apresentada por Josette Féral: “As obras performativas não são verdadeiras, nem falsas. Elas simplesmente sobrevêm. [...] De um lado, seu caráter de descrição dos fatos. Por outro, as ações que o performer ali realiza." (FÉRAL, 2008, p. 203).

Figura 39 - Espetáculo De um lugar para o outro: projeção e acrobacia aérea

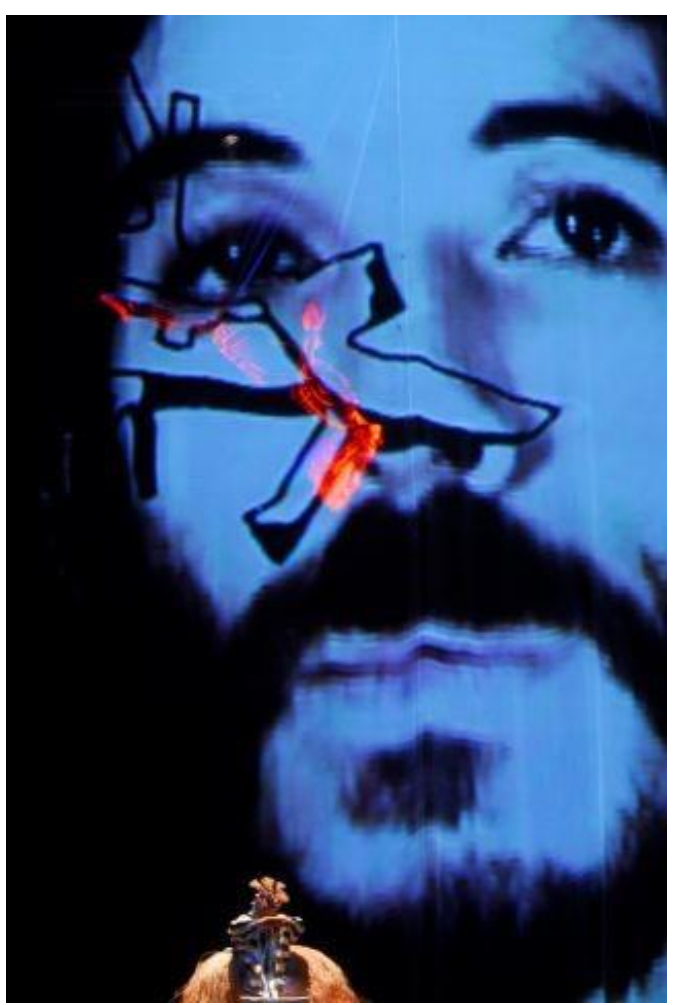

Fonte: Companhia Cênica Nau de Ícaros. Foto: Henrique Lenza.

\subsection{O lugar no mundo - Menor que o mundo...}

Menor que o mundo foi um convite do SESI-SP para comemorar os 110 anos de Carlos Drummond de Andrade. É um espetáculo livremente inspirado na obra desse poeta e a principal característica da montagem é o diálogo entre elementos simbólicos do universo drummondiano e o entrelaçamento dos elementos de circo, da música, da dança e do teatro, traço marcante e presente em todas as criações do Projeto "Nau de Ícaros". 
Figura 40 - Cena final do espetáculo Menor que o mundo

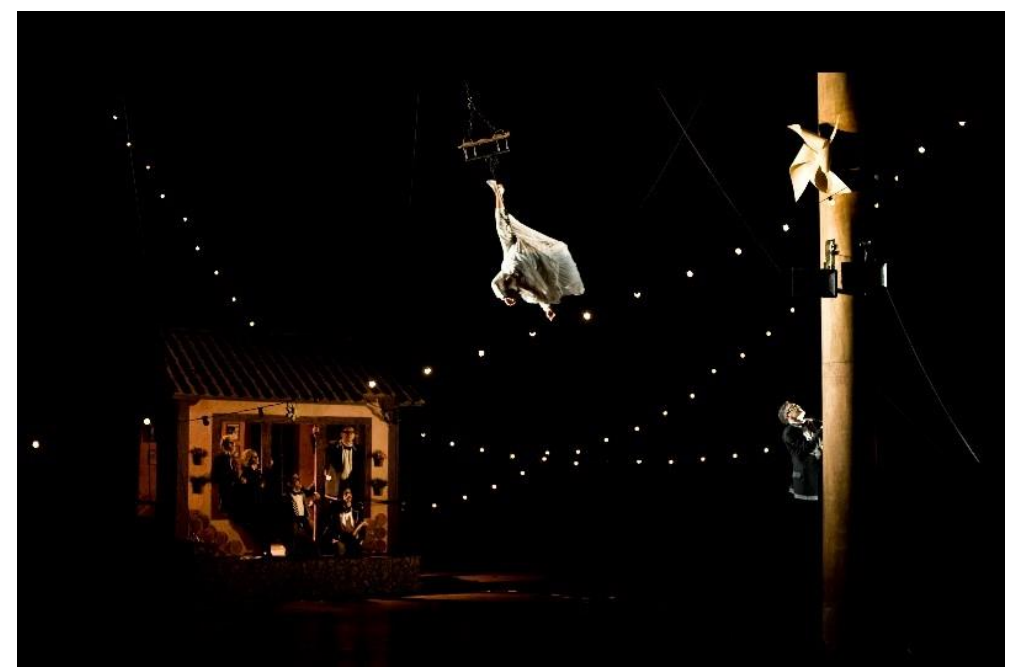

Fonte: Companhia Cênica Nau de Ícaros. Foto: Chris Von Ameln.

O público teve a oportunidade de conhecer um poema cênico de sete faces: sete personagens que carregam o engenho, a ironia e a melancolia do poeta mineiro.

Com dramaturgia e direção de Leonardo Moreira, o espetáculo tratou a obra de Drummond e refez - em movimentos, voos, palavras - os encontros e desencontros de personagens retirados da obra do poeta mineiro. Personagens frágeis, loucos, narcisistas, líricos, patéticos, em completo descompasso com o lugar, ora maiores que o mundo, ora menores que o mundo.

Em Menor que o mundo há uma quadrilha formada pelos personagens Lili, a irmã mais velha e revolucionária, que não amava ninguém; a noiva que recebe cartas de amor de J. Pinto Fernandes, que não vai entrar na história; o carteiro, um romântico herói da Paramount, que amava a noiva de outro, e que também espiava as vidas dos outros, pelas cartas que distribuía todas as manhãs; a irmã mais nova, uma beata que dança black bottom todas as noites e que se esconde atrás da igreja; o sorveteiro, que segue gauche na vida e que sabe que o amor começa tarde; aquele soldado, que vigia a cidade com pedras nos bolsos para que todos permaneçam na mesma ordem de sempre e que se diz viúvo; o outro soldado, que também zela pela ordem, mantém sob vigília o vento e o catavento da cidade e acredita que a liberdade é o que se paga pela paz.

Essa "Quadrilha" retratada no espetáculo tem uma teatralidade semelhante à do próprio poema. Em um estudo e notas apresentadas por Gilberto Mendonça Teles, numa análise de parte da obra de Carlos Drummond de Andrade, no qual aproxima o poema com a 
obra "Memórias póstumas de Brás Cubas" de Machado de Assis, é construída uma reflexão sobre a relação musical e coreográfica e, por que não dizer, uma teatralidade em que elementos expressivos e movimentos que o poema propõe são pontuados:

A sensação musical e coreográfica é produzida pela repetição encadeada da oração adjetiva restritiva que tem como verbo amar, mostrando concomitância e ao mesmo tempo certa inconstância na ação de amar. [...] O ritmo do poema é realmente expressivo [...] é fácil imaginar os movimentos e as características musicais de uma quadrilha. [...] Sendo de notar o aspecto de continuidade obtido com o diálogo crescente do final do poema, como sugerir que a situação continua se repetindo (ANDRADE, 1985, p. 165).

O processo de criação de cada um dos personagens se deu a partir de um mergulho na obra de estreia Alguma poesia, de Carlos Drummond de Andrade (2001). Cada um dos intérpretes da companhia, instigados pelo diretor, procurou encontrar imagens e cenas dentro dos poemas escritos entre 1923 e 1930. Assim, cada intérprete trouxe o seu olhar particular apreendido desses poemas, numa proposta de selecionar um personagem da obra e criar uma gênese para ele, que tivesse relação com seu corpo e sua história, resultando na criação de um corpo-poema que se relacionava com a obra de Drummond.

Podemos apontar que, ao emergirem corpos-poemas, eles deram vida a uma cenografia poética, que reflete uma teatralidade carregada de aspectos das estruturas poéticas drummondianas, onde há uma evidente relação da movimentação dos intérpretes com a cenografia. A cada etapa da criação, assim como os personagens ganhavam vida, cor, gestos e palavras, as materialidades da cena herdavam as perspectivas desses corpos-poemas.

Outra proposta do diretor aos intérpretes, que influenciou diretamente no desenho da cena, foi encontrar cinco imagens dos poemas do livro e, a partir de cada uma, criar cinco breves instantes de ação, tempo e espaço. Partituras corporais e técnicas aéreas foram utilizadas para expressar as ações das narrativas criadas e, a partir dessas imagens, se estabeleceu uma intimidade com os poemas e obra de Drummond. Essa familiaridade criada se deu em um âmbito subjetivo, quando os assuntos e temas foram apreendidos, e também num âmbito objetivo e concreto, quando houve a criação de um percurso e desenhos, nos quais uma relação espacial particular presente nos poemas de Drummond foi estabelecida e materializada.

Os intérpretes se apropriaram das imagens criadas, que influenciaram a composição das sete figuras que mais tarde seriam os sete personagens do espetáculo, através da utilização 
de exercícios de viewpoints de composição cênica e coreográfica, que também proporcionaram outros conteúdos espaciais. Ao dividir o espaço da cena em três áreas (social, íntima e do sonho), o espaço foi delimitado e vivenciado livremente, as figuras criadas pelos intérpretes "habitaram" essas áreas compondo ações e partituras de movimento e o objetivo de ocupar o espaço com as características dos personagens e dos poemas de Drummond foi alcançado.

Os aspectos relatados resultaram em um espetáculo que possui uma continuidade de ações que se repetem, com uma proposta de modificação espacial muito comum no cinema: é como se a cena fosse apresentada de diversos ângulos possíveis. Parte da cenografia é centralizada em uma casa (por meio de uma estrutura com rodas) que transita pelo espaço da cena, podendo ser olhada de diversos ângulos; cada lado dessa casa é a habitação de um dos personagens (carteiro, irmãs, soldados e sorveteiro), as paredes e objetos retratam as características de cada um, podendo ser apresentados diversos "mundos" em cada uma das paredes dessa casa.

Figura 41 - Casa da cenografia do espetáculo Menor que o mundo

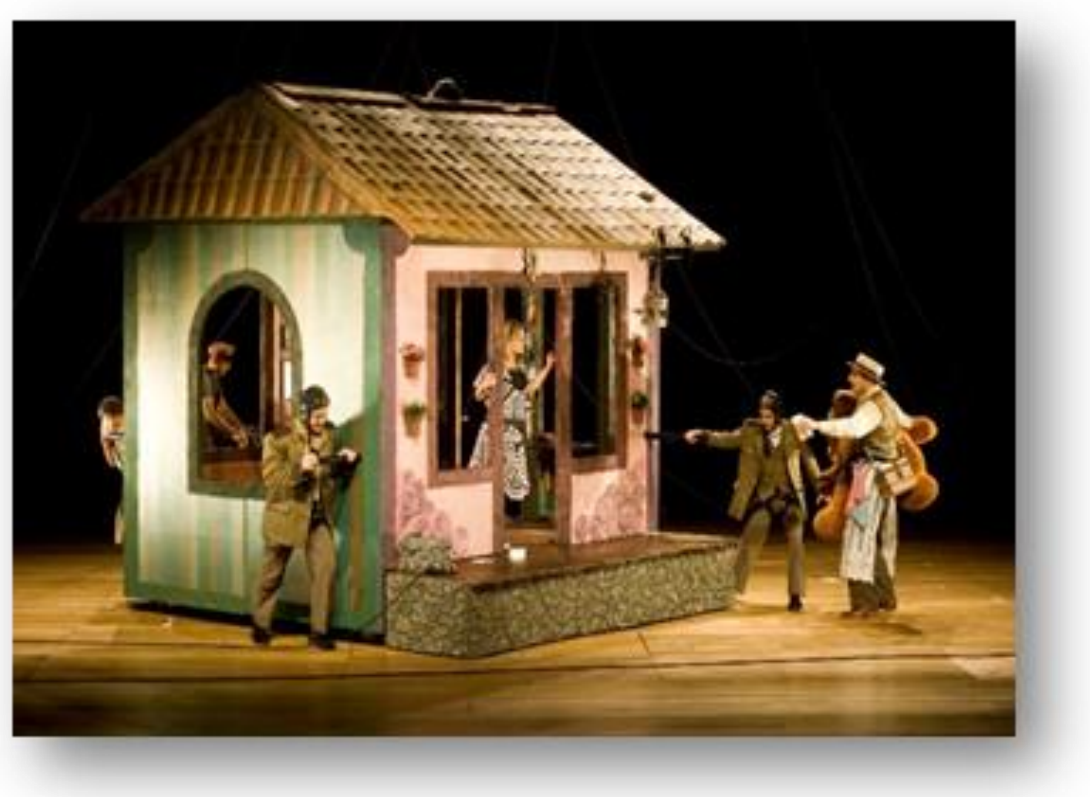

Fonte: Companhia Cênica Nau de Ícaros. Fotógrafo: Chris Von Ameln. 
As ações que voltam a acontecer em ângulos distintos podem estar relacionadas a um caráter repetitivo, que Richard Schechner aponta nas manifestações de performance (MOSTAÇO, 2009, p. 18) e se aproximam dos aspectos que identificam as obras performativas. A repetição das ações resulta numa série de identificações, em que o imaginário produz os significados, em que as condições e conexões entre o dentro e fora da cena estão ligadas à percepção de quem assiste.

Esse aspecto ligado à performatividade pode ser identificado nessas unidades que se replicam, tanto na materialidade da cena, como na temática do espetáculo (inspirado na obra e poemas de Drummond):

Não estamos mais lidando com um original e uma cópia, mas num mundo onde tudo é cópia ou, melhor dizendo, nada é original: tudo é intertexto [...] onde tudo se replica, tudo se reproduz, tudo se torna signo de signo, confundindo a origem e mesclando as derivações, a exigir novas apreensões para interfaces entre os fenômenos (MOSTAÇO, 2009, p. 33).

Outra característica marcante ligada à cenografia e aos elementos de circo utilizados são as cordas de alpinismo que, além de terem a função de equipamentos que possibilitam a suspensão dos corpos dos atores-performers, desde o primeiro momento do espetáculo aparecem como parte da dramaturgia.

Durante o processo de criação, foram imaginadas diversas cenas utilizando cordas de alpinismo; essas cordas, que são acompanhadas por um equipamento de segurança (cadeirinhas, mosquetões, fitas e freios), se tornaram parte integrante da dramaturgia, no momento em que a própria estória passou a girar em torno de uma cidade onde o vento era tão forte que as pessoas precisavam andar amarradas no chão:

Ali era uma cidade de gente minúscula, no meio do vento. Alguns, que tinham conseguido se salvar dali, mandavam cartas com a notícia de que o mundo, o grande mundo estava crescendo todos os dias. Mas aqueles poucos que ficaram não acreditavam. Eles eram do tamanho do que viam: as casas espiavam os homens que corriam atrás das mulheres. Era só o que o viam, era só o que eram. E seus olhos não perguntavam nada. A tarde talvez fosse azul se ali não houvesse tantos desejos. E se ali não houvesse tanto medo de sair voando com o vento, talvez eles não tivessem decidido se amarrar ao chão. E como ali o vento também levava embora todas as palavras, eles preferiam não falar, mas ouvir suas próprias vidas sendo narradas por outro. Vida contada no rádio. Vida vivida era mais perigosa que o vento, teriam dito se soubessem falar. $\mathrm{O}$ que eles sabiam era que ali a vida era uma ordem (SERVIÇO SOCIAL DA INDÚSTRIA, 2012, p. 77-78). 
Figura 42 - Cena do espetáculo Menor que o mundo, com todos os atores no espaço da cena

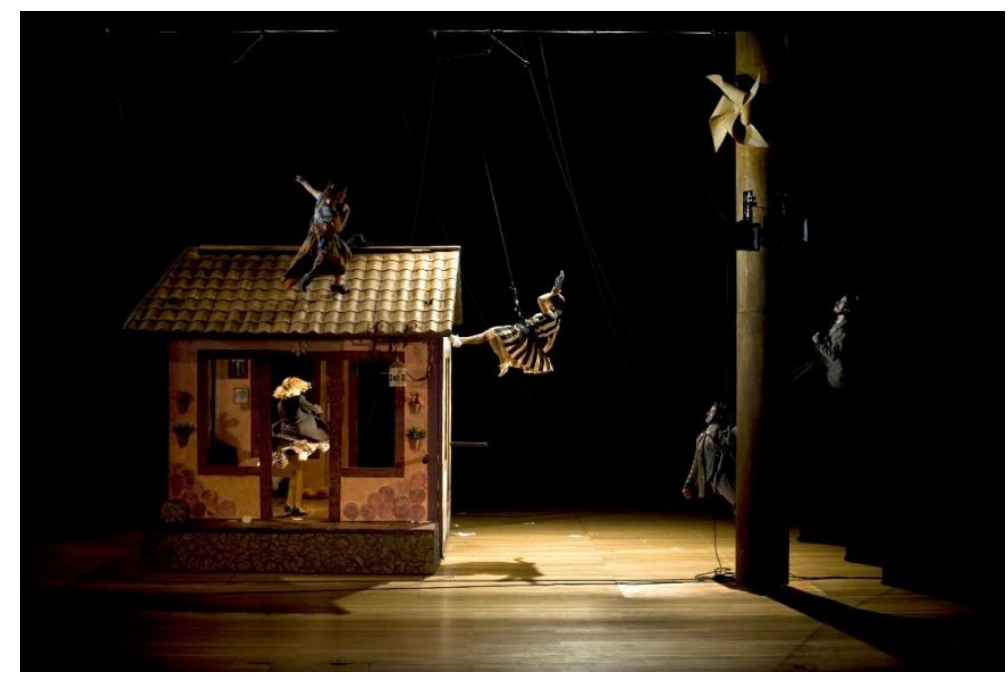

Fonte: Companhia Cênica Nau de Ícaros. Fotógrafo: Chris Von Ameln.

Os elementos cenográficos interferindo na dramaturgia e na construção dos personagens, a partir de seus corpos que também contam estórias, se aproximam do lugar do performativo, no qual o simbólico e o energético dialogam e uma movimentação na qual erros e falhas são possíveis. No espetáculo Menor que o mundo, a ação do "vento" se mostra incontrolável em termos ficcionais e reais, pois o movimento de pêndulo de cordas e aparelhos de alpinismo nem sempre percorrem a mesma trajetória de desenho de cena: é uma inconstância prevista e pretendida que transita pelos corpos dos atores-performers e chega pelo olhar à imaginação do espectador.

\subsection{O lugar do movimento...}

Com mais de vinte anos de história e uma trajetória de sonhos, conquistas e realizações, a Companhia Cênica Nau de Ícaros é reconhecida pelo seu trabalho artístico e também por projetos de expansão, que envolvem cultura e educação. Suas produções aqui relatadas se caracterizam pela intersecção de diferentes elementos, em busca de uma identidade única, sempre com total interação e diálogo com o público. Os anos de pesquisas e reflexões para criar espetáculos que propuseram um olhar contemporâneo sobre a cultura popular brasileira descreve uma paixão pelo País e pela imensidão cultural que ele 
proporciona. É o desejo de querer mostrar ao mundo as particularidades dessa trupe, valorizar as raízes, histórias, mitos e festas, para aproximar o espectador desses elementos comuns a todos.

Relatar esse modo de escritura cênica, o trabalho dessa companhia, dos atoresperformers, dos objetos e dos corpos em cena faz com que os percursos percorridos por esses espetáculos identifiquem uma relação espacial, por meio das especificidades que o circo possibilita na cena; é uma forma de habitar em movimento o espaço que está ligado diretamente ao processo de criação e aos sujeitos em processo. No centro de seu funcionamento como companhia, nas suas teatralidades, como espetáculo e como corpo que desenha no espaço, há uma noção de performatividade. Todos os elementos aqui descritos aproximam-se de um teatro performativo descrito por Josette Féral, bem como uma escrita cênica desconstruída e completamente envolta por riscos espaciais, corporais e dramáticos.

O projeto "Nau de Ícaros" desenvolve dentro de suas criações o que podemos chamar de ato performativo, no momento em que aqueles que fazem e olham estão no mesmo espaço da imaginação, desfrutando a mesma sensação de risco e uma liberdade que permite novas possibilidades e interpretações. É um espaço no qual o imaginário é desenvolvido e absorvido, caracterizado por uma cenografia que acompanha o movimento da cena, ressignificando lugares onde a imaginação invade o meio.

Podemos dizer que, como projeto ligado à fisicalidade, os limites desse corpo e desse espaço em movimento criam performatividade, formam uma relação entre sentido e materialidade, em que a presença participativa de todos os envolvidos é impulsionada pela inclusão do público. Esse dentro e fora da cena, ligado à percepção e olhar, é o que impulsiona os voos dos Ícaros em busca de novos lugares, nos mesmos lugares. 


\title{
3 O LUGAR DO AMOR - GÊNESE DO ESPETÁCULO TIRANDO OS PÉS DO CHÃO...
}

\begin{abstract}
Margarida escreve, Olga escreve, Jandira, Ana, Helena, Maísa, Antônia, Lucia e Beatriz... e tantas outras. Elas perderam seu amor, elas nunca o encontraram, talvez eles tenham outra ou talvez elas tenham outro. No "consultório sentimental" de Nelson Rodrigues tudo termina em amor e não só nele. "Tirando os pés do chão" baseia-se neste estado atordoante e entorpecente que o amor nos coloca - em suspensão, para retratar as diversas cartas presentes no livro e seus mais sentimentais temas. Um espetáculo, entremeado de textos, que traça um paralelo entre o amor hoje, e o amor de Nelson. Através das cartas são levantados os temas como: amor idealizado, o ciúme, o perdão, a traição... desenvolvidos em cenas, esquetes e coreografias. Um espetáculo de dança que fala das sensações que envolvem o amor a partir das reações físicas que este nos causa. Baseado na obra "Myrna - Não se pode amar e ser feliz ao mesmo tempo" de Nelson Rodrigues. (Sinopse do espetáculo Tirando os pés do chão - texto cedido pela Companhia Cênica Nau de Ícaros).
\end{abstract}

Este terceiro capítulo destina-se a construir uma gênese do projeto e espetáculo Tirando os pés do chão, da Companhia Cênica Nau de Ícaros. Ao relatar fatos e causas que contribuíram para a formação e concepção dessa obra, destacaremos a importância desse espetáculo na reflexão de um fazer artístico que tem os elementos aéreos do circo como matérias objetivas e subjetivas da cena.

Esses elementos que constituem o espaço onde a cena é realizada contribuem para a composição e estruturação dos lugares físicos utilizados e transformados em espaços da cena. Denominadas como materialidades da cena, tais elementos não são constituídos apenas de objetos cenográficos existentes no espaço, mas também são os elementos poéticos presentes na temática do espetáculo - o amor - que evoca a sensação de suspensão.

Observar a aproximação dos elementos cenográficos com os poéticos e os corpos em movimento no espaço da cena é o propósito desta gênese.

Tirando os pés do chão surgiu a partir da pesquisa específica da Companhia acerca do corpo em suspensão e de como o "estado" de suspensão está presente em todas as esferas relacionadas à cena. $\mathrm{O}$ próprio título do espetáculo se relaciona à ação de elevar-se fisicamente ao tirar os pés do chão, ao mesmo tempo que oferece imagens que representam a sublimação do corpo, quando o amor evoca gestos e ações, sentimentos e emoções. Da mesma forma, a relação do peso gravitacional com o sentimento amor é inspiração para 
algumas reflexões acerca da utilização dos elementos aéreos do circo como cenografia(s) no espaço da cena.

O fio condutor da pesquisa de Tirando os pés do chão foi estabelecido por meio de uma série de entrevistas, que começaram internamente entre os integrantes da Companhia, e se ampliaram aos amigos e familiares próximos, alcançando o público em geral, através das chamadas "ações performáticas", que foi a primeira etapa do projeto.

Figura 43 - Entrevista realizada entre os integrantes e amigos da Companhia

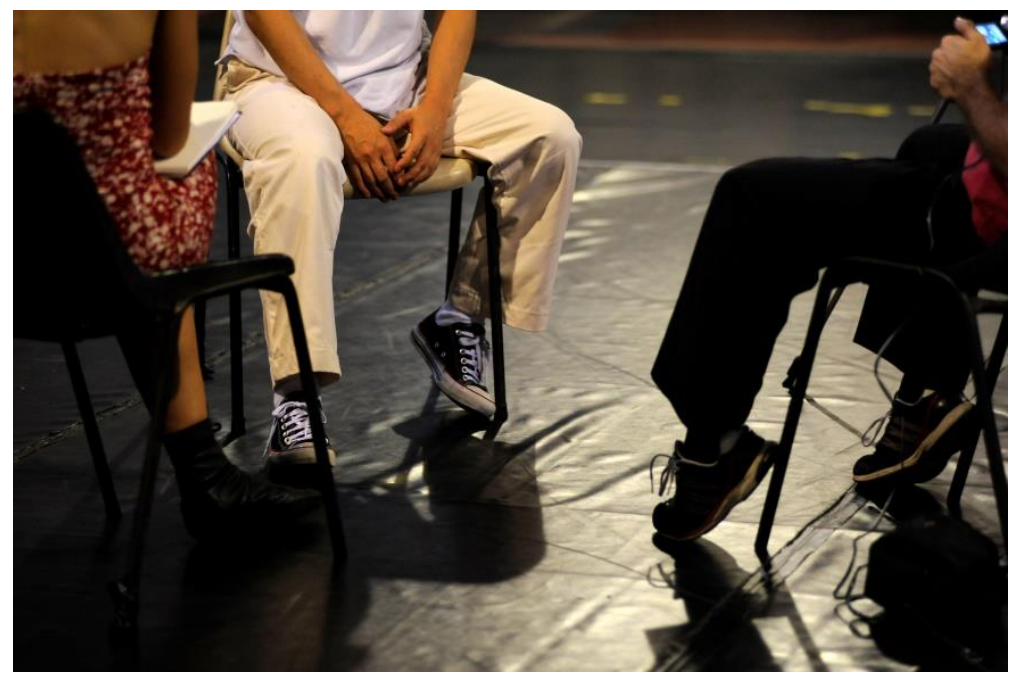

Fonte: Companhia Cênica Nau de Ícaros. Foto: Chris Von Ameln.

Ao longo do processo inicial do projeto Tirando os pés do chão foram realizadas 20 "ações performáticas", e foi possível realizar aproximadamente 140 entrevistas com o público que assistiu e participou destas ações. Os conteúdos e materialidades apreendidos nestas entrevistas estruturaram toda a pesquisa.

Neste contexto não poderíamos organizar esta gênese de forma diferente, ou seja, as perguntas que fizeram parte das entrevistas das "ações performáticas" convocarão os assuntos a serem desvendados.

\subsection{Nelson Rodrigues coloca que o amor é eterno. E que o verdadeiro amor só acontece uma vez na vida. Você concorda? O amor e a realidade de Myrna}

O espetáculo Tirando os pés do chão, como parte constituinte de um projeto maior com o mesmo título, apresentou, em todas as etapas do processo de criação, diversos 
procedimentos que partiram das investigações a respeito da fisicalidade do corpo e dos adjetivos que envolvem o estado amoroso. Relacionados e desenvolvidos sob a ótica de Nelson Rodrigues ${ }^{92}$ e das cartas de seu livro Não se pode amar e ser feliz ao mesmo tempo (RODRIGUES, 2002), a pesquisa buscava retratar não só as vicissitudes do amor, mas também anos de investigação sobre parâmetros técnicos corporais próprios da Companhia. Essa pesquisa traduz uma exploração sobre a movimentação e a reorganização corporal num espaço da cena ampliado pela relação com os elementos do circo, da dança e do teatro.

Figura 44 - Flyer do espetáculo Tirando os pés do chão

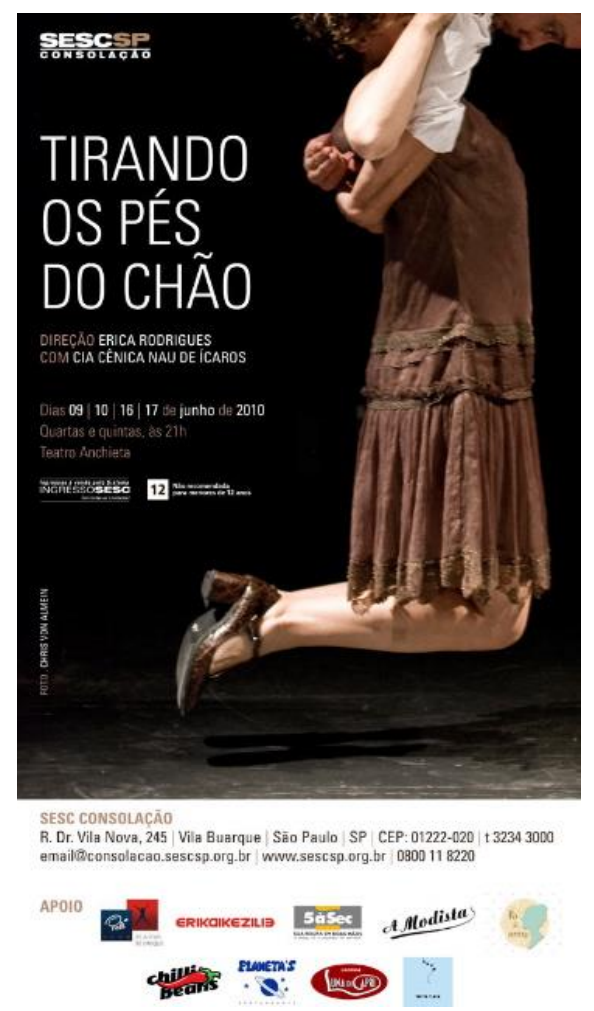

Fonte: Companhia Cênica Nau de Ícaros. Foto: Chris Von Ameln. Designer gráfico: Celso Reeks.

O texto de Nelson Rodrigues foi apresentado como inspiração inicial para a pesquisa e, no processo de criação, mostrou-se como uma ironia que conferiu um tom cômico

\footnotetext{
${ }^{92}$ Nelson Rodrigues (1912-1980) foi um importante escritor, jornalista e dramaturgo brasileiro. Revolucionou o teatro, com as peças, Vestido de noiva, Boca de ouro, A falecida, Toda nudez será castigada, entre outras. Teve a carreira marcada pela crítica, ao explorar a vida cotidiana do subúrbio carioca, com crimes, incestos e diálogos carregados de tragédia e de humor. (Disponível em: <http://www.nelsonrodrigues.com.br/site/materia.php?t=n\&c=4\&i=15>. Acesso em: 10 nov. 2016).
} 
necessário para falar de amor sem cair no lugar-comum do sofrimento absoluto ou nas imagens ligadas a um amor platônico. Foi um material provocativo e, através dos próprios conteúdos trabalhados pelo texto, foi possível estudar um amor mais real, no sentido de estar mais perto do público, e observar o que efetivamente acontece na vida cotidiana. Essa proximidade pode ser identificada na forma como o texto de Nelson Rodrigues se originou, que o escreveu sob o pseudônimo de Myrna, como informa Arnaldo Cortina (2004, p. 89):

[...] o discurso de Myrna nos revela que entre o ator que exerce a função de enunciador e a instância da enunciação pressuposta há um deslocamento. Myrna, o enunciador do texto, parece assumir um discurso feminino, mas na realidade esconde a perspectiva masculina. A coluna de Myrna, portanto, é uma paródia das colunas de conselho sentimental femininas. Por trás da voz de Myrna esconde-se uma outra, masculina, que, fingindo dar conselhos para valorizá-las, reafirma para as mulheres a aceitação do sofrimento, ou da infelicidade, como um estado contíguo ao do amor.

"Myrna escreve" nasceu em 1949, no Diário da Noite (RJ), e foi o segundo pseudônimo feminino de Nelson Rodrigues, que antes já havia utilizado Suzana Flag ${ }^{93}$. Era uma espécie de consultório sentimental que respondia a cartas de leitoras de todo o País, cujos textos foram selecionados e editados por Caco Coelho, com o título sugestivo Não se pode amar e ser feliz ao mesmo tempo. Não se sabe ao certo se as cartas eram verdadeiras ou inventadas pelo dramaturgo, jornalista e romancista, mas a característica de acidez das suas respostas e o fato de retratarem "a vida como ela é" 94 interessou à Companhia, que nesse projeto sobre o amor objetivava uma comunicação mais direta com o público. Este foi um dos textos utilizados no espetáculo Tirando os pés do chão:

O verdadeiro amor não pode ser integralmente feliz. Você sabe qual é o tremendo erro da maioria absoluta das mulheres? Ei-lo: achar que o fato de amar implica, obrigatoriamente, a felicidade. Quem ama, pensa que vai ser felicíssimo; e estranha qualquer espécie de sofrimento. Ora, a vida ensina, justamente, que duas criaturas que se amam, sofrem. Não por culpa de um ou de outro; mas em consequência do próprio sentimento. É exato que os amores têm seus êxtases de deslumbrantes, momentos perfeitos, musicais etc. etc. Mas eu disse "momentos" e não as 24 horas de cada dia. Quando uma mulher apaixonada se queixa, eu tenho vontade de fazer-lhe esta pergunta: "Não lhe basta amar? Você quer, ainda por cima, ser feliz?" Pois o destino, quando concede a graça inefável do amor, subtrai uma série de outras coisas. Antes de mais nada, o sossego. Quem ama, não tem sossego,

\footnotetext{
${ }^{93}$ Disponível em: <http://www.nelsonrodrigues.com.br/site/materia.php?t=n\&c=\&i=155>. Acesso em: 10 nov. 2016.

${ }^{94}$ A vida como ela é... é uma série de crônicas escritas por Nelson Rodrigues, durante os anos de 1950 a 1961. Era o nome da coluna diária do escritor no jornal Última Hora. Algumas cônicas foram reunidas em antologia sob o mesmo título da coluna em 1961.
} 
perdeu-o, para sempre. Se você tivesse uma maior experiência de vida Katia, saberia, é impossível amar sem sofrer. (Texto do espetáculo Tirando os pés do chão, inspirado em texto original de Nelson Rodrigues.edido pela Companhia Cênica Nau de Ícaros).

Nas entrevistas que compuseram o processo de criação, frases do texto foram inseridas no questionário, e depois as pessoas entrevistadas assistiam à cena com o texto de Nelson Rodrigues colocado junto às respostas gestuais que elas mesmas haviam dado e sobre o que achavam do texto. Todo esse complexo construído durante o projeto Tirando os pés do chão, estimulado por "Myrna", possibilitou às materialidades do texto serem somadas às imagens e gestos do público entrevistado. As experimentações acerca do tema revelaram e possibilitaram o desenvolvimento de desenhos espaciais que, através de partituras corporais e gestuais, traduziam o amor. E, mais do que isso, os traços das suspensões oníricas obtidas pelos relatos e as suspensões físicas de circo desses desenhos no espaço da cena se concretizaram.

\subsection{Você gostaria de participar de uma entrevista sobre o amor? Um processo compartilhado}

O projeto teve dois momentos distintos e complementares: na primeira etapa aconteceram as "ações performáticas" e, na segunda, a produção cênica do espetáculo Tirando os pés do chão. As "ações performáticas", como citado anteriormente, foram intervenções nas quais o público respondia a uma entrevista sobre o tema "estado amoroso", seguido de uma cena em que os atores-performers criavam uma partitura dos gestos das pessoas entrevistadas. Na sequência, essa partitura era executada e dividida com o público, no formato de improvisações.

A produção do espetáculo se tornou parte integrante do processo de criação, pois foi elaborado um método em que cada etapa foi compartilhada e também se autossustentou como produto artístico. Cada momento representou uma parte desse processo, que foi dividido com o público. Evidenciados pelos diversos espaços da cena, as entrevistas, as ações performáticas e também o espetáculo, na sua concepção final, possibilitaram o processo se autogestar. As etapas iniciais sustentaram as etapas seguintes e esse foi um modo de pensar a produção inédito para a Companhia. 
Ademais, Tirando os pés do chão foi criado em meio a duas circunstâncias marcantes: a primeira diz respeito à direção do espetáculo ser assumida por uma das integrantes da Companhia; e a segunda foi o fato do processo de criação ter sido realmente compartilhado com todas as pessoas envolvidas no espetáculo.

A criação de um espaço para Erica Rodrigues, que era integrante da companhia desde 1997, e que nunca tinha atuado na direção, assumir o papel de conduzir a pesquisa possibilitou à Companhia se desenvolver dentro dela mesma. Esse risco necessário, que tinha o desafio intrínseco que o próprio circo carrega, possibilitou à diretora navegar por lugares muito bem conhecidos, mas numa profundidade nunca antes alcançada pela Companhia. Foi um processo muito bonito e casual, um caminho que surgiu de maneira natural, no qual uma ideia deu lugar a experimentações que culminaram em um projeto e resultou em um espetáculo.

Ter o olhar de alguém que conhecia cada um dos integrantes profundamente potencializou a cena e estimulou a exploração dos espaços da cena de forma intensa e, ao mesmo tempo, intimista.

O Tirando os pés do chão [...] aconteceu de uma maneira natural e super solidária de todo mundo encarar, vamos aí! Vamos nessa! Me deram muita força, foi muito legal! Foi realmente emocionante. Isso foi uma coisa muito diferente, pois até então a gente não tinha vivido um processo como este [...]. Este foi um processo importante, porque isso estabelecia pra mim, que estava dirigindo, um conhecimento gigantesco de cada um com que eu estava trabalhando. Eu sabia o que cada um podia me dar de melhor. Isso muda muito, e para Companhia foi um ganho gigantesco. ${ }^{95}$

A característica determinante de ser uma criação que de fato foi compartilhada em todos os momentos destacou a importância do material humano trabalhado, pois em todas as etapas do processo, os atores-performers estavam ali, junto e ao lado da plateia. Afirmamos ser "compartilhado" não somente no sentido de dividir todas as impressões com o público participante, mas também deste participar deveras do processo.

As materialidades absorvidas através do compartilhamento só puderam ser realmente aproveitadas devido à veracidade com que foram capturadas. Ao realizar as entrevistas, que traduziam o interesse da Companhia pelo olhar do observador, nas suas histórias e impressões, o projeto deu importância para todo o material humano que estava borbulhando

\footnotetext{
${ }^{95}$ Entrevista de Erica Rodrigues, diretora do espetáculo, em 22 de julho de 2016.
} 
literalmente nos arredores da cena. Transformar o que o público tem a oferecer em inspiração e material foi a grande percepção do projeto.

Figura 45 - Entrevista, suspensão do entrevistado, gesto do entrevistado impresso no corpo do ator-performer e gesto observado durante ação performática
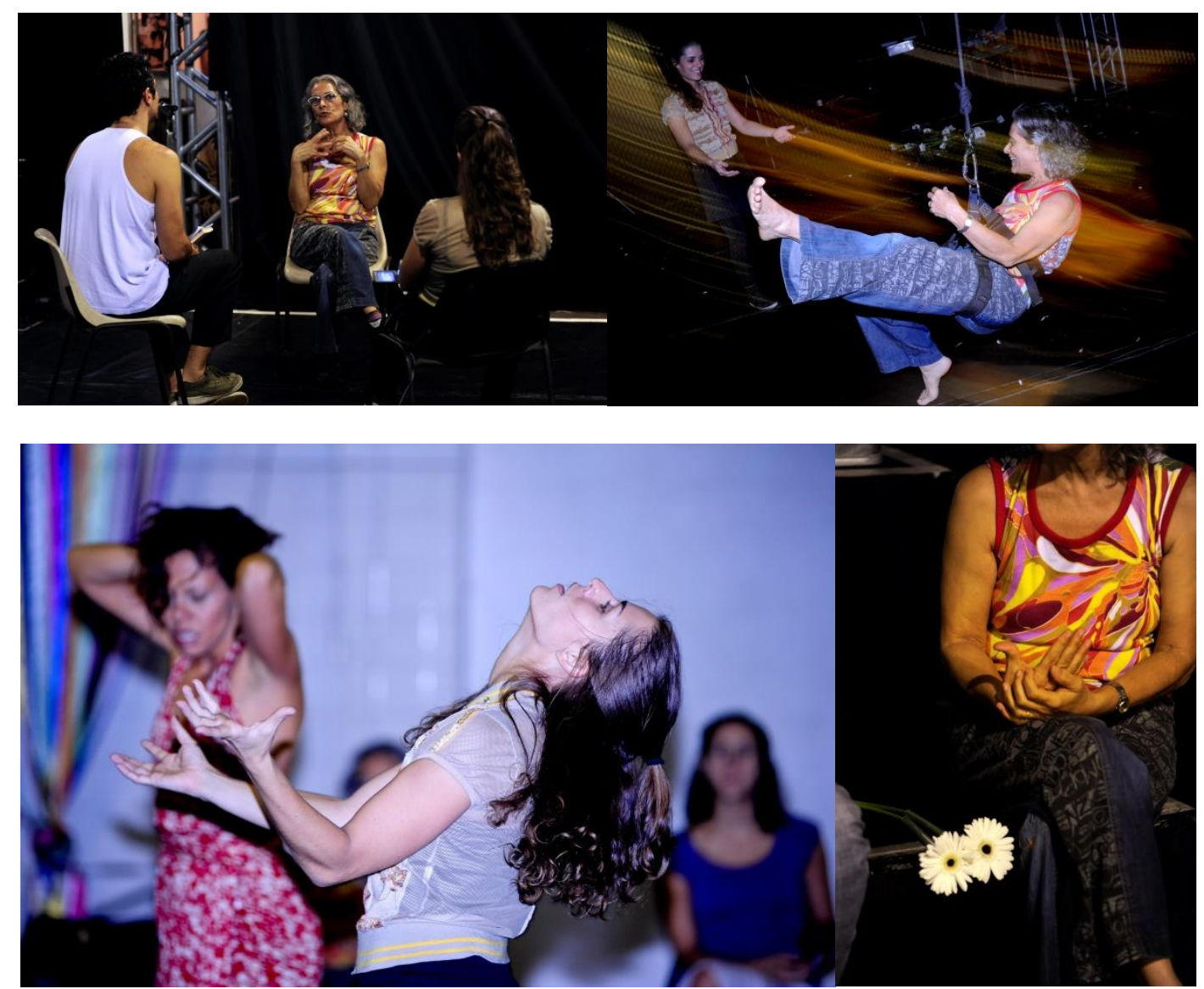

Fonte: Companhia Cênica Nau de Ícaros. Fotos: Chris Von Ameln

As pessoas entravam no espaço da cena e experimentavam o estado de suspensão, e nós contávamos para as pessoas o que elas haviam nos contado. O que tínhamos apreendido das entrevistas era colocado na cena, e um estado de surpresa e comoção era criado, pois o público estava se vendo através dos corpos dos atores-performers. Era algo muito diferente do que já tínhamos visto, e daquilo que já tínhamos produzido.

Essa participação dos atores-performers junto com o público também possibilitou aos integrantes da Companhia se despirem dos seus personagens mais frequentes. Quando isso foi de fato levado à cena na conclusão do processo, cada integrante da Companhia não era mais o mesmo, e sim composto por todos os personagens-públicos participantes. Não havia um personagem estabelecido, e sim uma memória afetiva daquilo que tinha sido vivido com todas 
as pessoas por meio das entrevistas. Da mesma forma, a exploração do espaço da cena também ganhou novas perspectivas e os desenhos no espaço foram elaborados sob a influência das materialidades absorvidas durante o contato com o público coadjuvante, observador e observado.

O meu corpo estava acostumado a cruzar o espaço da cena de um jeito, através de trajetórias habituais, e essa "interferência" ou inclusão do público me possibilitou estabelecer caminhos novos e transformados. Os meus gestos foram somados aos gestos adquiridos, ampliando os desenhos que eu realizava.

Figura 46 - Gestos obtidos das entrevistas sendo imprimidos pelo portô no volante

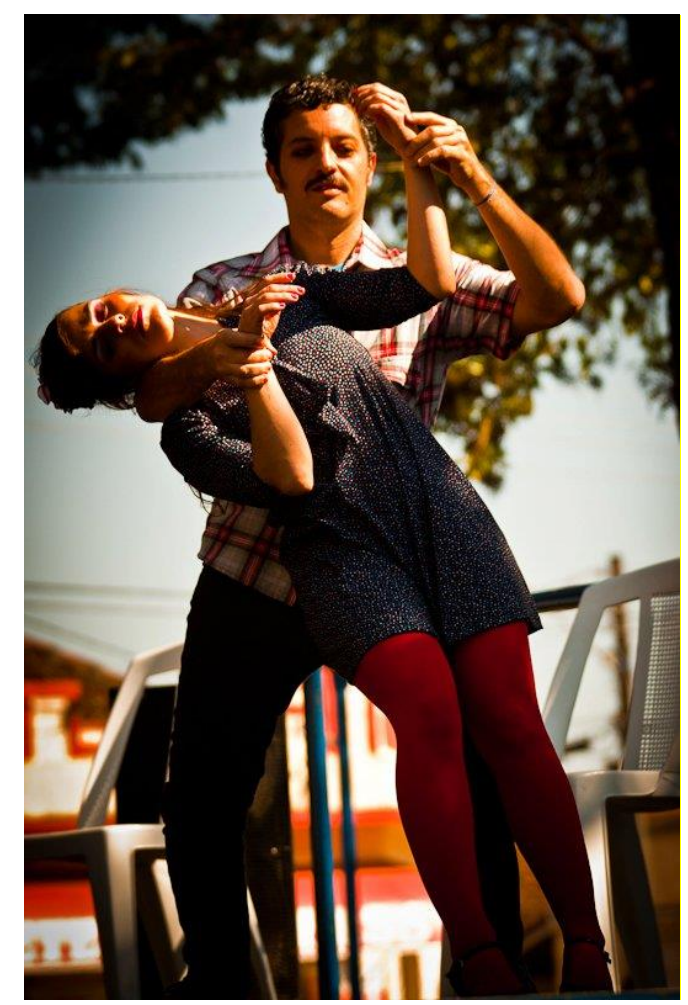

Fonte: Companhia Cênica Nau de Ícaros. Foto: Aldo Segnini.

Isso criou para nós do elenco uma proximidade verdadeira e intimista com o público. Era muito emocionante, pois as entrevistas nos impactavam de verdade, nós, os atoresperformers. Cada um dos intérpretes foi arrebatado pelo menos uma vez durante as entrevistas, a ponto de chorar por tamanha emoção vivida. Era um momento realmente lindo pois todos os envolvidos se abriam completamente. E, para a minha surpresa, e de todos nós da Companhia, as pessoas não ficavam encabuladas, constrangidas ou tímidas, como 
achávamos que ocorreria. As pessoas entrevistadas queriam falar, e cada vez mais; era como se tivéssemos aberto um lugar do "aqui você pode falar sobre amor". E havia realmente muito para se falar

Como intérprete-criadora, participar desse espetáculo foi realmente marcante, pois os momentos que vivi reverberam até hoje. Pessoas que eu entrevistei passaram a ser observadas com um outro olhar, mais intimista, e uma cumplicidade veraz foi criada. Gestos que observei e imprimi no meu corpo se tornaram significativos e inesquecíveis.

No começo do processo de criação, escolhemos pessoas muito próximas para realizar as primeiras entrevistas. Eu fiz a minha primeira entrevista com uma amiga que estava grávida; hoje, depois de mais de seis anos, tenho a dimensão de que aquela primeira entrevista ampliou minha visão sobre o amor de uma maneira arrebatadora.

Depois vieram as pessoas desconhecidas, com suas novas impressões sobre o amor. E, no final de todo o processo, eu não era mais a Bia, eu era Laura, a Célida, o seu Rubens, a Cris, a Lúcia do texto do Nelson Rodrigues, e tantos outros. Eu era um pouco do que cada um daqueles que havia me falado sobre o amor. As concepções e realidades sobre o estado amoroso que eu não havia vivido e que me foram contadas se misturaram às minhas vivências, ampliando minha visão sobre o tema. Eu me colocava no espaço da cena de maneira diferente, pois o processo possibilitou aproximar-me das histórias dos outros, trazer outros movimentos para o meu corpo. As minhas materialidades foram somadas às materialidades dos outros e colocadas no espaço da cena.

Importar histórias e gestos e, ao mesmo tempo, rever as suas próprias histórias e gestos criou um reconhecimento no outro ainda não experimentada pela Companhia até aquele momento. Cada ator-performer se reconhecia no público e o público podia se reconhecer nele. O espaço da cena se misturava ao lugar físico onde haviam acontecido as trocas e os compartilhamentos das entrevistas, através dos gestos identificados. Tirando os pés do chão representou uma maneira de verticalizar e aprofundar o trabalho, sem se distanciar do público.

Observando a produção da época na cidade de São Paulo ${ }^{96}$, de teatro e dança, foram identificados processos que se caracterizavam por serem quase mais interessantes para quem estava fazendo do que para quem assistia. Excluir o público desse processo não era uma coisa

\footnotetext{
${ }^{96}$ Produções atribuídas a um contexto cultural particular referente à dança e ao teatro na cidade de São Paulo, no período que vai do ano de 2000 ao início de 2010, ano de princípio do Projeto Tirando os pés do chão.
} 
que nos encantava na época, mas, pelo contrário, havia uma indagação de como incluir de forma verdadeira o público no processo de criação.

As indagações de como formar público para o circo, inserindo os novos processos criativos que diferem do tradicional eram questionamentos que contribuíram para se criar um processo que foi muito rico em todas as suas etapas e que pressupunha um pensamento: de que adiantava ensinar circo, dança ou teatro, se não se orientar como ver o circo, a dança e o teatro? Esse olhar de observação incluía as ferramentas criativas do próprio público e contribuía para entender os signos e os códigos criados por outras pessoas, além de nós, da Companhia.

Como eu vou comunicar sobre o amor com gestos só meus? Era uma questão que percorreu todo o processo do espetáculo. Queríamos um espetáculo que tivesse mais público, não no sentido quantitativo, mas sim qualitativo, que não fosse desinteressante, e que todas as materialidades da cena se aproximassem de fato desse público.

Havia também uma preocupação com a distância do público, que normalmente é provocada pelas ações que o circo desenha no espaço da cena, e que em um primeiro olhar podem parecer impossíveis. O corpo que desenha o inimaginável em um espaço impossível se apresenta como uma força ambígua e complementar na cena circense, pois, ao mesmo tempo que distancia, também cria um encantamento e uma atração. A questão era: como estabelecer uma relação mais próxima com o público através de ações extraordinárias, e que muitas vezes são consideradas sobre-humanas pelos signos e códigos que o circo apresenta? Como aproximar o público através das suspensões, sem delimitar isso apenas como uma ação única e exclusivamente possível para os atores-performers e seus corpos excepcionais?

\subsection{Onde você sente o amor fisicamente no seu corpo? As ações performáticas}

Nesse processo de comparticipação, as "ações performáticas" foram intervenções criadas com o intuito de aproximação com o público e, ao mesmo tempo, um processo de pesquisa compartilhado de forma imediata.

Eram realizadas em um espaço público, no qual as pessoas eram convidadas espontaneamente a responderem a uma entrevista. A partir das entrevistas, as pessoas, ao 
serem questionadas sobre o amor, falavam não só por meio de palavras e imagens, mas também por gestos que eram feitos ao responder à entrevista. Uma partitura dos gestos das pessoas entrevistadas sobre o tema "estado amoroso" era desenvolvida e imediatamente executada e dividida com o público pelos atores-performers, no formato de improvisações.

Figura 47 - Gestos e movimentos obtidos durante as entrevistas

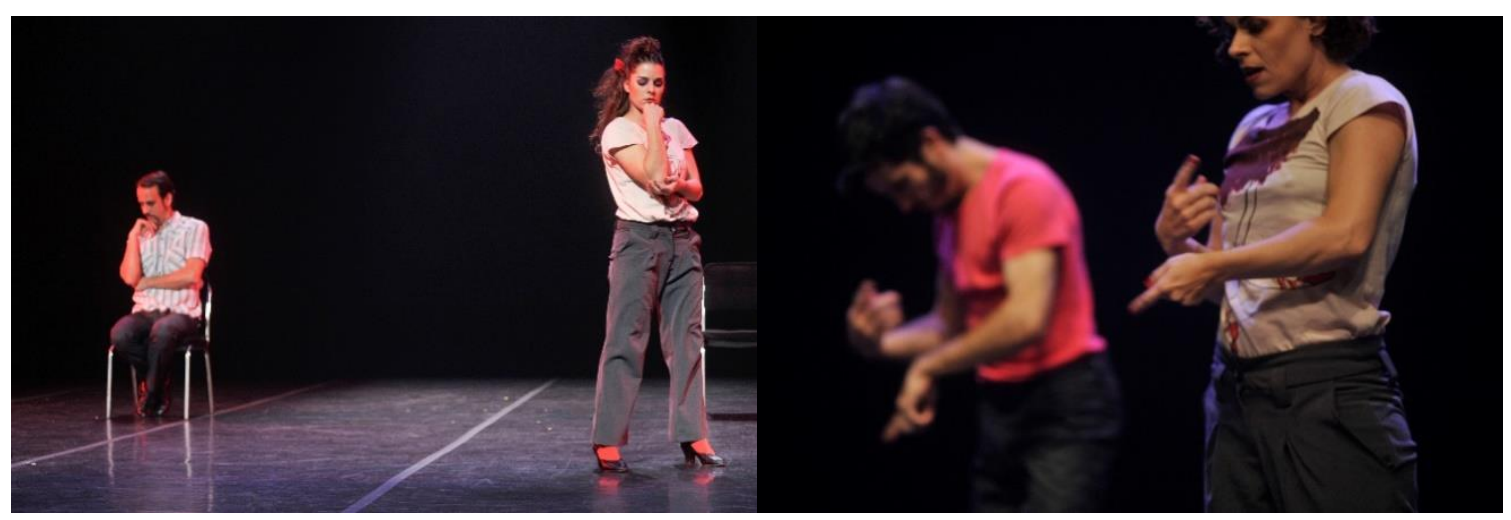

Fonte: Companhia Cênica Nau de Ícaros. Fotos: Chris Von Ameln.

A relação de mobilização do corpo como portador de teatralidade e seus sistemas significantes, neste projeto, é apresentada pelos limites dos corpos exibindo e desenhando o espaço, e criando uma performatividade coletiva (FÉRAL, 2002, p. 101). Esta relação pode ser traduzida no momento em que a reprodução desses estados amorosos são frações de ações e comportamentos de pessoas reais que estavam ali, naquela hora, presentes, e colaboraram nas entrevistas com seus gestos e imagens para a pesquisa.

O questionário das entrevistas ${ }^{97}$, elaborado pela diretora do projeto e por uma psicóloga, sobre o tema "amor", somava de maneira cuidadosa os assuntos do livro Não se pode amar e ser feliz ao mesmo tempo, de Nelson Rodrigues, a perguntas comuns sobre trabalho e escolhas, por meio das quais os entrevistados se colocavam no estado de "doadores" de olhares sobre o amor.

Igualmente ao fato de Myrna responder no texto a diversas cartas de leitoras do Diário da Noite sobre suas questões amorosas, apresentou-se também como inspiração para as entrevistas. Por diversas vezes, as respostas de Myrna, ou de Nelson Rodrigues, eram lançadas através de novas perguntas aos leitores.

\footnotetext{
${ }^{97}$ Questionário das entrevistas realizadas nas “ações performáticas” se encontra em anexo.
} 
Figura 48 - Primeira ação performática na unidade Pinheiros do Sesc São Paulo

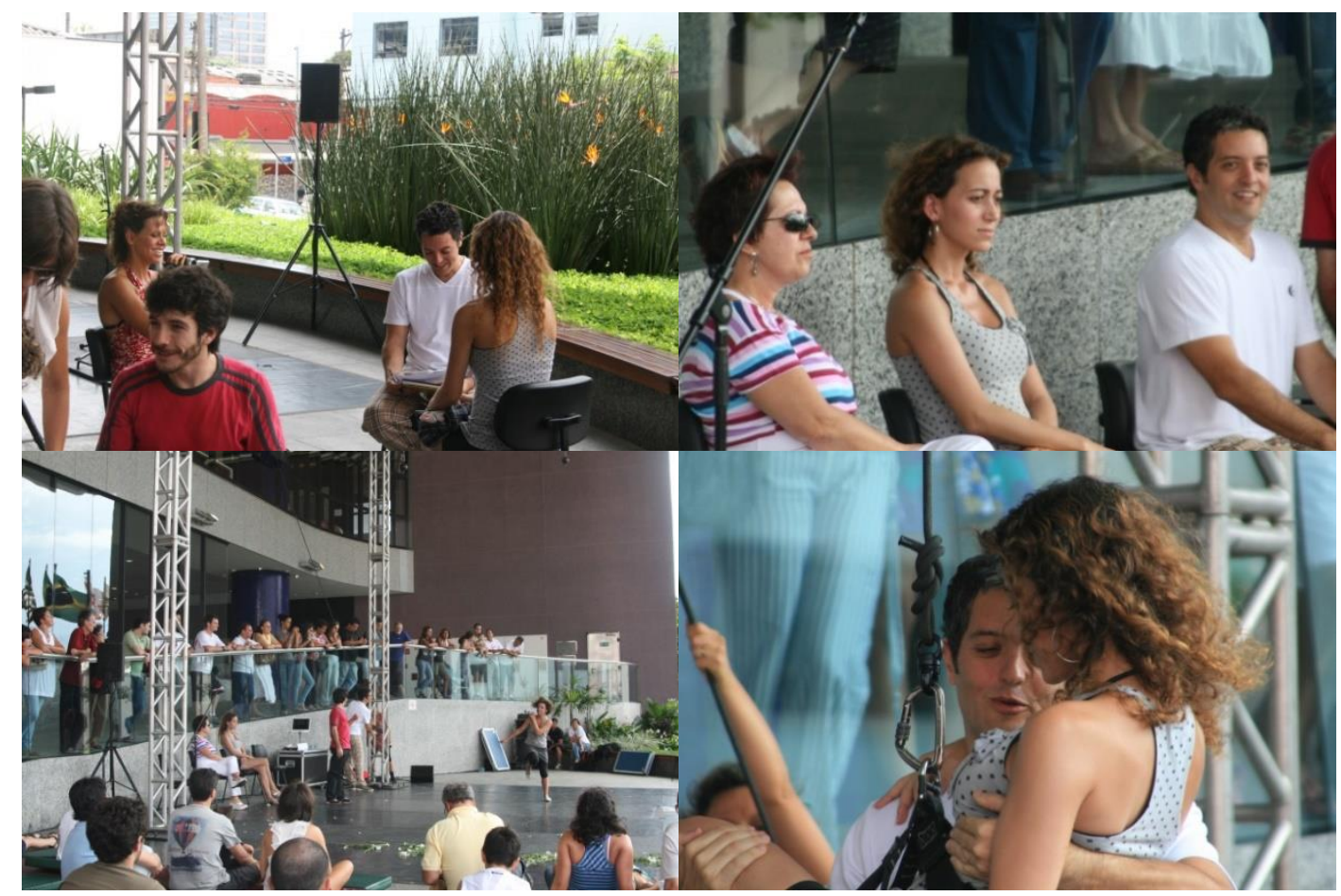

Fonte: Companhia Cênica Nau de Ícaros. Foto: Chris Von Ameln.

\subsubsection{O amor faz a gente perder a cabeça? Ele cega ou esclarece? As entrevistas}

No caminho de um processo compartilhado em que a inclusão do público fosse efetiva, a ideia da direção de elaborar o questionário para realizar entrevistas proporcionou um grande material para a pesquisa. Era um material emotivo, gestual, narrativo e também espacial, porque um dos objetivos das entrevistas era exatamente observar não só as histórias sobre amor, mas também os gestos poéticos que as pessoas faziam ao falar sobre o amor. Esses gestos não só foram observados e replicados, como serviram de inspiração para partituras corporais que influenciaram o desenho da cena.

Entendem-se como gestos poéticos ${ }^{98}$ :

[...] aqueles que nos estimulam e que permitem diferentes percepções e representações de nós mesmos e do mundo, não são explicáveis, e nem como as articulações, previsíveis, nem tão pouco literalmente traduzíveis;

\footnotetext{
${ }^{98}$ O termo gesto poético, emprestado de Andréa Bergallo Snizek, traduz a potência dos gestos que foram estudados e apreendidos durante as entrevistas realizadas durante o projeto Tirando os pés do chão.
} 
carregam sempre algo de indizível, misterioso, como se parte de sua materialidade fosse invisível. O que não vemos é o que nos faz seguir questionando e experimentando novas perspectivas, novos gestos, novas estratégias de comunicação, relações, coabitações (SNIZEK, 2012, p. 172).

A psicóloga Roberta Kovac ${ }^{99}$, convidada pela diretora, acompanhou todo o processo das entrevistas, principalmente na fase de elaboração do questionário, no sentido não só de que perguntas fazer, mas como fazer essas perguntas.

Num primeiro momento, a diretora preparou o questionário pensando em como parar uma pessoa em seu trajeto comum, no meio da rua; ou, no caso das primeiras ações performáticas, no meio de uma das unidades do Serviço Social do Comércio (Sesc). Levando em consideração o tema, que já chamava atenção por ser um assunto de grande acesso, o desafio era como fazer perguntas pessoais a uma pessoa desconhecida no meio de um espaço público.

Uma preocupação inicial na elaboração das perguntas foi sobre até que ponto se poderia entrar na vida das pessoas participantes. Os limites eram estabelecidos pela própria pessoa no momento que sentava para a entrevista, ou no momento em que era interrompida, num trajeto comum, com a interpelação: Você gostaria de participar de uma entrevista sobre o amor?

A entrevista se desenrolava por meio de perguntas que trilhavam um caminho com o objetivo de estimular que a pessoa produzisse algum material autêntico que fosse dividido com os atores-performers. O participante era inserido, no primeiro momento, em um espaço triangular, constituído por três cadeiras, dispostas de forma tal que durante a entrevista ficava de frente para dois atores-performers: um que fazia as perguntas e o outro filmava. Nesse momento, o espaço da cena já se estabelecia, pois além dos entrevistados, havia um público que assistia àquelas pessoas serem entrevistadas.

\footnotetext{
${ }^{99}$ Graduada em psicologia pela Pontifícia Universidade Católica de São Paulo (1995), é mestre em psicologia experimental e análise do comportamento pela Pontifícia Universidade Católica de São Paulo (2001) e doutoranda no Departamento de Psicologia Clínica da Universidade de São Paulo. É coordenadora e docente no Paradigma Centro de Ciências e Tecnologia do Comportamento. Tem experiência na área de psicologia clínica, atuando principalmente nos seguintes temas: terapia comportamental, eventos encobertos, trabalho no ambiente, equipe multiprofissional, RFT (teoria das molduras relacionais) aplicada à clínica e terapia de aceitação e compromisso. Também possui experiência em formação em psicologia e em análise do comportamento (Informações obtidas n seu currículo Lattes em 15.11.2016).
} 
Figura 49 - Relação triangular durante entrevista realizada na unidade Santana do Sesc São Paulo

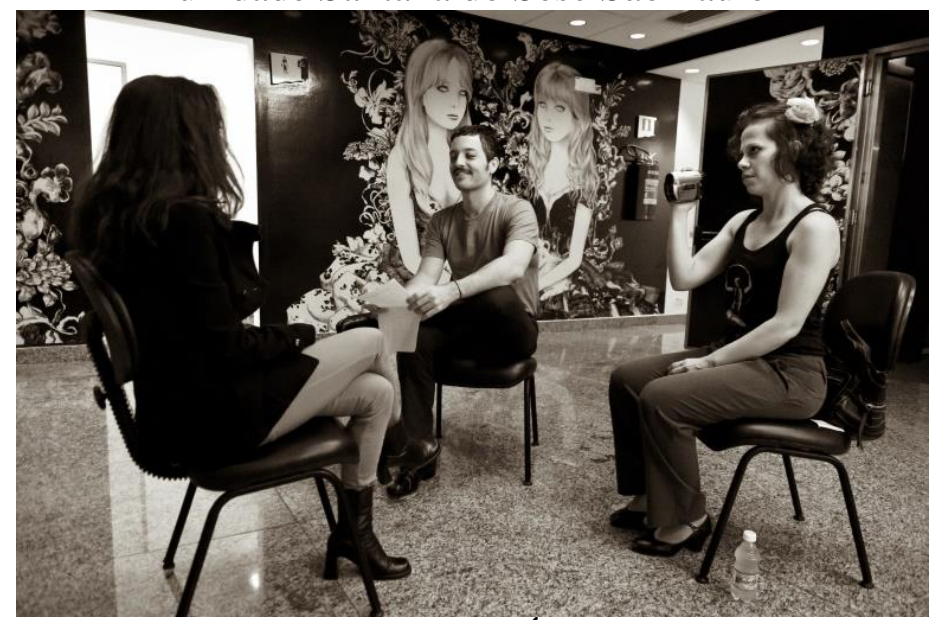

Fonte: Companhia Cênica Nau de Ícaros. Foto: Paulo Barbuto.

Tínhamos o cuidado de perguntar, mas sem sermos invasivos. O primeiro intuito era estabelecer o assunto "amor" como uma lembrança, com o objetivo de colocar a pessoa num estado de devaneio, para ela tentar lembrar como tinha sido aquele processo pessoal. Se trouxéssemos a pessoa para o momento atual, não obteríamos informações relativas ao processo de como o amor surgiu na vida daquela pessoa, como gostaríamos.

As primeiras perguntas não falavam do amor de forma direta, e sim do trabalho e de como a vida tinha se encaminhado para realizar determinado tipo de atividade. Isso contava um pouco sobre como a pessoa era e como ela lidava com o amor na sua vida.

O que você faz hoje, com o que você trabalha? Você sempre trabalhou com isso ou você fazia outra coisa? Como você resolveu, escolheu essa profissão? Você teria vontade de fazer outra coisa? O amor está presente na sua profissão? ${ }^{100}$

Quem trabalha com arte estabelece uma relação muito grande entre amor e trabalho pelo menos para mim isso é uma verdade - e o amor se torna material permanente para quem trabalha no meio artístico. No circo, o amor sempre esteve presente na formação das primeiras famílias; é como se o amor mantivesse todo o universo do circo, seja o prazer e gosto pela prática, seja o contexto familiar, no qual o amor sempre foi responsável pela continuidade e preservação das artes do circo.

Nas entrevistas que inauguravam as ações performáticas, os atores-performers entendiam um pouco quem era aquela pessoa à frente deles, através do nome, da idade e da

\footnotetext{
${ }^{100}$ Perguntas do questionário elaborado para as entrevistas do projeto Tirando os pés do chão (cedidas pela Companhia Cênica Nau de Ícaros).
} 
profissão ou trabalho. Também era um momento de observar como eram os gestos daquela pessoa, que diziam muito mais que as palavras, e enunciavam traços sobre o que era o amor para ela.

Na sequência, perguntas sobre o estado amoroso de modo geral geravam lembranças do amor no seu sentido mais simples, desvinculado das relações afetivo amorosas. E depois a entrevista chegava ao amor que é carnal, sexual e material, no amor que suscita reações físicas no corpo.

Você se lembra da sua primeira experiência amorosa? Como foi? Como você sabia que era amor? Você acha o amor físico, emocional, racional ou irracional? Onde você sente o amor fisicamente no seu corpo? É uma sensação boa ou não? ${ }^{101}$

No momento em que se perguntava onde o amor estava no corpo, os gestos eram realmente o foco dos atores-performers, pois era pressuposto que naquele momento surgiriam materiais e gestos muito interessantes.

Nunca esqueço uma das entrevistas, e da minha surpresa quando recebi uma resposta de que a pessoa sentia o amor na ponta dos cílios. Foi um dos gestos mais belos e sutis sobre o amor que me foi oferecido. Mesmo sem a pessoa saber que estávamos observando os seus gestos, me senti presenteada com tamanha sensibilidade e sinceridade, e essa foi apenas uma das 140 entrevistas que realizamos ao longo do processo das ações performáticas.

Figura 50 - Movimento criado a partir do gesto de colocar a mão nos cílios, obtido em entrevista durante a "ação performática"

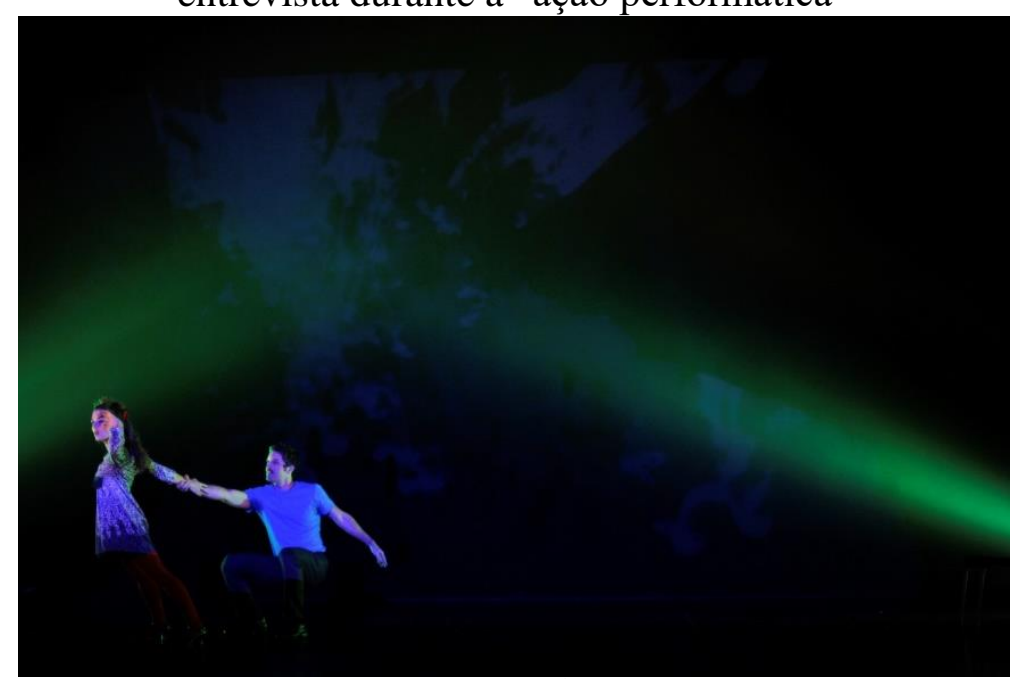

Fonte: Companhia Cênica Nau de Ícaros. Foto: Cris von Ameln.

\footnotetext{
${ }^{101}$ Perguntas do questionário elaborado para as entrevistas do projeto Tirando os pés do chão (cedidas pela Companhia Cênica Nau de Ícaros).
} 
Em alguns casos parecia que falar sobre o amor se tornava, ao longo da entrevista, uma grande alegria e diversão. O prazer de falar sobre aquele assunto era traduzido nos gestos fluidos e descontraídos. Mas também houve vezes que se instaurou uma grande tensão, uma angústia ou um choro, com gestos rígidos ou uma completa estagnação dos movimentos. Muitas vezes isso acontecia depois da pergunta: $O$ que te marcou mais, o amor ou o desamor? ${ }^{102}$

Durante as entrevistas todos os tipos pessoas cruzaram nosso caminho: pessoas descontraídas com milhares de gestos, pessoas tímidas com gestos minimalistas, pessoas vigorosas com gestos fortes e diretos, pessoas bêbadas com gestos descoordenados, pessoas idosas com gestos sábios e precisos, pessoas conhecidas com histórias e gestos desconhecidos; e outros tantos tipos, formas e desenhos. E sempre havia a última pergunta que elucidava toda a experiência vivida no momento de cada entrevista: $O$ que te tira os pés do chão?

\subsubsection{Você acha o amor físico, emocional, racional ou irracional? O espaço compartilhado}

A organização do espaço da cena aconteceu em um primeiro momento, como relatado, nas entrevistas. Os espaços abertos ao público, que aconteceram em grande parte em praças de convivência de unidades do Sesc São Paulo, possibilitavam às pessoas participarem ou simplesmente observarem uma cena bem clara: duas pessoas questionando uma terceira.

Como já dito, a princípio o espaço era corriqueiro, um triângulo delimitado por três cadeiras e uma câmera de vídeo. Mas ao iniciar a entrevista, essa composição espacial deixava de ser fotográfica e se tornava cena. A caracterização como um lugar que era ao mesmo tempo de interação e de observação foi determinado pela presença do público entrevistado, e também pelas pessoas que passavam, paravam e observavam a ação de entrevistar e ser entrevistado.

\footnotetext{
102 Perguntas do questionário elaborado para as entrevistas do projeto Tirando os pés do chão (cedidas pela Companhia Cênica Nau de Ícaros).
} 
Figura 51 - Entrevistas como lugar de interação e espaço da cena

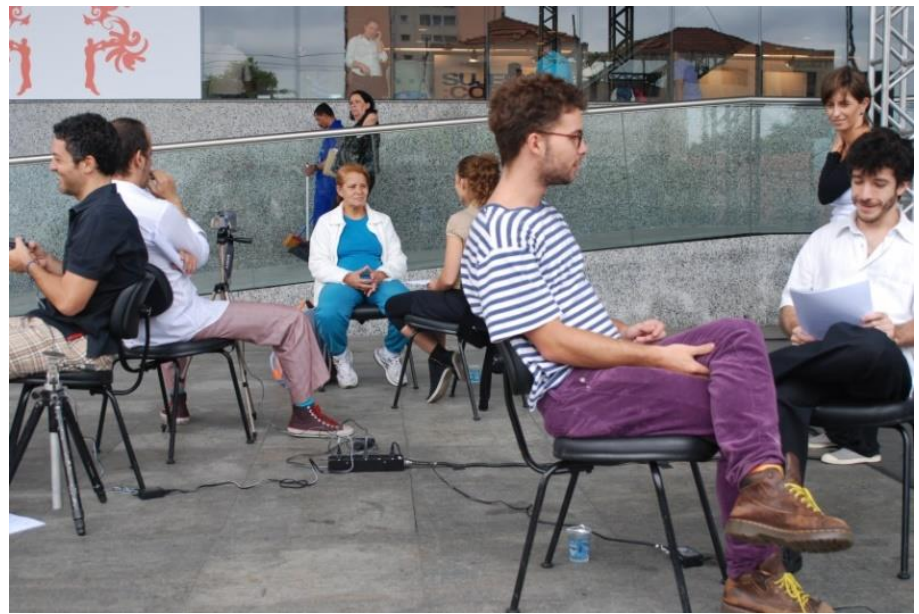

Fonte: Companhia Cênica Nau de Ícaros. Foto: Valéria Grzywacz

Após as entrevistas, em um segundo momento das "ações performáticas", o público/entrevistados tinham a oportunidade de observar os seus próprios gestos, imagens e falas.

Figura 52 - Gesto, entrevista e improvisação a partir do gesto replicado durante a ação performática

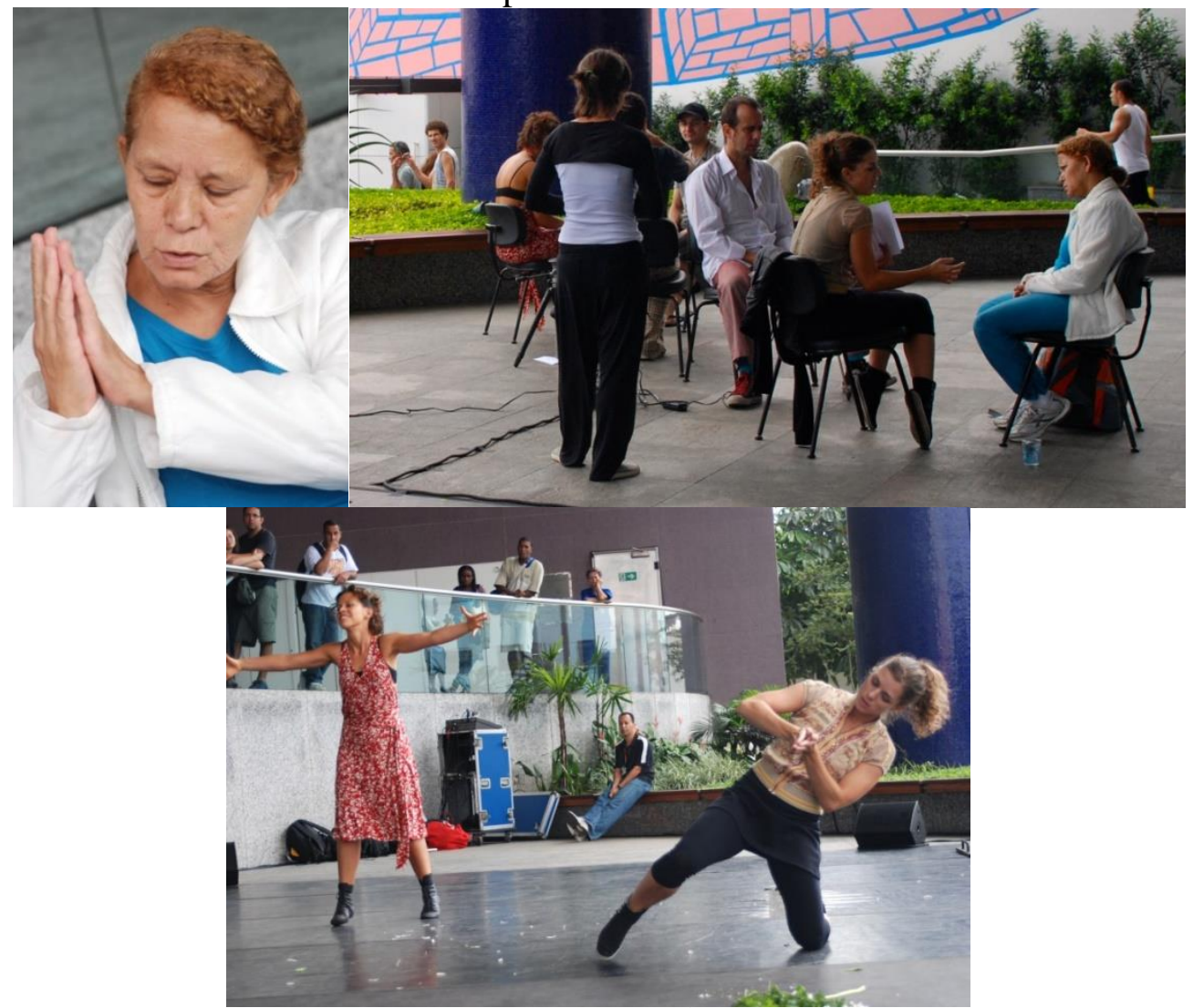

Fonte: Companhia Cênica Nau de Ícaros. Foto: Valéria Grzywacz 
Os atores-performers durante a entrevista observavam atentamente as materialidades oferecidas pelos entrevistados, principalmente os gestos que realizavam ao responder às perguntas da entrevista, e estes eram escolhidos e replicados na cena seguinte. Os gestos reproduzidos criavam possíveis identificações e imediatamente eram divididos/devolvidos ao público. Além disso, os gestos se ampliavam, criando desenhos, deslocamentos, imagens e outras materialidades que compunham um espaço da cena compartilhado.

Num terceiro momento, o espaço era "rompido" pela vinda do público para dentro da cena, quando os atores-performers convidavam algumas das pessoas entrevistadas para entrar e experimentar serem conduzidas de olhos fechados. E, posteriormente, podiam vivenciar o “estado de suspensão" por meio de equipamentos e cordas de alpinismo.

Figura 53 - Suspensão de um espectador participante durante a ação performática

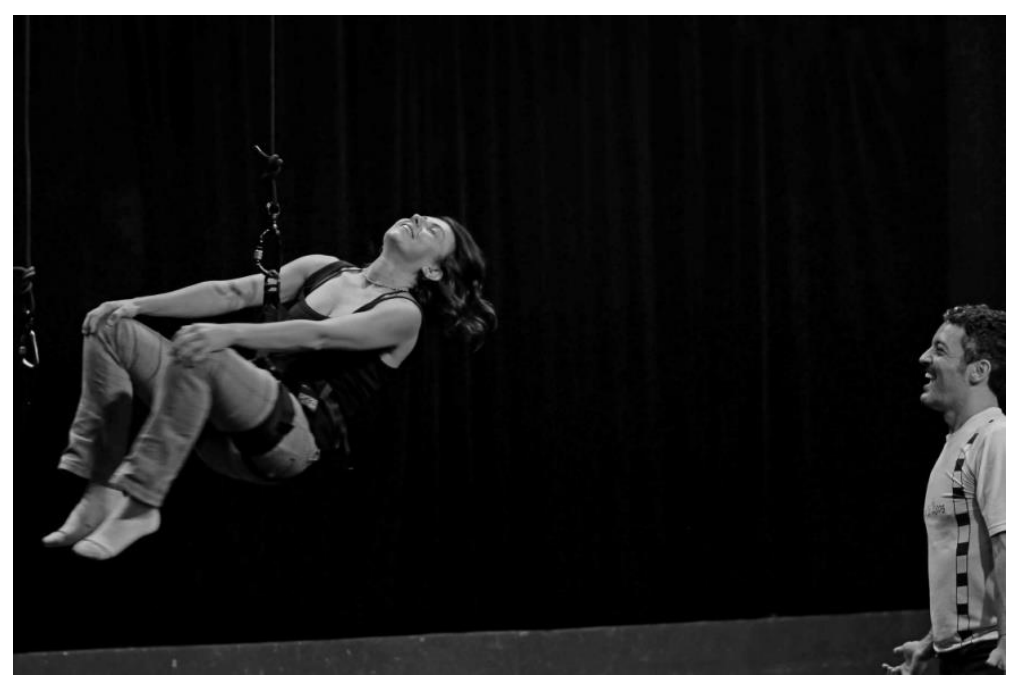

Fonte: Companhia Cênica Nau de Ícaros. Foto: Guilherme Yuji.

A relação entre significado e materialidade se dá a partir do momento em que os entrevistados "doam" aos atores-performers um material que é composto pelas respostas carregadas de sentidos pessoais.

Os gestos que essas pessoas faziam ao responder às questões sobre o amor, acompanhados de imagens e histórias, permitiam ampliar os sentidos e materialidades dos atores-performers que entram em cena para comunicar sentimentos e visões sobre o tema.

Em seguida, uma identificação por parte dos que assistem, que também são os entrevistados, amplia-se pelas trocas e sentidos expressos por aqueles corpos que revelam o 
que o outro contou sobre o amor. E se findava quando o estado descrito pelos entrevistados era experimentado e colocado no espaço da cena, sob o olhar e corpos dos atores-performers e suas suspensões.

A presença era instaurada não só pelos atores-performers, mas também pelo material humano doado a eles nas entrevistas, e identificado pelo próprio público com seus gestos, histórias e imagens vividas sobre o amor.

A estrutura cenográfica das "ações performáticas" e do espetáculo se desenvolveu junto com o processo de elaboração do projeto, no qual os aparelhos aéreos e a suspensão dos corpos possibilitaram o desenvolvimento de uma presença que compunha, e que transgredia, as materialidades do corpo, criando uma cenografia em movimento no espaço da cena.

A relação entre os movimentos no espaço da cena e as trocas entre os entrevistados e o atores-performers criou possibilidades que permitiram a ampliação das imagens e dos gestos extraídos das entrevistas, e destacou a presença participativa, por meio das suspensões, de quem executou e de quem observou.

Ao mesmo tempo que o público experimentou o "estado de suspensão" espacialmente, também havia o objetivo de que o público vivenciasse o estado poeticamente: através do estímulo de uma gama de sensações, boas ou ruins, que poderiam variar de acordo com a própria experiência de vida do espectador participante, sua relação com o tema amor e suas imagens internas, lembranças e medos.

Figura 54 - Gestos de entrevistas das ações performáticas do projeto Tirando os pés do chão

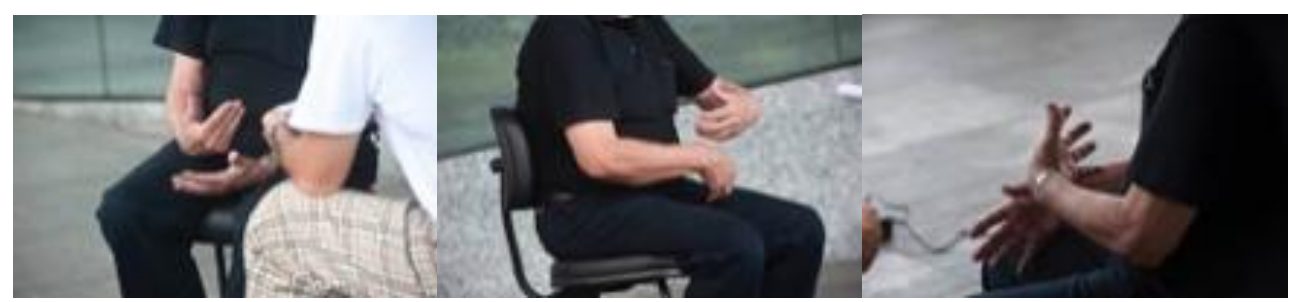

Fonte: Companhia Cênica Nau de Ícaros. Foto: Cris von Ameln.

Quando o espaço cênico é "rompido" e essa presença participativa é instaurada, há uma aproximação de todos os envolvidos nesse espaço, sejam eles participantes ou observadores. Essas "ações performáticas”, que a princípio serviram de insumo à criação, 
tornam-se de fundamental importância para a manutenção de uma qualidade corporal, chamada pela Companhia de "corpo-escuta".

\subsection{Como você sabia que era amor? - O espetáculo}

A segunda etapa do projeto, constituída pelo espetáculo Tirando os pés do chão na sua concepção final, resultou das experiências vividas nas "ações performáticas", dos gestos e imagens extraídos das entrevistas, das investigações acerca do corpo suspenso e dos textos das cartas de Nelson Rodrigues. Todas essas inspirações que se fizeram presentes no espetáculo são consideradas como materialidades da cena.

O espetáculo foi composto por cenas distintas que traduziam, além da pesquisa específica relacionada ao tema "estado amoroso", a diversidade de experimentações e técnicas que a Companhia explorou e somou aos seus movimentos desde a sua criação em 1992. Nas investigações da Companhia, a partir de 2002, surgiram os primeiros esboços de cenas de suspensão chamadas de eixos, que tinham como característica utilizar os equipamentos de alpinismo e os apoios dos corpos dos atores-performers uns nos outros, inclinados e em suspensão. Eram elevações que partiam desde suspensões sutis, a grandes voos no espaço da cena, e foram essas inspirações físicas que impulsionaram diversas cenas e modos de habitar o espaço. Foram esses equipamentos de alpinismo, aqui considerados cenografias em movimento, que também despertaram a vontade de "tirar os pés do chão".

Figura 55 - Espetáculo Tirando os pés do chão: cena dos eixos ou fantoche na corda

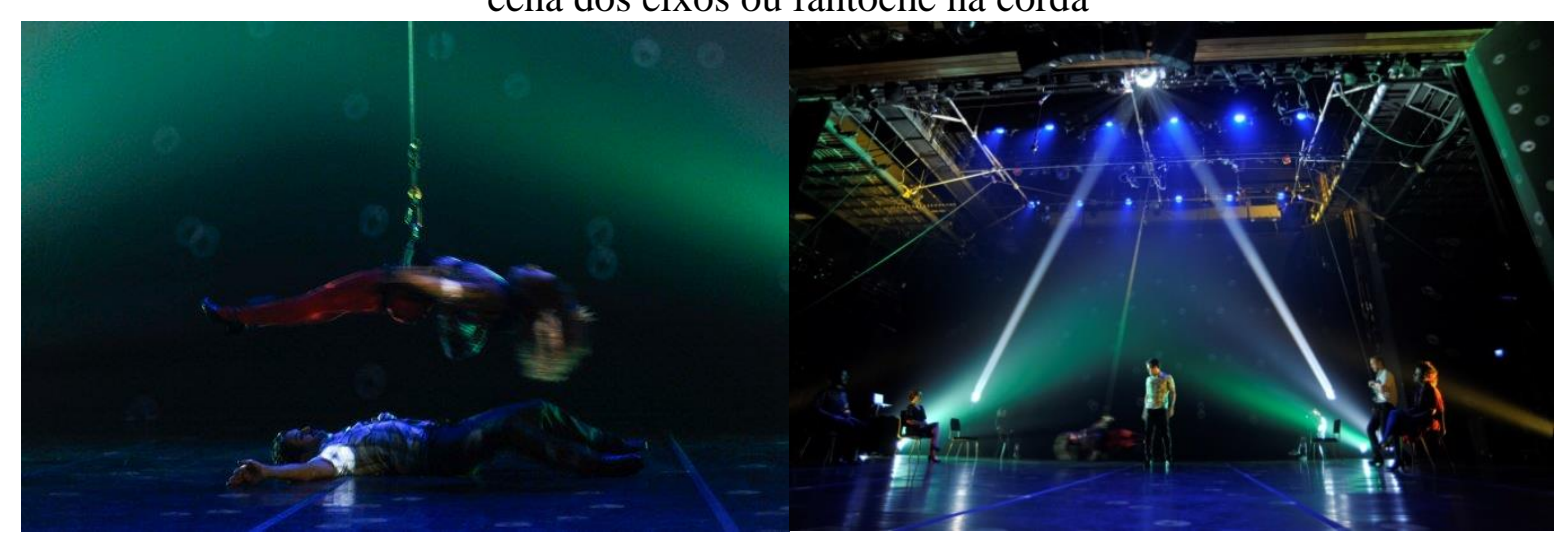

Fonte: Companhia Cênica Nau de Ícaros. Foto: Chris Von Ameln. 
O estímulo vindo dos elementos aéreos do circo também pode ser observado na estrutura da encenação do espetáculo, que seguia três eixos fundamentais desenvolvidos durante as investigações: o eixo real e concreto que envolvia as entrevistas e os entrevistados, o eixo chamado consultório sentimental, com referência às cartas de Nelson Rodrigues, e o eixo que envolvia a suspensão (do corpo, do tempo, da subjetividade) do estado amoroso.

O eixo real, que representava as entrevistas, e que foi revelado através dos gestos, das imagens e das falas dos participantes enquanto respondiam a questões sobre o amor, foi desenvolvido como uma partitura de gestos no espaço da cena. Elaborada pelos atoresperformers, essas partituras foram o ponto de partida para a construção coreográfica do espetáculo.

O eixo chamado de consultório sentimental ${ }^{103}$ trazia as cartas presentes no livro Não se pode amar e ser feliz ao mesmo tempo, correlacionadas aos "personagens"104 entrevistados e seus depoimentos, para criar uma espécie de dramaturgia que amarrou todo o roteiro do espetáculo.

O eixo da suspensão foi desenvolvido através das cordas de alpinismo, trapézios e lira, correlacionados com o estado de suspensão em que o amor nos coloca. Esse eixo traduziu a poesia, a subjetividade e as sensações emocionais e físicas experimentadas pelos entrevistados e atores-performers, quando confrontados com o tema. Apareceu no espetáculo justamente para criar uma contraposição ao eixo do concreto e real.

\subsubsection{Você é confiante ou é desconfiado? Fiar junto}

Os contextos macro e o micro da Companhia estavam totalmente juntos no espetáculo, pois tínhamos confiança na Érica como diretora do projeto, e em cada um de nós, integrantes e cúmplices de cena. Ao mesmo tempo, tínhamos confiança na história que o outro (público) nos oferecia, através de todo o material coletado e das referências doadas sobre o amor.

$\mathrm{Na}$ pesquisa, um dos aspectos que nos arrebatou foi exatamente essa relação de confiança - confiar: fiar junto -, no sentido de estar junto, de costurar histórias e

\footnotetext{
${ }^{103}$ Termo retirado do subtítulo do livro Não se pode amar e ser feliz ao mesmo tempo: o consultório sentimental de Nelson Rodrigues, na sua edição de 2002.

${ }^{104}$ Público que participou das entrevistas.
} 
movimentos. Na relação com os elementos aéreos do circo, a analogia com a confiança se identifica pela própria prática das técnicas de circo. Um ator-performer segura fisicamente o outro, o portô passa confiança ao carregar o volante, que entrega sua vida ao parceiro de cena.

Figura 56 - Cena em que portô carrega o volante no espetáculo Tirando os pés do chão

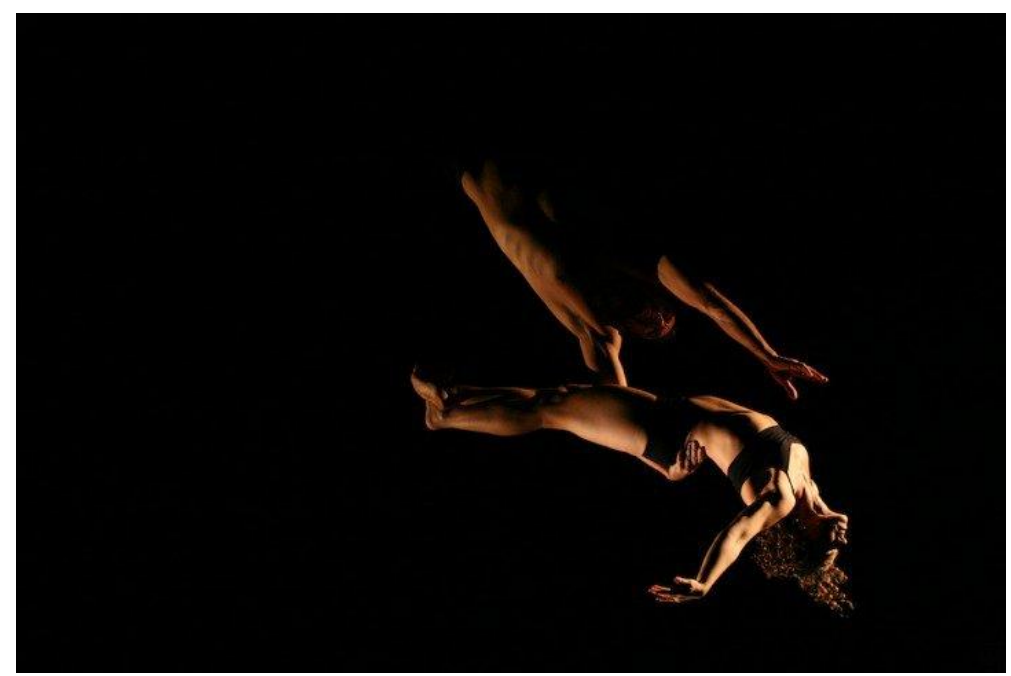

Fonte: Companhia Cênica Nau de Ícaros. Foto: Chris Von Ameln.

A dança e o circo também se uniram de maneira interessante no processo de Tirando os pés do chão, com outros sentidos para além da destreza. Uma outra poética foi alcançada, tornando-se um espetáculo que não estava voltado apenas para as soluções das técnicas do circo, mas sim para a poesia que podia ser expressa através dessas técnicas. Representou um diálogo entre prática e significado, entre materialidades objetivas e subjetivas, entre espaços objetivos e subjetivos, entre corpos e cenografias.

É de fato muito difícil se distanciar da técnica quando se trata de um espetáculo que envolve elementos aéreos de circo, no qual exatamente o risco de vida e morte é assegurado pela técnica. Mas o desafio no projeto Tirando os pés do chão se apresentou exatamente no sentido de como utilizar a técnica e valer-se dela para além da aparência e da segurança, de que modo fruir as habilidades técnicas como forma de ampliar as possibilidades poéticas da cena. Essa ampliação dos significados criou a oportunidade de novos desenhos no espaço da cena. 
Figura 57 - Cena em que se misturam elementos de dança e acrobacia no espetáculo Tirando os pés do chão

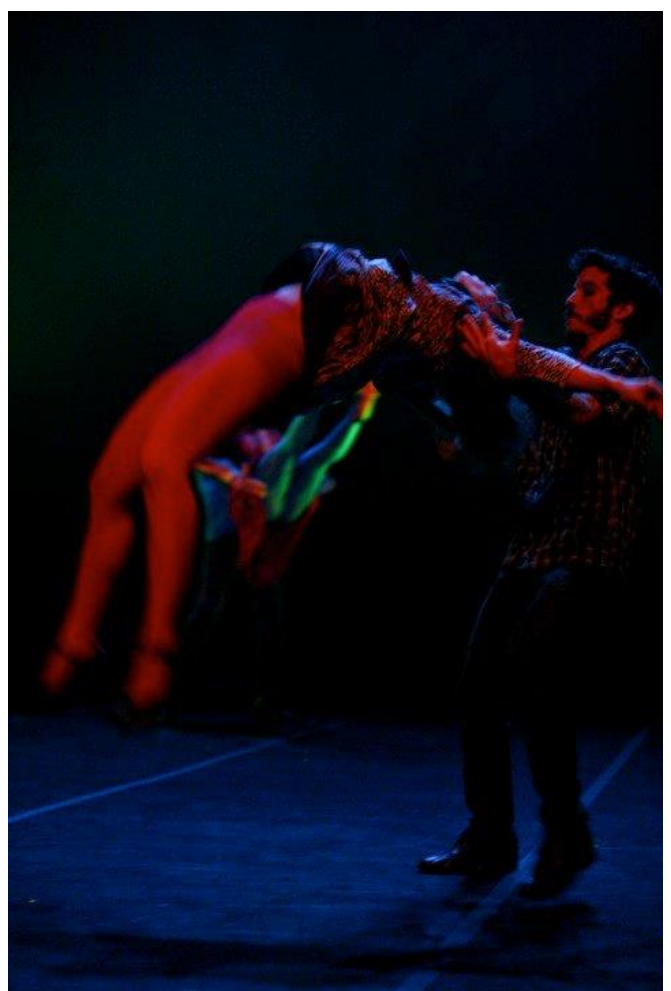

Fonte: Companhia Cênica Nau de Ícaros. Foto: Chris Von Ameln.

\subsubsection{Somos todos fantoches não escolhemos nem certo nem errado porque simplesmente não escolhemos... o que você acha? O espaço em movimento}

A presença dos elementos aéreos do circo nas cenas de Tirando pés do chão, em uma primeira análise, é fundamental para a relação de suspensão. Num aprofundamento dos conteúdos observados do processo de criação, os elementos aéreos trazem uma possibilidade de estar no espaço da cena ampliando a relação entre os atores-performers, as materialidades, o espaço e os observadores.

A cena inicial apresenta pequenas elevações que retratam todos os atores-performers tirando os pés do chão. Os equipamentos de alpinismo utilizados possibilitaram criar uma dinâmica de suspensão da cena, física e subjetiva. Nesse contexto, o espetáculo é inaugurado com a sensação inebriante e encantadora de tirar os pés do chão, acompanhada de uma brincadeira em que os atores-performers elevam uns aos outros. Essas imagens estabelecem uma relação de troca e de compartilhamento que caracteriza o próprio amor, e que o circo tem também como característica essencial. 
Figura 58 - Cena inicial do espetáculo Tirando os pés do chão
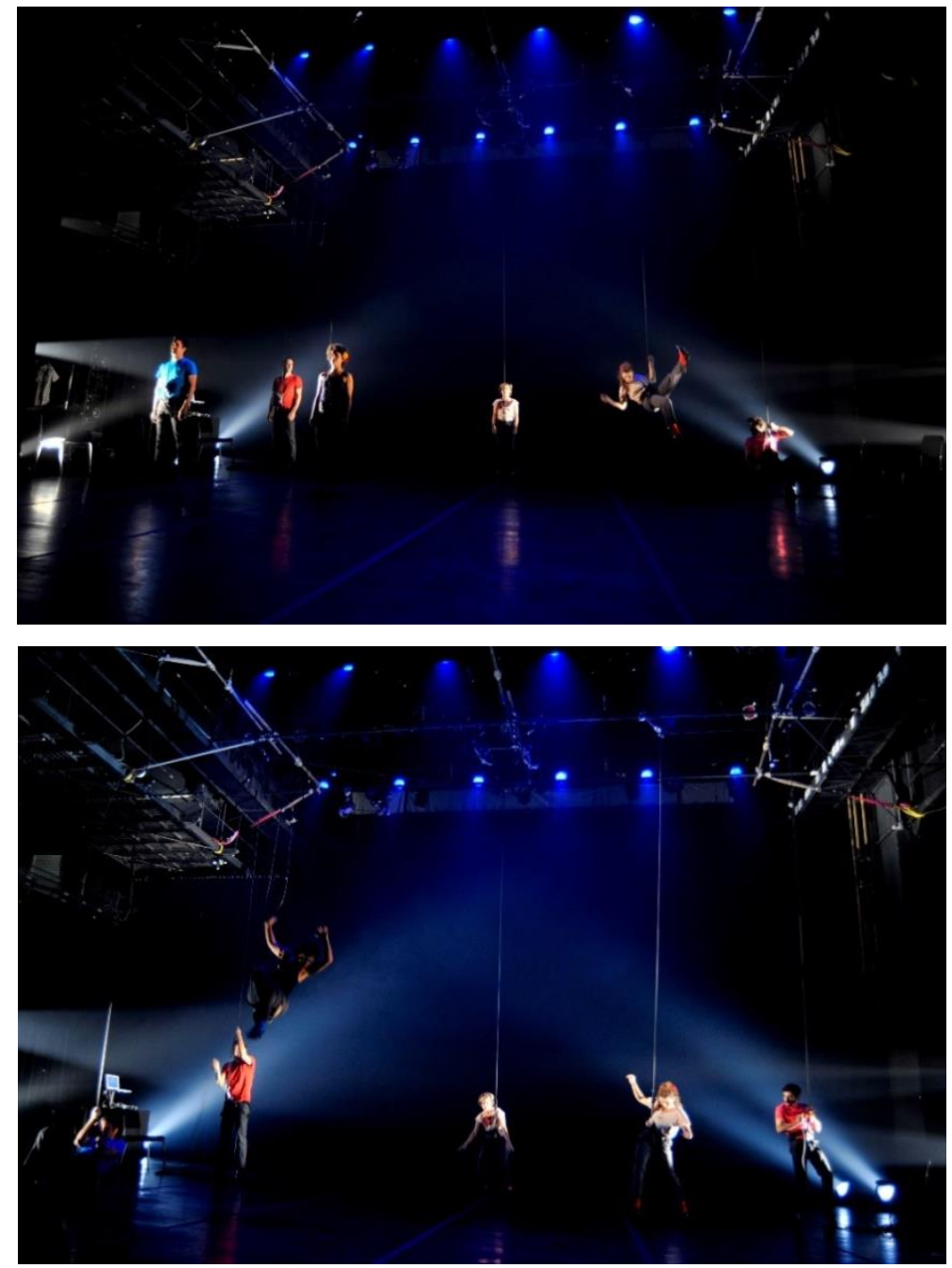

Fonte: Companhia Cênica Nau de Ícaros. Foto: Chris Von Ameln.

Ao pensar na exploração do espaço, houve algumas dinâmicas, exercícios e experimentações que se destacaram durante o processo de criação. Nas pesquisas acerca de possíveis ações que representassem o amor, observando pela ótica de um espaço em movimento, surgiu, a partir da frase de Nelson Rodrigues - "no amor somos todos fantoches, não escolhemos nem certo nem errado, porque simplesmente não escolhemos" (RODRIGUES, 2002, p. 33) -, um exercício de investigação chamado fantoche.

Esse exercício consistia em um portô conduzir o corpo do volante, que estava sobre o seu corpo através do espaço e dos seus gestos. O portô, mais do que carregar o outro, imprimia no corpo do volante os seus movimentos sobre o amor. $\mathrm{O}$ objetivo do volante era deixar-se conduzir e permitir aos movimentos do outro serem anexados ao seu corpo, através da entrega do seu peso ao outro. 
Foi um exercício de investigação muito poderoso, no sentido de apresentar muitos significados, que para a Companhia era necessário naquele momento. Mais que isso, era uma forma de estar em cena através das imagens projetadas pelo texto do Nelson Rodrigues. Essa potência encontrada nos fantoches se ampliou durante as ações performáticas, a partir das entrevistas. Nesse segundo formato, o portô deixou de imprimir no corpo do volante seu olhar sobre o amor e passou a reproduzir os gestos e o olhar de uma das pessoas entrevistadas.

Figura 59 - Exercício e improvisação Fantoche

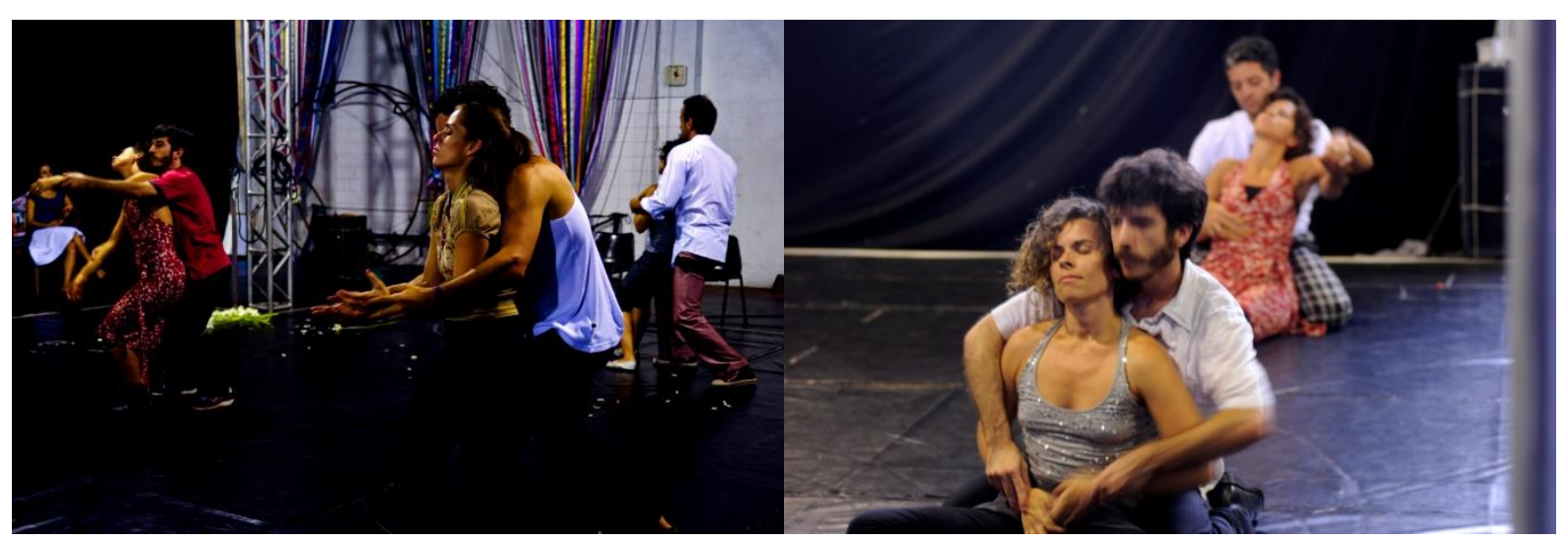

Fonte: Companhia Cênica Nau de Ícaros. Fotos: Chris Von Ameln.

No espetáculo, a cena dos fantoches se deu na forma de improvisação, possibilitando novos desenhos no espaço a cada apresentação. Essa dimensão efêmera traduzia o próprio sentimento do amor e possibilitava transitar por muitas referências e materialidades adquiridas e vividas durante as ações performáticas. Era uma forma de ampliar as ações e movimentos numa magnitude e riqueza de detalhes que traduzisse o que tinha sido adquirido durante todas as entrevistas do processo.

Novamente, no próprio espetáculo o exercício foi desenvolvido num terceiro formato, ao suspender o volante através das cordas de alpinismo. O corpo do ator-performer passou a ser conduzido por dois portôs: um que imprimia os gestos pelo toque e também realizava conduções espaciais no eixo da corda em que o volante estava, e outro, que controlava a corda de alpinismo na outra extremidade. 
Essa dupla portagem possibilitava não só conduzir o corpo do volante em diversas alturas pelo espaço, como também construir diversos desenhos na cena: desenhos gestuais no corpo do volante, desenhos horizontais no eixo da cena, e desenhos verticais ao subir e descer a corda. A composição da cena tinha as cordas e equipamentos de alpinismo como materialidades objetivas, aliadas à condução dos corpos em movimento, que imprimia as materialidades subjetivas, nas quais é possível identificar linhas invisíveis que desenhavam o espaço da cena.

Partindo desse pressuposto de que o movimento produz linhas invisíveis no espaço, a imobilidade poderia ser um ponto ou um conjunto de pontos desenhados. Os pontos estáticos se tornam dinâmicos a partir do movimento do corpo e há uma verticalidade que seria a união das linhas no espaço, marcada intensamente pela postura do corpo de pé, e definida pela coluna vertebral como a linha central e vertical do corpo no espaço.

Em uma experimentação de light painting ${ }^{105}$ no decorrer de um ensaio do espetáculo Tirando os pés do chão no Teatro Alfredo Mesquita, em São Paulo, durante a temporada de 2015, foi possível observar as linhas invisíveis que os corpos dos atores-performers desenham no espaço da cena.

Pontos imóveis de luz foram inseridos em uma indumentária paramentada com leds aplicados em pontos articulares, produzida especialmente para essa captação de imagem em movimento. A indumentária, aliada ao movimento, possibilitou produzir um vídeo ${ }^{106}$ e fotos que mostram exatamente o desenho no espaço que os corpos realizam, ao utilizarem técnicas circenses em aparelhos de acrobacia aérea.

A perspectiva criada ao gravar na superfície sensível (foto e vídeo) o movimento possibilita enxergar a fixação da luz em um espaço de tempo, de forma que cenografias que não são visíveis a olho nu puderam ser evidenciadas.

\footnotetext{
${ }^{105}$ Light painting é uma técnica de captura de movimento que consiste em desenhar com a luz sobre o dispositivo de captura fotográfico (filme ou dispositivo eletrônico), que possibilita gravar na superfície sensível o movimento, gestos e os desenhos no espaço. Ao revelar ou processar a imagem proveniente da captura, é possível enxergar a fixação da luz em um espaço de tempo (Disponível em: <http://www.neliufpe.com.br/wpcontent/uploads/2013/07/07.pdf>. Acesso em: 20 jan. 2016).

${ }^{106} \mathrm{O}$ vídeo deste experimento pode ser acessado em: <https://youtu.be/oPaIeE7bYCw>. Fotografia de Bia Ferrer.
} 
Figura 60 - Ligth painting da cena da lira e da cena dos eixos
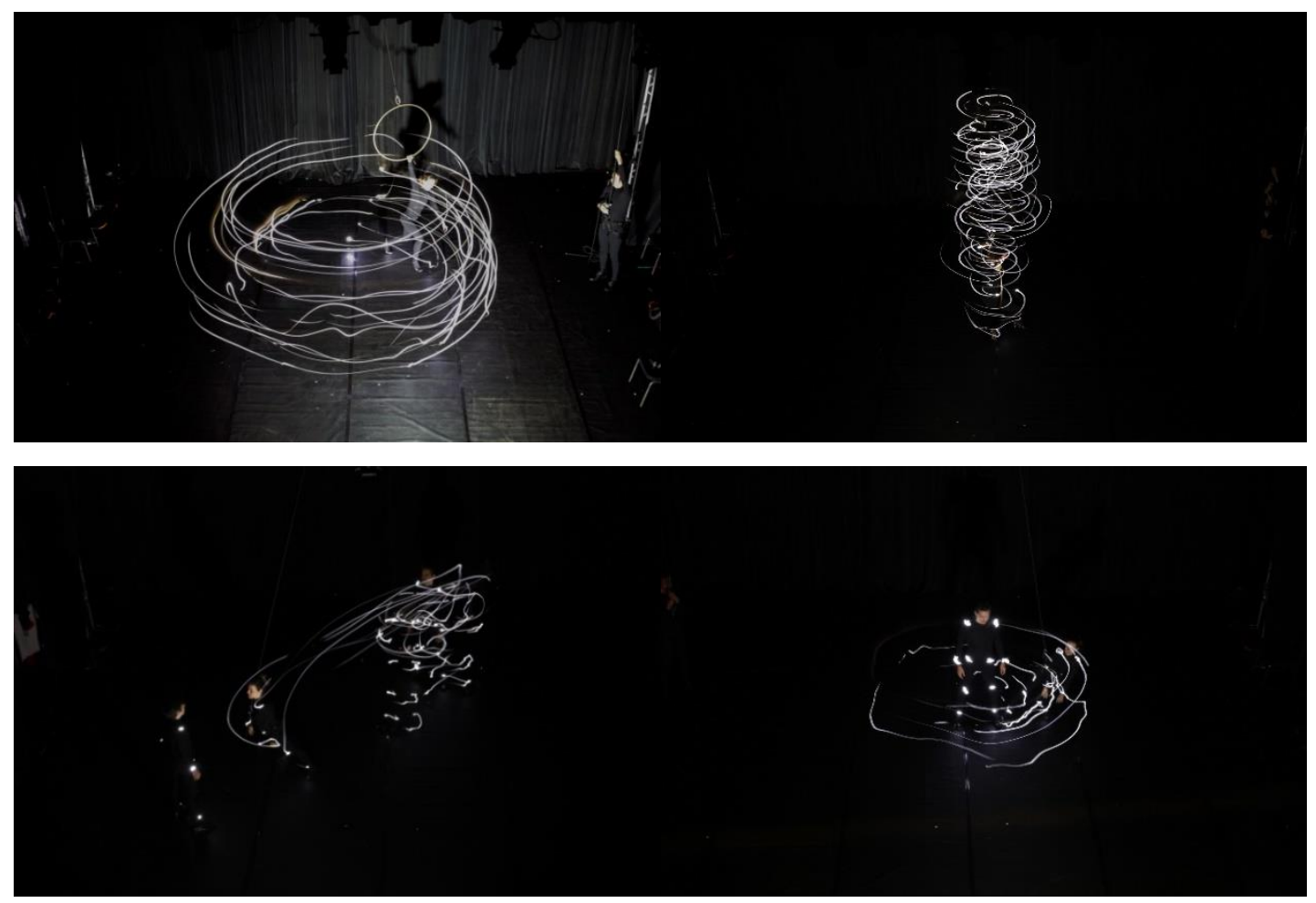

Fonte: Acervo da pesquisa. Fotos: Bia Ferrer.

Os elementos aéreos do circo, como cenografias que se relacionam com o corpo e movimento dos atores-performers no espaço da cena, criam uma matéria efêmera e transitória que está presente durante a ação. $\mathrm{O}$ espaço em movimento se torna tão importante quanto a matéria palpável; ambos são geradores de desenhos na cena, assim como ambos são cenografias em movimento. Por vezes, essa cenografia é visível, mas eventualmente, quando está em movimento, possui tamanha brevidade e velocidade que se torna invisível.

A diversidade de desenhos no espaço pode ser observada nas diferentes cenas de Tirando os pés do chão, através de ações ensaiadas com precisão, com a pretensão de delimitar o mesmo desenho no espaço, em todos os espetáculos realizados; ou também nas cenas de improvisação, nas quais os conteúdos episódicos possibilitavam novos desenhos a cada apresentação. As cenas que utilizavam elementos aéreos de circo possuem uma característica que combina tanto a precisão das cenas ensaiadas, quanto a inconstância assertiva das cenas improvisadas, numa ambiguidade interessante, quando se fala de um espaço em movimento.

A movimentação dos corpos dos atores-performers, somada aos elementos aéreos do circo, criam um desenho no espaço da cena que está relacionado diretamente com os efeitos 
da ação da gravidade. Assim como a relação da coluna vertebral como eixo corporal é singular e diferente a cada apresentação, principalmente na utilização de cordas de alpinismo, a relação com o espaço também apresenta uma variável. Por um lado, a técnica do circo exige uma repetição de ações, que está ligada à minimização do risco intrínseco, mas por outro, essa relação gravitacional e de eixo corporal altera a relação espacial. São variáveis muitas vezes sutis, mas caracterizam um desenho diferente a cada vez que a ação é executada.

A gravidade é a relação do nosso corpo com o espaço terrestre, é o que mantém o nosso corpo no chão. Há uma "luta" constante dos músculos antigravitacionais quando o corpo é suspenso. E esse confronto produz um movimento particular, e consequentemente produz linhas verticais, horizontais e diagonais invisíveis no espaço.

Figura 61 - Suspensão no espetáculo Tirando os pés do chão

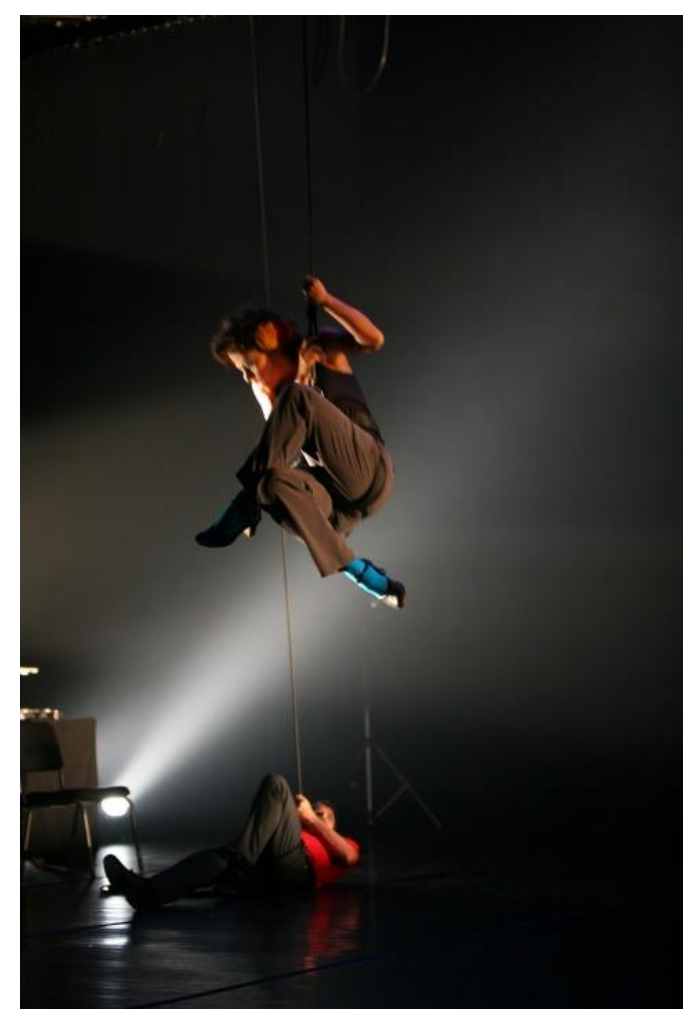

Fonte: Companhia Cênica Nau de Ícaros. Foto: Henrique Lenza

A verticalidade como uma sensação interior, subjetiva do corpo, ainda poderia ser definida simplesmente pela presença do corpo no espaço. Mas no caso do circo, essa verticalidade não é só a presença do corpo humano, mas também a do aparelho aéreo que é utilizado, e cria novos desenhos no espaço, quando relacionada ao movimento do corpo. 
O equipamento aéreo circense não está no espaço somente como objeto, e sim como uma cenografia ou uma materialidade, no sentido de que compõe o espaço da cena. A verticalidade destacada através dos movimentos dos corpos no ar e no aparelho aéreo remete à criação de um desenho composto de linhas invisíveis no espaço da cena, de uma cenografia em movimento.

A verticalidade é um marcador, ou a partir do próprio corpo, ou em relação aos elementos no espaço. É nos trabalhos em que a verticalidade dialoga com a gravidade que os atores-performers têm a possibilidade de revelar outros espaços e criar a percepção de outro tempo.

Os pontos estáticos dos aparelhos aéreos, considerados cenográficos, compõem o espaço em movimento junto com a verticalidade exaltada pelos corpos dinâmicos e as linhas invisíveis desenhadas. Essa relação da gravidade com verticalidade, que gera o movimento no ar, só é possível pela presença cenográfica dinâmica dos elementos aéreos do circo. As artes do circo propõem colocar nossa verticalidade em jogo, nos permite sair do solo para reinventar, tanto espaços, quanto conteúdos.

\subsubsection{Você conduz, ou é conduzido? Uma cenografia em movimento}

Durante alguns anos ${ }^{107}$, as produções da Companhia Cênica Nau de Ícaros tinham uma característica significativa que compõe o espaço da cena: a repetição de ações e visualidades. No caso do espetáculo Tirando os pés do chão, a reincidência de ações e signos faz parte do processo de criação e compõe diretamente a dramaturgia, assim como as características operacionais ligadas às composições no espaço e à própria técnica circense.

Partimos da afirmação de que os elementos aéreos do circo são utilizados como cenografias no sentido de serem materialidades que compõem e formam o espaço da cena.

\footnotetext{
${ }^{107}$ A partir de 2002, quando passei a fazer parte como intérprete-criadora da Companhia Cênica Nau de Ícaros.
} 
Figura 62 - Cena utilizando o aparelho aéreo lira e projeções de margaridas ao fundo

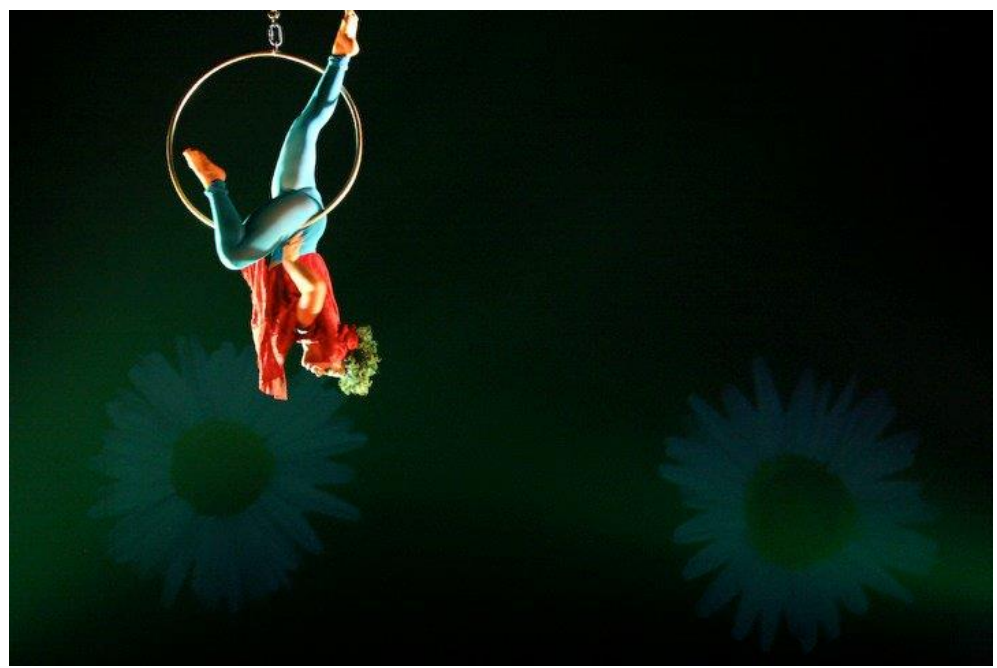

Fonte: Companhia Cênica Nau de Ícaros. Foto: Henrique Lenza.

Algumas brincadeiras de repetição de signos podem ser encontradas nesse espetáculo: Margarida é uma das leitoras-personagens de Myrna que aparece no texto; ao mesmo tempo, um vídeo revela margaridas flutuando no espaço da cena, que compõe a cenografia, junto a uma mulher dançando no ar em uma lira; e um buquê de margaridas é levado ao palco por uma mulher que brinca de bem-me-quer, mal-me-quer. Será ela Margarida? Será Myrna? Será Érica?

Figura 63 - Cena do espetáculo Tirando os pés do chão

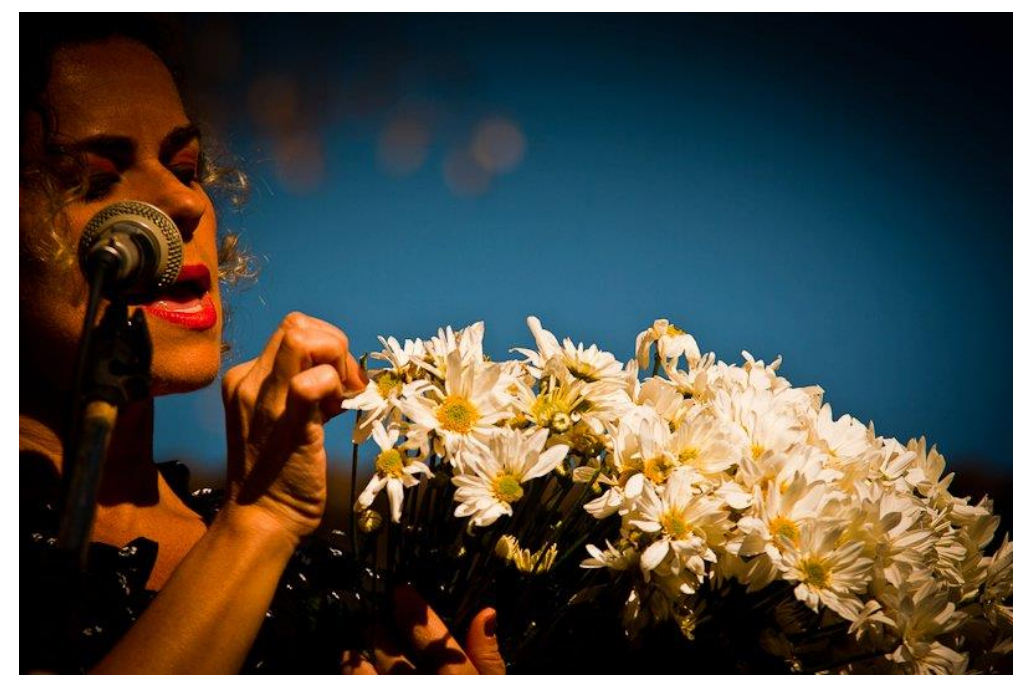

Fonte: Companhia Cênica Nau de Ícaros. Foto: Aldo Segnini. 
Os mesmos elementos utilizados habitualmente nos espetáculos tradicionais circenses, e que também foram identificados nos outros espetáculos da própria Companhia, são trapézios, cordas, tecidos, liras, cadeirinhas e equipamentos de alpinismo. Criam um diferencial, ou um olhar específico, que não está condicionado ao formato, e sim à maneira como esses elementos se relacionam com o movimento criado pelos atores-performers, aliado às temáticas, e outras materialidades da cena que surgiram no processo de criação.

Há também uma repetição de modos de residir na cena, relacionada à própria história das visualidades. A atuação em um espaço da cena que possui profundidade e altura é observada a partir do século XX, principalmente nas encenações que apresentavam uma cenografia tridimensional com traços arquitetônicos. As massas e volumes deram lugar aos modelos de ocupação de uma cena plana e com perspectivas artificiais. Os movimentos, gestos e olhares dos atores passaram a estruturar e dar vida aos espaços. Assim, as materialidades da cena surgem também de dentro dos signos e significados do texto, ou seja, de como são compreendidos nas suas subjetividades. Cores, dimensões, volumes e perspectivas subjetivas criam uma densidade que é traduzida pelo próprio movimento dos atores, relacionados a luzes, objetos e tecnologias.

Muitas vezes traduzido como teatro visual, em que o movimento se torna elemento teatral dominante, são principalmente as cenografias propostas por Edward Gordon Craig ${ }^{108} \mathrm{e}$ Adolphe Appia ${ }^{109}$, que inauguraram uma cena que apresentava uma construção tridimensional, que propunha uma dinâmica na qual os objetos apresentavam relações de movimento. Nasce uma cena mais expandida, na qual identificamos a matéria física, a performatividade e a presentividade do público como unidades que se replicam, assim como as materialidades dinâmicas nas temáticas de espetáculos da atualidade, como o Tirando os pés do chão.

\footnotetext{
${ }^{108}$ Edward Henry Gordon Craig (1872-1966) foi importante artista que, no início do século XX, desencadeou, através de suas produções teóricas e práticas, uma série de provocações e pensamentos acerca da cena total, de um conjunto de formas e volumes móveis no espaço da cena e da relação entre o movimento dos objetos no espaço físico e também no espaço abstrato da cena.

109 Adolphe Appia (1862-1928) foi arquiteto e encenador suíço, cujas teorias, especialmente no campo interpretativo da luz, ajudaram a concretizar as encenações simbolistas do século XX. Apontava a disparidade entre cenografias bidimensionais e a tridimensionalidade do ator como um problema a ser resolvido na concepção da cenografia. Para tanto, Appia desenhou cenografias que em sua simplicidade criavam um ambiente tridimensional e não mais um plano bidimensional, como ocorria na cenografia tradicional (Disponível em: <http://www.fap.pr.gov.br/arquivos/File/Arquivos2009/Pesquisa/Rev_cientifica4/artigo_Norton_Dudeque.pdf >. Acesso em: 20 nov. 2016).
} 
Edward Gordon Craig (1963, p. 18) identifica um fazer teatral cuja cenografia apresenta traços de dinamismo, quando expõe a respeito todos os estudos que sucederam as suas ideias. A cena e o movimento assumem o rompimento com o texto, mas sem excluí-lo e lhe dando a importância necessária. Propõe um olhar para as materialidades da cena como “efeitos de conjunto", em uma ampliação da importância de todos os aspectos de uma criação teatral, sem realmente dar maior valor a um aspecto ou outro, e sim equalizando as materialidades, a fim de ter uma obra de arte total.

Nesse ensejo de uma cena que possui um espaço e um tempo dilatados, encontramos nas artes do circo exatamente a característica inerente à arte total, em uma cenografia que acompanha a própria história do circo e a compreensão das diversas modalidades e artistas circenses. A composição de uma cena com profundidade e altura, essencial às artes do circo, é identificada na formação de uma cenografia dinâmica produzida pelos seus artistas múltiplos.

À semelhança dos estudos do começo do século XX, que originaram o que observamos hoje como espaço da cena, a utilização dos elementos aéreos do circo, na forma como a Companhia Cênica Nau de Ícaros desenha o espaço da cena, se dá por meio do movimento.

Mesmo o espetáculo tendo sido concebido para ser apresentado no teatro, numa relação frontal, os traços de uma cenografia em movimento são apresentados nas diferentes cenas e disposições espaciais.

Figura 64 - Disposição espacial das cadeiras no espetáculo Tirando os pés do chão

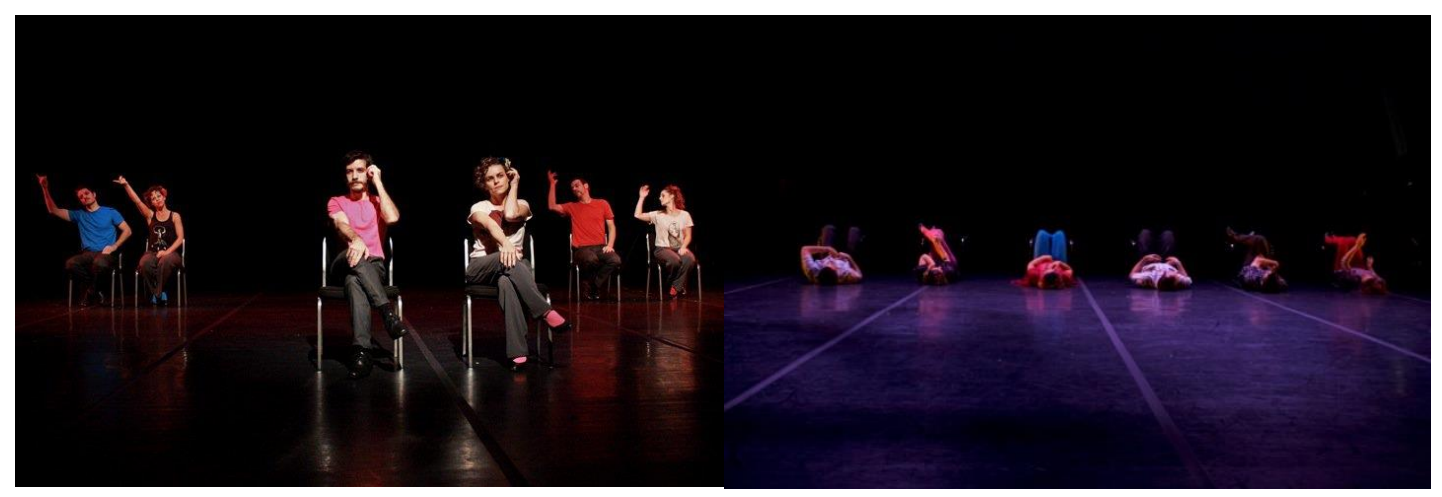

Fonte: Companhia Cênica Nau de Ícaros. Foto: Chris Von Ameln e Caio Castor.

Na cena inicial, a cenografia é composta de seis cadeiras, que remetem às entrevistas e ao consultório sentimental da primeira etapa do projeto, que são manuseadas e dispostas pelos 
atores-performers em diferentes formações espaciais ao longo do espetáculo. Ao mesmo tempo, as cadeiras são colocadas na lateral de dentro do palco, como se fosse a periferia da cena, ou uma plateia aproximada. Em algumas ocasiões, algumas pessoas do público foram chamadas para estarem em cena, não como atores-performers, mas como atoresobservadores, e ficavam sentados nas cadeiras na periferia da cena.

Em uma tela preta foram projetados vídeos elaborados e inspirados a partir das cartas de Nelson Rodrigues. A composição espacial da cena utilizando a iluminação e as imagens projetadas de vídeos já tinham sido muitas vezes utilizadas pela Companhia em outros espetáculos. Imagens pré-gravadas e imagens ao vivo foram experimentadas, assim como a forma de acionar essas mídias sofreram, ao longo das temporadas, algumas modificações. $\mathrm{Na}$ estreia as imagens foram acionadas pelo videomaker Felipe Sztutman através do seu celular, e em temporadas seguintes pelos atores-performers de dentro da mesa de som que foi colocada no palco, fazendo parte da cenografia.

A sonoplastia é executada também pelos próprios atores no palco, e a entrada e saída das músicas é deslocada da cabine técnica, que normalmente está invisível e fora do espaço da cena, para o palco, compondo a cena numa relação visível e real.

Figura 65 - Computador e mesa de som ao fundo da cena, disposta na lateral do palco

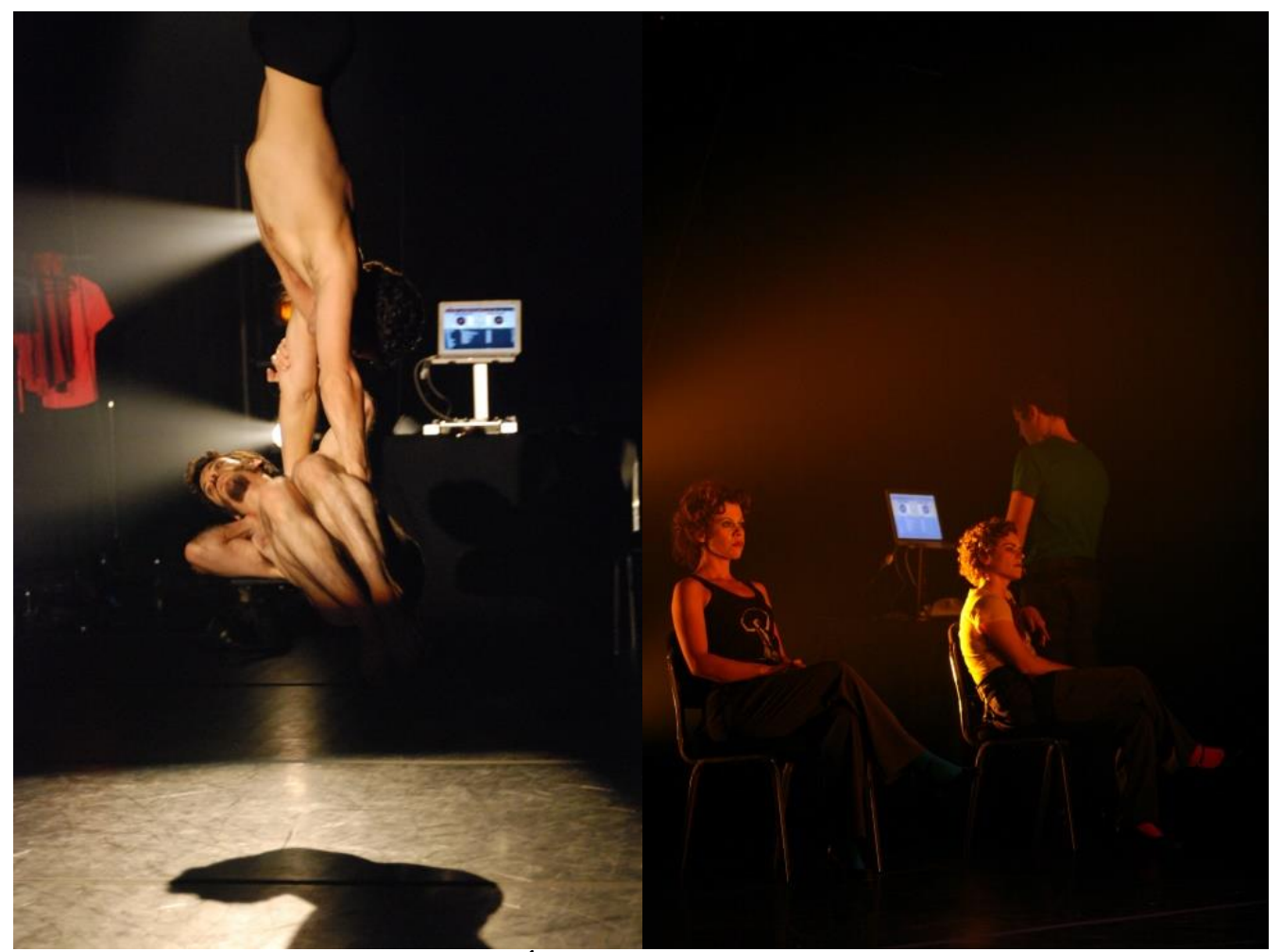

Fonte: Companhia Cênica Nau de Ícaros. Foto: Valéria Grzywacz e Henrique Lenza 
As tecnologias empregadas no espetáculo eram diversas, mas a intervenção do movimento de quem executava ou acionava as engenharias da cena era semelhante e sempre estava presente. Uma unificação das funções acontecia; técnicos se tornavam atoresperformers ao entrar na cena, e os próprios atores-performers se tornavam técnicos ao manusear cordas, acionar o som e vídeo, ou filmar a cena de dentro da cena.

Os elementos aéreos do circo também eram manipulados de forma distinta, ou seja, sofriam alterações e diversificavam o desenho projetado na cena durante o espetáculo. As contrarregragens eram reveladas pelos os atores-performers, que utilizavam equipamento de alpinismo (cordas, cadeirinhas, mosquetões, grigri, roldanas e fitas de ancoragem), enquanto os corpos de outros atores-performers realizavam manobras nos aparelhos aéreos, modificando a estrutura sólida da cenografia.

Figura 66 - Contrarregragem revelada durante cena do espetáculo Tirando os pés do chão

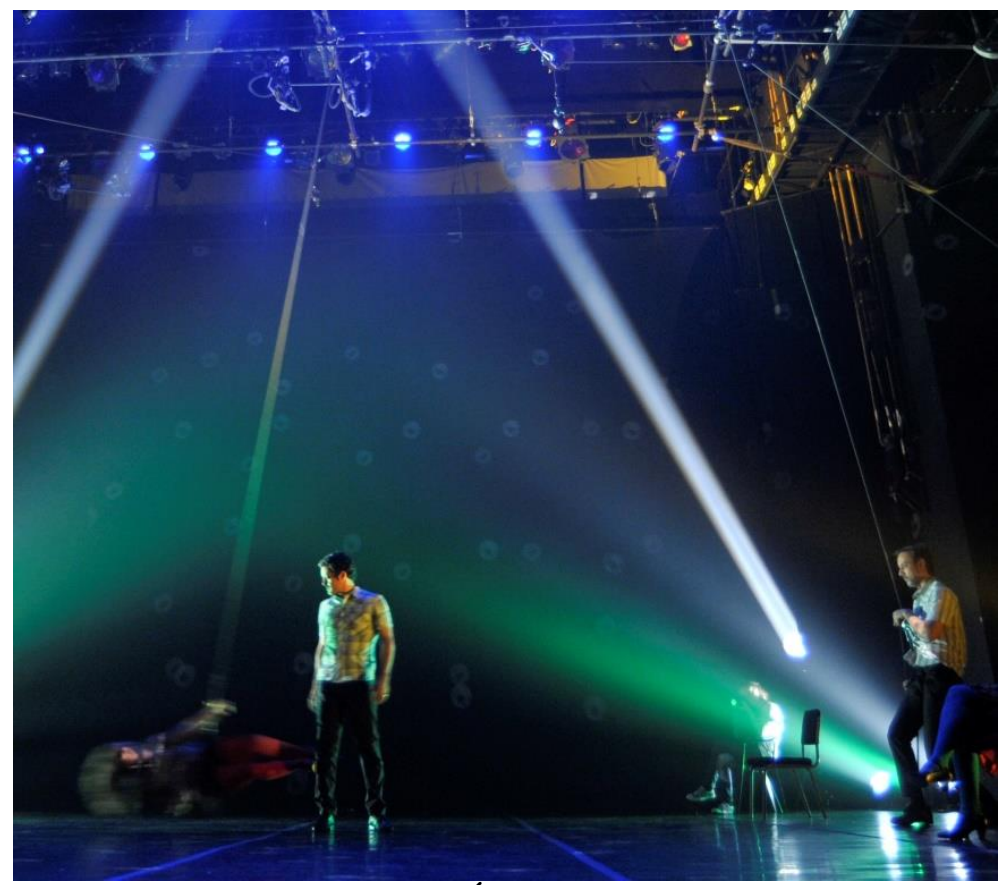

Fonte: Companhia Cênica Nau de Ícaros. Foto: Chris Von Ameln.

A contrarregragem como um conjunto de ações que fazem com que a engrenagem do palco funcione, no caso do circo, está relacionada diretamente com a segurança e a manipulação dos equipamentos aéreos. Normalmente é executada de fora da cena nos circos e circos-teatros tradicionais por um profissional subordinado diretamente ao diretor-ensaiador. Com funções múltiplas, os contrarregras executam ações nos bastidores, da forma mais discreta possível. 
Nos espetáculos da Companhia Cênica Nau de Ícaros a função dos contrarregras sempre é executada por um dos atores-performers dentro da cena, compondo o espaço através dos movimentos revelados ao público. As atribuições de suspender, colocar e tirar equipamentos aéreos, bem como de dar os sinais, informando à equipe os tempos preparatórios para o início das ações, são somadas à cena, tornando-se materialidades, corporificando as cenografias antes veladas, e compondo também desenhos no espaço.

Em outra cena específica, que traduzia as perdas referentes ao amor, as materialidades foram elaboradas a partir de uma entrevista específica só com os atores-intérpretes. Os trapézios foram utilizados de maneira frontal e a tridimensionalidade da cena foi gerada através da interposição dos movimentos dos atores-performers nos elementos aéreos. Os apoios dos corpos suspensos e as relações de portagem circense, aliados à iluminação, geravam mobilidade para a cenografia circense.

Os três trapézios dispostos em planos espaciais distintos revelavam uma cenografia circense tradicional, ordenada no espaço de forma diferente. A iluminação recortada propunha uma visão parcial e focada dos corpos dos atores, gerando uma aproximação com conceitos de Appia (VIANA, 2010, p. 275) ${ }^{110}$, tanto no que diz respeito aos planos de ação, cujas origens são gregas, como na utilização da iluminação como recorte e ambientação da cena.

Figura 67 - Cenas utilizando trapézios no espetáculo Tirando os pés do chão

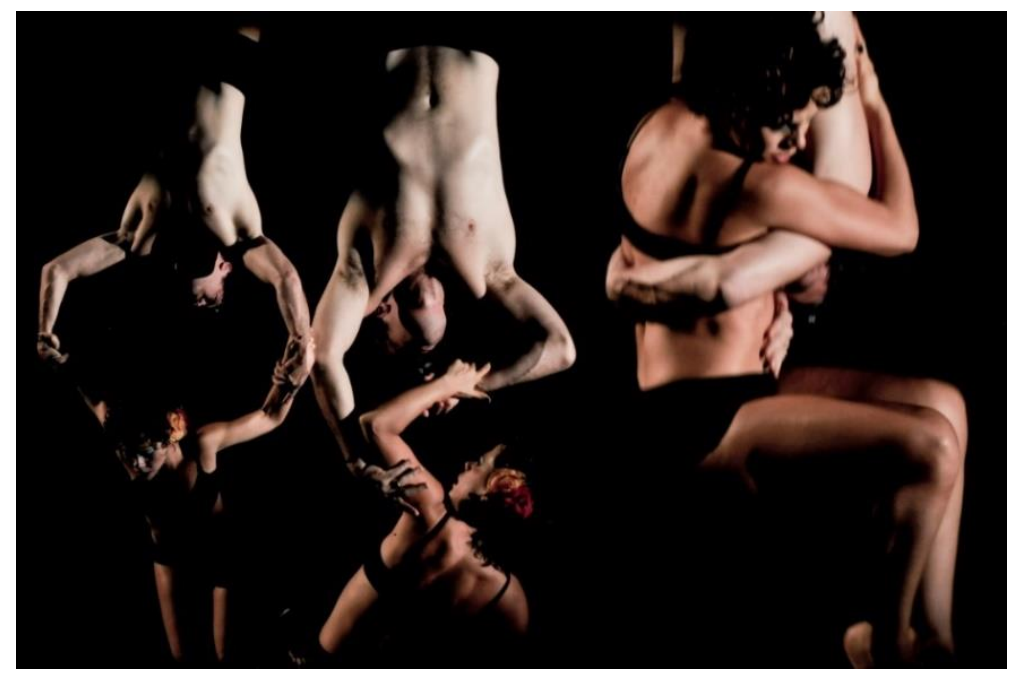

\footnotetext{
${ }^{110}$ Descrição do cenário de Appia e Dalcroze, para Orfeu e Eurídice.
} 

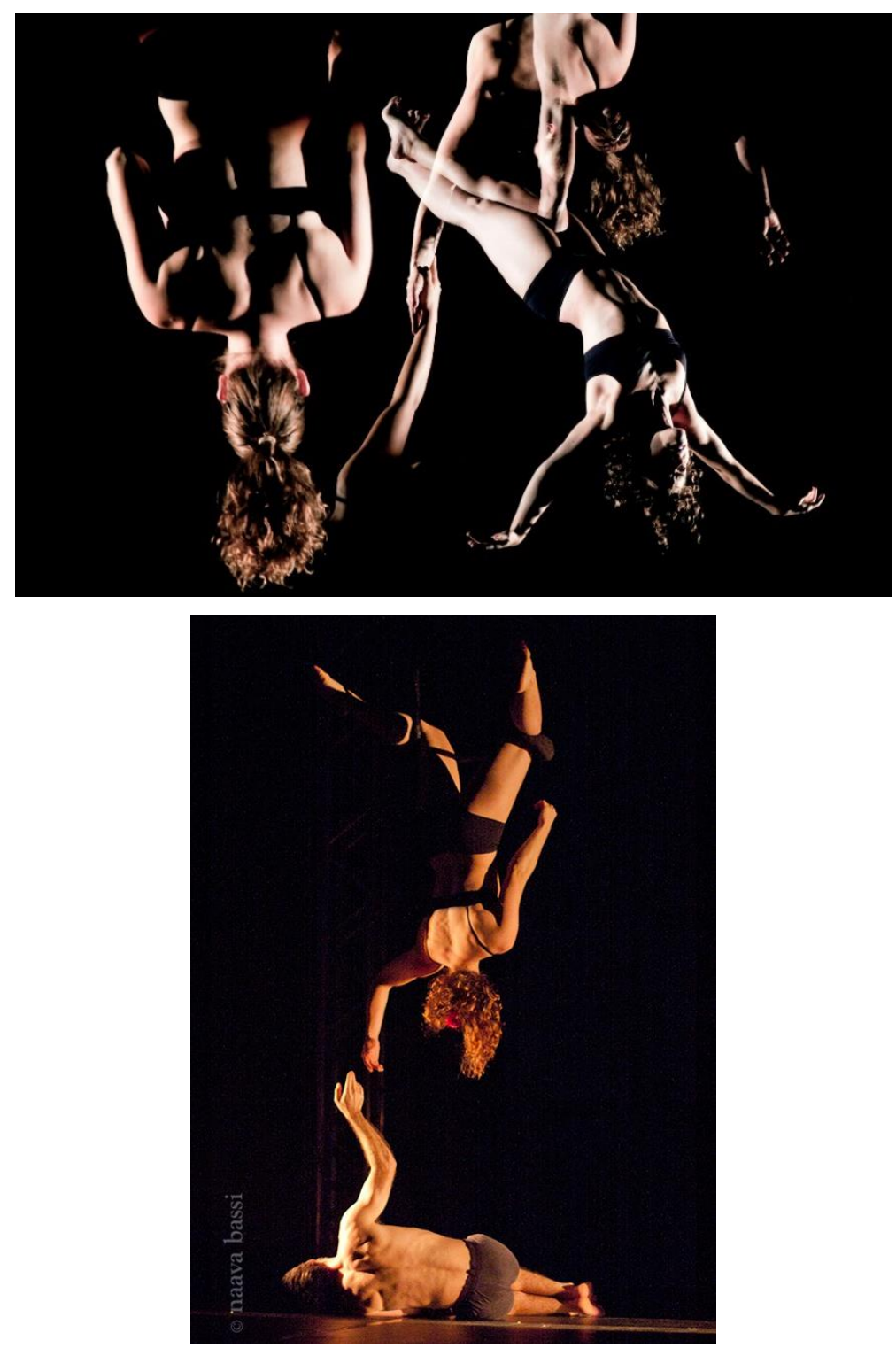

Fonte: Companhia Cênica Nau de Ícaros. Fotos: Chris Von Ameln e Naava Bassi.

Os três planos de ação, superiores, terreno e das profundezas, cuja origem está presente no teatro grego, são representados pelos trapézios e pela movimentação dos atores na cena. A cena é composta por dois atores em cada trapézio, um ator realizando o papel de portô e outro de volante. Um dos trapézios propõe a suspensão fora do chão (plano superior); outro, pequenas elevações com apoios sutis no chão (plano terreno); e o terceiro, um contato direto com o chão (plano das profundezas). A incidência da luz parcial e focada nos volantes revela e desvenda não só os movimentos, como a cenografia da cena.

Na cena final, uma lira é utilizada de duas formas: primeiramente como aparelho para um número aéreo, no qual o ator-performer se movimenta no espaço aéreo da cena; e, posteriormente, como elemento sozinho na cena, representando no ar um círculo que gira no 
eixo e remete à imagem de uma aliança. Em ambos os casos, o aparelho circense possui funções cenográficas que são diferenciadas pela presença ou não do corpo e pelos movimentos, mas tanto uma imagem como outra é produtora de presença e tem significado cultural.

Figura 68 - Cena utilizando lira no espetáculo Tirando os pés do chão

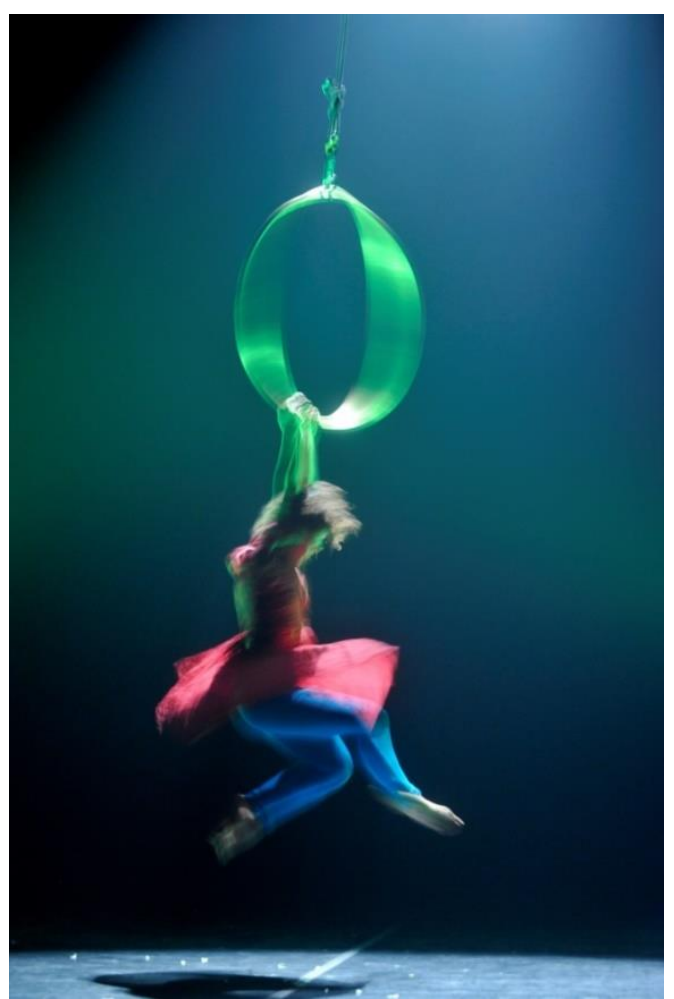

Fonte: Companhia Cênica Nau de Ícaros. Foto: Chris Von Ameln.

A disposição da cenografia proposta durante todo o projeto Tirando os pés do chão exemplifica e confirma o que poderia ser uma cenografia em movimento. O processo e o espaço compartilhado através do movimento colocam os observadores numa relação de condução, ao mesmo tempo que a tridimensionalidade do espaço é ampliada pelos elementos aéreos do circo. O movimento da cena nunca está dissociado da cenografia, um interfere no outro, produzindo a sensação de unidade. Os corpos móveis e massas das materialidades são produtoras de um movimento cenográfico e de uma cena total, na qual todos os aspectos da produção dialogam e chegam ao espectador como algo único, ao mesmo tempo material e produtor de imaginação. 


\subsubsection{O que te tira os pés do chão?}

Ao analisar este projeto, foi observada que a fusão entre as formas de conteúdo e as formas de expressão se deu quando as pessoas, que estavam presentes em diversas etapas do projeto, pararam para pensar se suas escolhas de hoje são ou não permeadas pelo amor, por meio de signos ou estruturas significantes criadas pelos atores-performers, pelo público entrevistado e pela equipe de criação do espetáculo.

O resgate de sentimentos básicos do ser humano, apresentado como tema, também poderia ser uma necessidade da sociedade contemporânea, repleta de imagens e informações, inserida em uma cultura multifocada e virtual, na qual as experiências e a presença física são cada vez mais restritas.

Neste projeto é perceptível um impulso de captura de uma realidade mediante a inclusão do público junto ao processo de criação. É observado um desejo da Companhia de levar o espectador a se confrontar com o amor no seu estado bruto, retratado pelos estados de suspensão experimentados e observados, que envolvem o participante em um imaginário próprio, pessoal e social. Trata-se de um diálogo entre artista e indivíduo participante incondicional de uma "hiper-ramificada" rede de comunicação, que representa a sociedade atual. E é por meio de um sentimento inerente ao ser humano, o amor, que o espectador, habituado a fragmentos, é provocado a elaborar leituras do seu viver surpreendentes e referentes a experiências e sentimentos próprios.

Pessoas, rostos, estórias e gestos, que claramente foram tocados pelas perguntas elaboradas, e que motivaram a elaboração do espetáculo e da "ação performática", se explicitam em gestos e imagens cênicas. Podemos aqui falar de uma cenografia em movimento que surge da comunicação no espaço da cena, nas suspensões e numa proximidade real de intensidades variadas, conforme o envolvimento de cada pessoa no projeto. Ao mesmo tempo, esses personagens reais e urbanos se misturam ao universo das cartas e personagens de Nelson Rodrigues, que no livro traduz de forma cômica e bastante vertical esse universo presente em todos nós.

O grande feito do Tirando os pés do chão foi a presença de um material que não foi extraído exclusivamente de experiência dos intérpretes-criadores, e sim do diálogo das sensações e histórias destes atores-performers com as sensações e histórias de outras pessoas. Representou um "sair do seu universo gestual e caminhar no do outro". Trouxe outros gestos, 
outras maneiras de se movimentar, de pensar a suspensão como uma temática e uma sensação, e não só como uma ação ou representação estética. Foi um processo menos centralizador, no sentido das experiências dos próprios atores não serem as únicas fontes de inspiração, e do público ter a capacidade de ler com mais facilidade os seus próprios gestos.

Tirando os pés do chão apresenta uma maneira peculiar de abordar o amor, assim como toda a obra de Nelson Rodrigues, sob uma forma na qual os próprios personagens (público) se tornam coautores, revelando suas próprias estórias. O amor apresentado de forma real e concreta é ao mesmo tempo diluído na poesia e suspensão dos corpos no espaço da cena.

Histórias são contadas através de movimentos e cenografias visíveis e invisíveis. O público faz parte do processo e é inserido dentro do universo e espaço propostos, como se fizesse parte dessa família circense. É convidado a voar, como se por um breve momento pudesse sentir a suspensão do amor, a sensação de tirar os pés do chão.

Você deseja saber quem é Myrna e fará a si mesma perguntas como esta: É loura? Morena? Nasceu no Cairo? Em Alexandria? Adivinha o futuro? É velha ou moça? Respondo: Myrna sou eu. Entretanto, não é Myrna que está em causa. Quem está em causa é você! Sim, Leitora que nunca vi, bela, feia, juvenil ou passada. Você sofre e basta. E é para você própria que devem voltar suas atenções. Examine o seu caso e mais do que isso: examine seu coração. Você tem um amor infeliz. Infeliz por quê? De quem é a culpa? Dele ou sua? Ou será da própria vida, cega, obtusa, implacável? São perguntas que você faz a si mesma e aos outros, sem lhes achar resposta. Longe do bem-amado você é infeliz; perto também. Na sua ausência, tem saudades; na presença sofre por outros motivos. Se ele é fiel você chora, considerando a hipótese da infidelidade. Ora, as hipóteses também contam em amor. Nós pensamos assim: Ele é fiel hoje; será amanhã? Basta esta possibilidade - tênue, remota, teórica possibilidade - para que cada uma de nós sofra na carne e na alma. Também sofremos por tudo que talvez aconteça, por tudo que talvez não aconteça. Haverá remédio para isso? É o que você pergunta a si mesma. Eu, Myrna, poderia responder, lacônica e definitiva: Não! Não se pode amar e ser feliz ao mesmo tempo. Seja qual for seu drama, escreva para - Myrna - Redação do Diário da Noite. Dê seu primeiro nome e o primeiro nome do seu namorado, noivo ou marido. A data de nascimento de ambos. E conte seu romance. Eu lhe direi a verdade, só a verdade, presente e futura. E se quiser saber quem é Myrna, responderei: Apenas uma mulher! $!^{11}$

\footnotetext{
${ }^{111}$ Texto final do espetáculo Tirando os pés do chão, inspirado no primeiro texto do livro Não se pode Amar e ser feliz ao mesmo tempo (cedido pela Companhia Cênica Nau de Ícaros).
} 


\section{CONCLUSÃO}

Após percorrer este caminho que se apresentou como o lugar do aqui você pode falar sobre o amor, um espaço do aqui você pode voar foi aberto. Na possibilidade de expressar e dançar o narrado, o sentimento universal do amor pôde ser descrito e revelado através de formas dinâmicas inscritas na cena.

Estudar o espaço da cena sob a ótica dos elementos aéreos do circo possibilitou apontar o movimento dinâmico e as materialidades que as artes do circo produzem através de desenhos ousados.

Evidenciar um espaço que está em constante mudança só foi possível pelo compartilhamento de informações, tanto no que se refere à pesquisa bibliográfica da história das suspensões no circo, como no destaque dos caminhos trilhados pela Companhia Cênica Nau de Ícaros e, consequentemente, pela minha própria história. Compartilhar um processo de criação, seja por meio das ações de um grupo de artistas cênicos, seja pela elaboração de uma pesquisa sobre o universo circense, permitiu criar um cruzamento de um espaço universal com um pessoal.

Os percursos elucidados na pesquisa sobre como as suspensões surgiram no universo das artes do circo promoveram mais que um respirar o tema: trilhou-se uma passagem para descobertas que compreendem o porquê do encantamento na ação de voar. As pequenas elevações que eram apresentadas nas formas mais simples de tirar os pés do chão, descritas nos primórdios das artes do circo, se desenvolveram em grandes voos cênicos.

Os aparatos tecnológicos criados com tamanha precisão e dimensões gigantescas ao longo da história do circo são somados ao espaço da cena no mesmo grau de importância que as pequenas e sutis ações, e ambos aproximam o público do espetáculo cênico. A retina de quem observa tanto os grandes voos quanto as pequenas sutilezas suspensas, quando tocada, se assemelha a sussurros no pé de ouvido, permitindo às pessoas subjetivamente tirarem os pés do chão.

Observou-se uma multiplicidade de investigações que reelaboraram e recuperaram espaços e modos de fazer descritos na história das suspensões no circo. As artes do circo invadiram teatros, ruas, fachadas de prédios e tantos outros lugares, deflagrando uma nova forma de ocupar o espaço da cena, cuja popularidade é inerente a esse modo de habitar a cena. 
A ampliação das possibilidades e espacialidades da cena se apresentou como característica marcante.

A delicadeza almejada e os assuntos abordados, seja no espaço da cena, seja no espaço subjetivo criado nesta pesquisa, fazem parte de uma sucessão de acontecimentos que criaram símbolos e signos ao longo da história das artes do circo, e da história das artes cênicas na cidade de São Paulo. Desvendar os caminhos de um grupo de jovens artistas que surgiu em 1992, que estavam ao mesmo tempo no Circo Escola Picadeiro, mais que um prazer, foi uma forma de manifestar estados amorosos que caminham paralelos às artes cênicas, em um mesmo espaço, que é a cena.

No desenvolvimento da pesquisa, estabelecendo o foco na cidade de São Paulo, o processo de criação compartilhado, exemplificado pelo projeto Tirando os pés do chão da Companhia Cênica Nau de Ícaros, ilustrou a criação de um amálgama de materialidades. Aproximar o público e inseri-lo na cena, fugindo de desenhos e exposições habituais, foi observado, aliado ao objetivo da Companhia de apresentar os gestos e imagens doados pelos observadores participantes.

A elucidação da própria história da Companhia se fez necessária para entender um processo de construção de uma forma de habitar o espaço da cena que ultrapassa os limites da Companhia e se estende a uma geração de artistas que hoje têm uma maturidade cênica que se relaciona diretamente com um espaço em movimento.

$\mathrm{Eu}$, como intérprete-criadora e pesquisadora, atravessei fisicamente o lugar do conhecido e do desconhecido, desvendei espaços que fazem parte de uma história muito maior que a minha, e pensamentos intrépidos surgiram. Escrever sobre o que já foi vivido é um risco tão grande quanto projetar-se em queda em um tecido a doze metros de altura, ou dançar em um trapézio em um balão de ar quente a vinte metros do chão.

Os desenhos da cena rabiscados pelas matérias efêmeras e transitórias só são possíveis porque existem as cenografias, os corpos, os movimentos, ou seja, um espaço em movimento. O deslocamento físico e onírico é traçado, inventado e reinventado por todas as pessoas que estabeleceram e estabelecem relações espetaculares, pelos observadores e observados que criam teatralidade nas suas ações.

Estar fora dos limites habituais no espaço faz parte do universo em que as suspensões conduzem a cena. Transcender pensamentos através da ação de voar possibilita aos 
acontecimentos cênicos e suspensos ultrapassarem o espaço físico da cena. E a ação de desafiar a gravidade cria materialidades suspensas e cenografias em movimento.

Observamos também a subjetividade do espaço da cena, que pode ser traduzida pela diversidade dos desenhos invisíveis traçados pelos corpos, em relação direta com as cenografias e elementos aéreos do circo. Esses desenhos permitem que os conteúdos e formas da imaginação do pensamento humano sejam comunicados e expostos no espaço da cena.

Arriscamos falar sobre esse lugar transitório, esse espaço em movimento subjetivo e objetivo; que é composto pelas ações e expressões presentes nas materialidades da cena, que são os conteúdos e as formas que se manifestam nesse espaço.

A presença do corpo exemplificado na pesquisa e a existência objetiva de um espaço em movimento foram ilustradas pelas variáveis obtidas nesses lugares e pela sua relação com a gravidade. O corpo, ao enfrentar a gravidade, produz linhas verticais, horizontais e diagonais no espaço da cena. Esses desenhos rabiscados através de linhas invisíveis são destacados quando o elemento aéreo dilata a existência de um jogo entre a verticalidade e a gravidade, entre o fantástico e o real, entre o tangível e o etéreo.

No circo tudo se mistura, pontos estáticos e pontos móveis, corpos em movimento e cenografias fotográficas. Nos espaços em movimento, em que o circo pincela suas cores, as cenografias não estão mais estáticas, os corpos não têm limites e o espaço pode ser visível ou intangível. Nos acontecimentos espetaculares em que a suspensão física suspende a cena, o que importa é a sensação, é o desprendimento das ações finitas, é a elevação do olhar, é a possibilidade de voar fisicamente e também através da imaginação. 


\section{REFERÊNCIAS}

ABREU, Kil. Experimentação e realidade: grupos e modos de criação teatral no Brasil. In: SAADI, Fátima; GARCIA, Silvana (Orgs.). Próximo ato: questões da teatralidade contemporânea. São Paulo: Itaú Cultural, 2008. p. 91-95.

ANDRADE, Carlos Drummond de. Alguma poesia. Rio de Janeiro: Record, 2001.

. Seleta em prosa e verso. Estudo e notas de Gilberto Mendonça Teles. 6. ed. Rio de Janeiro: Record, 1985.

ANDRADE, José Carlos Santos. O espaço cênico circense. 2006. Dissertação (Mestrado em Artes Cênicas) - Escola de Comunicações e Artes da Universidade de São Paulo (ECA/USP), São Paulo, 2006.

O teatro no circo brasileiro: estudo de caso: circo-teatro Pavilhão Arethuzza. 2010. 452 p. Tese (Doutorado em Artes Cênicas) - Escola de Comunicações e Artes da Universidade de São Paulo (ECA/USP), São Paulo, 2010.

ANDRADE, Mário de. Danças dramáticas no Brasil. Belo Horizonte: Itatiaia, 1982. v. 1.

ARISTÓTELES. Poética. Tradução, prefácio e notas de Eudoro de Souza. Porto Alegre: Globo, 1966.

BOLOGNESI, Mário Fernando. Palhaços. São Paulo: Editora UNESP, 2003.

BORTOLETO, Marco Antonio Coelho; CALÇA, Daniela Helena. O tecido circense: fundamentos para uma pedagogia das atividades circenses aéreas. Conexões, Campinas, SP, v. 5, n. 2, p. 73-89, dez. 2007a. Disponível em: <http://periodicos.sbu.unicamp.br/ojs/index.php/conexoes/article/view/8637880>. Acesso em: 18 out. 2016.

BORTOLETO, Marco Antonio Coelho; CALÇA, Daniela Helena. O trapézio circense: um estudo das diferentes modalidades. EFDeportes.com, Buenos Aires, año 12, n. 109, junio 2007b. Disponível em: <http://www.efdeportes.com/efd109/o-trapezio-circense.htm>. Acesso em: 18 out. 2016.

BOUDREAULT, Françoise. Acrobatie aérienne et théâtralité. L'Annuaire Théâtral: revue québécoise d'études théâtrales, n. 32, p. 75-92, 2002. Disponível em: <https://www.erudit.org/revue/annuaire/2002/v/n32/041506ar.pdf>. Acesso em: 18 out. 2016.

BROOK, Peter. A porta aberta: reflexões sobre a interpretação e o teatro. Tradução de Antonio Mercado. 6. ed. Rio de Janeiro: Civilização Brasileira, 2010. 1970.

O teatro e seu espaço. Tradução de Oscar Araripe e Tessy Calado. Petrópolis: Vozes, 
BUENO, Luciana. Muito além da caixa cênica: a realização cenográfica contemporânea na cidade de São Paulo. 2007. 231 p. Dissertação (Mestrado em Artes Cênicas) - Escola de Comunicações e Artes da Universidade de São Paulo (ECA/USP), São Paulo, 2007.

BULFINCH, Thomas. O livro de ouro da mitologia (a idade da fábula): história de deuses e heróis. Tradução de David Jardim Júnior. 7. ed. Rio de Janeiro: Ediouro, 1999.

CANCLINI, Néstor Garcia. Culturas híbridas: estratégias para entrar e sair da modernidade. Tradução de Ana Regina Lessa, Heloísa Pezza Cintrão; tradução da introdução Gênese Andrade. 4. ed. São Paulo: Edusp, 2008. (Ensaios Latino-americanos, 1).

CARLSON, Marvin. Teorias do teatro: estudo histórico-crítico, dos gregos à atualidade. Tradução de Gilson Cesar Cardoso de Souza. São Paulo: Editora da UNESP, 1997.

CASTRO, Alice Viveiros de. O elogio da bobagem: palhaços do Brasil e o mundo. Rio de Janeiro: Família Bastos, 2005.

CAVENDISH, Richard. The first flying trapeze is performed. Disponível em: $<$ http://www.historytoday.com/richard-cavendish/first-flying-trapeze-performed>. Acesso em: 02 out. 2016.

CENTRE NATIONAL DES ARTES DU CIRQUE (CNAC). Pascal Jacob. Disponível em: <http://www.cnac.fr/cnac-603-Collection_Quel_cirque_Les_Nouveaux_Nez-Pascal_Jacob>. Acesso em: 15 ago. 2013.

COHEN, Miriam Aby. Cenografia Brasileira século XXI: diálogos possíveis entre a prática e o ensino. 2007. 198 p. Dissertação (Mestrado - Artes Cênicas) - Escola de Comunicações e Artes da Universidade de São Paulo (ECA/USP), São Paulo, 2007.

COHEN, Renato. Performance como linguagem: criação de um tempo-espaço de experimentação. 2. ed. São Paulo: Perspectiva; Editora da Universidade de São Paulo, 2009. (Debates, 219).

COIMBRA, Ana Luisa de Castro et al. O Movimento Armorial reafirmando as raizes da cultura popular: resumo. Trabalho apresentado ao GT de Produção Editorial e Cultural, do IX Congresso Brasileiro de Ciências da Comunicação da Região Nordeste, promovido pela Intercon e UFBA, em Salvador, BA, em 2007. Disponível em: <http://www.intercom.org.br/papers/regionais/nordeste2007/resumos/R0259-1.pdf>. Acesso em: 20 out. 2016.

CORTINA, Arnaldo. A paixão do ciúme: análise semiótica do discurso. Alfa: Revista de Linguística, Enunciação e Figuratividade, São Paulo, Editora UNESP, v. 48, n. 2, p. 79-94, 2004. Disponível em: <http://repositorio.unesp.br/bitstream/handle/11449/107799/ISSN19815794-2004-48-2-79-94.pdf?sequence=1>. Acesso em: 20 nov. 2016.

COSTA, Eliene Benício Amâncio. Saltimbancos urbanos: a influência do circo na renovação do teatro brasileiro nas décadas de 80 e 90. 1999. 2 v. Tese (Doutorado) - Escola de Comunicações e Artes da Universidade de São Paulo (ECA/USP), São Paulo, 1999.

CRAIG, Edward Gordon. Da arte do teatro. Lisboa: Arcádia, 1963. 
DUARTE, Regina Horta. Noites circenses: espetáculos de circo e teatro em Minas Gerais no século XIX. Campinas, SP: Editora da Unicamp, 1995.

DUMONT, Agathe. Verticalité, pesanteur et gravité: réflexions autour de ces notions dans l'enseignement professionnel des arts du cirque: trapèze fixe, mât chinois, corde et tissu: manuel pédagogique. Bruxelles: Fédération Européenne des Écoles de Cirque Professionnelles (FEDEC), 2015. Disponível em: $<$ http://www.ffec.asso.fr/download.php?file=1ffec/intents/intentsmanuelverticalite10final.pdf>. Acesso em: 10 out. 2016.

FÉRAL, Josette. Por uma poética da performatividade: o teatro performativo. Tradução de Lígia Borges. Sala Preta: Revista do Departamento de Artes Cênicas, São Paulo, ECA/USP, n. 8, p. 197-210, 2008.

Performance and theatricality: the subject demystified. Modern Drama, v. 25, p. 170181, mar. 1982.

. Theatricality: the specificity of theatrical language. Translated by Ronald P. Bermingham. SubStance, University of Wisconsin Press, v. 31, No. 2/3, Issue 98/99, Special Issue: Theatricality, p. 94-108, 2002. Disponível em: 〈http://www.jstor.org/stable/3685480>. Acesso em: 20 nov. 2016.

La théâtralité: recherche sur la spécificité de la langage théâtral. Poétique, Paris, n. 75, p. 347-361, sept. 1988.

FERNANDES, Sílvia. Grupos teatrais: percurso e linguagem. 1987. 3 v. Dissertação (Mestrado) - Escola de Comunicações e Artes da Universidade de São Paulo (ECA/USP), São Paulo, 1987. v. 2.

Teatralidades contemporâneas. São Paulo: Perspectiva, 2010.

Teatralidade e performatividade na cena contemporânea. Repertório, Salvador, n. 16, p. 11-23, 2011.

FRANCO JÚNIOR, Hilário. Cocanha: várias faces de uma utopia. São Paulo: Ateliê Editorial, 1998.

GLUSBERG, Jorge. A arte da performance. São Paulo: Perspectiva, 1987.

GUINSBURG, Jacó. Da cena em cena: ensaios de estética e história do teatro. São Paulo: Perspectiva, 2001. (Estudos, 175).

GUMBRECHT, Hans Ulrich. Produção de presença: o que o sentido não consegue transmitir. Rio de Janeiro: Contraponto; PUC-Rio, 2010.

GUY, Jean-Michel. (Dir). Avant-garde, Cirque!: les arts de la piste en révolution. Paris: Autrement, 2001. (Collections Mutations, 209). 
GUY, Jean-Michel; Rosemberg, Julien. Le nuancier du cirque. 2010. [Paris]: Scérén; Centre National de Documentation Pédagogique (CNDP); Centre National des Arts du Cirque (CNAC); Association Hors Les Murs, 2010. DVD.

GUZZO, Marina Souza Lobo. Risco como estética, corpo como espetáculo. São Paulo: Annablume; Fapesp, 2009.

HOTIER, Hugues. Cirque, communication, culture. Talence, France: Presses Universitaires de Bordeaux, 1995.

JACOB, Pascal. Le cirque: un art à la croisée des chemins. Paris: Gallimard, 2001. (Découvertes Gallimard. Culture et société, 134).

JANDO, Dominique. Short history of the circus. Disponível em: <http://www.circopedia.org/SHORT_HISTORY_OF_THE_CIRCUS>. Acesso em: 30 set. 2016.

LEHMANN, Hans-Thies. Teatro pós-dramático. Tradução Pedro Süssekind. São Paulo: Cosac Naify, 2007.

LOUPPE, Laurence. Corpos híbridos. In: SOTER, Silvia; PEREIRA, Roberto (Orgs.). Lições de dança 2. Rio de Janeiro: UniverCidade, 2000. p. 27-40.

MAGALDI, Sábato. O texto no teatro. 3. ed., reimpr. São Paulo: Perspectiva, 2008. (Estudos, 111)

MATHEUS, Rodrigo Inácio Corbisier. As produções circenses dos ex-alunos das escolas de circo de São Paulo, na década de 1980 e a constituição do Circo Mínimo. Dissertação (Mestrado) - Instituto de Artes da Universidade Estadual Paulista "Júlio de Mesquita Neto", São Paulo. 2016. p. 214.

MEDEIROS, Maria Beatriz de (Org.). Arte e tecnologia na cultura contemporânea. Brasília: UnB; Dupligráfica, 2002.

MOSTAÇO, Edélcio (Org.). Sobre performatividade. Florianópolis, SC: Letras Contemporâneas, 2009.

MUCCI, Isabella. Circo Zanni e Linhas Aéreas: expressões da arte circense na cena contemporânea paulista. 2013. 233 f. Dissertação (Mestrado) - Instituto de Artes da Universidade Estadual Paulista "Júlio de Mesquita Neto”, São Paulo, 2013.

NOEL, Daniel (Ed.). The circus: 1870-1950. Los Angeles, CA: Taschen, 2008.

PAVIS, Patrice. Análise dos espetáculos: teatro, mímica, dança-teatro, cinema. Tradução de Sérgio Sálvia Coelho. 2. ed., reimpr. São Paulo: Perspectiva, 2010. (Estudos, 196).

A encenação contemporânea: origens, tendências, perspectivas. Tradução de Nanci Fernandes. São Paulo: Perspectiva, 2010. (Estudos, 490). 
PAVIS, Patrice. Le théâtre au croisement des cultures. Paris: Librairie José Corti, 1990.

. Vers une théorie de la pratique théâtrale: voix et images de la scène. 3e. éd. rev. et augm. Villeneuve d'Ascq (Nord): Presses Universitaires de Septentrion, 2000.

PRADO, Décio de Almeida. O teatro brasileiro moderno. 3. ed., 2. reimpr. São Paulo: Perspectiva, 2009.

RABANEL. Théâtrologie: le théâtre réinventé. Paris: L'Harmattan, 2003. v. 1.

REIS, Luiz Felipe. Espetáculo 'La verità' usa painel de Dalí como inspiração para unir elementos de circo, teatro e dança. O Globo Cultura, 29 jun. 2013. Disponível em: $<$ http://oglobo.globo.com/cultura/espetaculo-la-verita-usa-painel-de-dali-como-inspiracaopara-unir-elementos-de-circo-teatro-danca-8849144\#ixzz2daBv2ExF>. Acesso em: 20 ago. 2013.

RENGEL, Lenira. Dicionário Laban. São Paulo: Annablume, 2003.

RODRIGUES, Nelson (sob o pseudônimo de Myrna). Não se pode amar e ser feliz ao mesmo tempo. São Paulo: Companhia das Letras, 2002.

ROSEMBERG, Julien. Arts du cirque: esthétiques et évaluation. Paris: L'Harmattan, 2004.

ROUBINE, Jean-Jacques. A linguagem da encenação teatral 1880-1980. Rio de Janeiro; Zahar, 1992.

RYNGAERT, Jean-Pierre. Introdução à análise do teatro. Tradução Paulo Neves. São Paulo: Martins Fontes, 1996.

Ler o teatro contemporâneo. Tradução de Andréa Stahel M. da Silva. São Paulo: Martins Fontes, 1998. (Leitura e Crítica).

SCHIOCCHET, Michele Louise. Site-specific art?: reflexões a respeito da performance em espaços não tradicionalmente dedicados a esta. Urdimento, Dossiê Temático, v. 2, n. 17, p. 133, 2011.

SERVIÇO SOCIAL DA INDÚSTRIA (SÃO PAULO). Menor que o mundo: Nau de Ícaros. São Paulo: SESI-SP, 2012.

SILVA, Erminia. $O$ circo: sua arte e seus saberes: o circo no Brasil no final do século XIX a meados do XX. 1996. 162 f. Dissertação (Mestrado) - Instituto de Filosofia e Ciências Humanas, Universidade Estadual de Campinas, Campinas, SP, 1996.

Circo-teatro: Benjamim de Oliveira e a teatralidade circense no Brasil. São Paulo: Altana, 2007.

SILVA, Erminia; ABREU, Luís Alberto de. Respeitável público... o circo em cena. Rio de Janeiro: Funarte, 2009. 
SILVA, Fernando Wagner Serpa Vieira da. Um sistema de animação baseado em movimento capturado. 1998. 101 f. Dissertação (Mestrado) - Laboratório de Computação Gráfica COPPE/Sistemas, Universidade Federal do Rio de Janeiro (UFRJ), 1998. p. 4. Disponível em: <http://www.visgraf.impa.br/Projects/mcapture/publ/thesis-letter.pdf >. Acesso em: 20 jan. 2016.

SNIZEK, Andréa Bergallo. Corpo-comunicação: a poético do gesto. Contemporânea, Edição 20, v. $10, \quad$ n. $2, \quad$ p. 165-173, 2012. Disponível em: <http://www.contemporanea.uerj.br/pdf/ed_20/contemporanea_n20_11_BERGALLO.pdf>. Acesso em: 30 nov. 2016.

STANISLAVSKI, Konstantin. A criação de um papel. Prefácio de Robert Lewis; tradução de Pontes de Paula Lima. 14. ed. Rio de Janeiro: Civilização Brasileira, 2010.

TAIT, Peta. Circus bodies: cultural identity in aerial performance. New York: Routledge, 2005.

TEOTÔNIO SOBRINHO, José. $O$ ator no teatro de imagens. 2004. 146 p. Dissertação (Mestrado) - Escola de Comunicações e Artes da Universidade de São Paulo (ECA/USP), São Paulo, 2004.

TORRES, Antônio. O circo no Brasil. Rio de Janeiro: Funarte; São Paulo: Atração. 1998.

TUCCARO, Arcangelo. Trois dialogues de l'exercice de sauter, et voltiger en l'air... Paris: Claude de Montr'oeil, $1599 . \quad$ Disponível em: <http://gallica.bnf.fr/ark:/12148/bpt6k882581s/f7.image>. Acesso em: 05 out. 2016.

VACCARI, Eduardo. O processo de ingestão e síntese na construção do personagem Pai Ubu. Dissertação (Mestrado em Teatro) - Universidade Federal do Estado do Rio de Janeiro, Rio de Janeiro, 2008.

VAN AELBROUCK, Jean-Philippe. Dictionnaire des danseurs, chorégraphes et maîtres de danse à Bruxelles, de 1600 à 1830. [Bruxelles]: Conseil de la musique de la Communauté française de Belgique; Liège: Mardaga, 1994.

VIANA, Fausto Roberto Poço. O figurino teatral e as renovações do século XX. São Paulo: Estação da Letras e Cores, 2010.

VIANA, Fausto Roberto Poço; CAMPELLO NETO, Antonio Heráclito C. Introdução histórica sobre cenografia: os primeiros rascunhos. São Paulo: Fausto Viana, 2010.

WEBER, Susan; AMES, Kenneth L.; WITTMANN, Matthew. The american circus. New York: Bard Graduate Center: Decorative Arts, Design History, Material Culture; New Haven; London: Yale University Press, 2012. 


\section{ANEXO 1 - FICHAS TÉCNICAS}

\section{NAU DE ÍCAROS}

Elenco: Alex Marinho, Erica Stoppel, Fernando Sampaio, Juliana Neves, Lincoln Rollim, Marco Vettore, Patrícia Horta, Vera Abbud e Paola Musatti

Produção e concepção: Companhia Cênica Nau de Ícaros

Direção: Sérgio Coelho

Assistente de Direção: Marco Vettore

Sonoplastia: Cia. Cênica Nau de Ícaros

Operador de Som: Edgar Bustamante

Iluminação: Domingos Montagner e Marcos Carrera

Operador de Luz: Marcos Carrera

Cenografia: Rafael Rocha

Figurino: Adriana Vaz Ramos

Adereços: Erika Verzutti

Designer Gráfico: Carlos Lopes Nunes

Fotos: Rafael Assef

O espetáculo Nau de Ícaros estreou em maio de 1993 na lona do Circo Escola Picadeiro e em abril de 1994 foi adaptado para palco italiano e fez temporada de 6 meses nos teatros João Caetano, Paulo Eiró e Artur de Azevedo, na cidade de São Paulo.

\section{O PALLÁCIO NÃO ACORDA}

Direção: Leopoldo Pacheco

Assistente de Direção: Marco Vettore

Produção: Cia. Cênica Nau de Ícaros

Roteiro: Naum Alves de Souza 
Texto: Paulo Rogério Lopes

Produção Executiva e Direção de Produção: Marília Vasconcelos e Guga Pacheco

Cenário: Rafael Campos Rocha

Adereços: Beto de Souza e Inês Sakay

Figurino: Adriana Vaz Ramos

Iluminação: Wagner Freire

Trilha Musical: Zero Freitas

Coreógrafa: Lara Pinheiro

Operador de Luz: Sylvie Laila

Operador de Som: Janice Rodrigues

Programação Visual: Carlos Lopes Nunes

Fotografia: Marcelo Soubhia

Imagens em Vídeo: Raimo Benedetti

Diretor de Palco: Fábio Espósito, Juliano Dias e Álvaro Barcellos

Elenco: Alex Marinho, Ana Luiza Leão, Erica Stoppel, Fernando Sampaio, Patricia Horta, Erica Rodrigues, Marco Vettore e Juliana Neves

O espetáculo $O$ pallácio não acorda estreou em 10 de maio de 1997, no Teatro Paulo Eiró, na cidade de São Paulo.

\section{QUASE UMA}

Direção e Argumento: Marco Vettore

Elenco: Alex Marinho, Ana Luiza Leão, Bruno Duarte, Lenis Pereira, Cristina

Oliveira, Inaê Lucatto, Denis Duarte, Maurici Brasil, Érica Faria, Leandro Medina, João Paulo Simão, Francisco Simão, Letícia Doretto, Lilian Nakassu, Luciana Orsi, Flávia Maia, Marília de Zita, Lourdes Mianda, Nenê Lucatto, Jesum Biasin, Sandra Cajá e Luz Morena

Direção de Palco: Álvaro Barcellos

Videoasta: Raimo Benedeti 
Assistente de Vídeo: Celso Reeks

Músicas: Bloco do BAQUE BOLADO

Cenografia: Luz Morena

Iluminação e Figurinos: Marco Vettore

Produção e Administração: Álvaro Barcellos e Gabi

O espetáculo Quase uma... estreou em maio de 1998 no Galpão Nau de Ícaros, na cidade de São Paulo.

\section{O CASAMENTO DE LINA}

Concepção e Direção Geral: Marco Vettore

Produção: Álvaro Barcellos

Engenharia circense: Alex Marinho

Imagens: Raimo Benedetti

Elenco: Alvaro Barcellos, Alex Marinho, Ana Luiza Leão, Celso Reeks, Érica Rodrigues, David Reeks, Denis Duarte

Contrarregras: Leonardo Galo, Juca Dias Zé

Figurino: Marco Vettore

Produção Geral: Companhia Cênica Nau de Ícaros

O espetáculo $O$ casamento de Lina estreou em 11 de dezembro de 1999 no Sesc Pompéia, na cidade de São Paulo.

\section{EL GRAN CIRCO CARNAVAL}

Concepção do espetáculo: Marco Vettore

Direção e trilha sonora: Marco Vettore

Elenco: Álvaro Barcellos, Beatriz Evrard, Celso Reeks, Érica Rodrigues, Leticia Doretto, Marco Vettore 
Músicos: Desde a concepção até o presente momento, muitos músicos foram convidados, dentre eles: Bruno Duarte, Lenis Pereira, Cristina Oliveira, Inaê Lucatto, Denis Duarte, Maurici Brasil, Leandro Medina, João Paulo Simão, Francisco Simão, Lilian Nakassu, Luciana Orsi, Flávia Maia, Marília de Zita, Lourdes Mianda, Nenê Lucatto, Jesum Biasin, Sandra Cajá e Luz Morena

Técnico: Paulo Souza

Figurinos e adereços: Adriana Vaz Ramos

Produção Executiva: Nau de Ícaros

Produção Administrativa: Álvaro Barcellos

O espetáculo El gran circo carnaval estreou em fevereiro de 1999 no Sesc Pompéia, na cidade de São Paulo.

\section{O CIRCO}

Texto: Juliano Dias

Direção e argumento: Marco Vettore

Elenco: Alex Marinho, Álvaro Barcellos, Ana Luiza Leão, Erica Rodrigues, Cesar “Cara” Lopes, Celso Reeks e Luciano Bussab

Engenharia Circense: Alex Marinho

Música: Éder “o” Rocha

Trilha Sonora: Raimo Benedetti

Figurinos: Leopoldo Pacheco

Iluminação: Marcos Carreira

Técnico de Som: Alexis

O espetáculo $O$ circo estreou em janeiro de 2000 no Teatro do Shopping SP Zona Sul, na cidade de São Paulo.

\section{ANIMAACÃO}

Direção e Argumento: Marco Vettore

Coreografia e Preparação em Nova Dança: Adriana Grechi 
Direção Musical: Éder "o" Rocha

Figurinos: Adriana Vaz Ramos

Vídeos: Sérgio Roizemblit

Projeto de Luz: Wagner Freire

Movimento para Cena: Maria Thais

Cenografia: Luciano Bussab

Elenco: Alex Marinho, Ana Luiza Leão, Erica Rodrigues, Álvaro Barcellos, Letícia Doretto, Cesar Lopes, Celso Reeks e Luciano Bussab

Produção: Cia. Cênica Nau de Ícaros

Produção Executiva: Rafael Cortez, Jun, Sérgio Andrade e Amanda Felício

O espetáculo AnimaAção estreou em abril de 2001 no Galpão Nau de Ícaros, na cidade de São Paulo.

\section{NAUHUMORICOS}

Texto: Paulo Rogério Lopes

Criação: Cia. Cênica Nau de Ícaros

Direção: Marco Vettore

Elenco: Alex Marinho, Ana Luiza Leão, Erica Rodrigues, Álvaro Barcellos, Letícia Doretto, Cesar Lopes, Celso Reeks e Luciano Bussab

Cenografia e Engenharia Circense: Luciano Bussab

Figurinos: Companhia Cênica Nau de Ícaros

Produção Executiva: Companhia Cênica Nau de Ícaros

Produção: Companhia Cênica Nau de Ícaros

O espetáculo NauHumoricos estreou em 23 de julho de 2000 na $8^{\text {a }}$ edição da Mostra de Teatro Monte Azul, na cidade de São Paulo. 


\section{E AGORA...}

Texto: Paulo Rogério Lopes

Criação: Cia. Cênica Nau de Ícaros

Direção: Marco Vettore

Elenco: Álvaro Barcellos, Beatriz Evrard, Celso Reeks, Erica Rodrigues, Luciano Bussab, Letícia Doretto, Marco Vettore e Patricia Rizzi

Cenografia: Luciano Bussab

Figurinos: Companhia Cênica Nau de Ícaros

Produção Executiva: Companhia Cênica Nau de Ícaros

Produção: Companhia Cênica Nau de Ícaros

O espetáculo E agora... estreou em outubro de 2002 no Centro Cultural do Banco Real, na cidade de São Paulo.

\section{FRONTEIRAS}

Direção: Marco Vettore

Autoria: Paulo Rogério Lopes e Marco Vettore

Coautores e Intérpretes: Álvaro Barcellos, Beatriz Evrard, Celso Reeks, Erica Rodrigues, Luciano Bussab, Letícia Doretto, Marco Vettore e Patricia Rizzi

Colaboração Coreográfica: Dani Lima, Adriana Grechi

Preparação de Atores: Melissa Vettore

Preparadores Técnicos: Adriana Grechi (dança), César Lopes (circo), Dani Lima (dança e circo), Diogo Granato (contato improvisação), Érica Stoppel (lira), Letícia Doretto (danças brasileiras), Pedrinho Salustiano (cavalo marinho), Marcelo "Chocos" (kung fu), Melissa Vettore (teatro) e Erica Rodrigues (dança)

Cenários e coord. técnica de equipamentos de circo: Luciano Bussab

Figurinos e Maquiagens: Adriana Vaz Ramos

Projeto de iluminação: Gian Bortolotti 
Vídeos: Gabi Greeb, Arthur Lescher, Raimo Benedetti e Marco Vettore

O espetáculo Fronteiras estreou em 6 de novembro de 2002 na $3^{\text {a }}$ Bienal Sesc de Dança, na unidade do Sesc, em Santos, SP.

\section{CIDADE DOS SONHOS}

Texto: Fábio Malavoglia

Argumento: Juliano Dias e Marco Vettore

Direção: Leopoldo Pacheco

Assistência de Direção: Marco Vettore

Figurinos: Adriana Vaz Ramos

Cenografia: Luciano Bussab

Engenharia Circense: Luciano Bussab

Iluminação: Nau de Ícaros

Produção Executiva: Álvaro Barcellos

Elenco: Álvaro Barcellos, Beatriz Evrard, Erica Rodrigues, Celso Reeks, Jéssica Arpin, Letícia Doretto, Luciano Bussab, Patrícia Rizzi

O espetáculo Cidade dos sonhos estreou em 24 de abril de 2004 no Centro Cultural São Paulo, na Sala Jardel Filho, na cidade de São Paulo.

\section{DE UM LUGAR PARA O OUTRO}

Roteiro e Direção: José Possi Neto

Coreografia: Miriam Druwe

Intérpretes-criadores: Álvaro Barcellos, Beatriz Evrard, Celso Reeks, Erica Rodrigues, Letícia Doretto, Marco Vettore

Intérprete Convidada: Fernanda Gusso

Cenografia e Figurinos: Marco Lima

Iluminação: Wagner Freire 
Vídeos: Estúdio Bijari

Trilha Sonora: André Hosoi e Bruno Buarque

Músicos Convidados: Barbatuques, Ricardo Valverde, Samba, Lenis Rino e Denis

Duarte

Estúdio de Gravação: YB Studio

Engenheiro de Som: Gustavo Lenza

Design Gráfico: li3.ch

Diagramação: Celso Reeks

Ilustração e Tipografia: True

Foto de Arte: Chris Von Ameln

Coordenação Técnica de Cenas e Estruturas de Circo: Marco Vettore

Colaboração de Pesquisa: Graziela Rodrigues

Preparação em Dança Contemporânea: Miriam Druwe

Preparação em Danças Brasileiras: Letícia Doretto

Preparação Física: Liceu da Cultura Física

Acupunturista: Dr. Ling Tung Yang

Aderecistas: Naná Lavander, Nani Brisque, Verônica Árias, Marcelo Andrade

Costureiras: Benê Calistro, Célia Calistro, Zezé de Castro

Terno "Viajante": Dona Zenaide Lobão

Camareira: Gisele Pereira

Contrarregra: Newton Saiki

Auxiliar de Montagem: Agilson Avelino (Tico)

Operador de Luz: Paulo Souza

Operador de Som e Vídeo: Beto de Faria

Fotos de Divulgação: Chris Von Ameln e Danielle Sandrini

O espetáculo De um lugar para o outro estreou em 10 de março 2007 no Sesc Pinheiros, na cidade de São Paulo. 


\section{TIRANDO OS PÉS DO CHÃO}

Direção: Erica Rodrigues

Codireção:Marco Vettore

Coreografia: Erica Rodrigues

Intérpretes-criadores: Álvaro Barcellos, Beatriz Evrard, Celso Reeks, Erica Rodrigues, Letícia Doretto, Marco Vettore

Assistência de Direção: Julia Santos

Coordenação de Figurinos: Leopoldo Pacheco

Locução Myrna: Marcelo Várzea

Iluminação: Wagner Freire

Fotos: Chris Von Ameln; Valéria Grzywacz; Henrique Lenza; Caio Castor

Supervisão das entrevistas: Roberta Kovac

Dança contemporânea: Miriam Druwe

Workshop "O corpo em cena”: Flavia Pucci

Coordenação de Produção: Ricardo Muniz Fernandes

Preparação Física: Márcia Francine

Produção Executiva: Roberto Haathner

Administração Geral: Álvaro Barcellos

Coordenação Geral: Marco Vettore

Realização: SESC São Paulo - Consolação

O espetáculo Tirando os pés do chão estreou em 9 junho de 2010 no Teatro Anchieta, no Sesc Consolação, na cidade de São Paulo.

\section{MENOR QUE O MUNDO}

Texto: Leonardo Moreira / Carlos Drummond de Andrade

Direção: Leonardo Moreira

Cenário: Marisa Bentivegna 
Figurino: Chris Aizner

Iluminação: Wagner Freire

Trilha Sonora: Marcelo Pelegrini

Fotografia: Chris vonAmeln

Produção e Administração: Cia. Cênica Nau de Ícaros / Bel Gomes

Realização: Sesi-SP

Elenco: Alvaro Barcellos, Beatriz Evrard, Celso Reeks, Erica Rodrigues, Leticia

Doretto, Marco Vettore e Roberto Haathner

O espetáculo Menor que o mundo estreou em 5 de abril de 2012 no Teatro do Sesi, no Centro Cultural Fiesp, na cidade de São Paulo. 


\section{ANEXO 2 - ENTREVISTA TIRANDO OS PÉS DO CHÃO}

Nome e Idade

Profissão - O que você faz hoje, com o que você trabalha? Você sempre trabalhou com isso ou você fazia outra coisa?

Como você resolveu, escolheu essa profissão?

Você teria vontade de fazer outra coisa?

O amor está presente na sua profissão? Como?

Você se lembra como você sentiu o amor a primeira vez na sua vida? Como foi?

Você se lembra da sua primeira experiência amorosa? Como foi? Como você sabia que era amor?

Você acha o amor físico, emocional, racional ou irracional?

Onde você sente o amor fisicamente no seu corpo? É uma sensação boa ou não?

O amor faz a gente perder a cabeça? Ele cega ou esclarece?

Ele te cega em relação ao outro ou em relação a si mesmo?

Nelson coloca que o Amor é eterno. Você concorda? E que o verdadeiro amor só acontece uma vez na vida. Você concorda?

O que te marcou mais o amor ou o desamor?

Ele diz: "Somos todos fantoches: não escolhemos nem certo nem errado, porque simplesmente não escolhemos..." O que você acha?

Outra colocação dele é que não se pode amar e ser feliz ao mesmo tempo. Ele coloca:

"Não lhe basta amar? Você quer ainda por cima ser feliz?"

Como o amor está presente hoje na sua vida em que aspecto da vida ele é mais forte?

O que te tira os pés do chão? 